AFRILEX

\title{
LEXIKOS 9
}

BURO VAN DIE WAT 


\section{Lexikos 9}




\section{Lexikos 9}

Redakteur

Editor

J.C.M.D. du Plessis

Resensieredakteur

Review Editor

T. Harteveld

AFAiLEX African Association for Lexicography

AFRILEX-REEKS 9:1999

AFRILEX SERIES 9:1999

BURO VAN DIE WAT

STELLENBOSCH 


\section{Uitgewer Publisher}

\section{BURO VAN DIE WAT \\ Posbus 245 \\ 7599 STELLENBOSCH}

Kopiereg (C) 1999 deur die uitgewer

Alle regte streng voorbehou

Eerste uitgawe 1999

Tipografie en uitleg

deur Tanja Harteveld

Bandontwerp deur Piet Grobler

Geset in 10 op 12 pt Palatino

Gedruk en gebind deur Rotapress

Stewartstraat 59 Goodwood

ISBN 0958412057

Geen gedeelte van hierdie publikasie mag sonder skriftelike verlof van die uitgewer gereproduseer of in enige vorm of deur enige elektroniese of meganiese middel weergegee word nie, hetsy deur fotokopiëring, plaat- of bandopname, mikroverfilming of enige ander stelsel van inligtingsbewaring

No part of this publication may be reproduced, stored in a retrieval system, or transmitted, in any form or by any means, including electronic, mechanical, photographic, magnetic or other means, without the prior written permission of the publisher

Menings wat in artikels en resensies uitgespreek word, is nie noodwendig dié van AFRILEX of die Buro van die WAT nie

Opinions expressed in the articles and reviews are not necessarily those of AFRILEX or of the Bureau of the WAT 


\title{
Adviesraad / Advisory Board
}

Dr. H. Béjoint (Frankryk/France)

Prof. A. Delbridge (Australië/Australia)

Prof. V. February (Nederland/The Netherlands)

Prof. R.H. Gouws (RSA)

Dr. R.R.K. Hartmann (Groot-Brittanje/Great Britain)

Prof. M.H. Heliel (Egipte/Egypt)

Dr. V. Kukanda (Gaboen/Gabon)

Prof. W. Martin (België en Nederland/Belgium and The Netherlands)

Prof. I.A. Mel'cuk (Kanada/Canada)

Prof. M. Schlaefer (Duitsland/Germany)

Prof. J. Taeldeman (België/Belgium)

Prof. P.G.J. van Sterkenburg (Nederland/The Netherlands)

Prof. H.E. Wiegand (Duitsland/Germany)

Prof. L. Zgusta (VSA/USA)

\section{Redaksiekomitee / Editorial Committee}

\author{
Prof. W.R.G. Branford (RSA) \\ Prof. A. Carstens (RSA) \\ Prof. W.A.M. Carstens (RSA) \\ Dr. H. Chimhundu (Zimbabwe) \\ Dr. A.R. Chuwa (Tanzanië/Tanzania) \\ Prof. C.J. Conradie (RSA) \\ Prof. L.G. de Starler ' (RSA) \\ Prof. J.A. du Plessis (RSA) \\ Dr. A.E. Feinauer (RSA) \\ Prof. E.F. Kotzé (RSA) \\ Dr. M. Lisimba (Gaboen/Gabon) \\ Mev. M. Matthews (RSA) \\ Dr. J.S. Mdee (Tanzanië/Tanzania) \\ Prof. B.M. Mini (RSA) \\ Mnr. M.H. Mpungose (RSA) \\ Prof. F.A. Ponelis (RSA) \\ Prof. D.J. Prinsloo (RSA) \\ Prof. E.H. Raidt (RSA) \\ Mev. P.M. Silva (RSA) \\ Dr. R. Sitaram (RSA) \\ Prof. P.H. Swanepoel (RSA) \\ Dr. J. Tsonope (Botswana) \\ Prof. G.J. van Jaarsveld (RSA) \\ Prof. E.B. van Wyk (RSA)
}




\section{Inhoud / Contents}

Voorwoord

Foreword

J.C.M.D. du Plessis

'n Woord van AFRILEX

xiv

A Few Words from AFRILEX

Danie Prinsloo

Redaksionele doelstellings

$x v i$

Editorial Objectives

xvii

Redaktionelle Ziele

Navorsingsartikel / Research Article

Science through Sepedi: Is Terminologisation a Worthwhile

Venture?

Adelia Carstens

\section{Beskouende artikels / Contemplative Articles}

Terminology in South Africa

Mariëtta Alberts

Die mikrostrukturele bewerking van affikse in Afrikaanse

vertalende woordeboeke

Gerda de Wet

Lost in a Labyrinth of Lexicography — Labours of a Lawyer

Marthie Jansen

Functionele aspecten van de gecomputeriseerde lexicografie Joost Kist

Translating Culture in Bilinguai Dictionaries 
Access Structures in a Standard Translation Dictionary

Phillip Adriaan Louw

Dictionaries and the Standardisation of Spelling in Swahili

James S. Mdee

Kriteria vir 'n Afrikaanse aanleerderwoordeboek

Anna Nel Otto

\section{Projekte / Projects}

The Macquarie Dictionary, its History and its Editorial Practices Arthur Delbridge and Susan Butler

Towards a Multilingual Dictionary of Academic Words Julia Read and Marguerite Ambrose

\section{Leksikovaria / Lexicovaria}

The Importance of a Business Plan when Planning a Lexicographical Project Mariëtta Alberts

Planning and Management - the Most Neglected Activities 198 in Lexicography D.J. van Schalkwyk

\section{Meetings / Byeenkomste}

Lexicography in a Multilingual South Africa

The National Lexicography Units - Existing and Prospective M.B. Kumalo

Bureau of the Woordeboek van die Afrikaanse Taal

B.P.D. Gabriels, A.E. Cloete and W.F. Botha

Dictionary Unit for isiNdebele

P.B. Skhosana

Dictionary Unit for South African English 
Sepedi Dictionary Project

D.J. Prinsloo and K.J. Mashamaite

Xhosa Dictionary Project

T.X. Mfaxa

Zulu Dictionary Project

A.C. Nkabinde

The State of Lexicography in Sesotho

M.A. Moleleki

The State of Lexicography in Setswana

M.R. Malope

The State of siSwati Lexicography

P.M. Lubisi

The State of Tshivenda Lexicography

A. Mawela

The State of Xitsonga Lexicography

254

D.I. Mathumba

\section{Resensieartikels / Review Articles}

Afrikaanse Spreekwoorde en Uitdrukkings: 'n makrostrukturele

beskouing

Chrisna Beuke-Muir

Situating A Dictionary of South African English on Historical Principles within a More Comprehensive Lexicographic Process

Rufus H. Gouws

Portals to Knowledge: CD-ROM Encyclopaedias, with Specific

Reference to Microsoft Encarta 99 Encyclopedia

Phillip Adriaan Louw 


\section{Resensies / Reviews}

Joyce M. Hawkins (Compiler). The South African Oxford School

Dictionary

Nigel Bakker

Nasionale Terminologiediens van die Departement van Kuns,

Kultuur, Wetenskap en Tegnologie. Drukkerswoordeboek /

Printing Dictionary

Nolan N. Kearns

P.R. Subramanian (Chief Editor). Kriyāvin Tarkälat Tamil Akaräti

(Tamil-Tamil-Ankilam) (Dictionary of Contemporary Tamil

(Tamil-Tamil-English))

G. Murugan

P.R. Subramanian (Chief Editor). Tarkälat Tamil Maraputtotar

Akarati (Tamil-Tamil-Ankilam) (Dictionary of Idioms and Phrases in Contemporary Tamil (Tamil-Tamil-English))
G. Murugan

Frans van Niekerk, Joey Basson en Kobus Grobler (Samestel-

lers). Wilde Woordeboek
A.F. Prinsloo

Dictionary of Grammar

E. Ridge

T. McArthur and I. Kernerman (Editors). Lexicography in Asia Rambhajun Sitaram

\section{Publikasieaankondigings / Publication Announcements}

Voorskrifte aan Skrywers

Instructions to Authors

Richtlinien für Autoren 


\section{Voorwoord}

Die leksikografiese gemeenskap van Afrika is vanuit die Weste en die Ooste met die internasionale gemeenskap verbind. Behalwe die ryk verskeidenheid inheemse tale word baie Westerse en Oosterse tale ook in die meeste Afrikalande gepraat. Hierdie verskeidenheid word weerspieël in hierdie nommer van Lexikos.

Naasmekaarbestaande veeltalige gemeenskappe het 'n opwindende en stimulerende invloed op mekaar. Vir 'n aansienlike tyd was dit byvoorbeeld die geval in die Republiek van Suid-Afrika. Sedert die erkenning van elf amptelike tale in die grondwet van die land, het 'n gemeenskap gedurende die afgelope paar jaar ontwikkel waar elke taal meer bewus geword het van die ryk erfenis van die ander tale.

Die doel van die instelling van die Pan-Suid-Afrikaanse Taalraad (PANSAT) is die ontwikkeling en bevordering, nie net van die elf amptelike tale nie, maar ook van die baie ander tale wat in Suid-Afrika gepraat word. Een van die take wat aan PANSAT opgedra is, is die totstandbrenging van die leksikografie-eenhede vir elke amptelike taal. Om hierdie rede word 'n artikel geplaas wat die Wet bespreek waardeur PANSAT ingestel is en wat die bepalings vir die leksikografie-eenhede uiteensit, asook PANSAT se verantwoordelikhede betreffende die totstandbrenging van die leksikografie-eenhede. Daar is ook twee artikels oor die beplanning en bestuur van leksikografie-eenhede.

'n Oorsig van die leksikografiese situasie in die Republiek van Suid-Afrika word gegee in 'n spesiale afdeling wat handel oor die missie, geskiedenis en huidige omstandighede van die reeds bestaande leksikografie-eenhede, asook van tale waarvoor leksikografie-eenhede tot stand gebring gaan word.

Die uitdagings en moontlikhede van veeltaligheid word ondersoek in 'n artikel oor 'n veeltalige woordeboek van akademiese woorde. In verdere bydraes word die wenslikheid van die ontwikkeling van 'n tegniese woordeskat vir die Afrikatale oorweeg. Ander skrywers bespreek probleme wat verband hou met die vertaling van woorde en uitdrukkings uit tale wat tot ander kulture behoort. Die besondere eienskappe van aanleerderswoordeboeke, veral aanleerderswoordeboeke van ander kulture, word ondersoek.

Die invloed van inheemse en ander tale op die Engels wat in 'n bepaalde land gepraat word, word aangeraak in twee artikels oor woordeboeke wat variëteite van Engels bevat, Suid-Afrikaanse Engels en Australiese Engels. 


\section{Dankbetuiging}

Sonder bydraers sal Lexikos nie moontlik wees nie, en hulle moet bedank word, nie alleen vir hul bydraes nie, maar ook vir die hulp om hul bydraes te finaliseer. Net so kan sonder die keurders van die artikels gehalte nie gewaarborg word nie. Hul kommentaar het dikwels gelei tot belangrike verbeterings en byvoegings deur die bydraers tot hul artikels. Die keurders moet bedank word vir die aandag wat hulle aan die evaluering van die artikels gegee het.

Die lede van die afdeling Redaksionele Steundienste van die Buro van die Woordeboek van die Afrikaanse Taal het 'n groot aandeel in die verskynirig van hierdie nommer van Lexikos gehad. Mnr. Etienne Botha het gehelp met die redigering van die meeste van die artikels, en benewens om as resensieredakteur op te tree, was me. Tanja Harteveld verantwoordelik nie alleen vir die administrasie en korrespondensie nie, maar ook vir die elektroniese setwerk. Hul bekwame en professionele bydrae word hoog gewaardeer.

J.C.M.D. du Plessis

Buro van die Woordeboek van die Afrikaanse Taal 


\section{Foreword}

The African lexicographic community is joined to the international lexicographic community from the West and the East. In addition to the rich variety of indigenous languages in most African countries, many Western and Eastern languages are also spoken. This diversity is reflected in this edition of Lexikos.

Coexisting multilingual societies have an exiting and stimulating influence on each other. This has been the case for some time in for example the Republic of South Africa. Since the recognition of eleven official languages in the new constitution of this country, a community has developed over the past few years where each language has become more aware of the rich heritage of other languages.

The purpose of the formation of the Pan South African Language Board (PANSALB) is the development and advancement not only of the eleven official languages, but also of the many other languages spoken in South Africa. One of the tasks PANSALB has been charged with is the establishment of lexicography units for each official language. For this reason a paper is included discussing the Act by which PANSALB was formed and setting out the regulations for lexicography units, as well as PANSALB's responsibilities regarding the establishment of the lexicography units. There are also two articles on the planning and management of lexicography units.

In a special section dealing with the mission, history and present state of existing lexicography units as well as of languages for which lexicography units are to be established, an overview of the lexicographic situation in the Republic of South Africa is given.

The challenges and possibilities of multilingualism are explored in an article on a multilingual dictionary of academic words. In further contributions, the feasibility of developing a technical vocabulary for African languages is considered. Other authors discuss problems associated with the translation of words and expressions from languages which belong to other cultures. The particular qualities of learner's dictionaries, especially of learner's dictionaries for students from different cultures, are examined.

The influence of indigenous and other languages on English as spoken in a particular country is touched on in two articles on dictionaries containing varieties of English, South African English and Australian English. 


\section{Acknowledgements}

Without the contributors, Lexikos would not be possible, and they must be thanked not only for their contributions, but also for helping to finalise their articles. Similarly, without the judges of articles, quality could not be guaranteed. Their comments often led to important improvements and additions by the contributors to their articles. The judges must be thanked for the attention paid to the evaluation of articles.

The members of the Editorial Support Services division of the Bureau of the Woordeboek van die Afrikaanse Taal had a large share in the appearance of this edition of Lexikos. Mr Etienne Botha assisted in editing most of the articles, and in addition to acting as review editor, Ms Tanja Harteveld was also responsible not only for the administration and correspondence, but also for the electronic typesetting. Their efficient and professional contribution is much appreciated.

J.C.M.D. du Plessis

Bureau of the Woordeboek van die Afrikaanse Taal 


\section{'n Woord van AFRILEX}

Die African Association for Lexicography (AFRILEX) het vanjaar sy vierde internasionale kongres gehou en kyk met trots en dankbaarheid terug na vier jaar waarin die vereniging gegroei en sy regmatige plek ingeneem het tussen die ander leksikografieverenigings in die wêreld, organisasies soos EURALEX, AUSTRALEX, ASIALEX en die DSNA. Hierdie organisasies het AFRILEX met ope arms verwelkom en deurlopende skakeling en die uitruiling van korrespondensie vind plaas. Dit is grootliks te danke aan die doelgerigte leiding deur Rufus Gouws en harde werk deur lede van die bestuur asook entoesiastiese ondersteuning deur lede van die vereniging.

AFRILEX streef daarna om aktief betrokke te wees by alle aspekte van leksikografie hetsy prakties of teoreties. AFRILEX onderneem opleidingsinisiatiewe en ondersteun aksies wat korpusbou en die ontwikkeling van rekenaarprogramme ten doel het. Binne Suid-Afrika speel die vereniging ' $n$ groot rol ten opsigte van woordeboekmaak vir die Afrikatale en die vestiging van woordeboekeenhede vir dié tale. Gevolglik word AFRILEX gereeld geraadpleeg en staan individue en organisasies met raad en daad by.

AFRILEX is verder trots daarop om Lexikos as mondstuk te hê, 'n tydskrif wat plaaslik en internasionaal erken word, en AFRILEX moedig graag lede aan om artikels voor te lê vir publikasie. AFRILEX kon tot dusver daarin slaag om jaarliks 'n eksemplaar van Lexikos gratis aan lede te versend, en die bereidwilligheid van die Buro van die WAT om die kostes so laag as moontlik te hou word hoog waardeer.

Daar word gepoog om lede deur middel van omsendbriewe en nuusbriewe voortdurend op hoogte van die vereniging se aktiwiteite te hou asook deur middel van die tuisblad:

www.up.ac.za/academic/libarts/afrilang/homelex.html

Hierdie uitgawe van Lexikos bied weer eens puik leesstof aan lede asook aan andere wat belang het by woordeboekmaak en woordeboekgebruik.

Danie Prinsloo

Voorsitter: AFRILEX 


\section{A Few Words from AFRILEX}

The African Association for Lexicography (AFRILEX) held its fourth international conference this year and looks back with pride and gratitude to four years during which the association has grown and taken its rightful place among the other lexicography associations of the world, organisations such as EURALEX, AUSTRALEX, ASIALEX and the DSNA. AFRILEX has enjoyed a hearty welcome from these associations and liaises, as well as exchanges correspondence with them regularly. This is to a large extent to be attributed to Rufus Gouws's purposeful leadership and to the hard work done by members of the management committee, as well as to the enthusiastic support of the members of the association.

AFRILEX strives to be actively involved in all aspects of lexicography, whether practical or theoretical. AFRILEX undertakes training initiatives and supports actions aimed at corpus creation and the development of computer programs. Inside South Africa the organisation also plays a major role in respect of dictionary compilation for the African languages and in the establishment of dictionary units for these languages. As a result AFRILEX is consulted on a regular basis and supports individuals and organisations with advice and assistance.

AFRILEX furthermore takes pride in having as its mouthpiece Lexikos, a journal which is recognised both locally and internationally, and AFRILEX likes to encourage its members to submit articles for publication. To date AFRILEX has managed to send members a copy of Lexikos annually free of charge, and the willingness of the Bureau of the WAT to keep costs at a minimum level is highly appreciated.

The association attempts to keep members informed about activities by means of circulars and newsletters as well as through the website:

www.up.ac.za/academic/libarts/afrilang/homelex.html

This issue of Lexikos once again offers excellent reading matter to its members and to those interested in dictionary compilation and dictionary use.

Danie Prinsloo

Chairperson: AFRILEX 


\section{Redaksionele doelstellings}

Lexikos is 'n tydskrif vir die leksikografiese vakspesialis en word in die AFRILEX-reeks uitgegee. "AFRILEX" is ' $n$ akroniem vir "leksikografie in en vir Afrika". Van die sesde uitgawe af dien Lexikos as die amptelike mondstuk van die African Association for Lexicography (AFRILEX), onder meer omdat die Buro van die WAT juis die uitgesproke doel met die uitgee van die AFRILEX-reeks gehad het om die stigting van so 'n leksikografiese vereniging vir Afrika te bevorder.

Die strewe van die AFRILEX-reeks is:

(1) om 'n kommunikasiekanaal vir die nasionale en internasionale leksikografiese gesprek te skep, en in die besonder die leksikografie in Afrika met sy ryk taleverskeidenheid te dien;

(2) om die gesprek tussen leksikograwe onderling en tussen leksikograwe en taalkundiges te stimuleer;

(3) om kontak met plaaslike en buitelandse leksikografiese projekte te bewerkstellig en te bevorder;

(4) om die interdissiplinêre aard van die leksikografie, wat ook terreine soos die taalkunde, algemene taalwetenskap, leksikologie, rekenaarwetenskap, bestuurskunde, e.d. betrek, onder die algemene aandag te bring;

(5) om beter samewerking op alle terreine van die leksikografie moontlik te maak en te koördineer, en

(6) om die doelstellings van die African Association for Lexicography (AFRILEX) te bevorder.

Hierdie strewe van die AFRILEX-reeks sal deur die volgende gedien word:

(1) Bydraes tot die leksikografiese gesprek word in die vaktydskrif Lexikos in die AFRILEX-reeks gepubliseer.

(2) Monografiese en ander studies op hierdie terrein verskyn as afsonderlike publikasies in die AFRILEX-reeks.

(3) Slegs bydraes wat streng vakgerig is en wat oor die suiwer leksikografie of die raakvlak tussen die leksikografie en ander verwante terreine handel, sal vir opname in die AFRILEX-reeks kwalifiseer.

(4) Die wetenskaplike standaard van die bydraes sal gewaarborg word deur hulle aan 'n komitee van vakspesialiste van hoë akademiese aansien voor te lê vir anonieme keuring.

Lexikos sal jaarliks verskyn, terwyl verdienstelike monografiese studies sporadies en onder hulle eie titels in die AFRILEX-reeks uitgegee sal word. 


\section{Editorial Objectives}

Lexikos is a journal for the lexicographic specialist and is published in the AFRILEX Series. "AFRILEX" is an acronym for "lexicography in and for Africa". From the sixth issue, Lexikos serves as the official mouthpiece of the African Association for Lexicography (AFRILEX), amongst other reasons because the Bureau of the WAT had the express aim of promoting the establishment of such a lexicographic association for Africa with the publication of the AFRILEX Series.

The objectives of the AFRILEX Series are:

(1) to create a vehicle for national and international discussion of lexicography, and in particular to serve lexicography in Africa with its rich variety of languages;

(2) to stimulate discourse between lexicographers as well as between lexicographers and linguists;

(3) to establish and promote contact with local and foreign lexicographic projects;

(4) to focus general attention on the interdisciplinary nature of lexicography, which also involves fields such as linguistics, general linguistics, lexicology, computer science, management, etc.;

(5) to further and coordinate cooperation in all fields of lexicography; and

(6) to promote the aims of the African Association for Lexicography (AFRILEX).

These objectives of the AFRILEX Series will be served by the following:

(1) Contributions to the lexicographic discussion will be published in the specialist journal Lexikos in the AFRILEX Series.

(2) Monographic and other studies in this field will appear as separate publications in the AFRILEX Series.

(3) Only subject-related contributions will qualify for publication in the AFRILEX Series. They can deal with pure lexicography or with the intersection between lexicography and other related fields.

(4) Contributions are judged anonymously by a panel of highly-rated experts to guarantee their academic standard.

Lexikos will be published annually, but meritorious monographic studies will appear as separate publications in the AFRILEX Series. 


\section{Redaktionelle Ziele}

Lexikos ist eine Zeitschrift für Fachleute der Lexikographie, die in der AFRILEX-Serie erscheint. "AFRILEX" ist ein Akronym für "Lexikographie in und für Afrika". Von der sechsten Ausgabe dient Lexikos als amtliches Mundstück des African Association for Lexicography (AFRILEX), u.a. weil das Büro des WAT gerade das ausgesprochene Ziel mit der Ausgabe der AFRILEX-Serie hatte, die Gründung solches lexikographischen Vereins für Afrika zu fördern.

Die folgenden Ziele werden mit den Publikationen der AFRILEX-Serie verfolgt: Man möchte:

(1) ein Medium schaffen für die nationale und internationale Diskussion, besonders aber der Lexikographie in Afrika mit seinen zahlreichen Sprachen dienen;

(2) die Diskussion fördern, unter Lexikographen als auch zwischen Lexikographen und Linguisten;

(3) Kontakt herstellen und fördern zwischen südafrikanischen und ausländischen lexikographischen Projekten;

(4) die Aufmerksamkeit lenken auf die interdisziplinäre wissenschaftliche Praxis der Lexikographie, die Beziehung aufweist zur Linguistik, allgemeinen Sprachwissenschaft, Lexikologie, Computerwissenschaft, zum Management und zu anderen Bereichen;

(5) die Zusammenarbeit auf allen Gebieten der Lexikographie fördern und koordinieren;

(6) die Ziele der African Association for Lexicography (AFRILEX) fördern.

Gemäß den Zielsetzungen der AFRILEX-Serie werden:

(1) Beiträge zum lexikographischen Gespräch in der Fachzeitschrift Lexikos veröffentlicht;

(2) monographische und andere Studien auf diesem Gebiet als getrennte Publikationen in der AFRILEX-Serie erscheinen;

(3) nur einschlägige Beiträge, die sich ausschließlich mit Lexikographie oder mit fachverwandten Gebieten befassen, für Aufnahme in der AFRILEXSerie in Betracht gezogen;

(4) Beiträge anonym von einem aus Spezialisten des Faches von hohem akademischen Ansehen bestehenden Ausschuß beurteilt.

Lexikos erscheint jährlich. Ausgewählte monographische Studien dagegen erscheinen gelegentlich als getrennte Publikationen in der AFRILEX-Serie. 


\title{
Science through Sepedi: Is Terminologisation a Worthwhile Venture?*
}

\author{
Adelia Carstens, Department of Afrikaans, \\ University of Pretoria, Pretoria, Republic of South Africa
}

\begin{abstract}
The terminologisation of the African languages has been hotly debated for more than a decade, yet little progress has been made in devising strategies to guide this process. The following are among the indicators that the time is ripe to realise the ideal of terminologisation: the lack of success thus far achieved in facilitating scientific knowledge through non-mother-tongue education; the existence of a noteworthy stock of technical terms in the African languages; and the positive attitudes of educators towards the use of the mother tongue, especially in rural areas. These indicators are backed up by statistics on pass rates for Physical Science in the Northem Province; the results of an attitude/opinion survey among teachers of Science in this region; lexical data obtained from an empirical survey as well as from an independent source. The results of the research seem to validate terminologisation of Sepedi from an educational point of view. It is, however, realised that the attitudes and perceptions of other stakeholders such as pupils and parents need to be taken into account when recommendations are made with regard to sensitive issues such as terminologisation and the language of scientific communication.
\end{abstract}

Keywords: AFRICAN LANGUAGES, LANGUAGE DEVELOPMENT, LANGUAGE FOR SPECIAL PURPOSES, MOTHER-TONGUE EDUCATION, MULTILINGUALISM, NORTHERN SOTHO, PHYSICAL SCIENCE, SCIENTIFIC LANGUAGE, SEPEDI, TERMINOGRAPHY, TERMINOLOGISATION, TERMINOLOGY

Opsomming: Wetenskap in Sepedi: Is terminologisering die moeite werd? Die terminologisering van die Afrikatale word al vir langer as 'n dekade druk bespreek. Tog is weinig vordering nog gemaak met betrekking tot die beplanning van algemene strategieë wat rigting aan hierdie proses kan gee. Daar is veral drie aanwysers dat die tyd ryp is om erns te maak met terminologisering: die min sukses wat tot dusver behaal is in die fasilitering van wetenskaplike kennis deur medium van niemoedertaalonderrig; die bestaan van 'n noemenswaardige korpus tegniese/wetenskaplike terme in die Afrikatale; en die positiewe gesindheid van wetenskaponderwysers teenoor die gebruik van die moedertaal, veral in landelike gebiede. Ter ondersteuning van hierdie aanduidings word die volgende getuienis aangebied: statistiek oor die slaagsyfers vir Natuurwetenskap in die Noordelike Provinsie, die uitslae van 'n houdingstudie / meningspeiling

A shortened version of this article was read as a paper at the Third International Conference of the African Association for Lexicography, held at the Potchefstroom University for Christian Higher Education, Potchefstroom, 29 June-1 July 1998. 
onder wetenskaponderwysers in hierdie gebied; leksikale gegewens wat sowel uit 'n empiriese ondersoek as van 'n onafhanklike bron verkry is. Vanuit ' $n$ opvoedkundige oogpunt blyk die resultate van die navorsing die terminologisering van Sepedi te staaf. Daar word egter besef dat die houdings en persepsies van ander rolspelers, bv. leerlinge en ouers, in berekening gebring moet word wanneer aanbevelings gemaak word oor sensitiewe kwessies soos die taal van wetenskapskommunikasie.

Sleutelwoorde: AFRIKATALE, MOEDERTAALONDERRIG, MEERTALIGHEID, NOORDSOTHO, NATUURWETENSKAP, SEPEDI, TAALONTWIKKELING, TAAL VIR SPESIALE DOELEINDES, TERMINOLOGIE, TERMINOGRAFIE, TERMINOLOGISERING, WETENSKAPSTAAL

\section{Introduction}

Terminologisation of the African languages has been hotly debated for more than a decade and numerous workshops, conferences, academic publications and seminars have been devoted to this topic or aspects thereof (cf. Cluver 1987, 1989; Matšela 1987; LANGTAG Subcommittee on the Development of (South) African Languages 1996; National Terminology Services 1997). Questions such as the following have been asked:

\section{(a) What are the aims of terminologisation in the African languages?}

In the terminologisation debate objectives and motivations such as the following have featured:

- functional elaboration, which will allow a speaker of any official South African language to use his/her language effectively in any context (Cluver 1989);

- full empowerment through the language which a speaker knows best (Ngubane 1997: 7);

- providing access to knowledge and allowing concept-formation in the language the speaker knows best (Mthembu 1997: 99);

- providing the opportunity to exercise democratic language rights (Ngubane 1997: 7-8);

- the compilation of technical defining dictionaries for each of the school subjects offered in the mother tongue at primary school level (Cluver 1996: 10); and

- facilitating mother-tongue education up to secondary and tertiary level (cf. Prah 1995, 1997; Mohapi 1997: 75; and Mthembu 1997: 99 who express their support, vs. Bekeweni 1997: 94 who expresses scepticism over the feasibility thereof in terms of the time and cost involved). 
Although these objectives can be separated, they overlap to a certain extent: common to them all is the ideal of "elevating" the African languages to the same functional level as English and Afrikaans, i.e. providing these languages and their speakers with the same opportunities and bestowing them with the same privileges that Afrikaans and English had enjoyed until 1994.

Should terminologisation reach a specific stage before the language(s) in question can be used as fully-fledged special languages for purposes such as instruction, publication, evaluation, etc.? Is it possible to address highly specialised topics such as nuclear physics, biochemistry, etc. in a language with no standardised (formally recorded) LSP for that subject field?

In metaphorical terms these two questions (cf. Carstens 1997: 6; Matšela 1987: 80; Bekeweni 1997: 94) may be rephrased as different philosophies serving as prerequisites for the use of a particular language as a scientific or technical language:

- All the necessary tools must be in place before construction can begin.

- Use what you have. That which you lack, can be borrowed or adapted along the way.

(c) Does terminologisation of the African languages form an integral part of the Government's language development programme?

The promotion of Science, Engineering and Technology (SET) is clearly one of the primary objectives of the present South African Government. These areas are characterised in the Green Paper on Science and Technology (s.a.) as the "absolutely vital components of economic and social progress". Access to these domains, as to most other domains in life, is provided through language, and if the linguistic code employed denies access rather than facilitates it, knowledge remains exclusive to the historically privileged. This fact is clearly realised by Government. In his opening address at a workshop entitled "The Feasibility of Technical Language Development in the African Languages" held in Pretoria on 8 March 1996, the Minister of Arts, Culture, Science and Technology, Dr B.S. Ngubane, made the following statement indicating the Government's recognition of the need for language development and the role it may play in the process of empowerment:

The vision we have for our country and the strategies to arrive at our goals depend on many factors, one of them being appropriate knowledge. Knowledge is power. Knowledge transfer can only take place if a person understands the concepts being conveyed to him or her and the context in which it takes place. Keeping in mind that people are a nation's greatest asset, development can only be fostered if people are 
developed. In this whole process, language plays the most important role (Ngubane 1997: 7).

A logical entailment of these words seems to be that if a person does not have full command of the language in which a concept is conveyed to him or her, conceptualisation will not be (fully) realised. However, the usefulness of the African languages in scientific and academic contexts is often articulated in rather tentative terms by Government spokespersons, i.e. without identifying personally with the particular goal. In an ensuing statement made by the above speaker, he expresses himself as follows:

It has been argued (my italics) that the development of South Africa first requires the development of the literacy of the people in their own mother tongues, which will assist them in developing skills in scientific and technical fields.

Although I strongly agree with Chumbow (1990: 65) that "all languages are capable of being developed (sufficiently rapidly) by the expansion of vocabulary to cope with any aspect of knowledge, including science and technology", there are still many South Africans who have to be convinced of this fact. For many, only hard scientific evidence will be recognised as the gunshot signifying the start of the race towards terminologisation.

The primary aim of this paper is then to indicate, on the basis of empirical research, that the development of the African languages as special languages for the full spectrum of scientific and technological disciplines is indeed feasible and advisable for the following reasons:

- the lack of success thus far achieved in facilitating scientific knowledge through non-mother-tongue education;

- the stock of technical terms that already exist in the African languages; and

- the positive attitude of educators regarding selective multilingualism (including the use of the mother tongue) in the classroom.

\section{Statistics on pass rates in Science}

The following statistics, obtained from the Department of Education of the Northern Province, provide alarming evidence regarding the matric results in Physical Science for 1996 and 1997. Among other tendencies indicated by the figures below (Manyane 1998: 10-13), they also indicate that the failure rate is much higher in schools where Science is not taught in the mother tongue ${ }^{1}$ (i.e. where English is used as the medium of instruction to teach Science to mothertongue speakers of Sepedi), than in schools where the medium of instruction corresponds with the mother tongue of the pupils: 


\section{NORTHERN PROVINCE, REGION 1 (WESTERN) AREA 2 (MAHWELERENG)}

$\begin{array}{lll} & 1996 & 1997 \\ \text { Number of schools: } & 34 \text { (2 Afrikaans, 32 Sepedi) } & 29 \text { (2 Afrikaans, 39 Sepedi) }\end{array}$

TABLE 1: Pass rates, Mahwelereng (Higher Grade and Standard Grade)

\begin{tabular}{|c|c|c|c|c|}
\hline Year & Level & $\begin{array}{c}\text { Total number of } \\
\text { candidates }\end{array}$ & $\begin{array}{c}\text { Number of candidates } \\
\text { passed }\end{array}$ & Percentage \\
\hline 1996 & HG & 420 & 75 & 17,9 \\
\hline & SG & 444 & 154 & 34,7 \\
\hline 1997 & HG & 382 & 169 & 44,2 \\
\hline & SG & 720 & 299 & 41,5 \\
\hline
\end{tabular}

TABLE 2: Symbols achieved for Physical Science in Mahwelereng (Higher Grade)

\begin{tabular}{|c|c|c|c|c|}
\hline Symbol & \multicolumn{2}{|c|}{$\begin{array}{c}\text { Number of candidates } \\
\text { (language of instruction: Afrikaans) } \\
\text { (mother tongue: Afrikaans) }\end{array}$} & $\begin{array}{c}\text { Number of candidates } \\
\text { (language of instruction: English) } \\
\text { (mother tongue: Sepedi) }\end{array}$ \\
\hline & 1996 & 1997 & 1996 & 1997 \\
\hline A & 1 & 3 & 0 & 0 \\
\hline B & 6 & 5 & 0 & 0 \\
\hline C & 13 & 22 & 2 & 1 \\
\hline D & 14 & 12 & 7 & 8 \\
\hline E & 8 & 18 & 24 & 26 \\
\hline
\end{tabular}

TABLE 3: Symbols achieved for Physical Science in Mahwelereng (Standard Grade)

\begin{tabular}{|c|c|c|c|c|}
\hline Symbol & \multicolumn{2}{|c|}{$\begin{array}{c}\text { Number of candidates } \\
\text { (language of instruction: Afrikaans) } \\
\text { (mother tongue: Afrikaans) }\end{array}$} & \multicolumn{2}{|c|}{$\begin{array}{c}\text { Number of candidates } \\
\text { (language of instruction: English) } \\
\text { (mother tongue: Sepedi) }\end{array}$} \\
\hline A & 0 & 0 & 0 & 1 \\
\hline B & 4 & 2 & 1 & 1 \\
\hline C & 8 & 11 & 7 & 4 \\
\hline D & 9 & 12 & 28 & 27 \\
\hline E & 14 & 11 & 39 & 70 \\
\hline
\end{tabular}




\section{AREA 3 (WARMBATHS)}

$\begin{array}{lll} & 1996 & 1997 \\ \text { Number of schools: } & 11 \text { (4 Afrikaans, 7 Sepedi) } & \text { (3 Afrikaans, 8 Sepedi) }\end{array}$

TABLE 4: Pass rates, Warmbaths (Higher Grade and Standard Grade)

\begin{tabular}{|c|c|c|c|c|}
\hline Year & Level & $\begin{array}{c}\text { Total number of } \\
\text { candidates }\end{array}$ & $\begin{array}{c}\text { Number of candi- } \\
\text { dates passed }\end{array}$ & Percentage \\
\hline 1996 & HG & 314 & 126 & 40,1 \\
\hline & SG & 157 & 131 & 83,4 \\
\hline 1997 & HG & 192 & 108 & 56,3 \\
\hline & SG & 242 & 127 & 52,5 \\
\hline
\end{tabular}

TABLE 5: Symbols achieved for Physical Science in Warmbaths (Higher Grade)

\begin{tabular}{|c|c|c|c|c|}
\hline Symbol & \multicolumn{2}{|c|}{$\begin{array}{c}\text { Number of candidates } \\
\text { (language of instruction: Afrikaans) } \\
\text { (mother tongue: Afrikaans) }\end{array}$} & $\begin{array}{c}\text { Number of candidates } \\
\text { (language of instruction: English) } \\
\text { (mother tongue: Sepedi) }\end{array}$ \\
\hline A & 1996 & 1997 & 1996 & 1997 \\
\hline B & 8 & 8 & 0 & 0 \\
\hline C & 9 & 6 & 1 & 1 \\
\hline D & 37 & 31 & 5 & 5 \\
\hline E & 31 & 17 & 2 & 10 \\
\hline
\end{tabular}

TABLE 6: Symbols achieved for Physical Science in Warmbaths (Standard Grade)

\begin{tabular}{|c|c|c|c|c|}
\hline Symbol & $\begin{array}{r}\text { Number of candidates } \\
\text { (language of instruction: Afrikaans) } \\
\text { (mother tongue: Afrikaans) }\end{array}$ & \multicolumn{2}{|c|}{$\begin{array}{c}\text { Number of candidates } \\
\text { (language of instruction: English) } \\
\text { (mother tongue: Sepedi) }\end{array}$} \\
\hline & 1996 & 1997 & 1996 & 1997 \\
\hline A & 5 & 0 & 0 & 0 \\
\hline B & 3 & 6 & 4 & 1 \\
\hline C & 16 & 11 & 7 & 7 \\
\hline D & 30 & 30 & 12 & 14 \\
\hline E & 21 & 17 & 12 & 12 \\
\hline
\end{tabular}


Despite the changes in the various figures for Higher and Standard Grade that occurred from 1996 to 1997, the average for Physical Science remains below $50 \%$, and the students who had received mother-tongue education still achieved much higher symbols than those who had received non-mothertongue education. Although one cannot necessarily assign a causal relationship between medium of instruction and academic achievement (other variables may be inadequately trained teachers, low school attendance figures and lack of equipment) the correlation across different areas does merit research with regard to the use of language in the classroom and the possible impact this may have on conceptualisation. The research results may then indicate a course of action with regard to the development of languages and academic resources in South Africa.

\section{Sepedi as an LSP for Science: evidence from a survey among secon- dary school teachers}

During the course of 1997 I conducted a terminology research project in the Northern Province together with a Masters Degree student, Ms S.M. Manyane. Our main objectives were to establish :

(a) the status and frequency of Sepedi as an LSP for Science in this area;

(b) the attitudes and perceptions of one category of the role-players in the area, namely teachers of Physical Science;

(c) the scope and nature of the existing corpus of conventionalised and semi-conventionalised Science terms in Sepedi; and

(d) the feasibility of compiling translatory and explanatory tools (in the form of multilingual explanatory special-field dictionaries) in order to provide access to knowledge via the mother tongues of the pupils, as well as through English.

The research questions (focusing on (a)=(c)) were addressed as follows:

\subsection{Status and usage frequency of Sepedi as an LSP for Science}

During 199750 teachers of Science were approached by Ms Manyane at schools in 6 circuits ( 2 areas) of the Northern Province where Sepedi is the mother tongue of the majority of pupils (in $74 \%$ of the cases):

AREA

Warmbaths

\section{CIRCUIT}

Warmbaths

Thabazimbi 
Mahwelereng

$$
\begin{aligned}
& \text { Mahwelereng } \\
& \text { Mokopane } \\
& \text { Mapela } \\
& \text { Potgietersrus }
\end{aligned}
$$

The teachers were requested to fill in a questionnaire on the use of Science terms. This questionnaire was intended to be the first step in determining:
- the current status of Sepedi as an LSP for Science in predominantly Sepe- di-speaking areas, and
- the attitudes and perceptions of speakers regarding the terminologisa- tion of Sepedi, especially for the purpose of conceptualisation.

Each questionnaire was personally collected, and a 100\% response was obtained. This also meant that the sample could be regarded as representative from a geographical point of view. The results can be summarised as follows:

- $\quad 4 \%$ of the Science teachers indicated that they at least sometimes used the mother tongue of the pupils when teaching Science.

- The following reasons were given for occasionally reverting to the mother tongue:

to re-explain a concept which pupils had not understood through English $(96 \%)$,

to explain difficult concepts $(87 \%)$,

when performing experiments $(64 \%)$, and

to explain new concepts $(59 \%)$.

- According to $70 \%$ of the teachers, pupils responded better when mothertongue teaching took place.

- $\quad 76 \%$ of the teachers were of the opinion that pupils understood better when teaching took place in the mother tongue.

- Regarding the use of terminology when reverting to the mother tongue, $34 \%$ answered that they only used English terms; $62 \%$ stated that they used English terms for some concepts and mother-tongue terms for others; and only $2 \%$ indicated that they only used mother-tongue terms.

- There seems to be either uncertainty or indecisiveness among teachers regarding the deliberate coining of terms in the mother tongue: only $36 \%$ were in favour of term creation across the board; $52 \%$ were of the opinion that translation equivalents should only be created for some concepts; and 12\% said they would prefer that only English terms be used.

- Two thirds of the teachers $(66 \%)$ were of the opinion that pupils would prefer to be taught Science only in the mother tongue; $26 \%$ said that it would not matter to the pupils; and only $8 \%$ expressed the view that the pupils would reject mother-tongue teaching. 
- Concerning the teachers' attitudes towards monolingual mother-tongue teaching of Science, $36 \%$ were strongly in favour of mother-tongue teaching of Science; $42 \%$ were in favour of transferring the responsibility - in particular to the pupils $(14 \%)$; the parents $(30 \%)$; or the principal $(8 \%)$. Only $12 \%$ were strongly opposed to mother-tongue teaching of Science.

- A comparable response was received on the question relating to teachers' attitudes towards the option of pupils being formally evaluated in the mother tongue: $34 \%$ reacted strongly positive; $30 \%$ cautiously positive; and $36 \%$ were opposed to any change from the status quo.

Although the majority of teachers admit that the use of the mother tongue plays a significant role in the teaching of Science, especially in concept-formation and understanding, and express fairly positive feelings towards mother-tongue teaching and learning, they are hesitant to unconditionally support terminologisation in the mother tongue. Holistically interpreted, the results suggest that the hesitation might be due to the fact that empowerment through English as well as international participation are valued extremely highly, and that monolingual mother-tongue teaching or evaluation might jeopardise the freedom only recently won after apartheid.

These attitudes seem to correlate with attitudes in higher education circles, although the views of the latter are expressed in a more covert way. In the FRD's annual magazine Scientech (1998: 3), an article "Places for Children's Minds to Play", dealing with the work of the Setlhare Science Curriculum Trust (a body based at the University of the Witwatersrand and concerned with the development of materials and methods for the teaching and learning of Science), confirms my observation that educators demonstrate a growing openness towards alternative teaching models. The contribution closes with the following summary of research done by the Curriculum Trust:

The study did not attempt to analyse the relationship between the students' multilingual dialogues and their learning of science. But it did suggest that there was a need for research to investigate the dominant assumption that science can and should be learnt in English only.

It does however seem as if there is caution not to allow language to become the central issue. Although language is perceived to be an important aspect of all teaching, the approach is pragmatic: facilitating understanding through the language the student knows best, but promoting proficiency and communication skills in the language of wider communication. This seems to be the view expressed in another article published in the same edition of Scientech (1998: 1011), entitled "Practical Solutions for Today's Classrooms". The article describes a project initiated by a team of microbiologists from the University of Cape Town to develop a theoretical and practical training course for secondary school Biology teachers. After a very successful pilot course offered in 1997, the project 
team planned to publish a Biology teachers' practical handbook in which the teaching approach and methodologies tested in the course were expounded. As far as the approach to language is concerned, the writer of the Scientech article says: "The book is also sensitive to the fact that teachers and students may speak many languages and that learners need to reach understanding in their first language and express this in the dominant classroom language."

An important question to ask is, however, whether a lenient approach towards language of instruction and classroom language will be acceptable to parents and pupils. Evidence described in paragraph 4 below is not favourable in this regard.

\subsection{Existing corpus of Science terms in Sepedi}

In order to find an empirically justified answer to the research question on the scope and nature of the existing corpus of Science terms in Sepedi, it was decided to compile a second questionnaire containing the Science terms in the glossaries of the English text books for Physical Science (Grades 11 and 12). Twenty respondents from the Warmbaths and Mahwelereng areas of the Northern Province, each with more than five years experience of teaching Science, were requested to supply translation equivalents in Sepedi.

The translation equivalents ${ }^{2}$ supplied by the respondents may be grouped into roughly four categories: indigenous, morphologically simplex or complex translation equivalents; transliterations; possessive constructions (containing two nouns combined by the possessive conjunctions $w a, b a, y a, l a, a, s a t 5 a, b j a$ or $g a$, often used to translate English or Afrikaans compounds); and longer circumlocutions.

\section{(a) Indigenous equivalents}

Only the following indigenous equivalents (morphologically simplex or complex) were supplied ( 30 out of $240=12 \%$ )

ENGLISH
absolute zero
acceleration
addition reaction
alkanol (alcohol)
allotrope
analyser
antinode
balanced forces
bond energy

\section{SEPEDI}

lefeelafeela

koketšlebelo

tlhakantšhophetogo

setagi

thlagontši

sentšhadikarolwana

makopanelo-lephotong

"maatlatekatekanyo"

maatlatomagano 


$\begin{array}{ll}\text { catalyst } & \text { setlhotlholetši } \\ \text { current } & \text { "mohlagase } \\ \text { distance } & \text { bokgole } \\ \text { dynamics } & \text { "diphetogo } \\ \text { energy } & \text { maatla } \\ \text { force } & \text { maatla (dikgoka) } \\ \text { frequency (of force) } & \text { "kgafetšakgafetsa } \\ \text { gradient } & \text { motheosa } \\ \text { half reaction } & \text { seripaphetogo } \\ \text { indication } & \text { sebontšhi / sešupi } \\ \text { inert } & \text { seganaphetogo } \\ \text { kinetic energy } & \text { maatlamosepelo } \\ \text { mass } & \text { boima } \\ \text { period } & \text { nako } \\ \text { phase } & \text { seemo } \\ \text { photon } & \text { lehlasedi } \\ \text { principle } & \text { mokgwa } \\ \text { speed } & \text { lebelo } \\ \text { wave } & \text { lephoto }\end{array}$

\section{(b) Transliterations}

Transliterations were much fewer than expected (only 10 out of $240=4 \%$ ):

ENGLISH
alkanes
alkenes
alkynes
atom
base
electron
halo-alkane
hydro-carbon
hydrogen
ion

SEPEDI
alekane
alekenes
alekaines
atomo
beisi (motheo, botlase)
eleketerone
halo-alikane
haedro-khabone
haedrogene/hydrogene
ayone

The low percentage of transliterations may be ascribed to the following:

- Science teachers may in general not be sensitive to language issues and may not always realise when they are making phonological adaptations.

- The English terms in the original English list are mostly multiword terms or compounds consisting of more than two morphemes. It is to be expected that these complexes will be translated by circumlocutions or 
hybrid circumlocutions (containing Sepedi elements as well as English elements or transliterations), e.g. esiti ya Arrhenius (Arrhenius acid); boima bja atomo (atomic mass).

A list of Sepedi terms compiled independently by a Science teacher in the Northern Province supports this hypothesis (see paragraph 4 below), as his corpus contains more transliterations, e.g.:

\begin{tabular}{ll} 
ENGLISH & SEPEDI \\
acid & esiti \\
aluminium & aluminiamo \\
anion & anayone \\
base & peisi \\
carbon & khabone \\
carbonate & khabonate \\
carbonic & khaboniki \\
cation & katayone \\
chemical & sekhemise (khemikale) \\
chemistry & khemistiri \\
compound & kompo \\
copper & koporo \\
electron & elektrono \\
element & elemente \\
gas & gase \\
hydrogen & hydrogene \\
ion & ayone \\
molecule & molekule \\
oxygen & oksegene \\
proton & protono \\
silver & silibere \\
sodium & sodiamo \\
temperature & themperetsha \\
tin & thine \\
vector & fektoro \\
& \\
\hline &
\end{tabular}

Transliteration as a mechanism for term-formation brings to the fore a deeprooted philosophical controversy. This difference of opinion centers around the need to make international information accessible (in a non-international language) in the most "internationalised" form, versus preserving the language and keeping it pure (cf. French and King 1997: 89; Cluver 1997: 110). 


\section{(c) Possessive constructions}

Possessive phrases, consisting of two nouns combined by a possessive conjunction, were found to be quite prolific, e.g.:

ENGLISH
absorption spectrum
alkali metal
Arrhenius acid
Arrhenius base
atomic mass
atomic number
Balmer series
Boyle's law
cell potential
clock reaction
conservation of energy
crystallography
Dalton's law
Fraunhofer lines
gravitation
Hund's rule
Huygen's principle
hydrogen bond
interference
Le Chatelier's principle
mass number
octet rule
Ohm's law
phase equilibrium
refraction
terminal velocity
wave length

\author{
SEPEDI \\ nweletso ya mebala \\ tšhipi ya alkali \\ esiti ya Arrhenius \\ beisi ya Arrhenius \\ boima bja atomo \\ palo ya a tomo \\ tatelano ya Balmer \\ molao wa Boyle \\ maatla a lelahla \\ tiragalo ya nako \\ polokego ya maatla \\ thuto ya momagano \\ molao wa Dalton \\ methaladi ya Fraunhofer \\ maatlakgogedi a lefase \\ molao wa Hund \\ mokgwa wa Huygen \\ tomagano ya hydrogen \\ thulano ya maphoto \\ mokgwa wa Chatelier \\ nomoro ya boima (palo ya boima) \\ molao wa seswai \\ molao wa Ohm \\ tekatekanyo ya seemo \\ kobego ya mahlasedi \\ lebelo la bofelo \\ botelele bja lephoto
}

Despite the instruction to respondents (by Carstens and Manyane) not to supply meanings instead of translation equivalents, many verbose translations were given. This may either imply that teachers tend to circumvent the lack of terminology by using circumlocutions or that circumlocutions are often used with the deliberate purpose of explaining the meaning of an opaque English term during a Science lesson. Compare the following examples: 


$\begin{array}{ll}\text { ENGLISH } & \text { SEPEDI } \\ \text { capillarity } & \begin{array}{l}\text { go hlatloga goba go theoga ga meetse ka gare ga peipi } \\ \text { a dirwa ke kgogedi magareng ga meetse le peipi } \\ \text { taetšo ya couper ya go laetsa dikarolwana tsa atomo } \\ \text { tša go sepetsa mothagase } \\ \text { phetogo yeo e lego gore maatla a yona a gogwa gore } \\ \text { phetogo e tšwelele pele }\end{array}\end{array}$

Significantly fewer circumlocutions occur in the list compiled by Pare (paragraph 4). This may indicate that the compiler was aware of the requirements for term status (a measure of conventionality, length restriction, etc.), or that he relied on the translation equivalents found in dictionaries and other normative sources, along with those supplied by pupils at his request.

\section{The work of P.T. Pare and F. Ntake}

\subsection{Background}

In the discussion of the research done by Manyane and Carstens I referred to terms collected by P.T. Pare. Pare (personal correspondence by e-mail) taught Science in English to Std. 5 (Grade 7) pupils from 1985 to 1993. During this time he realised that the "lack of involvement in class discussions was due to insufficient command of the language of instruction" and that he was using much of the time in Science classes trying to explain basic English expressions. He also noticed that the results were appalling whenever a descriptive answer was required from pupils during a test or an examination.

From 1991 onwards, he started recording translation equivalents for English terms by consulting his students as well as English-Sepedi and AfrikaansSepedi dictionaries. Only in 1997 did he try to teach bilingually through English and Sepedi to a Std. 2 and a Std. 5 class in St Mark's College at Jane Furse. Together with Fanuel Ntake, a teacher of Physical Science at a secondary school in the Northern Province, he started translating matric examination papers for Chemistry. The reason for this was, among others, to indicate that Sepedi had the terminology necessary to serve as a vehicle for conveying the content of the subject field. The papers in Sepedi (Higher and Standard Grade) translated by Pare and Ntake are currently being reviewed by the Education Department of the Northern Province, and feedback has also been invited from other stakeholders and interest groups.

Pare is convinced that the pupils respond much better when he communicates in Sepedi during Science lessons. However, strong resistance has been encountered from parents. According to him (personal communication by email) "they are worried that Science taught through Sepedi is not proper Science". At a secondary school in Marishani in the Northern Province, where he taught Science to matric pupils, even his fellow teachers and the school princi- 
pal were against his teaching in Sepedi, and put considerable pressure on him to use English only in the classroom. Resistance also came from the parents. Pare expressed their attitude as follows:

Parents generally feel that a good command of English is so essential for their children's success in the modern world that every opportunity must be used to expose them to English. They are unaware of recent linguistic research which shows that the prior acquisition of advanced cognitive processing skills in the mother tongue actually facilitates the acquisition of the second language.

\subsection{The corpus}

Pare's corpus consists of approximately 500 terms. Not all of them are restricted to the domains of Chemistry and Physics. Some are words with general as well as terminological meanings (polysemic or homonymic words of which one or more meanings are terminological meanings), words belonging to the general academic vocabulary, and mathematical terms. When compared to the data collected by Manyane and myself in the Mahwelereng and Warmbaths areas there seem to be similarities as well as differences. Transliterations make out approximately $15 \%$ of Pare's corpus, which is a much higher percentage than recorded in our survey. Moreover, the number of indigenous equivalents recorded by us seem to be significantly fewer than those recorded by Pare. As suggested above, the higher percentage of simplex and complex indigenous equivalents as well as transliterations in Pare's corpus may be ascribed to a deliberate attempt at secondary term-formation rather than to a detailed explication of meaning. Moreover, Pare seems to be making a serious attempt to adapt Sepedi for use as a fully-fledged LSP for Science so that it can take its place at the same level as English. The teachers interviewed by Manyane in the Mahwelereng and Warmbaths area, on the other hand, seem to use Sepedi to explain or disambiguate English terms and expressions. Circumlocutions would serve the purpose better than terminological equivalents in the mother tongue, and as suggested above, this might be the reason for the proliferation of lengthy "definitions" supplied by respondents instead of terminological equivalents.

\section{Conclusion}

My firm conviction is that the evidence resulting from the attitude survey by Carstens and Manyane, the field work by Manyane, Pare and Ntake's experience with teaching through Sepedi, and Pare's comprehensive term list all signify a clear "go ahead". Educators now seem to be realising the advantages of a 
more flexible language policy in the classroom, and that true democracy is being able to use the language one knows best in all possible contexts. Teachers also seem to agree that a pragmatic approach such as "use what you have" is good for language development.

This does however not mean that more research is superfluous. Additional field work is still necessary to elicit the entire stock of terms for special-field concepts that have already acquired term status in the African languages by virtue of their use, inter alia in the classroom situation. It is also necessary to put Sepedi examination papers to the test. The results then need to be compared to those of pupils of similar potential who have written the corresponding English paper. If the results of those who wrote the Sepedi paper are significantly better, a deliberate attempt should be made to convince students, parents and school principals that mother-tongue teaching of content subjects is a step forward and not backward.

The standardisation of Science terms in Sepedi should be encouraged and accelerated in the meantime by recording existing terms in term banks, publishing them in the form of bi- or multilingual term lists and dictionaries, distributing these in schools, and also requesting feedback from all stakeholders: pupils, parents, teachers and principals. The ideal would be for definitions to be supplied in English as well as in the relevant African languages. This will ensure that the learner who speaks an African language will be able to access knowledge via the language he/she knows best, yet remain in close contact with the language(s) used internationally within scientific and economic domains (i.e. English).

\section{Notes}

1. The hypothesis that language is one of the most important stumbling blocks in gaining access to the natural Sciences is verified by a survey that Kwesi K. Prah undertook in 1992 among university students of Botswana, Namibia, Swaziland, the Western Cape, the Transkei and Lesotho (Prah 1995).

2. Translation equivalents given between brackets are alternatives which have been suggested by a mother-tongue speaker invited to comment on the list.

3. Translation equivalents marked with an asterisk were regarded as either too general in meaning or too non-specific by a mother-tongue speaker invited to comment on the list.

4. According to Sager (1990: 80) secondary term-formation occurs when a new term is created for a known concept, either

(a) as a result of the transfer of knowledge (especially scientific and technological knowledge) to another linguistic community - as in the case of many European and Asian languages, and now also the African languages; or

(b) as a result of revising a terminology or specific terms of that terminology. 


\section{References}

Bekeweni, Z. 1997. Standardisation of the Vernacular. National Terminology Services. 1997: 91-95.

Carstens, A. 1997. The Compilation of a Multilingual, Explanatory Dictionary of Chemistry for South African Students. Lexikos 7: 1-24.

Carstens, A. 1998. On Justifying the Compilation of a Multilingual, Explanatory Dictionary of Chemistry. S.A. Journal of Linguistics 16(1): 1-6.

Chumbow, B.S. 1990. The Place of the Mother Tongue in the National Policy on Education. E.N. Emenanjo (Ed.). 1990. Multilingualism, Minority Languages and Language Policy in Nigeria: 6172. Agbor: Central Books in Collaboration with the Linguistic Association of Nigeria.

Cluver, A.D. de V. 1989. A Manual of Terminography. Pretoria: Human Sciences Research Council.

Cluver, A.D. de V. 1987. A Sociolinguistic Approach to the Study of Technical Languages. Logos 7(2): $13-30$.

Cluver, A.D. de V. 1996. Language Development. LANGTAG Subcommittee on the Development of (South) African Languages. 1996: 1-12.

Cluver, A.D. de V. 1997. Summary. National Terminology Services. 1997: 109-114.

French, E and M. King. 1997. Literacy. National Terminology Services. 1997: 85-89.

Joubert, M. (Managing Ed.). 1998. Places for Children's Minds to Play. Scientech '98: 2-3.

Joubert, M. (Managing Ed.). 1998. Practical Solutions for Today's Classrooms. Scientech '98: 10-11.

LANGTAG Subcommittee on the Development of (South) African Languages. 1996. Issues in Language Development: Focusing on The Future of the Apartheid Language Boards and The Harmonisation and Development of African Languages. Pretoria: Department of Arts, Culture, Science and Technology.

Manyane, S.M. 1998. Die gebruik van wetenskapsterminologie in die senior sekondêre fase. Unpublished mini-dissertation for the M.A. degree (by coursework). Pretoria: University of Pretoria.

Matšela, Z.A. 1987. The Problems of Modernising the Development of Sesotho Scientific/Technical Terminologies. Logos 7(2): 79-88.

Mohapi, T.W.D. 1997. Education in Relation to African Languages. National Terminology Services. 1997: 75-80.

Mthembu, P. 1997. Standardisation of the Vernacular. National Terminology Services. 1997: 97-99.

National Terminology Services. 1997. The Feasibility of Technical Language Development in the African Languages. Papers presented at the Human Sciences Research Council, Pretoria, on 8 March 1996. Pretoria: Department of Arts, Culture, Science and Technology.

Ngubane, B.S. 1997. Opening Address. National Terminology Services. 1997: 7-9.

Prah, Kwesi K. 1995. Mother Tongue for Scientific and Technological Development in Africa. Bonn: German Foundation for International Development Education, Science and Documentation Centre.

Prah, K.K. 1997. The Language Factor in the Scientific and Technological Development of Africa. National Terminology Services. 1997: 21-38.

Sager, J. 1990. A Practical Course in Terminology Processing. Amsterdam: Benjamins.

South African Govemment. s.a. Green Paper on Science and Technology. Pretoria: Government Printer. 


\title{
Terminology in South Africa*
}

\author{
Mariëtta Alberts, National Language Service, Department of Arts, Culture, \\ Science and Technology, Pretoria, Republic of South Africa
}

\begin{abstract}
This article deals with terminology and terminography in South Africa. It gives the different meanings attached to the term terminology and describes points of difference between terminology and terminography. It focuses on the dimensions of terminology, namely the cognitive, linguistic and communicative dimension. Since terminologists need to consult with subject specialists, linguists, language users and mother-tongue speakers during different phases of the terminography process, the role of consultation in terminology work is stressed. Various aspects such as cultural differences that need to be taken care of, are discussed. The current South African terminology and terminography situation regarding terminology work undertaken by the National Language Service is examined. Emphasis is placed on the database system being used and the National Termbank. Terminology training also receives attention.
\end{abstract}

Keywords: TERMINOLOGY, TERMINOGRAPHY, TERMINOLOGIST, TERMINOGRAPHER, COGNITIVE DIMENSION, LINGUISTIC DIMENSION, COMMUNICATIVE DIMENSION, TECHNICAL DICTIONARY, SUBJECT SPECIALIST, SUBJECT FIELD, SUBJECT-ORIENTED, CONCEPT-ORIENTED, LANGUAGE-ORIENTED, STANDARDISATION, PRIMARY TERM FORMATION, SECONDARY TERM FORMATION, LOAN WORDS, BORROWING, TRANSLITERATION, NEOLOGISM, EXTENSION OF MEANING, TOTAL EMBEDDING, TRANSFERENCE

Opsomming: Terminologie in Suid-Afrika. Hierdie artikel handel oor terminologie en terminografie in Suid-Afrika. Dit verskaf die verskillende betekenisse wat aan die term terminologie geheg word en beskryf punte van verskil tussen terminologie en terminografie. Daar word gefokus op die dimensies van terminologie, naamlik die kognitiewe dimensie, die taaldimensie en die kommunikatiewe dimensie. Aangesien terminoloë vakspesialiste, linguiste, taalgebruikers en moedertaalsprekers gedurende verskillende fases van terminologiewerk moet raadpleeg, word die rol van konsultasie in terminologiewerk beklemtoon. Verskeie aspekte waaraan aandag gegee behoort te word, soos kultuurverskille, word bespreek. Die huidige Suid-Afrikaanse terminologieen terminografiesituasie ten opsigte van terminologiewerk wat deur die Nasionale Taaldiens onderneem word, word behandel. Klem word geplaas op die databasisstelsel wat gebruik word en die Nasionale Termbank. Daar word ook aandag gegee aan terminologieopleiding.

Sleutelwoorde: TERMINOLOGIE, TERMINOGRAFIE, TERMINOLOOG, TERMINOGRAAF, KOGNITIEWE DIMENSIE, TAALDIMENSIE, KOMMUNIKATIEWE DIMENSIE, VAKWOORDEBOEK, VAKSPESIALIS, VAKGEBIED, VAKGEORIËNTEERD, KONSEPGEORIËN-

* This paper was presented at the Third International Conference of the African Association for Lexicography, held at the Potchefstroom University for CHE, Potchefstroom, 29-30 July 1998. 
TEERD, TAALGEORIËNTEERD, STANDAARDISASIE, PRIMERE TERMSKEPPING, SEKONDERE TERMSKEPPING, LEENWOORDE, ONTLENING, TRANSLITERASIE, NEOLOGISME, BETEKENISUITBREIDING, ALGEHELE INSLUITING, OORDRAG

\section{Introduction}

Unambiguous communication in all theoretical and applied fields of human activity is essential, especially for the information age. Such communication is only possible if unambiguous terms are established for well-defined concepts and if these terms are known and used accordingly.

Contact between various language groups requires multilingual terminology lists or dictionaries. The South African terminologist working at the Terminology Division, National Language Service of the Department of Arts, Culture, Science and Technology has to supply term equivalents in eleven official languages in order to facilitate local communication. The South African terminologist also deals with international standards and concepts and therefore also needs to facilitate international communication.

Various aspects relating to principles and methods of terminology and terminography will be discussed. A discussion of the South African sociolinguistic situation will put the South African terminology practice into perspective.

\section{Terminology and Terminography}

\subsection{Terminology}

Specialist knowledge is doubling every 5-15 years and most documents consist of $30-80 \%$ of specialist terms (cf. Sonneveld 1997). Terminology is the medium through which knowledge is disseminated. It is therefore essential for meaningful communication not only among subject specialists but also between the subject specialist and the layperson. People of different nationalities and language groups should also be able to communicate effectively. It is therefore essential to document terminology in a systematic way to enable subject specialists, language practitioners and laypeople to communicate by using standardised terminology. Terminographical principles need to be applied skilfully for people to be able to document information on concepts and their related terms. Therefore unified guidelines should be applied to facilitate the exchange of scientific and technical information on various levels of communication.

Terminology is a strategic resource. With its related fields of terminography and lexicography, it has an important role in a multilingual country. Through the use of correct terminology, the effective scientific and technical communication skills of all the citizens of South Africa are developed.

The effective management of terms is essential. Collecting information on concepts may seem superfluous, but a lack of systematic terminology management leads to considerable costs and diminished utility or functionality in the 
long run (cf. Sonneveld 1997). Even though terminological and terminographical activities are not always cost-effective, they are still of invaluable cultural, social, historical, functional, academic and scientific importance.

The concept and practice of terminology is poorly understood and in some cases even unknown. Terminology is the study of the concepts and terms found in special languages (cf. Sonneveld 1997). It is also the field of activity concerned with the collection, recording, documentation, description, processing, systematising, standardising, presentation and dissemination of terms which has a certain coherence by virtue of the fact that the terms belong to specialised areas of usage of one or more languages (Sager 1990: 2, 3). Terminology is therefore the collection of terms systematically naming the coherent system of concepts of a specific subject field, discipline, domain, profession or theme. A terminology would therefore form part of the special language of a particular subject-field. Terminology is concerned with special-field concepts, their definitions and names (Alberts 1990: 102).

In contemporary usage, three meanings of the word "terminology" can be distinguished (Sager 1990: 3; cf. Cluver 1989: 146):

(a) The set of practices and methods used for the collection, description and presentation of terms;

(b) A theory, i.e. the set of premises, arguments and conclusions necessary to explain the relationship between concepts and terms which are fundamental for a coherent terminological activity;

(c) A vocabulary of a special subject field.

According to Sonneveld (1997) terminology is used for

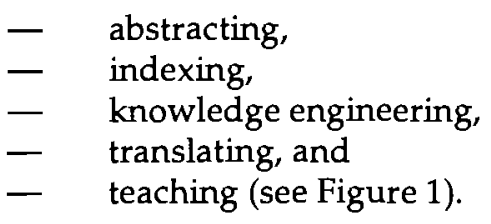

\subsection{Terminography}

Terminography is one of the subdivisions of lexicography and deals with the documentation of the terminology of different subject fields, e.g. technical and scientific terms. The terminology of any subject field (physics, mathematics, biology, chemistry, etc.) or domain (sport, music, etc.) can be documented in terminographical dictionaries, commonly called technical dictionaries.

Terminography can be considered a separate activity from general lexicography. The difference lies in "the different nature of the data traditionally assembled, the different background of the people involved in this work, and to some extent in the different methods used" (Sager 1990: 3). One of the main differences between terminography and lexicography is that terminography is 


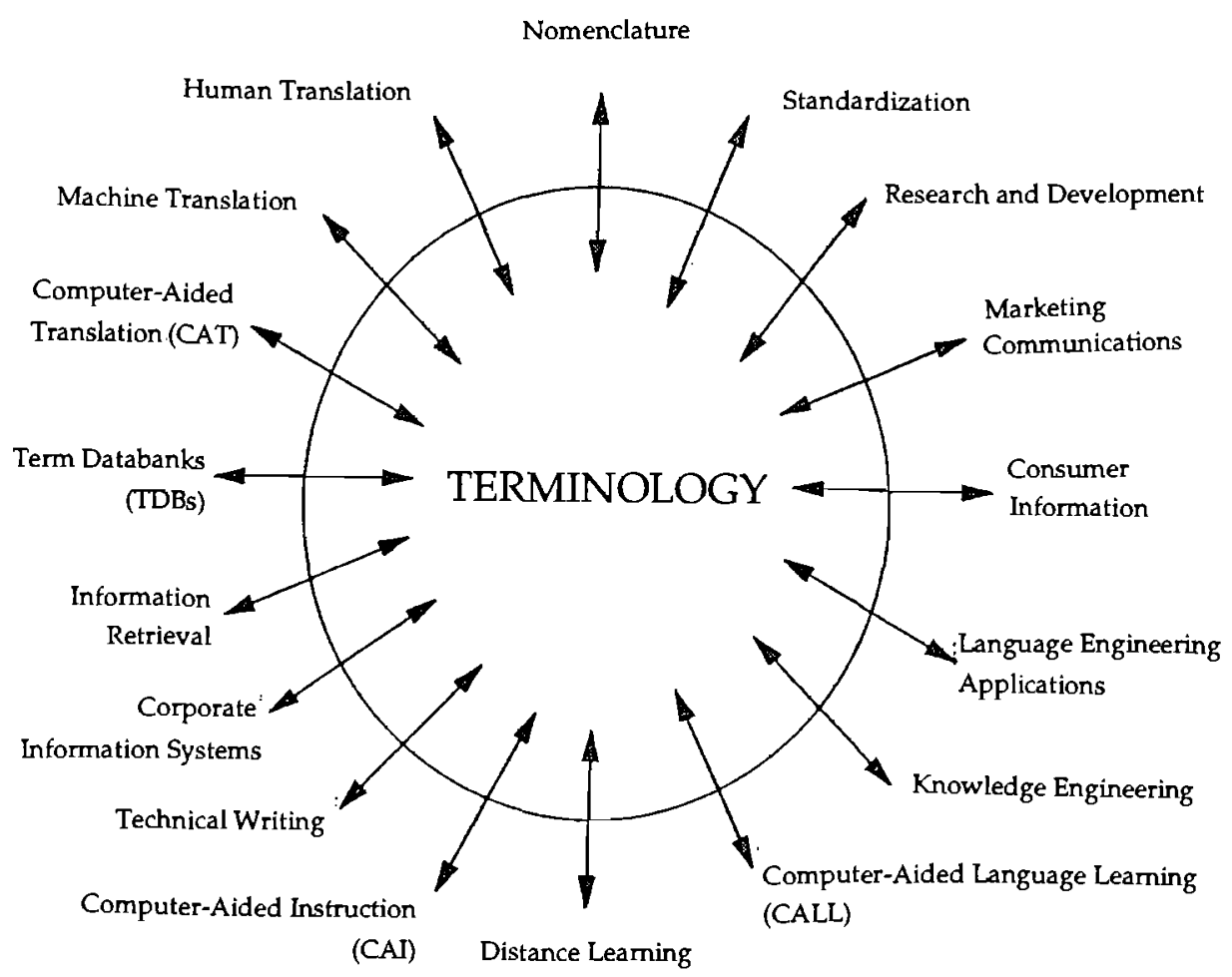

(Cf. Sonneveld 1997)

\section{Figure 1: Terminology}

concept-oriented and general lexicography is more language-oriented. Terminography is only concerned with a very specialised part of the vocabulary of the language of any person, namely scientific and technical terms.

\subsection{Term}

The vocabulary (called terminology) of a subject is the group of words (called terms) that are typically used when discussing or dealing with the specific subject.

Terminological vocabularies are

- based on concepts,

- the result of conceptual analysis, and

- based on relationships between concepts (cf. Sonneveld 1997).

A term is a visual, linguistic representation of a mental concept and can be any of the following: single term, compound word, phrase, collocation, numeral, 
acronym, letter word, abbreviation, chemical symbol, formula, bar-code, icon, mnemonic sign, etc.

The need for unambiguous communication in theoretical and applied fields of human activity is constantly increasing. A terminologist aims to provide unambiguous terms for well-defined concepts. In order to achieve this aim, it is necessary to determine the precise meanings of terms to enable users to comprehend and use them in a universally accepted manner.

Terms can only be used as such if the user already possesses the configuration of knowledge which determines the role of the term in a structured system. A term can be learned contemporaneously with new knowledge, e.g. through text books. However, a term acquired without awareness of the conventional configuration of knowledge to which it relates is communicatively useless. It is possible to codify very strict specifications together with a recommended term, and to seek to achieve agreement on the part of users to use the term with the specified fixed reference. This is then a deliberate attempt to impose uniformity of usage by publicly fixing the relationship between the term and the associated concept and proposing the term as a standard (cf. Sager 1990: 19-20).

Terminology is influenced by the subject fields and areas of activity it serves. The formation of terminology can be regarded as an interdisciplinary activity which is influenced by discoveries, views and developments that occur simultaneously in other areas of knowledge, and different compartmentalisations of knowledge can lead to shifts in the perception of terminology and to changes of terms (cf. Sager 1990: 3-5).
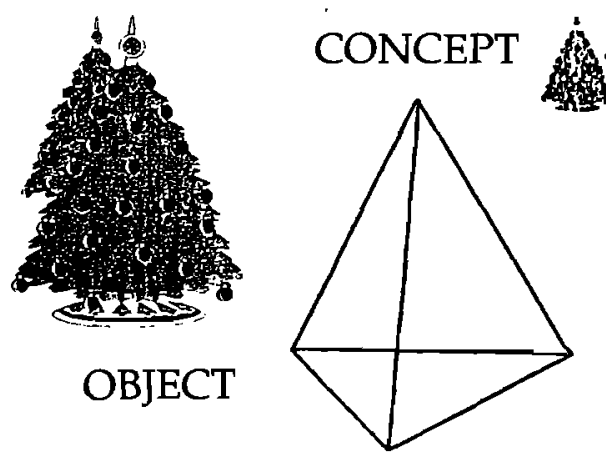

\section{DEFINITION}
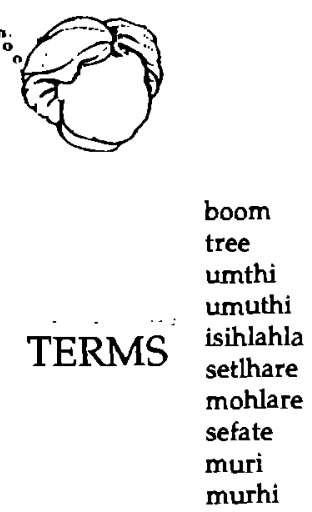

Tall plant with hard, self-supporting trunk and branches, that lives for many years.

Figure 2: Dimensions of terminology: Relation between object, concept, definition and term 


\section{Dimensions of Terminology}

Terminology has at least three dimensions (see Figure 2):

- a cognitive one, which relates the linguistic forms to their conceptual content, i.e. the referents in the real world;

- a linguistic one which examines the existing and potential forms of the representation of terminologies; and

- a communicative one which looks at the use of terminologies, and especially at standardisation processes.

\subsection{The cognitive dimension}

The notion "concept" is central to the theory of terminology, and any terminology activity is preceded by concept formation. Concept formation is a process of variously grouping and ordering the material and immaterial objects which we sense, perceive or imagine into abstract categories. Concepts can therefore be defined as constructs of human cognition processes which assist in the classification of objects by way of systematic or arbitrary abstraction. The naming of a concept is but the first step in the consolidation of a concept as a socially useful or useable entity (Carstens 1997: 7). "In the process of concept formation we group the data of our perception and experience according to common elements which are usually called characteristics," states Sager (1990: 23).

\subsubsection{Terminology work is concept-oriented}

The point of departure in terminology work is the concept and terminology is therefore principally subject- or domain-oriented rather than language-oriented as is the case of general lexicography.

There should be a one-to-one relation between concept and term for exact communication (see Example 1). Terminology is therefore also a standardising process.

$\begin{array}{lll}\text { Concept } & \text { Symbol } & \begin{array}{l}\text { Linguistic Representation } \\ \text { one, een, uno, eins, tee, nngwe, } \\ \text { nngwe, inye, ukunye } \\ \text { two, twee, duo, zwei, pedi, pedi, } \\ \text { bobedi, isibini, isibili }\end{array} \\ & 2, \text { ii, II } & \end{array}$

\section{Example 1}


Exact communication is only possible when there is a one-to-one relation between concept and term. The terminologist describes the concepts of a specific subject field and related domains by means of terms. He/she standardises the concepts and their related terms by defining the concepts.

\subsubsection{The role of definitions}

- A definition (sometimes a simplified or abbreviated definition or expanded context) is supplied to designate the concept.

- It is only through the definition of a concept that one is really in a position to gain enough information on the concept to be able to name such concept or to coin a term.

- Terminologists supply definitions in the source language and in various target languages.

If a concept is defined, its scope is clearly delimited. This can be illustrated with the terms arsonist and pyromaniac (see Example 2).

The terms arsonist and pyromaniac both describe a person who sets fire to an object, but there is a huge difference between them:

An arsonist is a criminal who deliberately sets fire to something, especially a building.

A pyromaniac is a person who cannot control the desire to set fire to things, often because of a mental illness.

\section{Example 2}

\subsubsection{Relations between terms: conceptual cluster in a specific subject field}

The terms of a specific subject field or domain form a conceptual cluster. They act in a specific relation to other terms in the same subject field. Examples of such conceptual clusters are equivalence relations, hierarchical relations (e.g. generic relations, subset relations) and associative relations (cf. Figure 3 ).

The various concepts belonging to a specific subject or domain have to be collected in a systematic way because of their special relation to other terms. It is only by dealing with the various related terms and concepts as a whole that the terminologist can ensure the correct naming of concepts. 


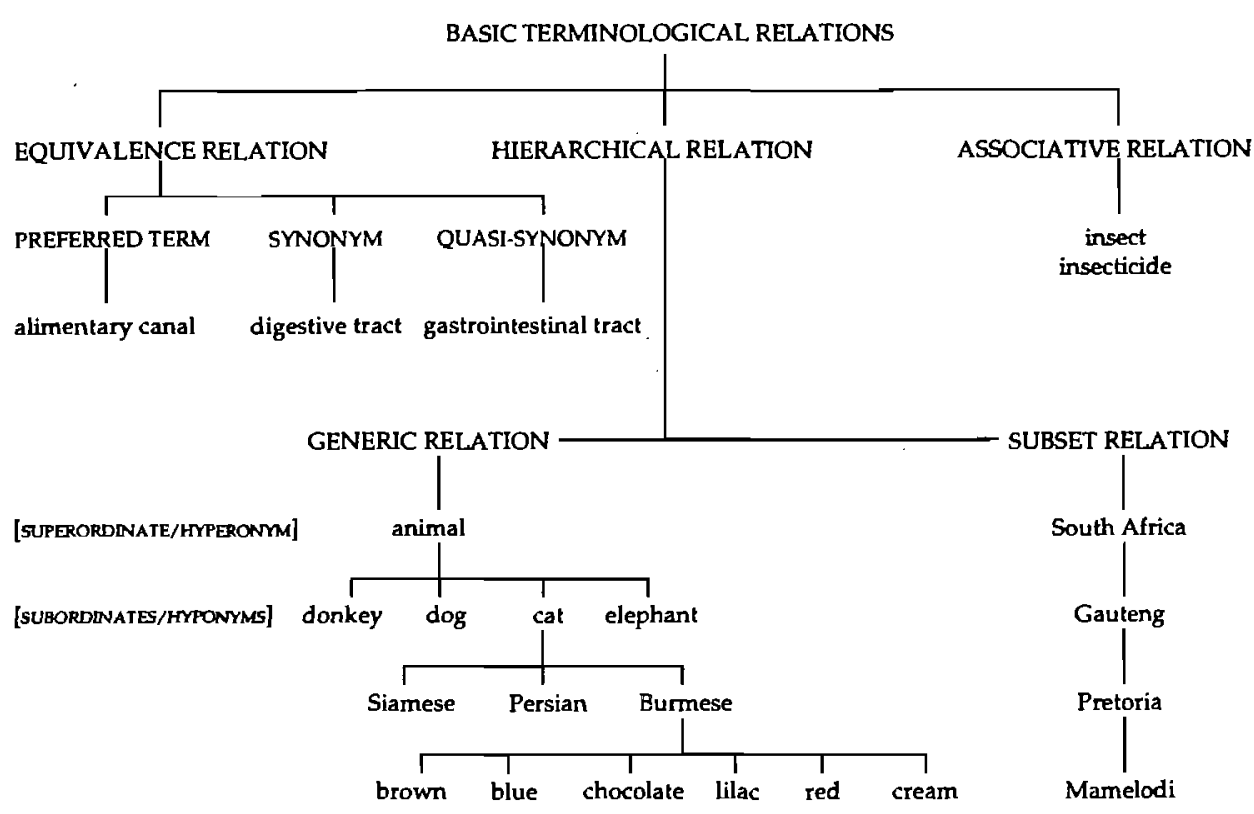

Figure 3: Basic terminological relations

\subsection{The linguistic dimension}

Terms are the linguistic representation of concepts. Most new terms are formed as and when new concepts are created in such instances as new discoveries, the restructuring of existing knowledge, incidental developments or new industrial developments. This type of term formation, termed primary term formation, accompanies concept formation and is monolingual (Sager 1990: 80). The language in which a concept was originally lexicalised is called the documentation language or source language.

One of the major tasks of a terminologist is to establish the terms belonging to a given subject field or domain. The terminologist excerpts the terms from documentation pertaining to a specific subject field and related domains and documents them according to basic terminographical principles.

Secondary term formation occurs when a new term is created for a known concept. It may happen as a result of a revision of terminology or as a result of the transfer of knowledge (especially scientific and technical knowledge) to another linguistic community. Secondary term formation (providing term equiva- 
lents in the target language) is often subject to stricter guidelines than primary term formation and it is the proper concern of terminologists to provide such guidelines on the basis of the term and word formation patterns of the subject field and natural languages in question. Secondary term formation therefore requires of the terminographer a thorough understanding of linguistic mechanisms such as word-formation processes, that are available to him/her to expand the terminology (Cluver 1989: 254, Carstens 1997: 10).

\subsubsection{Source Language vs. Target Language(s)}

In a multilingual society, the terminologist has to document the terms in the source language and has to provide term equivalents in various target languages.

The Terminology Division of the National Language Service (NLS) of the Department of Arts, Culture, Science and Technology is the largest organisation in South Africa conducting terminology work. Other organisations document and create organisation-specific (institutionalised) terminology only, which is often done in co-operation with the NLS, the latter acting in a facilitating and advisory capacity.

The NLS aims to promote multilingualism by supplying terminology in eleven languages in a variety of subject fields. The NLS is developing the various African languages by providing terminology in these languages - thus enhancing literacy in the workplace.

Source language:

- usually English.

Target language(s):

- used to be Afrikaans (because of the previous bilingual policy of the country), but

- now usually the ten other official South African languages (Afrikaans, Sepedi, Sesotho, Setswana, Xitsonga, Tshivenda, isiNdebele, siSwati, isiXhosa, isiZulu) as a result of the multilingual policy of the country, according to an expressed need (stakeholders, collaborators, private sector, etc.).

\subsubsection{Supplying term equivalents}

Term equivalents can inter alia be supplied by means of: 


\section{(a) transliteration}

The classic stem (usually Latin or Greek) is used to coin an equivalent.

silver: $\mathrm{ME}$ from $\mathrm{OE}$ seolfor; akin to OHG silabar, silbar, silver, $\mathrm{ON}$ silfr, Goth silubr - all from a prehistoric Germanic word borrowed from an Asiatic source. Equivalents in South African languages: silver, silwer, silibera, silefera, selefera, isilivere, isiliva.

bail: ME bail, baille, from MF bail, from bailler "to give, deliver", from L bajulare "to bear a burden, keep in custody", from bajulus "porter, load carrier". Equivalents in English, Afrikaans and Sepedi are bail, borg and peile respectively. The source language (English) was used to coin the term equivalent in Sepedi. A $\mathbf{p}$ was used instead of $\mathbf{a} \mathbf{b}$ to get the right pronunciation in Sepedi.

\section{Example 3}

(b) loan words (borrowing)

Borrowing takes place mainly from European languages such as English, Dutch, Flemish, German, French, etc. The principle is to examine the Latin or Greek origin of the term.

affidavit: The term equivalent (e.g. Sepedi equivalent) must be congruent with the word-forming principles of the target language: Latin affidavit, English affidavit, Sepedi afidavite. The ff combination is not normally used in African languages. According to the rule a consonant must be followed by a vowel and one should adhere to the rules of the specific language, therefore: afidavite.

\section{Example 4}

Joseph (1984: 44) distinguishes between two stages of elaboration of the vocabulary of a language:

- an initial period of transference during which heavy borrowing takes place; and

- a nativisation period during which the borrowed elements are changed so that they are incorporated into the indigenous system or are replaced by indigenous terms. 
Transliteration and borrowing develop the language. It should not be regarded as wrong to coin terms according to transliteration or borrowing principles (e.g. book, boek, puku).

\section{(c) total embedding or adoption}

A term is used in its original form without transliteration. The original term usually stems from Latin (in the case of legal or medical terms) or Italian (in the case of music terms). The term is embedded in the target language without changing or adapting any part of the original source language term. The terms are usually explained in the target language to enable users to use them appropriately.

bona fide (in good faith; te goeder trou)

mutatis mutandis (with the necessary alterations; met die nodige veranderinge)

non compos mentis (not in full possession of his faculties, insane; nie by sy volle verstand nie)

sub iudice (pending; nog hangende)

vice versa (the other way round; omgekeerd)

allegretto (with brisk movement; met lewendige beweging)

allegro (somewhat brisk; ietwat lewendig)

andante (slow; langsaam)

andantino (fairly slow; taamlik langsaam)

\section{Example 5}

\section{(d) extension of meaning}

An existing word is used but its meaning is broadened to encompass the new concept.

bafanabafana ("boys"): term for national soccer team that can be regarded as young competitors ("boys") in the international soccer scene

\section{Example 6}

\section{(e) neologisms (new coinages)}

New terms have to be coined for new inventions, situations, articles, etc.

cellular phone (term equivalents: selfoon, iselula, selula founo, selula founu ...)

unleaded petrol (term equivalents: ongelode petrol ...)

\section{Example 7}




\subsection{Communicative dimension}

The communicative dimension mostly encompasses various issues concerning the standardisation and functional value of terminology.

The terminology usually exists in the various languages, but it needs to be documented. Language development is possible by documenting the terminology in a systematic way. A language can only be developed if the mothertongue speakers of such a language work together to give the language a functional value. The Afrikaans-Japanese Learner's Dictionary (Sakurai and Kotzé: forthcoming) is a good example of the functionality of a language: the Japanese felt the need to communicate with Afrikaans-speaking South African farmers to sell their farming implements. They therefore compiled a bilingual, bidirectional pronunciation dictionary.

One should try to encode the information in such a way that the user can retrieve as much information as possible. By supplying only term equivalents in a developing language, the terminologist not really assists the user to retrieve or use the dictionary information. In the case of developing languages, a terminologist should rather supply definitions in the target languages. The mothertongue speaker will then be able to retrieve information on the concept and will be able to put concept, definition and source language into perspective. The mother-tongue equivalent may for instance exist in the language and when the user can place source term and concept into a logical pattern or classification system, he/she may be able to supply the relevant term equivalent. Term equivalents will derive spontaneously from definitions if they do not yet exist. Mother-tongue speakers will also determine which terms will penetrate, and will discard the artificial or forced creations.

Terms that are coined during the developing phase of a language tend to encompass an explanation of the concepts in the newly coined terms (cf. Example 8). This is an attempt at conveying to the user the meaning attached to the term. As the terminology of a specific subject field becomes part of the language, the user will disregard the long, explanatory terms and rather use the shorter ones and the short version will become the standardised term.

English: wall socket

Afrikaans: muursok (previously kontaksteekdoos, probably from German: Stechdose (English: socket)

\section{Example 8}

The lack of standardisation in African language terminology is frequently regarded as a major obstacle for the development of the African languages. However, standardisation is a process which requires time. The development and standardisation of terminology in for instance Afrikaans was a long pro- 
cess. Various terms were suggested for specific concepts, some terms penetrated in the language, some terms were discarded, while others remained dictionary entries. The terms rekenaar and komper were suggested as term equivalents for the term computer. Although many Afrikaans-speaking people felt that term rekenaar should rather be used for the term calculator and that the shorter, transliterated term komper should be used for computer, the term rekenaar penetrated into the language through usage by both subject specialists and laypeople and komper was discarded.

The database system at the National Language Service provides for the entering of information on various aspects concerning a term. The preferred term can be indicated by a label and its synonyms (or varieties) can be entered. Geographical preference, rural or urban usage, old or modern varieties, vulgar or offensive terms, etc. can also be indicated Once a specific form is preferred to others (and is therefore standardised), this can be indicated in the database and users can be referred to the standardised term.

\section{Consultation}

Terminologists never work in isolation. They consult subject specialists when dealing with the concepts and terms of a specific subject field, and linguists, mother-tongue speakers, and language committees when providing term equivalents or when coining terms.

\subsection{Subject specialists and committee meetings}

Subject specialists form part of a team during the compilation of a specific technical dictionary. They become part of a committee which will discuss the terminology at regular intervals. Subject specialists also provide input by commenting on draft terminology lists in their subject fields.

\subsection{Linguists and language committees}

Terminologists usually start from a specific source language. In South Africa, the source language is usually English and term equivalents have to be given in the other official South African languages. When supplying term equivalents or coining new terms, terminologists consult linguists, language practitioners, language users and mother-tongue speakers.

It is important that linguists (such as language specific committees) and mother-tongue speakers comment on the terms so as to lend authority to the term equivalents. By obtaining consent from subject specialists as well as from linguists and mother-tongue speakers, terms will be used by both experts and laypeople in the user's environment. Only terms that are both technically and 
linguistically sound will penetrate into a language and will disseminate into the subject field through the language.

\section{Cultural Differences}

When dealing with the concepts and terms of the specific subject field, terminologists should have a sound background of the subject field as well as the cultural differences between language groups (or even countries). The terms naming numerals may have different values attached to them in different countries and may be confusing. Examples of this can be found in such subject fields as astronomy, physics, mathematics, economics, etc., where billion $=10^{12}$ according to the British/German system but billion $=10^{9}$ according to the American $/$ French system and trillion $=10^{18}$ according to the British $/$ German system but trillion $=10^{12}$ according to the American/French system (Gove 1976, Sinclair 1995). Afrikaans followed the naming pattern of the British/German system (cf. De Klerk 1990, and see Example 9).

\begin{tabular}{|c|c|c|c|c|c|}
\hline Exponent & $\begin{array}{l}\text { Scientific } \\
\text { Name }\end{array}$ & Symbol & $\begin{array}{l}\text { British/ } \\
\text { German }\end{array}$ & $\begin{array}{l}\text { American/ } \\
\text { French }\end{array}$ & Afrikaans \\
\hline $10^{18}$ & exa-/eksa- & $\mathrm{E}$ & trillion & quintillion & triljoen \\
\hline $10^{15}$ & peta- & $\mathrm{P}$ & billiard & quadrillion & biljard \\
\hline $10^{12}$ & tera- & $\mathrm{T}$ & billion & trillion & biljoen \\
\hline $10^{9}$ & giga- & G & milliard & billion & miljard \\
\hline $10^{6}$ & mega- & $\mathrm{M}$ & million & million & miljoen \\
\hline $10^{3}$ & kilo- & k & thousand & thousand & duisend \\
\hline
\end{tabular}

\section{Example 9}

A technical dictionary or a terminological database should guide the user with language and style usage, with the differences in the interpretation and translation of certain concepts, as well as with misinterpreting, misstatements and misrepresentations (see Examples 10, 11 and 12).

Culture plays an important role in the translation of terms. The translation equivalent must be acceptable to the community (see Example 10):

Bible translators had to translate the term fish with snake in the Khoisan Bible.

In another linguistic environment the term bread had to be replaced with porridge because of a lack of contextual knowledge regarding the target users.

Example 10 
Cultural differences may entail a difference in concept definition, e.g. the term prostitute (see Example 11):

prostitute: In English or another European language context this term

(a) coincides with the exchange of sexual services for money or goods between two or more people, and

(b) may refer to a man or a woman.

prostitute: In Gambian context (an African language) this term [Wolof: chagga; Mandinka: cakoo]

(a) only applies to a woman, but with a different definition to that of a prostitute in Western countries, and

(b) is used if a woman's conduct includes one or more of the following activities:

(i) the exchange of sexual services for money or goods,

(ii) living unmarried,

(iii) wearing trousers,

(iv) smoking in public,

(v) drinking beer,

(vi) walking with a man who is not her kin, husband or husband's friend, or

(vii) walking too much.

\section{Example 11}

Terminologists should also be sensitive to the inclusion of offensive or sensitive terms in the database or terminology list. Terminology is by nature abstract and exact and is therefore to a great extent secure against emotive connotations which may be attached to common words (cf. Example 12):

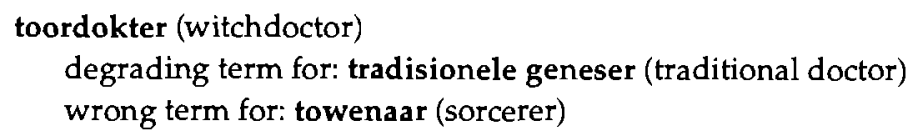

\section{Example 12}

\section{Terminology in South Africa}

There are several factors influencing the terminological development of the South African languages. Most of these factors are of a sociolinguistic nature.

The development of terminology in South Africa has been hampered by a number of ideological, historical, and educational factors, "the most funda- 
mental of which are the language policies adopted in the Republic of South Africa (RSA)" (Mtintsilana and Morris 1988: 109).

With English and Afrikaans being the official languages in the Republic of South Africa up to 1994, the State actively supported terminology development in Afrikaans in an attempt to ensure parity with English.

Since 1985, structural and policy factors have had an effect on the practice of terminology in South Africa. Some language bureaux have either been dissolved or reduced to perform a minimum of functions. It has also been accepted as the responsibility of the State to also develop and promote the African languages.

The government policy in language promotion before 1994 stipulated that the promotion of the African languages was the task of the former national states and the self-governing regions, and not that of the South African Government. The Language Boards for the African languages responsible for terminological work in the former Republic of South Africa did very little work in this regard.

All these factors stress the importance of the Terminology Division of the National Language Service as an institution working on a national basis to modernise and standardise the various technical vocabularies used in South Africa by compiling multilingual technical dictionaries.

The Terminology Division of the NLS is the largest (and at the moment the only) organisation in South Africa which devotes its time entirely to terminology work. Its mission is to assist with the development and modernisation of the technical vocabularies of all national South African languages. Its aim is to support the Government in the formulation, development, implementation and maintenance of national policy and strategies concerning technical languages in order to promote scientific and technical communication in all South African language communities. It also aims to standardise technical and scientific concepts and definitions and to provide equivalents (i.e. development or elaboration of terminology) in all the official languages and in different domains - from grassroots level up to the highest tertiary level.

The Terminology Division of the NLS has the infrastructure to perform this task. It employs language practitioners (terminologists) for all the indigenous languages and with these appointments, the office has attained the human resources and skills to produce the relevant terminology products.

The Terminology Division of the NLS aims to provide a service to the community. Clients of the office include all persons in South Africa who are concerned with education and training, as well as interpreters, translators, copywriters, journalists and all other career groups involved in communication in one way or the other. An important function of the Terminology Division of the NLS is to provide a terminology query service.

The Terminology Division of the NLS documents terminological information and disseminates this information in various ways. The best known way is by means of dictionaries, but the office is also researching possibilities to make this information available in electronic form. 
In the past, bilingual technical dictionaries in English and Afrikaans were primarily compiled, but at present there is a pressing need for multilingual dictionaries with the addition of extra information such as definitions and explanations (especially in the various African languages), in various domains and levels of communication.

The Terminology Division of the NLS is steadily acting in a more supporting capacity through guidance, project facilitation and outside liaison. Various exhibitions are held annually in order to market the activities and facilities of the NLS as well as to draw attention to the availability and advantages of the on-line National Termbank.

The Terminology Division of the NLS plans to disseminate terminological information through the Internet, which gives rise to various questions concerning copyright on terminology and technical dictionary products.

\section{Training}

Apart from in-house training sessions, the Terminology Division of the NLS offers training sessions to individuals and bodies outside the NLS. The purpose of these sessions is to explain the principles underlying terminology work. A part of the training involves the demonstration of computer applications in the processing of terminology and terminography.

Due to a lack of personnel, the Terminology Division of the NLS cannot fulfil in all the expressed terminology needs. Therefore the office aims to extend its training programme in the near future. Various workshops and winter schools (with terminology experts from abroad as trainers) are planned to train collaborators in the principles and practice of terminology work. The training will enable collaborators to work according to fixed terminological procedures and to provide the National Term Bank with terminology related to their various specialist fields and domains. The Terminology Division of the NLS will then be in a position to serve as a clearing house which specialises in the standardisation, presentation and dissemination of terminology in all official languages.

"The grassroots creativity of every speech community should be exploited and channels should be created to enable new terms at this level to be introduced into the central termbank," suggests LANGTAG (1996: 84). "Schools, universities, newspapers, local administrations, etc. should be encouraged to send in their new terms to the National Terminology Services."

At the moment terminology training receives little attention in lexicography or translation modules of South African universities. The training of terminologists and terminographers should receive more attention at tertiary level. Training should be offered either in a department of languages (e.g. English, Afrikaans or African languages) or in a department of linguistics. "It should be an optional topic that students can take as part of their undergraduate studies," proposes LANGTAG (1996: 82). "Training should include basic 
lexicography, terminography and translation studies. Students can then specialise in their Honours studies."

\section{Conclusion}

Irrespective of how well-trained and resourceful the terminologist may be and irrespective of how elegant and sophisticated the set of terms is that he or she creates, large scale term creation will remain a wasteful endeavour unless the end product is appreciated and fully utilised by all those involved in the relevant subject domain - i.e. in research, teaching, translating, etc. "Important," stresses Louwrens (1996: 7), "is that this appreciation must emanate from the people themselves, since one can never succeed by forcing a language onto its speakers."

The development of the languages is to a certain extent the task of the Government, but every citizen should make it his/her task to develop the terminology of his/her mother-tongue - at least in his/her own workplace. By these means all languages will be developed and be given a functional value.

\section{References}

Alberts, M. 1990. ' $n$ Bepaling van Afrikaanse vakleksikografiese behoeftes. D.Litt. et Phil. thesis. Pretoria: University of South Africa.

Baca, M. 1997. International Terminology Working Group Minutes. Paris, Offices of the Inventaire Général, September 5, 1997.

Carstens, A. 1997. Introduction to Terminology and Terminography. Pretoria: University of Pretoria.

Cluver, A.D. de V. 1989. A Manual of Terminography. Pretoria: HSRC.

De Klerk, J.H. 1990. Sterrekundewoordeboek/Dictionany of Astronomy. Potchefstroom: Potchefstroom Herald.

Gove, P.B. (Ed.). 1976. Webster's Third New International Dictionary of the English Language. Springfield, Mass.: Merriam Webster.

Joseph, J. 1984. The Elaboration of an Emerging Standard. Language Sciences 6(1): 39-52.

LANGTAG. 1996. Towards a National Language Plan for South Africa: Final Report of the Language Plan Task Group (LANGTAG). Pretoria: Department of Arts, Culture, Science and Technology.

Louwrens, L.J. 1996. On the Development of Scientific Terminology in African Languages: The Terminographer's Dilemma in a New Dispensation. Lexikos 7: 245-251.

Mtintsilana, Priscilla N. and Rose Morris. 1988. Terminography in African Languages in South Africa. South African Journal of African Languages 8(4): 109-113.

Sager, J.C. 1990. A Practical Course in Terminology Processing. Amsterdam: John Benjamins.

Sakurai, T. and E.F. Kotzé. Forthcoming. Afrikaans-Japannese Aanleerderswoordeboek met Engelse vertalings. (Afrikaans-Japanese Leamer's Dictionary with English translations). Tokyo: Daigaku Shorin.

Sinclair, John (Ed.). 1995. Collins COBUILD English Dictionary. London: HarperCollins.

Sonneveld, H. 1997. Terminological Principles and Methods in the Translation of Thesauri. Baca, M. International Terminology Working Group Minutes. Paris, Offices of the Inventaire Gerneral, September 5, 1997. 


\title{
Die mikrostrukturele bewerking van affikse in Afrikaanse vertalende woordeboeke*
}

\author{
Gerda de Wet, Departement Afrikaans en Nederlands, Universiteit van Stel- \\ lenbosch, Stellenbosch, Republiek van Suid-Afrika
}

\begin{abstract}
The Microstructural Treatment of Affixes in Afrikaans Translation Dictionaries. The microstructural treatment of affix lemmata in Afrikaans translation dictionaries is currently inadequate. In the dictionaries under discussion, namely Tweetalige Woordeboek / Bilingual Dictionary (BD) and Groot Woordeboek / Major Dictionary (MD) which are presently viewed as the leading translation desk-top dictionaries, affixes are included rarely. And if they are included as affix lemmata, their treatment is cursory. BD and MD are not very user-friendly and force the user to rely largely on his/her intuition for the meaning and use of affix lemmata. Consequently these dictionaries do not consistently fulfil their role as sources of information. This article considers a number of information categories according to which the lexicographer should treat affix lemmata in the dictionary so that they may be of value to the user. These categories include semantic information such as polysemy, homonymy and synonymy, etymological information, as well as pronunciation and grammatical information.
\end{abstract}

Keywords: AFRIKAANS TRANSLATION DICTIONARIES, AFFIXES, AFFIX LEMMATA, INFORMATION CATEGORIES, POLYSEMY, HOMONYMY, SYNONYMY, ETYMOLOGICAL INFORMATION, PRONUNCIATION, GRAMMATICAL INFORMATION

Opsomming: Die mikrostrukturele bewerking van affigale lemmas in Afrikaanse vertalende woordeboeke is tans nog onvoldoende. In die woordeboeke onder bespreking, naamlik Tweetalige Woordeboek / Bilingual Dictionary (TW) en Groot Woordeboek / Major Dictionary (GW) wat tans as die toonaangewende vertalende handwoordeboeke beskou word, word affikse selde opgeneem. En waar hulle wel as affigale lemmas opgeneem word, is die bewerking oppervlakkig. GW en TW is nie baie gebruikersvriendelik nie en dwing die gebruiker om in 'n groot mate op sy/haar intuïsie staat te maak vir die betekenis en gebruik van affigale lemmas. Gevolglik vervul hierdie woordeboeke nie hulle rol as inligtingsbronne konsekwent nie. Hierdie artikel beskou 'n aantal inligtingstipes waarvolgens die leksikograaf affigale lemmas in die woordeboek behoort te bewerk, sodat hulle vir die gebruiker van waarde is. Hierdie kategorieë sluit semantiese inligting soos polisemie, homonimie en sinonimie, etimologiese inligting, asook uitspraak- en grammatikale inligting in.

* Hierdie artikel is 'n aangepaste hoofstuk uit 'n M.A.-skripsie Die opname en bewerking van subleksikale lemmas in Afrikanse vertalende woordeboeke wat in Desember 1997 deur die Universiteit van Stellenbosch aanvaar is. 
Sleutelwoorde: AFRIKAANSE VERTALENDE WOORDEBOEKE, AFFIKSE, AFFIGALE LEMMAS, INLIGTINGSTIPES, POLISEMIE, HOMONIMIE, SINONIMIE, ETIMOLOGIE, UITSPRAAKINLIGTING, GRAMMATIKALE INLIGTING

\section{Inleiding}

Die opname van affikse in die makrostruktuur van vertalende handwoordeboeke is reeds in 'n vorige artikel (De Wet 1998: 154-172) bespreek. Daarin is genoem dat Afrikaanse woordeboeke veral op die opname van woorde as lemmas in die makrostruktuur gekonsentreer het en dat subleksikale en multileksikale lemmas nie voldoende aandag geniet het nie. In hierdie artikel word die mikrostrukturele bewerking van affigale lemmas bespreek en word voorstelle gemaak aan die hand waarvan die bestaande stelsel in vertalende woordeboeke met Afrikaans en Engels as taalpaar, uitgebrei en verbeter kan word. Daar is vrylik by die verklarende leksikografie geleen in gevalle waar dit die bestaande stelsel in vertalende woordeboeke kan uitbrei of verbeter. Die twee woordeboeke onder bespreking is Tweetalige Woordeboek/Bilingual Dictionary (TW) en Groot Woordeboek/Major Dictionary (GW).

Die volgende lemmatiese inskrywings in hierdie woordeboeke demonstreer die onvolledigheid wat in hierdie artikel ter sprake kom:

$$
\text { her }=\text {, re }=
$$

aan die A-E kant van GW, en

$$
\text { non- nie- }
$$

aan die E-A kant van TW.

Die bewerking van die prefiks her- is heeltemal onbevredigend vir die woordeboekgebruiker, omdat laasgenoemde sy eie gevolgtrekkings moet maak oor die optrede van die prefiks in gelede woorde. Dit is byvoorbeeld nie duidelik of her- en re- mekaar in alle vertalende kontekste kan vervang nie. Kan her- soos in herbewerk en re- soos in rework mekaar altyd vertaal, of is daar uitsonderings waar her- en re- mekaar nie kan vertaal nie al het hulle dieselfde betekenis? Dieselfde geld vir non- en nie-. Hierdie oppervlakkige bewerking van affigale lemmas laat die gebruiker met baie onduidelikhede en as inligtingsbron vervul die woordeboek nie sy rol konsekwent nie. Vervolgens sal die verskillende inligtingstipes aan die hand waarvan die leksikograaf affigale lemmas in vertalende woordeboeke behoort te behandel, van nader beskou word. Hieronder ressorteer semantiese inligting, etimologiese inligting, uitspraak- en grammatikale inligting. Onder semantiese inligting word ook na omkeerbaarheid tussen 'n lemma en sy vertaalekwivalente gekyk. 


\section{Semantiese inligting}

'n Algemene woordeboek dien grootliks as bron van betekenisinligting vir die gewone woordeboekgebruiker. Ander aspekte, soos grammatikale inligting, uitspraakleiding, ensovoorts is gewoonlik ondergeskik aan semantiese inligting. Semantiese probleme ter sake vir die vertalende woordeboek is verskillend en meer ingewikkeld as dié vir 'n eentalige verklarende woordeboek (AlKasimi 1977: 58). Die eentalige woordeboek is meestal op 'n spesifieke kultuur afgestem, dit wil sê die taal waarop die woordeboek gerig is, is normaalweg die taal en kultuur van die gebruiker. In die geval van 'n vertalende woordeboek verskil die gebruiker se taal gewoonlik van een van die tale van die woordeboek en die gepaardgaande kultuur waarop dit gerig is. En juis dít maak dit vir die leksikograaf byna ' $n$ taak van onmoontlikheid om in alle kontekste voldoende semantiese leiding te gee.

Daar is verskillende aspekte wat onder semantiese inligting aangebied kan word, waarvan ek hier net drie betekenisonderskeidinge sal behandel, naamlik polisemie, homonimie en sinonimie. Daar word eerstens gekyk hoe woordlemmas bewerk word en aan die hand daarvan word die bewerking van subleksikale lemmas bestudeer.

\subsection{Polisemie en homonimie}

Polisemie is die verskynsel dat ' $n$ leksikale item verskillende betekenisonderskeidings het wat sinchronies met mekaar verband hou. GW maak voorsiening vir die volgende doeltaalvorme wat as vertaalekwivalente van die verskillende polisemiese waardes van index (E-A) kan optree:

index [...] bladwyser; inhoudsopgawe; naamlys; register, klapper; indeks (ekon.); teken; tongetjie (skaal); eksponent (wisk.); aanwysing, aanduiding; indeks, verbodlys; wysvinger; wyser [...].

'n Soortgelyke geval kom in TW voor waar die volgende doeltaalvorme as vertaalekwivalente van die verskillende polisemiese waardes van corner (E-A) gegee word:

corner [...] hoek, hoekie; opkoopspekulasie; monopolie; hoekhou, hoekslag (hokkie); hoekskop (sokker) [...].

In vertalende woordeboeke soos GW en TW word die polisemie van die lemma aangedui deurdat die vertaalekwivalente wat die verskillende polisemiese waardes van die lemma verteenwoordig, met kommapunte van mekaar geskei word - hier gaan dit om 'n divergente ekwivalentverhouding tussen die lemma en sy vertaalekwivalente. Uit die voorbeelde blyk dit dus dat die reekse vertaalekwivalente by sowel index as corner die verskillende polisemiese 
optredes van die twee woorde in die doeltaal verteenwoordig. Dit impliseer dat die vertaalekwivalente elkeen binne ' $n$ gegewe konteks as doeltaalvervanger van die lemma kan optree.

Hierdie stelsel is onbevredigend, aangesien daar geen aanduiding is binne watter konteks die verskillende vertaalekwivalente gebruik kan word nie. Uit die tipografie van die woordeboek moet die gebruiker aflei dat die lemma in een of ander konteks met al die doeltaalvorme vervang kan word en slegs die sporadiese aanwending van etikette is 'n leidraad dat die betrokke vertaalekwivalent in ' $n$ spesifieke konteks gebruik moet word. Dit beteken dat die gebruiker ingelig moet wees oor die funksie van kommas en kommapunte in die vertalende woordeboek - deur toeligting in die voorwerk — anders kan hy/sy uit so ' $n$ vertaalekwivalentparadigma verstaan dat index of corner binne ' $n$ gegewe konteks met enige van die vertaalekwivalente vervang kan word. Die konvensies waarvolgens woordeboeke sekere inligting aanbied - soos die skeiding van sinonimiese vertaalekwivalente deur kommas - moet aan die gebruiker verskaf word, sodat die woordeboek meer toeganklik is en 'n optimale inligtingsoordrag verseker - en hierdie leiding ontbreek in beide TW en GW.

Hierdie stelsel impliseer verder dat die gegewe vertaalekwivalente nie die lemma in alle kontekste kan vervang nie, maar dui nie die verband aan waarbinne hulle die lemma wél kan vervang nie. Hierdie gebrekkige inligtingsoordrag is egter nie net te wyte aan die gebruik van kommapunte nie, want etikette, kontekstuele gegewens en effektiewe voorbeeldmateriaal kan ook aangewend word om ' $n$ meer vereenduidigende lesing te verkry.

' $n$ Verdere probleem is dat nie al die vertaalekwivalente polisemiese verbande skyn te vertoon nie. By sowel index as corner kom groepe vertaalekwivalente voor wat nie sonder meer as polisemiese inskrywings hanteer kan word nie. In hierdie gevalle moet die lemmas as homonieme behandel word.

\subsubsection{Tipografiese onderskeid tussen die aanbieding van polisemiese en homonimiese lemmas}

Verklarende woordeboeke soos HAT gebruik verskillende numeriese stelsels om homonimiese en polisemiese betekeniswaardes te merk. Soos in vertalende woordeboeke, word homonimiese lemmas in verklarende woordeboeke met behulp van ' $n$ boskrif aangedui, byvoorbeeld in HAT: $-\mathbf{i e}^{1},-\mathbf{i e}^{2}$ en $-\mathrm{ie}^{3}$. Polisemie word aangedui deur 'n numeriese merker as mikrostrukuuraanduider te gebruik om 'n betekenisonderskeiding te merk, byvoorbeeld in WAT:

$$
-\operatorname{lik}[\ldots] 1 \text { a }[\ldots] \text { b }[\ldots] 2 \text { a }[\ldots] \text { b }[\ldots] 3[\ldots] .
$$

Dit kom egter selde voor dat affigale lemmas in Afrikaanse vertalende woordeboeke as homonieme opgeneem word. Affikse wat vormlik ooreenstem, maar onverwante betekenisse het, word nie as verskillende lemmas opgeneem nie, maar gewoonlik in een artikel behandel, en ook nie polisemies nie, maar as ' $n$ 
monosemiese affiks. In hierdie opsig is die Afrikaanse verklarende leksikografie ook die vertalende leksikografie vooruit. So 'n geval is die twee suffikse -iel. Ten spyte van die feit dat hulle nie in GW of TW as affigale lemmas opgeneem is nie, behoort hulle verder ook as ' $n$ homonimiese paar opgeneem te word. HAT maak voorsiening vir twee homonimiese inskrywings onder -iel, naamlik:

-iel ${ }^{1}$ Agtervoegsel afgelei van G. hule (stof), en gebruik by die vorming van die name van sekere chemikalieë, veral nitriele en radikale, waar dit "(chemiese) radikaal" beteken, bv. in asetonitriel, hidroksiel, bensoïl.

-iel ${ }^{2}$ Agtervoegsel afgelei van F. -ile < L. -ilis en gebruik in die vorming van (a) 'n aantal substantiewe waarin dit die betekenis het van "stof verwant aan wat deur die grondwoord aangedui word", bv. bensiel; (b) 'n aantal adjektiewe waarin dit "van, betreffende, geskik vir, in staat tot; -baar, -agtig" beteken, bv. in futiel, infantiel, pueriel.

Vertalende woordeboeke behoort aan affigale lemmas hul regmatige plek te gee. Hoewel HAT nog nie affigale lemmas konsekwent, waar van toepassing, as polisemiese items of homonieme opneem nie, het HAT verder op dié terrein gevorder as GW en TW.

Die gebruik in vertalende woordeboeke is normaalweg om vertaalekwivalente wat verskillende waardes van 'n polisemiese lemma verteenwoordig, met kommapunte te skei. 'n Stelsel van nommering behoort ook in Afrikaanse vertalende woordeboeke ingevoer te word aan die hand waarvan die vertaalekwivalente van 'n polisemiese lemma gemerk word. Die argument teen hierdie metode is onder andere dat te veel ruimte daardeur in beslag geneem word. Ter wille van effektiewe inligtingsoordrag is die opoffering van dié ruimte egter die moeite werd. Deur ' $n$ toepaslike nommering te gebruik wat ' $n$ duidelike tipografiese onderskeid bewerkstellig, kan vir die woordeboekgebruiker net 'n duideliker semantiese onderskeid tot gevolg hê. So 'n stelsel van nommering sal net so 'n aanwins in die geval van leksikale en multileksikale lemmas wees. Dit behoort nie net tot die artikels van subleksikale lemmas beperk te word nie.

Tweetalige Aanleerderswoordeboek is een van die eerste Afrikaanse vertalende woordeboeke waarin ' $n$ polisemiese lemma se vertaalekwivalente deur middel van 'n nommeringstelsel onderskei word. Uit die artikel van die twee homonimiese lemmas cry ${ }^{1}$ en cry $^{2}$ (E-A) is dit duidelik dat nommering 'n baie meer vereenduidigende lesing bewerkstellig sodat duidelik tussen die verskillende betekeniswaardes onderskei kan word:

cry $^{1} 1$ geroep [...] 2 skree, skreeu, kreet, gil [...]

cry $^{2} 1$ huil [...] 2 skree, skreeu, roep [...] 
Langenscheidts Großes Schulwörterbuch (LGS) (1988) is 'n vertalende woordeboek, Duits-Engels (D-E)/Engels-Duits (E-D), gerig op die Duitse moedertaalspreker. In hierdie woordeboek word polisemie by beide leksikale en subleksikale lemmas numeries aangedui. Dit lei tot 'n baie doeltreffende inligtingsoordrag. Vergelyk die affigale lemma re- (E-D):

re- in Zssgn 1. [ri:] wieder, noch einmal, neu: reprint, rebirth; 2. [ri] zurück, wider: revert, retract.

'n Genommerde aanbieding van die vertaalekwivalente maak dit vir die gebruiker makliker om tussen die verskillende betekeniswaardes van die doeltaalvorme te onderskei. Deur die nommering van 'n doeltaalinskrywing word daar onmiddellik 'n opvallende semantiese en tipografiese hiërargie geskep waarvolgens die doeltaalinskrywings gerangskik word. Die nommering op sigself dra nie by tot ' $n$ duidelike onderskeid van die betekeniswaardes nie - dit word verkry deur verdere leksikografiese bewerking, maar hierdie metode ekspliseer wel die lemma se polisemiese karakter en wys daarop dat verskillende vertaalekwivalente vir verskillende polisemiese optredes van die lemma gebruik moet word.

'n Ordening volgens gebruiksfrekwensie soos dié van LGS is 'n maklike manier om die polisemiese paradigma van die brontaalvorm te weerspieël. Anders as wat die geval is met kommapunte, skep die nommeringstelsel 'n opvallende tipografiese hiërargie wat makliker raakgesien word.

Die stelsel waarvolgens polisemie en homonimie in die woordeboek hanteer word, behoort noukeurig in die toeligtende aantekeninge van die woordeboek beskryf te word. Dit beteken die leksikograaf moet argumentshalwe aandui dat die inskrywings onder 1. 'n vertaalekwivalent van die lemma se gebruiklikste polisemiese waarde is of dat daar ' $n$ verskil in uitspraak is tussen 1. en 2., of wat die geval ook al mag wees. Die gebruiker moet ingelig wees waarom 1. eerste staan en nie laaste in die artikel nie en dit moet in terme van die lemma se waardes verduidelik word.

\subsubsection{Die lemmatisering van leksikale items wat elders in die woordeboek as vertaalekwivalente verskyn}

In die vertalende leksikografie heers die veronderstelling dat elke leksikonitem wat as vertaalekwivalent aan die $X-Y$ kant van die woordeboek opgeneem word, op sy beurt as lemma aan die $Y$-X kant gegee moet word. Dit wil sê dat in ' $n$ artikel soos die volgende in TW, die vertaalekwivalente van die lemma eg aan die A-E kant, almal weer op hul beurt aan die E-A kant as lemmas opgeneem moet word met $\mathrm{eg}$ as een van die Afrikaanse vertaalekwivalente:

eg $[\ldots]$ true $[. .$.$] genuine; authentic; solid [\ldots]$; trueborn $[\ldots]$ 
Die vertaalekwivalente van eg wat aan die E-A kant as lemmas opgeneem is, is die volgende:

true [...] waar; juis; eg [...]

genuine waar, werklik, opreg, eg, onvervals [...]

authentic (lewens)eg, waar, outentiek, oorspronklik; betroubaar, geloofwaardig; geldig.

solid [...] vas; solied, sterk, stewig, massief; onverdeeld, eenparig; gegrond, deeglik, eg; vasstaande; kubiek.

true-born reggeaard, opreg, eg; raseg, =suiwer.

Uit hierdie voorbeeld en vele ander, lyk dit of TW wel konsekwent vertaalekwivalente van leksikale lemmas as lemmas opneem en sodoende die omkeerbaarheidsbeginsel handhaaf. Wat die subleksikale lemmas betref, word dit nie so konsekwent deurgevoer nie. In die geval van eks= met sy enigste vertaalekwivalent ex- is die omkeerbaarheidsbeginsel wel toegepas: aan die E-A kant word die subleksikale lemma ex- opgeneem, met die vertaalekwivalente oud-, eks-; gewese, voormalige.

Daar is egter gevalle waar TW nie aan die omkeerbaarheidsbeginsel voldoen nie. Die volgende inskrywing is 'n goeie voorbeeld (A-E):

her= prefix again, re=; used so freely esp. with verbs that a full list cannot be given.

Die omgekeerde vind egter nie plaas nie. Die affiks re= word nie as subleksikale lemma aan die E-A kant opgeneem nie. Die ideaal sou wees dat re= wél as affigale lemma aan die E-A kant gegee word met onder andere sy drie moontlike subleksikale vertaalekwivalente her-, re- en terug-. Hier ter sake is die feit dat die woordeboek op 'n spesifieke teikengebruiker afgestem is. In die geval van TW is dit meer op die Afrikaanse moedertaalspreker gerig as op die Engelse moedertaalspreker, en dit is daarom te verwagte dat die E-A kant vollediger bewerk sou wees as die A-E kant, want die implikasie is dat die Afrikaanssprekende gebruiker se Engels nie so goed soos sy Afrikaans is nie. In hierdie geval word daar nie aan die verwagting voldoen nie, maar by gevalle soos post $=$ en non $=$ wel.

Die affiks post= is as subleksikale lemma aan die E-A kant opgeneem met slegs sy een vertaalekwivalent na=. Die affiks na= word nie as lemma aan die A-E kant van die woordeboek gegee nie. Wat gebeur, is dat na= as soekelement opgeneem word met 'n hele reeks inskrywings daaronder. Die artikels waarin na= bewerk is, het as inskrywings $n a=:$-aap, $n a=:$ doen, $n a=: \sim$ genoeg, $n a=$ : $\sim$ laat, $n a=: \sim$ rede en $n a=: \sim$ tafel. Dat die omkeerbaarheidsbeginsel nie gehandhaaf is nie, blyk baie duidelik uit hierdie voorbeeld. Die probleem lê by TW se stelsel van die aangee van soekelemente. Dit blyk dat die opstellers van die woordeboek self onduidelikheid het oor die onderskeid tussen lemmas en deel- 
lemmas met 'n lemma-eksterne ingangsposisie en daarom nie na= ook as subleksikale lemma opgeneem het nie. Die affiks na- behoort naas sy optrede as deellemma, ook as subleksikale lemma gegee te word.

Alhoewel post= ' $n$ lid van die Afrikaanse leksikon is, soos blyk uit gelede woorde soos postmodernisme en postnataal, word dit nie as 'n moontlike vertaalekwivalent van post $=(\mathrm{E}-\mathrm{A})$ opgeneem nie. Om na $=$ as enigste vertaalekwivalentparadigma van post $=$ te gee, skep die indruk dat na $=(A-E)$ post $=(E-A)$ in alle kontekste kan vervang. Dit is egter nie die geval nie, aangesien namodernisme en nanataal nie gebruik word nie, maar slegs postmodernisme en postnataal. Die affiks post $=$ word verder ook nie as subleksikale lemma aan die A-E kant opgeneem nie. Die leksikograwe het post=skynbaar nie as deel van die Afrikaanse leksikon gereken nie en daarom nie in die makrostruktuur van die woordeboek opgeneem nie. Dit het moontlik daartoe gelei dat post $=$ nie as vertaalekwivalent van post $=(E-A)$ opgeneem is nie.

'n Soortgelyke geval is die Engelse non- wat slegs met nie- vertaal is sonder om ook vir non- as Afrikaanse vertaalekwivalent voorsiening te maak. Die prefiks nie- word nie as subleksikale lemma aan die A-E kant van die woordeboek opgeneem nie. Dit lyk of dieselfde probleem hier voorkom as wat die geval is met post=. Op sy beurt word nie- slegs as soekelement aan die A-E kant opgeneem, wat begin met nie: - metaal. Ook in hierdie geval word die omkeerbaarheidsbeginsel nie toegepas nie. Anders as in die geval van post= wat nóg as Afrikaanse vertaalekwivalent van post $=(\mathrm{E}-\mathrm{A})$ nóg as affigale lemma (A-E) opgeneem is, word non- (wat nie as vertaalekwivalent van die Engelse non- gegee is nie) as soekelement aan die A-E kant vermeld: non=: -akseptasie. Die opname van non- as soekelement impliseer vir die woordeboekgebruiker dat die opstellers van die woordeboek non- weliswaar as lid van die Afrikaanse leksikon ag. Dit is derhalwe onverklaarbaar waarom non- beide as affigale lemma en as vertaalekwivalent weggelaat is.

Sowel nie- as non- behoort dus as affigale lemmas opgeneem te word, met as vertaalekwivalent onder meer non-. Soos reeds genoem, kan die Engelse non- in sekere gevalle met beide nie- en non- vertaal word. Die vertaalekwivalente moet voorsien word van die een of ander vorm van konteksleiding wanneer non- met nie- en wanneer dit met non- vertaal kan word sodat duidelik onderskei kan word. Dit impliseer dat 'n aanduiding van moontlike styl- en registerverskille ook verstrek moet word aangesien non- en nie-, al het hulle dieselfde betekenis, mekaar nie in alle gevalle kan vervang nie.

Daar is 'n stylverskil tussen prefikse van Romaanse herkoms soos post-en non- en hul Germaanse eweknieë na- en nie-. Hul weglating uit die woordeboek getuig nie slegs van 'n onvolledige bewerking nie, maar moontlik ook van oordrewe purisme aan die kant van die leksikograaf wat die Germaanse vorme wil promoveer. Alhoewel na- en nie- nie as subleksikale lemmas nie, maar wel as neslemmas opgeneem word, kry hulle dus erkenning as lede van die leksikon. 


\subsection{Sinonimie}

Sinonimie verwys na die verskynsel dat twee leksikale items verskillende vorme, maar dieselfde betekenis het. Twee leksikale items het egter selde presies dieselfde betekenis. Hulle kan selde in alle kontekste met mekaar vervang word. Daarom word 'n onderskeid getref tussen absolute sinonieme en gedeeltelike sinonieme. Hierdie verskil word voorts aan die hand van woordlemmas verduidelik.

\subsubsection{Absolute sinonimie}

Absolute sinonieme kan mekaar in alle kontekste vervang sonder dat daar 'n betekenisverskil intree, byvoorbeeld onderwyser en leerkrag. Louw en Nida (1989: xvi) wys egter daarop dat daar byna nooit absolute sinonimie aangetref word nie en sou 'n leksikale item se betekenis direk met 'n ander ooreenstem, kom daar desondanks dikwels styl- en registerverskille voor (sien ook Geeraerts (1986), Leech (1981) en Lyons (1981)). Daar is 'n stylverskil tussen onderwyser en leerkrag wat meebring dat hulle nie sonder meer in alle kontekste met mekaar vervang kan word nie. Tussen hierdie twee leksikale items is daar 'n registerverskil, waarin leerkrag die meer formele woord is. Hieruit blyk dit dat absolute sinonimie nie altyd net op semantiese gronde berus nie, maar dat styl- en registerverskille ook daartoe bydra dat een leksikale item nie noodwendig sy sinonimiese eweknie se plek kan vul nie.

\subsubsection{Gedeeltelike sinonimie}

Gedeeltelike sinonimie is die betekenisbetrekking wat daar tussen leksikale items bestaan op grond van 'n gedeeltelike betekenisoorvleueling. In vertalende woordeboeke word die sinonimiese verhouding tussen vertaalekwivalente deur middel van 'n komma aangedui - soos in die volgende inskrywing in TW:

excuse verontskuldiging, verskoning $[\ldots]$

Die implikasie van die komma tussen die vertaalekwivalente is dat hulle sinonieme van mekaar is, maar ook vertaalekwivalente van die lemma. TW toon hier ' $n$ leemte in dié opsig dat daar nie 'n aanduiding gegee word in watter kontekste die vertaalekwivalente mekaar kan vervang nie. So kan die gebruiker dink dat verontskuldiging en verskoning mekaar in alle kontekste kan vervang, terwyl daar tussen hierdie twee leksikale items inderdaad binne ' $n$ spesifieke konteks ' $n$ betekenisverskil kan voorkom, sodat verontskuldiging nie sonder meer met verskoning vervangbaar is nie. Vergelyk: 
Sy verontskuldiging dra nie vir my veel gewig nie.

Sy verskoning dra nie vir my veel gewig nie.

Die voorsitter het sy verskoning by die sekretaresse ingedien.

*Die voorsitter het sy verontskuldiging by die sekretaresse ingedien.

Louw en Gouws (1996: 92-93) bepleit 'n uitgebreide stelsel van adressering waar nie net die lemma nie, maar ook die vertaalekwivalent(e) die adres is sodat daar nie onduidelikheid bestaan oor die gebruik van die vertaalekwivalent in 'n spesifieke konteks nie. Dit impliseer dat 'n vertalende woordeboek hom nie net kan beperk tot 'n blote lysting van vertaalekwivalente vir 'n spesifieke lemma nie, maar dat die vertaalekwivalente van ekstra inligting voorsien moet word, sodat die betekenis van so ' $n$ vertaalekwivalent in 'n gegewe konteks duidelik blyk. Hierdie inligting heet vertaalkomplemente en het die vertaalekwivalent as adres. TW maak soms gebruik van vertaalkomplemente, byvoorbeeld:

onverbloem(d) undisguised, unconcealed, unvarnished (truth),

waar die implikasie van die konteksleiding truth is dat unvarnished net as sinoniem van onverbloem(d) gebruik kan word as dit na waarheid verwys - soos gestel teenoor leuens.

'n Onderskeid is nodig - soos soms reeds in Afrikaanse verklarende woordeboeke aangetref word - waardeur gedeeltelike sinonimie tussen vertaalekwivalente aangedui kan word, aangesien die komma as merker nie voldoende is nie. Net soos woordlemmas, kan affigale lemmas ook sinonimiese vertaalekwivalente hê. Tans word affigale lemmas in Afrikaanse vertalende woordeboeke meestal net van een vertaalekwivalent voorsien - ongeag of die lemma oor 'n polisemiese uitbreiding beskik of nie.

Vervolgens word die opname van sinonimiese vertaalekwivalente van affigale lemmas van nader beskou.

\section{Doeltaalsinonieme in die artikels van affigale lemmas}

Die Engelse prefiks re- (E-A) kan in Afrikaans vertaal word met her- en re-, asook met terug-. Beide her- en re- het die betekenis "weer", maar nie alle stamme wat met her- verbind, verbind met re- nie, en ook andersom, nie alle stamme wat met re- verbind, verbind met her- nie. Voorbeelde waar her- en remekaar wel ondubbelsinnig kan vervang, is onder andere in herorganiseer en reorganiseer en ook herkonstruksie en rekonstruksie. Gevalle waarin re- hernie sonder meer kan vervang nie, is: 


$\begin{array}{ll}\text { herleef } & \text { *releef } \\ \text { heroorweeg } & { }^{*} \text { reoorweeg } \\ \text { hersien } & \text { *resien } \\ \text { hereksamen } & \text { *reëksamen }\end{array}$

Voorbeelde van afleidings waar her- re- nie sonder meer kan vervang nie, is weer:

$\begin{array}{ll}\text { repatrieer } & { }^{*} \text { herpatrieer } \\ \text { revisie } & { }^{*} \text { hervisie } \\ \text { reinkarnasie } & \text { *herinkarnasie }\end{array}$

Die proses wat hier aan die werk is, veroorsaak dat Romaanse affikse soos rehoofsaaklik verbind met stamme van Romaanse herkoms, terwyl die Germaanse affikse soos her- meestal met beide Romaanse en Germaanse stamme kan verbind. Dit kan ook anders gestel word, naamlik dat Germaanse stamme gewoonlik met Germaanse prefikse verbind, terwyl Romaanse stamme met Romaanse, asook soms met Germaanse prefikse verbind. Tog verbind nie alle Romaanse stamme noodwendig met Germaanse affikse nie. Dit blyk uit voorbeelde soos *herpatrieer, "hervisie en "herinkarnasie waar re- die geskikte prefiks is. Wat hul betekenis betref, is her- en re- dus wel absolute sinonieme, maar vanweë hul etimologie kan hulle mekaar nie onvoorwaardelik in alle kontekste vervang nie. In sulke gevalle moet die leksikograaf duidelike leiding aan die gebruiker gee oor die woordvormingsproses van die betrokke affiks - onder andere deur voorbeeldmateriaal te verskaf en deur in ' $n$ kort aantekening te wys op die beperkinge wat die etimologie van 'n affiks op sy woordvorming met stamme kan plaas. Die leksikograaf behoort ook 'n stelsel in te voer wat 'n tipografiese of ander onderskeid tref tussen vertaalekwivalente wat gedeeltelike sinonieme van mekaar is en dié wat absolute sinonieme is.

Die inskrywings onder re- (E-A) behoort soos volg daar uit te sien:

$$
\text { re- }[\ldots] 1 \mathbf{a} \text { her- }[\ldots] \text { b re- }[\ldots] 2 \text { terug- }[\ldots] \text {. }
$$

Deur gebruik te maak van die letters $\mathbf{a}$ en $\mathbf{b}$ word die gedeeltelike sinonimiese verhouding tussen her- en re- aangedui. Om die woordeboekgebruiker in staat te stel om enkoderend met die woordeboek om te gaan, behoort die beperkings wat daar op die vertaalekwivalente rus, aangedui te word - onder andere deur te wys op die verbinding al dan nie met Romaanse en Germaanse stamme, asook deur voldoende voorbeeldmateriaal te verskaf. Ter wille van duidelikheid kan die leksikograaf ook gevalle verskaf wat nie moontlik is nie, byvoorbeeld, soos vroeër genoem, "releef in die geval van her- of *hervisie in die geval van re-. Die aangawe van foutiewe vorme kan 'n bykomende pedagogiese waarde hê in dié sin dat dit vir die gebruiker duidelik blyk watter vorme nié moontlik is nie. 
Nog so 'n geval is die prefikse dis- en on-. Gouws (1989: 96) wys daarop dat dis- en on- binne 'n bepaalde konteks albei "nie" kan beteken. Die woorde ontydig en dislojaal beteken onderskeidelik "nie tydig" en "nie lojaal". Alhoewel onlojaal wel moontlik is, kan 'n afleiding soos *distydig egter nie gevorm word nie. Die prefiks dis- is 'n Romaanse prefiks en dit verbind gewoonlik net met stamme van Romaanse of klassieke herkoms. Die leksikograaf moet bedag wees op sulke gevalle en die nodige leiding aan die woordeboekgebruiker gee. Al beteken beide prefikse dieselfde, is hulle nie sonder meer onderling vervangbaar nie en die stamme bepaal die beperking wat op die affikse geplaas word.

\section{Etimologiese inligting}

Etimologiese inligting, al is dit in ' $n$ beperkte mate, word al 'n geruime tyd in sommige Afrikaanse verklarende woordeboeke aangedui, maar ontbreek nog grootliks in die vertalende woordeboeke. 'n Moontlike verklaring hiervoor is dat die eentalige woordeboeke gerig is op betekenisverklaring en dat etimologiese inligting groter verband hiermee hou as met vertaalekwivalente, waarop vertalende woordeboeke hoofsaaklik gerig is. Die geldigheid van so 'n verklaring is nie sonder meer bo verdenking nie, alhoewel Svensén (1993: 191) daarop wys dat etimologiese inligting ' $n$ rariteit in vertalende woordeboeke is en, volgens hom, wenslik so:

A bilingual dictionary is aimed at translation; historical information about the source language occurs only exceptionally, and even then seldom for any good reason.

Drysdale (1989: 527) voer die argument verder en sê die "functional value of etymologies in most day-to-day use of the dictionary is very small - except, of course, for students and linguistic scholars".

Die opname van etimologiese inligting in vertalende woordeboeke is nie noodwendig negatief of onaanvaarbaar nie, maar dit behoort sinvol aangewend te word. Etimologiese inligting kan maklik ontaard in onnodige geskiedkundige uitweidings, terwyl 'n sinchroniese woordeboek veronderstel is om die betekenis en gebruik van hedendaagse leksikale items weer te gee. In die mikrostrukturele bewerking van affikse in vertalende woordeboeke is daar nog nie regtig gekyk na die herkoms van affikse nie. Tegnostamme wat as subleksikale lemmas opgeneem word, geniet wel sporadiese aandag wat etimologie betref, juis omdat hul etimologie dikwels ook hul betekenis verklaar.

Die leksikograaf hoef nie, in teenstelling met die volgende bewering van Drysdale (1989: 527), paragrawe af te staan aan die opname van etimologiese inligting van affikse nie: 
It is important to distinguish just what is meant by, and what is expected of, a dictionary etymology. Strictly speaking, the mere citing of a source word or source language is not sufficient, for the business of an etymology is to trace the development of a word, through its major changes of form and meaning $[\ldots]$.

Die etimologiese inligting kan in ' $n$ vertalende woordeboek bloot die aanduiding van die brontaal wees, byvoorbeeld $L$. vir Latyn, asook die oorspronklike Latynse affiks of woord en die betekenis in Afrikaans of Engels - afhangende daarvan in watter taal die vertaalekwivalent voorkom.

Volgens Oxford Dictionary of English Etymology (1966) het die prefiks predie volgende herkoms:

pre- prī, pri, pre- (e.g. in predicate, preface, premiss, preposition, presage, presence), prefix repr. F. pré- or its source L. præe-, later pré-i.e. the adv.prep. præ (of place, rank, time) before, in front, in advance [...]

Dit sou nie alleen oorbodige inligting verskaf nie, maar ook onbekostigbare ruimte opneem om só volledig op dié prefiks se herkoms in te gaan. Daarom behoort ' $n$ beperkte etimologiese aangawe soos [ $L$. præ voor] voldoende te wees. Svensén (1993: 91) het gelyk wanneer hy sê: "It is important to specify the meanings of the original word in such a way that the connection with the present-day meaning is clear [...]". Die etimologie het ' $n$ ondersteunende funksie wat naas die vertaalekwivalent bydra tot die verheldering van die huidige betekenis van die affiks. Vir die omvang van 'n sinchroniese vertalende woordeboek hoef die leksikograaf net so ver op die etimologie van 'n leksikale item in te gaan as wat nodig is om die betekenis duidelik te maak. In die geval van deursigtige affikse is dit nie nodig om etimologiese inligting aan te dui nie, omdat sodanige affikse hulleself verklaar.

\section{Uitspraak, klem en sillabeverdeling}

Beide TW en GW laat na om affigale lemmas van uitspraakleiding te voorsien. In die geval van leksikale lemmas word leiding wel verskaf, maar dit is beperk tot die aanduiding van die hoofklem in meersillabige lemmas. Dit is een van die onmisbare inligtingstipes wat verál in 'n vertalende woordeboek tuishoort, omdat die gebruiker van so ' $n$ woordeboek juis ten minste met een van die twee tale van die woordeboek minder bekend is: ' $n$ Groot probleem vir leksikograwe is om te besluit volgens watter stelsel uitspraak aangedui moet word. Sommige voel dat die reeds bestaande fonetiese transkripsiemetode meer volledig is en dus veral geskik sal wees in tweetalige woordeboeke, terwyl ander weer aandring op ' $n$ fonemiese stelsel, wat vir die taalkundig ongeskoolde gebruiker meer toeganklik kan wees en nie so tegnies is nie (Al-Kasimi 1977: 37-38). 'n Fonemiese transkripsie dui die verskillende foneme aan waaruit 'n lemma 
bestaan, sonder om die moontlike allofoniese variasie aan te dui, terwyl 'n fonetiese transkripsie wél vir hierdie verskille voorsiening maak. In woorde soos klein en kaart word die foneem $/ \mathrm{k} /$ as [k] uitgespreek. In ander klankomgewings, byvoorbeeld kleintjie en hondjie, word die foneem / $/$ as [c] uitgespreek. 'n Fonemiese transkripsie sal nie vir hierdie verskille voorsiening maak nie, terwyl 'n fonetiese transkripsie wel 'n onderskeid sal tref.

Watter stelsel ook al gekies word, uitspraakinligting is van groot belang in die vertalende woordeboek. Veral ten opsigte van affikse is dit onontbeerlik, omdat hulle in verbinding met verskillende stamme kan optree en dit hul uitspraak kan beinvloed. Die transkripsie moet op die lemma gerig wees, byvoorbeeld in die LGS waar die affigale lemma as polisemiese item opgeneem is, maar in al die gevalle dieselfde uitspraak het:

pro- [prəu] in Zssgn: 1. pro ..., ... freundlich, z.B. -German; 2. stellvertretend, Vize ..., Pro ...; 3. vor (räumlich u. zeitlich).

'n Stelsel van fonetiese transkripsie soos die International Phonetic Alphabet (IPA) behoort in Afrikaanse vertalende woordeboeke gevolg te word. Dit bied 'n vollediger weergawe van die allofoniese variasie in woorde en is daarom meer verteenwoordigend van werklike taalgebruik.

\subsection{Uitspraak}

In WAT IX word uitspraakleiding in die artikelgleuf direk na die lemmateken verskaf, byvoorbeeld -logie [loxi/luxi]. Die IPA word met groot sukses gebruik met ' $n$ volledige toeligting van die stelsel in die voorwoord. Die vertalende leksikograaf het egter 'n moeiliker taak, aangesien die vertaalekwivalente dikwels vir die gebruiker onbekend is en hulle uitspraak vir hom van groot belang is. Daarom sou beide lemma en vertaalekwivalent van uitspraakinligting voorsien kon word. Die toepassing van die omkeerbaarheidsbeginsel lei dan daartoe dat een leksikale item op twee plekke getranskribeer word. Waar lemma en vertaalekwivalent dieselfde uitgespreek word, hoef die leksikograaf nét die uitspraakleiding van die lemma te verskaf en 'n struktuurmerker soos die diamantteken kan aangewend word om vir die gebruiker aan te dui dat die uitspraak van die vertaalekwivalent dieselfde is as dié van die lemma, byvoorbeeld (A-E): eks- [eks] tex-, en (E-A): -a [a] - a.

Dit is belangrik dat die leksikograaf uitspraakleiding gee ten opsigte van die optrede van die affiks in 'n afleiding - onder andere deur gebruik te maak van voorbeeldmateriaal soos eenwoordsitate. Die uitspraak van die affiks moet uit die voorbeeldmateriaal blyk. Dit kan aan die hand van die volgende artikel in die LGS geillustreer word waar die twee polisemiese waardes van re- twee verskillende uitsprake het: 
re- in Zssgn 1. [ri:] wieder, noch einmal, neu: reprint, rebirth; 2. [rI] zurück, wider: revert, retract.

In hierdie artikel word die voorbeeldmateriaal ingespan om leiding te gee oor die lemma se gebruiksvoorbeelde. Dit is 'n geskikte adresseringsprosedure deurdat dit aan die hand van die voorbeeldmateriaal geskied en daar met min ruimte baie inligting verskaf word.

\subsection{Klem}

'n Ander hulpmiddel wat veral ook in vertalende woordeboeke 'n groot aanwins kan wees, is die aanduiding van die hoofklem van afleidings. Die klem van die affiks word beinvloed deur die stam waarmee die affiks verbind. Die hoofklem van afleidings word reeds in die artikels waarin hulle as lemmas optree, aangedui en dit sou dus 'n duplisering van inligting meebring om dit weer in die artikel van die affigale lemma te gee.

Die ruimte wat deur klemaanduiding in beslag geneem word, is relatief min in vergelyking met vertaalekwivalente of voorbeeldmateriaal. Daarom behoort die klem ook in die voorbeeldmateriaal van affiksè aangedui te word, sodat die woordeboekgebruiker liewer 'n té volledige as 'n gebrekkige uitspraakleiding kry. Klemaanduiding sou byvoorbeeld soos volg in die artikel van her- kon geskied:

her- $[\ldots]$ re- $[. .$.$] herkies', her'kou, herlei'.$

Hoewel die voorbeelde wat in die artikel van her- opgeneem is, ook in die makrostruktuur van die woordeboek met klemaanduiding voorkom, is dit vir die woordeboekgebruiker ' $n$ te omslagtige proses om die lemmas van elkeen op sy alfabetiese plek in die woordeboek na te slaan.

\subsection{Sillabeverdeling}

Nog 'n nuttige hulpmiddel wat grootliks in Afrikaanse vertalende woordeboeke ontbreek, is die aanduiding van die sillabeverdeling van meersillabige woorde. Dit behoort ook veral op die voorbeeldmateriaal van toepassing gemaak te word, omdat affikse dikwels op sigself monomorfemies is. So kan by die afleidings beoordeel (A-E) of revaccinate (E-A) as voorbeeldmateriaal by be- en re- onderskeidelik die onderskeie sillabes in die woorde deur die mer-

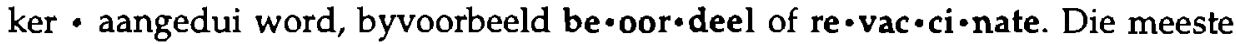
vertalende woordeboeke bied hierdie inligting in die makrostruktuur van die woordeboek aan onder die afleiding waarin die affiks optree. Dit kan aan die hand van die artikel van non- in Van Dale Groot Woordenboek: Engels-Nederlands (1989) geillustreer word: 
non- [non $\|$ nan] 0.1 non- $\Rightarrow$ niet(-) [...] 1 non-aggression non-agressie; nonflammable onbrandbaar.

non·ag・gres·sion $[\ldots]$

Dit blyk uit die artikel van non- dat die voorbeeldmateriaal nie bewerk word nie, dit wil sê dat daar nie fonetiese transkripsie, klemaanduiding of sillabeverdeling in die voorbeeldmateriaal aangedui word nie. Wat wel gebeur, is dat die voorbeeldmateriaal, byvoorbeeld die woord nonaggression, in die makrostruktuur van die woordeboek opgeneem word en dan as lemma van die nodige uitspraakleiding voorsien word. Die lemma nonaggression word getranskribeer as ['nona'gre [ $\mathrm{n} \|$ 'nan-] terwyl nonaggression nie as voorbeeldmateriaal onder die affigale lemma non- van uitspraakinligting voorsien word nie. Die klem word ook slegs in die transkripsie van nonaggression aangedui, en nie by die voorbeeldmateriaal van die affigale non- nie.

Daar behoort op dieselfde manier te werk gegaan word om voorbeeldmateriaal van uitspraakleiding te voorsien, as wat dit in die makrostruktuur van die woordeboek gedoen word. Dit bring weliswaar 'n duplisering van inligting mee, maar dit gaan 'n vollediger beeld aan die gebruiker verskaf en hom help om vinniger by die verlangde inligting uit te kom. In plaas daarvan dat die gebruiker die afleiding wat as voorbeeldmateriaal by die affiks optree, weer in die makrostruktuur moet gaan naslaan, is die inligting onmiddellik beskikbaar.

\section{Grammatikale inligting}

Die woordsoortelike kategorie van woordlemmas word in beide TW en GW baie getrou aangedui. Dit word naamlik, waar van toepassing, in die eerste gleuf na die lemma gedoen, byvoorbeeld

aanbou $n$.

aanbou (s)

waar aanbou die lemma is en $n$. en (s) die afkortings vir noun en selfstandige naamwoord onderskeidelik.

Met betrekking tot die affigale lemmas is daar groot inkonsekwentheid wat betref die benoeming asook die artikelposisie waarin dit voorkom. Affikse behoort nie tot ' $n$ woordsoortelike kategorie soos woorde nie, maar kan wel volgens hulle morfologiese kategorie geklassifiseer word, naamlik prefikse of suffikse. Dieselfde geld vir die benoeming van stamlemmas, naamlik stamme. Hierdie leksikale kategorieë kan dieselfde artikelgleuf beset as dié van woordsoorte by leksikale lemmas, direk na die lemma of die fonetiese transkripsie.

GW benoem die meeste van sy subleksikale lemmas glad nie. Ander is verkeerdelik benoem, byvoorbeeld die tegnostam peri ${ }^{2}(E-A)$ en die stam step $={ }^{2}(\mathrm{E}-\mathrm{A})$ word altwee as (pref) aangedui. TW, op sy beurt, benoem ook nie 
affikse baie konsekwent nie. Hy is egter meer korrek in sy benoeming as GW, deurdat die affikse wat wél benoem is, byvoorbeeld her= $(A-E)$ en wan= $(A-E)$, die juiste benaming van prefix het.

Die woordeboeke wat in hierdie artikel bespreek word, volg in hul benoeming die korrekte metode deur die morfologiese kategorie aan te dui in die gleuf wat elders daarvoor gebruik word, naamlik direk na die lemma. Oor hierdie stelsel is daar nie altyd sekerheid nie, omdat sommige woordeboeke - soos die Engelse COBUILD (1991) - dit soms in die kantlyn gee. COBUILD is weliswaar ' $n$ aanleerderwoordeboek en kom die gebruiker in hierdie geval tegemoet. Dit behoort egter in die eerste gleuf na die lemma gedoen te word, sodat dit 'n eenheid vorm saam met die res van die woordeboekartikel.

\section{Slot}

Dit blyk uit hierdie artikel dat die mikrostrukturele bewerking van affigale lemmas in TW en GW nie voldoende is nie. Soos die betrokke woordeboeke affikse tans hanteer, vervreem dit die gebruiker eerder as om vir hom/haar tot hulp te wees: Daar moet nog heelwat navorsing op hierdie terrein gedoen word. 'n Ondersoek na ingevoegde teks en die waarde wat dit kan inhou vir die mikrostrukturele bewerking van affigale lemmas (maar ook vir ander subleksikale lemmas), is onder andere een van die aspekte wat 'n verdere ondersoek noodsaak. Dit blyk ook uit die artikel dat, deur affikse as deel van die leksikon te beskou en affigale lemmas gevolglik soos volwaardige lemmas te behandel (soos wat die geval is met leksikale lemmas), die betrokke woordeboeke reeds 'n groot bydrae sal lewer tot ' $n$ vollediger inligtingsoordrag.

\section{Bronnelys}

\section{Woordeboeke}

Bosman, D.B., I.W. van der Merwe en L.W. Hiemstra. 1984. Tweetalige Woordeboek/Bilingual Dictionary. Kaapstad: Tafelberg.

Du Plessis, M. 1993. Tweetalige Aanleerderswoordeboek/Bilingual Learner's Dictionary. Kaapstad: Tafelberg.

Kritzinger, M.S.B., P.C. Schoonees en U.J. Cronjê. 1987. Groot Woordeboek/Major Dictionary. Pretoria: J.L. van Schaik.

Louw, J.P. en E.A. Nida. 1989. Greek-English Lexicon of the New Testament, Volume 1. Kaapstad: Bybelgenootskap van Suid-Afrika.

Martin, W. en G.A.J. Tops (Hoofreds.). 1991. Van Dale Groot Woordenboek: Engels-Nederlands /. Nederlands-Engels. Utrecht: Van Dale Lexicografie.

Messinger, H. 1988. Langenscheidts Großes Schulwörterbuch Englisch-Deutsch/Deutsch-Englisch. Ber-lyn: Langenscheidt.

Odendal, F.F. (Red.). 1994. Verklarende Handwoordeboek van die Afrikaanse Taal. Midrand: Perskor. 
Onions, C.T. (Red.). 1966. The Oxford Dictionary of English Etymology. Oxford: Clarendon Press. Sinclair, J. (Hoofred.). 1991. Collins COBUILD English Language Dictionary. Londen: Collins. Van Schalkwyk, D.J. (Hoofred.). 1994. Woordeboek van die Afrikaanse Taal, Deel IX. Stellenbosch: Buro van die WAT.

\section{Ander bronne}

Al-Kasimi, A. M. 1977. Linguistics and Bilingual Dictionaries. Leiden: E.J. Brill.

De Wet, G. 1998. Die makrostrukturele vergestalting van affikse en tegnostamme in Afrikaanse vertalende woordeboeke. Lexikos 8: 154-172.

Drysdale, P.D. 1989. Etymological Information in the General Monolingual Dictionary. Hausmann, F.J., O. Reichmann, H.E. Wiegand en L. Zgusta. (Reds.). 1989-1991: 525-530.

Geeraerts, D. 1986. Woordbetekenis. Leuven: Uitgeverij Acco.

Gouws, R.H. 1989. Leksikografie. Pretoria / Kaapstad: Academica.

Hausmann, F.J., O. Reichmann, H.E. Wiegand en L. Zgusta (Reds.). 1989-1991. Wörterbücher: Ein internationales Handbuch zur Lexikographie / Dictionaries: An International Encyclopedia of Lexicography / Dictionnaires: Encyclopédie internationale de lexicographie. Berlyn/New York: Walter de Gruyter.

Leech, G.N. 1981. Semantics: The Study of Meaning. Harmondsworth: Penguin.

Louw, P.A. en R.H. Gouws. 1996. Lemmatiese en nielemmatiese adressering in Afrikaanse vertalende woordeboeke. S.A. Tydskrif vir Taalkunde 14(3): 92-100.

Lyons, J. 1981. Language, Meaning and Context. Londen: Fontana.

Svensén, Bo. 1993. Practical Lexicography. Oxford: Oxford University Press. 


\title{
Lost in the Labyrinth of Lexicogra- phy - Labours of a Lawyer
}

\author{
Marthie Jansen, Department of Criminal and Procedural Law, University of \\ South Africa, Pretoria, Republic of South Africa
}

\begin{abstract}
The work of the Centre for Legal Terminology in African Languages comprises the compilation of a legal dictionary where various legal terms are defined and translated into the different indigenous African languages. During the first phase of the Centre's work a selection is made of English terms in the domains of criminal law and criminal procedural law. These terms are then defined and translated into the first target language, namely Afrikaans. This article deals with the lexicographical and legal problems encountered by the Centre during this phase as seen from a lawyer's perspective. On the lexicographical side the problems relate to demarcating the domains, determining a target group, the availability or lack of sources and indicating how the Afrikaans translation helps in establishing the correct meanings of terms. The legal problems encountered relate mostly to copyright, but brief reference is also made to the aspect of civil liability which might arise from the use of the completed dictionary.
\end{abstract}

Keywords: CENTRE FOR LEGAL TERMINOLOGY IN AFRICAN LANGUAGES, COPYRIGHT, CRIME, CRIMINAL LAW, CRIMINAL PROCEDURAL LAW, DEFINITION, DICTIONARY, INDIGENOUS AFRICAN LANGUAGES, LAW, LEGAL LIABILITY, LEGAL TERM, LEGAL TERMINOLOGY, LEXICOGRAPHY, PRODUCT LIABILITY, TRANSLATION

Opsomming: Verdwaal in die doolhof van leksikografie - die stryd van 'n regsgeleerde. Die werk van die Sentrum vir Regsterminologie in Afrikatale behels die samestelling van 'n regswoordeboek waarin verskillende regsterme gedefinieer en dan vertaal word in die verskillende inheemse Afrikatale. Gedurende die eerste fase van die Sentrum se werksaamhede word 'n keuse van Engelse terme op die terrein van strafreg en strafprosesreg gemaak. Hierdie terme word dan van definisies voorsien en in die eerste doeltaal, naamlik Afrikaans, vertaal. Hierdie artikel handel oor die leksikografiese en regsprobleme wat deur die Sentrum ervaar is gedurende hierdie fase van die werk, soos gesien vanuit ' $n$ regsgeleerde se perspektief. Aan die leksikografiese kant hou die probleme verband met die afbakening van die terreine, die bepaling van ' $n$ teikengroep, die beskikbaarheid of gebrek aan bronne asook ' $n$ aanduiding van hoe die Afrikaanse vertaling meehelp om die korrekte betekenis van terme te bepaal. Regsprobleme wat ervaar is, hou grotendeels verband met outeursreg, maar daar word ook kortliks verwys na die aspek van siviele aanspreeklikheid wat mag voortvloei uit die gebruik van die voltooide woordeboek.

Sleutelwoorde: DEFINISIE, INHEEMSE AFRIKATALE, LEKSIKOGRAFIE, MISDAAD, OUTEURSREG, PRODUKTEAANSPREEKLIKHEID, REG, REGSAANSPREEKLIKHEID, REGS- 
TERM, REGSTERMINOLOGIE, SENTRUM VIR REGSTERMINOLOGIE IN AFRIKATALE, STRAFPROSESREG, STRAFREG, VERTALING, WOORDEBOEK

\section{Introduction}

In the late 1980 s the idea arose to make legal terminology more accessible to the average South African citizen. At that stage nobody involved in the process realised what really lay ahead. The aim was somewhat idealistic: to compile a dictionary containing various legal terms with their definitions and at the same time to translate these terms and definitions into one or more of the various indigenous African languages. The Centre for Legal Terminology in African Languages was established to organise and co-ordinate the work. The background to the formation of the Centre, its objectives, working procedure and some of the original problems encountered, were related in an earlier edition of Lexikos and will not be repeated here. It is, however, necessary to refer briefly to the various stages in the working procedure as mentioned by Alberts (1997: 184).

The first phase comprised the compilation of lists of legal terms in English in the domains of criminal law and criminal procedural law. Definitions were then provided for terms with a specific legal meaning and, where necessary, examples of how the terms should or could be used, were given. The English terms, their definitions and examples were then translated into Afrikaans.

During the second phase the English-Afrikaans term list was edited to conform to terminological and terminographical standards, entered into a computer and adapted in accordance with the requirements of the database system.

The third phase involved the translation of the various terms and their definitions and examples into an indigenous African language. At present the Centre is working on Sepedi but the idea is to extend the work to other indigenous languages during the fourth and further phases of the work.

Each phase in the work process has unique problems and pitfalls, requiring caution by the researcher. In this article an attempt is made to examine the first phase of the work where terms are selected and defined in the source language and simultaneously translated into Afrikaans, the first target language. During this phase law and lexicography inevitably overlap. For the sake of convenience, however, this article will first deal with the problems that are of a more lexicographical nature (as seen from a lawyer's perspective), and then refer briefly to some problems also encountered in the legal field. The information and impressions provided are those of a lawyer from the viewpoint of a lawyer. 


\section{Problems of a Lexicographical Nature}

\subsection{Selection of Legal Terms in the Source Language}

As stated by Alberts (1997: 183) "at this stage, the Centre for Legal Terminology in African Languages only concentrates on providing African language equivalents in the subdomains of criminal law and criminal procedural law because of the dire need in these legal fields".

Although such a demarcation seems simple and straightforward enough, it provided the first obstacle to be overcome in the work of the Centre, namely determining the ambit of the fields of criminal law and criminal procedural law. In its most simplistic form criminal law can be described as that "branch of the law that specifies what conduct constitutes a crime and establishes appropriate punishment for such conduct" (Handler 1994: 119). Criminal procedural law then, according to Snyman (1995: 5 ), is "the procedure by which alleged criminals are brought before court and tried for their alleged offences". From these descriptions it is immediately evident that the concepts of "crime" and "offence" are crucial. For a layperson the terms are associated with bloodshed, murder, rape, robbery, theft, et cetera, as well as the accompanying gory details.

From a lawyer's perspective the scene is somewhat different. A lawyer starts from the basic premise that the function of the law is to solve social conflicts and thereby to create order in a community (Hosten et al. 1977: 16). This is done by defining the interests of people, balancing them with those of others and harmonising them so that one person's interests does not encroach on another's. Whenever the legal equilibrium is disturbed, the legal system attempts to restore it by attaching enforceable consequences to the conduct that originally disturbed the harmony. This compulsory restoration of the disturbed legal position is called "retribution" and can take the form of punishment or of compensation for damages caused. Crimes are forms of conduct that are not only committed against the individual, but disturb the public order as well. Mere compensation of the injured individual does not provide adequate retribution. The retribution provided has to satisfy the needs of the community. Punishment by the state as representative of the community is therefore the most appropriate solution to the disturbed legal position. At this stage it ought to be clear that from this perspective virtually any act has within itself the seed to develop into a crime. This means that the boundaries of the field of criminal law are virtually indeterminable.

This is why one finds that sometimes a crime is defined in such a way that the definition seems all-encompassing, namely as "an act or omission which, whether or not it is morally wrongful or is deemed a wrong to an individual and civilly actionable by him for compensation from the harm done to him, is legally deemed an offence against the State or the community or the public and is punishable, as a deterrent to the offender and others, for the sake of public 
order, peace and well-being and in the interest of society" (Walker 1980: 313). In nonlegal dictionaries, such as Hanks $\left(1989^{2}: 369\right)$, the definition stands out for its brevity: "an act or omission prohibited and punished by law". In practice lawyers apply a more conservative approach by retaining only those elements in the definition that are absolutely necessary. Thus a crime is generally defined as "an unlawful blameworthy human act or omission prohibited and punished by law".

For the sake of those readers unfamiliar with the law, a brief explanation of the meaning of the various terms in this definition follows below.

\section{Human act or omission}

From what has already been said, it is evident that the legal equilibrium can only be disturbed by some form of human conduct. A crime must therefore consist of an act. Mere thoughts or even decisions to commit a crime are not punishable (Snyman 1995": 26). The law does not limit the meaning of "act" to positive conduct only, but includes negative conduct as well. By negative conduct is understood the failure to act where a person is legally obliged to do something (Snyman 1995:26) - in legal terminology known as an omission. A good example of this is the failure to stop at a red traffic light.

\section{Prohibited or punished by law}

The requirement embodied in this phrase is called "the principle of legality". It has its origin in a well-known Latin maxim nullum crimen sine lege which means "without a law no crime can exist". According to this principle, a person will only be liable if his/her conduct was considered a crime by the legal system at the moment it took place. A person cannot be found guilty and punished by a court merely because the presiding judge is of the opinion that the particular conduct of which the person is accused, is immoral or damaging to the community or that the culprit "deserves" to be punished. A well-defined legal prohibition must exist indicating exactly what type of conduct is not permissible. In short, this means that the man/woman in the street must be able to determine what is expected from him/her.

This principle has certain serious consequences for the compilation of a legal dictionary, as will be explained below. At this stage it is important to note that we do not have a codified criminal law system in South Africa. This means that we do not have a specific written source listing each and every form of conduct that is regarded as a crime.

To determine what constitutes criminal conduct in South Africa, one has to consult two sources, viz. common law and statutory law. Common-law crimes encompass those crimes that have existed within the community from time immemorial and which relate to conduct that has traditionally been 
regarded as loathsome. They have no specific date of birth, nor can one ascribe their origin to a specific government. Everybody within a given community is normally aware of the fact that these forms of conduct are not acceptable. Common-law crimes therefore form part of our legal inheritance and legal tradition. Examples would be crimes such as murder, theft, assault, rape, et cetera. Common-law crimes developed from the needs of the community. It is therefore logical that changing requirements can lead to changes in the definitions of these crimes in order to adapt them to altered circumstances. Such adaptation cannot however be done indiscriminately when the law is applied in court, as it would violate the principle of legality and members of the public would not know which forms of conduct should be avoided. An example illustrates this: theft has traditionally been defined as "the wrongful taking of any movable property without the consent of the owner, with the intention on the part of the taker to appropriate it" (Milne et al. 1951': 813). In terms of this definition one requirement was that the article stolen should be something that could be physically removed. Banknotes and coins comprise such articles and could therefore be stolen. Due to the development of technology and computer systems, it is nowadays possible to transfer credit from one bank account to another simply by altering various entries in the records. In principle the effect is precisely the same as if money had physically been removed from one person's possession and handed to another. The legal system merely adapted the existing definition to include these forms of conduct under the definition of theft. Common-law crimes can therefore make provision for situations which are not yet known and a prospective criminal can be forestalled. The only problem from the viewpoint of a dictionary compiler is to state in words what the collective mind of the community understands the crime to be. This is why one finds that more recent definitions of common-law crimes are normally long and burdensome, as is evidenced by the latest definition of theft given by Snyman (1995': 445):

"A person commits theft if he unlawfully and intentionally appropriates movable, corporeal property which

(a) belongs to, and is in the possession of, another;

(b) belongs to another but is in the perpetrator's own possession; or

(c) belongs to the perpetrator but is in another's possession and such other person has a right to possess it which legally prevails against the perpetrator's own right of possession

provided that the intention to appropriate the property includes an intention permanently to deprive the person entitled to the possession of the property, of such property."

Another problem with regard to the common law is that adaptations cannot occur ad infinitum. Somewhere a line has to be drawn. If one extends the definition of theft to include theft of credit, would this imply that one could extend it even further to include an abstract concept such as the theft of electricity or even further still, to include the theft of information from a computer 
network? If certainty is also a requirement for a legal system to be successful, mere extensions cannot be regarded as the ultimate solution. Other arrangements have to be made.

It is here that the state enters into the picture in the guise of the legislature. As and when developments create the need for further forms of conduct to be declared crimes, the legislature merely determines this in an Act of Parliament. Because the new crime created in the Act is as yet unknown to the community, the wording of the Act must state precisely what is prohibited. An interpreter of the statute is limited in his or her interpretation by the wording of the Act. What is problematic about such a statutory definition is the fact that criminals are normally one step ahead of the law. As these new definitions have not yet stood the test of time, loopholes are usually easy to find, with the result that such definitions have to be amended time and again. Where the definition of such statutory crimes are incorporated in a dictionary, the precise wording, regardless of how comprehensive it may be, must be provided as well as reference to the specific statute where the definition appears. The compilers of the dictionary furthermore run the risk that such definitions may become outdated even before their work is published. A well-known example is the case relating to Communism. The South African Communist Party was declared an unlawful organisation in terms of section 4 of the Internal Security Act 74 of 1982. Promoting the aims of this organisation was at that stage considered a punishable crime. Due to the change in political environment, the SACP was declared lawful and the bulk of the Internal Security Act was repealed because it no longer reflected the views of the ruling government. A definition which regards the promotion of the aims of Communism as a crime, would therefore be outdated.

An interesting example encountered by the Centre whilst defining various crimes was the case of "bigamy". Traditionally bigamy has been regarded as a common-law crime in South Africa and was also punished as such, although exceptions were made for people married in terms of indigenous or customary law. The new Constitution of the Republic of South Africa 108 of 1996 had an impact on this view. Provision is made in the Constitution for the development and application of indigenous (customary) law alongside the existing common law (s 39(2)). It is also provided that there may not be any form of unfair discrimination against individuals or groups of people on the ground of race, gender, et cetera (s 9). One can now argue that if one man in a country has the right to have more than one wife, whereas another man in the same country may have only one, this constitutes unfair discrimination. (I refrain from stating against whom the discrimination is exerted.) In this transitionary period how should one define bigamy in an explanatory dictionary? Is it "marrying more than one wife which is regarded as a crime by a certain section of the community", or is it "having more than one wife which is an acceptable practice for part of the community" or should one rather exclude all references to discrimination by stating that bigamy means "the criminal conduct or noncriminal 
conduct (depending on the type of marriage that was solemnised) of a person who has more than one marriage partner". At least such a view includes homosexual relationships and makes provision for those feminists who are of the opinion that women should also have the right to be married to more than one husband!

\section{(3) Unlawfulness}

A third requirement that must be present before conduct will be regarded as criminal, is the aspect of unlawfulness. The mere fact that an act corresponds with the prohibition in the definition of the crime, does not necessarily mean that such conduct is also unlawful. Consider for example the case where a speed limit of 120 kilometres per hour is set. An emergency occurs and the accused, having no other alternative, exceeds the speed limit to take an ill person to hospital for emergency treatment. Our inherent feeling of what is just and acceptable clearly implies that such conduct should not be regarded as criminal and punishable. Unlawfulness therefore relates to society's views and convictions of what is legally acceptable and right. The moment there is a valid reason for a person to transgress a legal rule, the views of society are that such a person must be excused from liability. Over the years certain of these "reasons" have occurred time and again. They are now so well-defined that people tend to regard them as a predetermined number (numerus clausus). The presence of such a "reason" automatically excuses a person from liability for conduct which would otherwise be regarded as criminal. Examples of such reasons are acting in self-defence, cases of necessity, where consent was given, where somebody acts on the order of a superior, or has a right to chastise his/her children. These "reasons" cancel the unlawfulness of a person's conduct and are known in legal terminology as grounds for justification.

\section{(4) Blameworthiness}

The mere fact that a person's act corresponds with the prohibition stated in a particular definition and is at the same time unlawful, does not necessarily mean that the wrongdoer is without further ado criminally liable. To be guilty of the commission of the crime, the wrongdoer must also be to blame or, as it is termed in law, "fault" must be present. In its technical legal meaning "fault" relates to the blameworthy state of mind of a person who commits an unlawful act. According to Snyman $\left(1995^{3}: 28\right)$ "the focus shifts from the act to the actor, that is, X himself - his personal abilities, knowledge, or lack thereof". In terms of the law an offender can be held responsible for his conduct only if it is reasonable to expect him/her to avoid, renounce or stop committing the unlawful act. A mentally ill person or a five year old child who acts unlawfully, cannot be blamed for their actions because they cannot be expected to behave lawfully. 
Blameworthiness is therefore dependent on a person's accountability (i.e. his/her mental abilities or state of mind which enables him/her to distinguish between right and wrong and to act accordingly) and his/her attitude (that is whether he/she has acted intentionally or negligently).

Only conduct where all four above-mentioned elements are present can be regarded as criminal and falls within the ambit of criminal law. The question that now arises, is whether the compiler of a dictionary should, when defining a crime, mention all four elements in each definition. Can one limit the definition by merely stating the prohibited form of conduct and assume that the reader will automatically accept that the conduct has to be unlawful and blameworthy as well as prohibited in a specific well-defined legal prohibition? Should one mention the source where the prohibition can be found? As will be indicated later, the legal implications of this decision can be far-reaching.

To answer the questions stated above, it was necessary to decide for which target group the Centre's proposed dictionary would be appropriate.

\subsection{Determining a Target Group}

The moment we started working on the dictionary, it became evident that there was one important aspect which had been overlooked - there were at that stage only a few legal dictionaries available in South Africa that could be used as basic sources. For the purposes of our work, however, all had serious shortcomings. When talking about legal dictionaries, every lawyer will immediately mention the Trilingual Legal Dictionary by V.G. Hiemstra and H.L. Gonin. The name of this work is, however, a complete misnomer. It is not trilingual in the sense that each term provided is translated into three different languages. This work actually consists of three sections, each of which is bilingual. The various sections are English-Afrikaans, Afrikaans-English and then a selection of Latin terms and phrases which are translated into Afrikaans and English. Definitions are only provided in a few selected cases where terms might be problematic.

The Jurisdiese Woordeboek/Juridical Dictionary of C.A. Marais consists of a list of English legal terms translated into Afrikaans, and vice versa, without any explanations or definitions. The majority of terms provided are already incorporated in Hiemstra and Gonir's work so that this work cannot really serve as a separate primary source.

A Dictionary of Legal Words and Phrases by R.D. Claassen is also available. It is, however, not appropriate for the work of the Centre as it does not provide a broad or general definition of each legal term but merely indicates where reference was made to the specific term in legislation or where it was considered in court decisions.

The Woordeboek van Regs- en Handelsterme by J. Smuts and I.J. Smuts is an Afrikaans-English legal dictionary which also provides definitions for the majority of terms incorporated in the work. Its usefulness is once again restricted 
- this time due to the fact that the source language is Afrikaans (which is not understood by many of the inhabitants of the country) and the domain limited to legal terms used in commerce.

Other South African legal dictionaries are outdated - all of them date back to the fifties and early sixties - and none of them cover the same field or follow the same approach that we had in mind. At this stage of our work it became evident that an enormous need existed for the type of work the Centre planned. Originally the target group that had been identified as prospective users of the dictionary, was limited to interpreters and translators. We became sure that, due to the lack of sources, this target group would in all probability be far greater than envisaged. A dictionary such as the one we had in mind, would be suitable not only in the courts, but also for use by legal practitioners, compilers of legislation, law students and, last but not least, the man in the street.

Identifying such a broad target group immediately had an impact on our modus operandi. When a legal dictionary is aimed at lawyers only, a definition of a crime, for example, need not contain each element as explained above, but can be limited to the definition of the proscription alone. The definition of the proscription represents only one component of the total definition of the crime. It can be expressed negatively as the definition of the crime minus the requirements of unlawfulness and fault. In the case of statutory crimes the requirement of unlawfulness is very seldom explicitly stated in the definition although it is nevertheless still an implied requirement. The blameworthiness and the form it may take, is in the case of statutory crimes often stated indirectly by means of synonyms or explanatory sentences such as the use of the word "knowingly" which would imply intention. A lawyer is also interested in knowing where to find the definition of a statutory crime for example in Act... of $19 .$. section... Additional information as to how the definition has been applied in practice and interpreted by the courts would also be useful. (This is the information supplied by Claassen $\left(1997^{2}\right)$.) Such information would be wasted on the layperson who is only concerned in determining what form of conduct comprises the crime. For example, the definition of theft given earlier is so technical and complicated that although it contains all possible elements a lawyer needs to know, it merely confuses the layperson and cannot be understood unless extensive further explanations are given.

Our only solution was to compromise. We therefore tried to simplify definitions in order to make them more understandable to the layperson but without sacrificing aspects which might also be important to a student of law. In the case of statutory crimes we decided to refrain from mentioning where in a statute a specific definition can be found. The reason for this approach is because statutes are often amended and referential information relating to statutes easily becomes outdated. Here we also decided to restrict the definition to the proscription as given in the relevant statute, but stated in a more simplified form. In the case of the common-law crimes all the elements comprising the specific 
crime are generally mentioned in the definition, especially the type of fault required, as this may differ (being either intention, negligence or faultless liability).

\subsection{Availability of Source Material}

The scarcity of South African legal dictionaries had a further impact on the work of the Centre. Although English is an international language and explanatory English dictionaries are freely available, this provided yet another drawback. Each English legal dictionary on the market reflects the legal system of its country of origin. British English dictionaries give the meanings of terms in England. Canadian English refers to Canadian law, American dictionaries give the meanings of legal terms in the United States, Australian dictionaries the Australian law system, and so forth. Although there is a correlation in the basic principles that apply in most of the legal systems in the Western world, details can differ considerably. The two major legal systems found in the West are the Common Law system applied in the Anglo-American countries and the Civil Law or Romano-Germanic system which was formed in continental Europe and to which South Africa belongs (David and Brierley $1978^{2}: 33$ ). The latter system has Roman law as its origin. In the case of South Africa the Roman law has furthermore been adapted and supplemented by Dutch law and English law to provide a unique South African law. Due to this uniqueness, definitions of terms used in other English-speaking countries do not necessarily correspond to those that apply in South Africa.

To return once again to the example given earlier of the well-known term "crime". The technical meaning of this term as it is generally used in South Africa, consisting of its four basic components, has already been given. Apart from the term "crime" one comes across a number of related terms such as "offence", "misdemeanour", "felony", "contravention", and "transgression". The question that now arises, is whether these related terms are precise synonyms of "crime" or whether there are shades of differences, and if so, how the terms should be distinguished. Various possibilities come to mind: the terms may all relate to "crimes" merely indicating various levels or degrees of seriousness; alternatively they may draw a distinction between different types of crimes on the ground of origin or development thus differentiating between criminal conduct which is of statutory origin and conduct prohibited in terms of customary common law. Students of law who are not aware of the basic differences between various legal systems which all use English as the language of communication, might fall into the trap of regarding a definition given in a British dictionary as being the same as the one used in South African law. Because the target group which the Centre had in mind for its magnum opus was so diverse, it was often necessary to refer to such finer distinctions. Sometimes we had to resort to extensive explanations, as the following quote from Snyman (1995: 7) which was used in the dictionary, illustrates: "In English law 
crimes were until 1967 divided into three categories, namely 'treasons', 'felonies' and 'misdemeanours'. 'Treasons' were more serious crimes than 'felonies', and 'felonies' more serious than 'misdemeanours'. This distinction used to be of importance in English law from a procedural point of view, and from the point of view of punishment, since lighter punishment was prescribed for 'misdemeanours' than for 'felonies', and for 'felonies' than for 'treason'. In 1967 this distinction was abolished in England by legislation but in the USA it still exists."

Other terms were not so easy to handle. The terms "crime" and "offence" for example are used by lawyers in an haphazard way, sometimes indiscriminately, other times intuitively in the correct context. When confronted, lawyers cannot give adequate reasons why one term was preferred to the other. The layman in this instance often thinks that "crime" refers to the more serious forms of criminal conduct such as murder, rape or theft whereas "offence" refers to less serious forms of criminal conduct such as the contraventions of municipal bylaws. Yet Snyman $\left(1995^{3}: 7\right)$ is of the opinion that there is no technical difference between a crime and an offence. However, it seems as if the practising lawyer tends to use the term "crime" for conduct considered as criminal in terms of the common law, whereas "offence" is used more generally to relate to statutory prohibitions. The reason for this differentiation can perhaps be sought in the fact that the Criminal Procedure Act 51 of 1977 - which lays down the procedures for the prosecution of crimes - uses the word "offence" throughout and defines it as "an act or omission punishable by law" (s 1).

A similar situation arises in respect of words such as "litigation", "action", "case" and "dispute". The compiler of the English/Afrikaans terminology lists has to be on the alert. A term which is not characteristic of the South African legal system, can easily slip through. This is even more so because, as was already mentioned, there are no criminal law dictionaries with definitions based on South African law available in the country. Nonlegal dictionaries seldom provide the finer nuances of meaning necessary to distinguish between synonyms or near synonyms. Ample use has therefore to be made of South African legal textbooks and this delays the work considerably. Where terms are particularly difficult to define, help is obtained from academics involved in the teaching of law. However, simplifying a definition without omitting some of its salient features remains extremely difficult.

Merely omitting those legal terms which are not applied in South Africa, is not always regarded as the best solution. The development of the world into a "global village", the development of communication technology and the availability of English and American films, videos and other forms of communication in the South African market has had the effect that certain legal terms which are strictly speaking not at all South African, have become part and parcel of our everyday speech. It is therefore necessary to include such terms in the 
dictionary, and to explain their meanings while indicating why they are not regarded as South African and what the correct South African equivalent is. The term "jury" for example, crops up so often that the average South African is under the impression that a jury system exists in this country although it was abolished in 1969. (By "jury" is meant, according to Coertze and Hiemstra (1947: 81), nine lay persons, drawn by lot, who sit in criminal cases as judges of fact, not of law.)

In English law a barrister is "a specialist consultant and pleader belonging to a class of lawyers that is given predominant rights of audience in superior courts" (Garner 1995": 99.) To rephrase, a barrister is an advocate admitted to the bar who might appear in court on behalf of suitors or defendants. He is distinguished from the attorney who draws the pleadings, prepares the testimony and conducts matters out of court. In the United States the term has no official meaning but is a popular synonym for "lawyer". In South Africa the acceptable term is "advocate".

Another term that is often heard in South African conversations is "first degree murder". It has its origin in American jurisdictions where a differentiation is made between first degree and second degree murder on the basis and gravity of the offence (Garner $1995^{2}: 259$ ). In the case of the former the intentional killing is "premeditated" whereas in the latter case the intentional killing occurs without "premeditation" (Handler 1994: 351). For a South African, the concept of "premeditation" is incorporated in the element of intention because the latter refers to the idea of having knowledge of the unlawfulness of one's conduct but nevertheless directing one's will towards attaining a desired result (Snyman 1995: 168).

In other instances identical terms are used in different legal systems but the meanings do not always correspond. The term "battery" would perhaps be a good example to use. In English law this term relates to "the unlawful beating or wounding of a person or mere touching in a hostile or offensive manner" (Hanks 1989': 130). In South Africa "battery" has a more limited meaning and relates to a type of assault that is committed persistently and intermittently, usually by a relative of the victim or by a person living in the same house. In this country, however, there is no crime of battery. The type of conduct mentioned in relation to this term is punished as assault (Jansen 1993: 202).

Due to the various problems mentioned here, the compilers of the sourcelanguage terminology list quite often found it easier to work with the Afrikaans equivalent of a term instead of the English original. In this way they were less likely to confuse the meanings applied in different countries. This is why the Afrikaans terminology had to be compiled simultaneously with the English. It could not be added later as a mere translation of the English. Formulating a definition in Afrikaans at least had the advantage that the end product on the English side was a true reflection of the South African view. 


\subsection{English-Afrikaans Translation}

However, the approach mentioned above had a serious disadvantage which caused a further stumbling block. Terms in one language do not always have precise equivalents in another language. The term in the source language is frequently broader or narrower in meaning than the term in the target language into which it is translated. This problem arose quite often as the Centre's dictionary is not limited to terms which occur only in the field of criminal law and criminal procedural law. There are also a number of what one can call "peripheral" terms. Such terms are generally used in a nonlegal sense but they also occur so often in the fields of criminal and criminal procedural law that they can just as well be classified as criminal law terms. These terms quite often have various meanings: some of them strictly related to criminal law, others of a more general nature. In the translation process from English to Afrikaans one finds that for each meaning attached to the English term a separate term might exist in the Afrikaans. To make things even more complicated the same might apply to the Afrikaans side. The Afrikaans translation of a term might therefore have additional meanings which are not incorporated in the English equivalent. In a normal dictionary where terms in one language are merely translated into another language, this phenomenon is not really problematic. However, the moment when a definition is also given for a term in the source language and the definition has to be translated and has to reflect the same meaning in the target language as well, problems are sure to arise. It was therefore inevitable that the definitions in source and target languages could not always be precise mirror images of one another. (The aspect mentioned in this paragraph had further consequences when it came to the writing of an appropriate computer program. It was the Centre's intention to create a database where a target language could be changed into a source language and vice versa and the compilators had to take this into account.)

An example might explain the situation better:

In the legal sense the term "enrol" normally has three distinct meanings depending on whether it is used with regard to a thing, a person or a lawyer. (It is interesting that a lawyer is regarded as neither a thing nor a person!) In the first instance "enrol" has the meaning of "to put on record" or "to record or note in a roll or list". In the second sense it means "to become or cause to become a member, to enlist or register" in other words the physical act of writing a person's name in a list or register (Hanks $1989^{2}: 508$ ). Where the term is used with relation to an attorney or advocate, it has the meaning of admitting them to the bar or side-bar. In Afrikaans the corresponding terms are "ter rolle plaas" when used in relation to a thing, "inskryf" or "werf" where it relates to placing a person's name on a register, and "toelaat" in terms of advocates and attorneys. All the Afrikaans terms can be used in other senses which differ from the ones in which they are used here. To mention just a few: the term "werf" can also relate to a yard around a building and the term "toelaat" to 
permit someone to do something. In this specific example the solution was quite easy: the additional meanings were merely omitted because they did not relate to criminal law. However, similar cases were not so easy to handle.

During this stage of the work, interesting aspects regarding language and the origin of words and terms also came to light. In English the word "government" is used to indicate the existing ruling party as well as the state itself (Hanks 1989': 659). Afrikaans on the other hand distinguishes between the two concepts. In Afrikaans the distinction is confirmed by the fact that the Government Gazette and a Government Notice are called "Staatskoerant" and "Goewermentskennisgewing" respectively. Why separate terms for a concept which seems the same? No existing dictionary could help and we had to refer to the original Dutch (Beets and Muller 1900: 494). It appears that the difference comes from the fact that the word "staat" is considered a neutral term without emotional value, whereas "goewerment" is politically coloured. (In the first indigenous language into which the terms were translated the differentiation found in the Afrikaans was maintained rather than the similarity existing in the English. From the Sepedi word "busa" which means "to govern", two nouns were derived, namely "pušo" for government and "mmušo" for state.)

\section{Legal Problems}

What has been said so far relates only to those problems which had direct bearing on terminology, lexicography and language. In the indirect sense there were other, possibly more important issues (from a lawyer's point of view) that also had to be taken into consideration. I call them indirect issues because they are strictly speaking not related to the work as such but are important prerequisites which must be kept in mind because they give rise to various legal consequences. In what follows, two of these side issues are considered namely the obligations flowing from copyright laws and the liabilities incurred by the creation of a new product.

\subsection{Copyright Issues}

A detailed exposition of the copyright requirements applicable to terminologists and lexicographers was given by Jooste and Alberts (1998: 123) in an article in the previous edition of Lexikos. The writers referred to "lexicographers and terminographers as being both creators of copyrightable products, and users of copyrighted products". As these two aspects go to the heart of copyright protection, I will refer briefly to both in so far as they are applicable when compiling the type of dictionary the Centre has in mind.

The law governing copyright in South Africa is regulated by the Copyright Act 98 of 1978 as amended. (This Act is based on an international agreement called the Berne Convention. It is however the legislation and not the 
international agreement that is the primary source for determining the legal principles that apply in this country.) Apart from the Act there are a number of court decisions which interpret various portions of the Act and provide precedents which can be relied on when copyright issues arise. The law governing copyright is extremely complex. I shall therefore attempt to explain some of the problems encountered in this regard by the Centre in layman's language and refrain from using the normal legalese used by lawyers.

The basic principle that applies in the case of copyright, is that a person who creates, something has a right of ownership over the article that he/she has created. In other words, the owner obtains a qualified monopoly over his/her creation which enables him/her to prevent the unsolicited copying of the work (Copeling 1978: 3). Although the idea of copyright protection is not to make the owner of the copyright rich, he/she obtains the financial benefit that results from his/her work (Dean 1998: 1-1). The various categories of works protected under the copyright laws include literary works. Strictly speaking it is better to refer to these as written works because the literary merit of the work is irrelevant (Dean 1998: 1-6; also see University of London Press Ltd $v$ University Tutorial Press Ltd 19162 Ch 601 608). Books, articles, encyclopaedias and dictionaries are all regarded as written (or literary) works (s 1(1) of the Copyright Act 98 of 1978 as amended) and are protected under the Act. This aspect is important to the compiler of a new dictionary as these are the sources normally consulted when compiling the new work.

\subsubsection{The use of existing sources during the compilation of a new dictionary}

As stated above, copyright gives the copyright owner of a work the sole right to exploit his/her work commercially for a certain period. It is as if the owner obtains a bundle (Dean 1998: 1-81) of exclusive, overlapping rights. Actions by outsiders which diminish these rights, are regarded as infringements. Broadly speaking, one can say that infringement of another's copyright takes place when there is unauthorised copying or unauthorised commercial exploitation of a work (Dean 1998: 1-37). Although it is not stated as such in the Act, infringement can only occur when there has been actual copying of a substantial portion of another's work (Copeling 1978: 24, 25) without the copyright holder's permission. The prohibition seems simple and straightforward enough but it leaves the door open for diverse interpretations.

The first question that arises, is what is meant by actual copying. It is easy to determine that an identical copy is a case of actual copying, for example a photostat copy of a printed book. However, the issue becomes clouded when the format of the original is changed to some degree so that the copy is not a precise replica of the original. Generally speaking, lawsuits involve situations where protected material has either been used commercially or altered. Where a work is transformed in such a manner that the original or substantial features of the original remain recognisable, it is called either a reproduction or an 
adaptation depending on how the original was transformed. Both "reproducing the work in any manner or form", and "making an adaptation of the work" are regarded as comprising actual copying and therefore constitute infringement (s 6 of the Copyright Act). For our purposes it is important to note that the translation of a literary work is specifically mentioned in the Copyright Act as being a form of adaptation (s 1(1)).

Secondly, even where actual copying does take place, the copying must have been of a substantial portion of the work and not of isolated passages or phrases. The term "substantial" is interpreted as relating to both quantity and quality, although the latter is regarded as being of greater importance than the former (Dean 1998: 1-37). A substantial portion in relation to a literary work can therefore refer to a small but extremely important part of it (for example a summary or conclusion). "As long as what is taken has substance in the original work (and is not de minimis) or has sufficient pith to constitute the embodiment of original intellectual activity in a material form, for instance a paragraph in a book or perhaps even a sentence or sequence of sentences, copyright infringement could arise", according to Dean (1998: 1-38). "The criterion is what has been taken from the plaintiff's work and not what portion the infringing material makes up qualitatively of the contentious work." This was the approach followed by our Appellate Court in Payen Components SA Ltd $v$ Bovic CC \& others 1995 (4) SA 441 (A) where the reproduction of individual part numbers from a catalogue of spare parts was regarded as a substantial part from the catalogue.

"As a general rule, if there is only one way to state something, it is not copyrightable", Zelezny (1993: 289) however stresses. "For example, the scientific equation $\mathrm{E}=\mathrm{mc}^{2}$ could not have been copyrighted by Albert Einstein".

The Copyright Act makes special provision for specific circumstances where one may not be liable for infringement when using another's work without his/her permission. These exemptions are allowed because it is considered to be in the public interest that the exclusivity of the copyright owner's rights are limited in certain circumstances (Dean 1998: 1-51). For purposes of the work done by the Centre for Legal Terminology in African Languages the most important of these so-called "statutory defences" are those relating to research (s 12(1)), quotation (s 12(3)) or "by way of illustration ... for teaching" (s 12(4)). Apart from these defences the Act also makes provision for a general exemption in section 13 in terms of which "reproduction of a work shall also be permitted as prescribed by regulation, but in such a manner that the reproduction is not in conflict with a normal exploitation of the work and is not unreasonably prejudicial to the legitimate interests of the owner of the copyright". This means that the regulations issued in terms of the Act must also be consulted to obtain more precise guidelines. When read with the exemptions mentioned in sections 12 and 13, the regulations clearly indicate that use made of another's work must always be reasonable and the source and author's name should be mentioned (in this regard see also Dean 1998: 1-51 to 1-53). 
In the Act reasonableness is equated with fair dealing or fair practice. Although this concept is very vague and subjective and therefore difficult to define, it clearly relates to questions of degree or extent. In the case of quotations, for example, it means that one has to take into consideration such aspects as the number and extent of the quotations (in other words, how much of the text consists of quotation), the use made of the quotations (whether they are used as a basis for comment, criticism or review or to convey mere information), or their proportion to the text in which they are inserted (long extracts with short comments in contrast to short extracts with long comments).

One can argue that the principles set out above are not a stumbling block if, as mentioned earlier, the Centre uses mostly foreign dictionaries for the compilation of its work. However, the copyright of works created in other countries is also protected in South Africa in terms of various international treaties which were incorporated into South African law (by section 37 of the Copyright Act after notice in the Gazette). The oldest and most elaborate treaty in the field of copyright is the one known as the Berne Convention. It had its origin in 1886 in Switzerland and has since been refined and brought up to date by subsequent conventions, the last of which was held in Paris in 1971. The basis of the Berne Convention is that each country that has signed it, undertakes to enforce the copyright of works created or published in any of the other signatory countries as if those works originated in the home country of the signatory (Dean 1998: 88). At present more than 80 countries, including South Africa, have ratified the Berne Convention. In practice this means that works originating within any signatory country are protected in South Africa as if those works were South African.

The above is merely an overview of the most basic principles relating to infringement of copyright. When applied to the compilation of the Centre's dictionary, this overview implies:

(1) Selecting single terms from a source work and using these in a target work does not normally amount to an infringement of copyright. This conclusion can be drawn from the fact that in the case of works comprising common information which is in the public domain, it is not the information that is the subject of protection but the formulation and form of the work (Dean 1998: 1-42). Trittipo (1996: 369 as quoted in Jooste and Alberts 1998: 129) takes the argument further by stating that if the "idea" (in other words the information) and its "expression" (that is the formulation of the idea in words or phrases) are inseparable, copying the expression will not be barred, since protecting the "expression" in such circumstances would confer a monopoly of the "idea" upon the copyright owner. Individual words or terms in general language are the common property of all speakers, since the idea cannot be separated from the way it is expressed in a single word (Jooste and Alberts 1998: 129). In such instances, copyright subsists in the selection of terms rather 
than in the terms per se. The moment a new selection of terms is made, the original work is normally altered to such an extent that the new work cannot be regarded as a copy of the original. As stated in Waylite Diaries CC $v$ First National Bank Ltd 1993 (2) SA 128 133B, "there is a distinction between copying (which negatives originality), and the use by an author of already existing material or of knowledge common to himself and others (which does not)". Where a legal dictionary contains all legal terms in a specific language, the selection of only those terms relating to criminal law or criminal procedural law cannot be regarded as actual copying of the original. However, to be certain that this is not the case, one can add further terms not mentioned in the original work.

(2) If definitions are added to the selected terms, it takes the target work even further from the original source work which was used as basis, but at the same time this conduct leads to new problems. The question then arises of whether a definition that is copied from an existing copyright protected work (South African or otherwise), could, in the light of what has been said above, make the copier liable for infringement of copyright.

Definitions that are structured in such a way that they are comprehensive and precise, are identical to Zelezny's example of the mathematical formula quoted earlier. In the legal field the definitions of most well-known common-law crimes probably fall within this group. For example, defining murder as "the unlawful and intentional causing of the death of another human being" (Snyman 1995: 401 ) is virtually unalterable. One can safely assume that the copying of such a definition does not violate the rights existing in the source.

Unfortunately all definitions are not so easy. Where a definition in a source work is set out clearly and cannot easily be improved on, although it is not the only way in which the wording can be formulated, it can only be copied with impunity if one or more of the defences can be relied upon. The most probable defence would be the one relating to quotations. In such a case however, the proviso mentioned in section 12(3) must be fulfilled, namely "that the quotation shall be compatible with fair practice, that the extent thereof shall not exceed the extent justified by the purpose and that the source shall be mentioned, as well as the name of the author if it appears on the work". Fair practice is not necessarily applicable only to a work as a whole. Where a sentence or phrase is so unique that it is directly linked to the creator thereof, repetition thereof without mentioning the source and indicating that it is a quotation, is regarded as infringement. As it is neither customary nor financially justifiable to quote each source immediately after a specific definition has been given, one should in these cases try to rephrase such definitions as far as possible. 
(3) In the case of statutory crimes, defining the crime does not lead to the copyright issues explained above. In terms of section 12(8)(a) of the Copyright Act, government-created works can be freely quoted because "no copyright shall subsist in official texts of a legislative, administrative or legal nature, or in official translations of such texts".

\subsubsection{Obtaining copyright in the new creation}

The second copyright issue with which the Centre had to deal was whether the new dictionary would enjoy copyright even though it consisted of extracts from various other sources and might infringe the copyright of those works. In this regard section 2(3) of the Act expressly states that "a work shall not be ineligible for copyright by reason only that the making of the work ... involved an infringement of copyright in some other work". As already said a dictionary falls under one of the categories mentioned as protected works in the Act and therefore has the inherent possibility of being protectable. The actual protection depends on whether the other basic requirements have been met. Where this has occurred, there are no further formalities to obtain copyright protection as we do not have a system of registration or recording of copyright in this country (Dean 1998: 1-15).

Briefly stated, the various basic requirements are the following:

\section{(1) Material form}

The Act specifically states that the work must exist in writing or some other material form (s 2(2)). A work cannot enjoy copyright protection before it is fixed in a tangible medium. The creator's particular way of expressing himself/herself is protected, and not his/her raw ideas. The material form in which a work must appear before it enjoys protection, will obviously vary depending on the category of work concerned. It is however not necessary that the material form should express a meaning in language. In the case of a work such as a new dictionary, the "material form" would probably be writing, a tape recording, a computer disk or microchip. It makes no difference where these "material forms" are in themselves meaningless, and can only be read when used in conjunction with a specific machine such as a computer.

\section{(2) Originality}

A work must be original before it can enjoy protection (s 2(1) of the Act). Simply stated, originality means that the author must have created the work - it should not merely be a reproduction of existing material. The work does not need to be unique or inventive, but must be the product of the author's own 
efforts and must not be copied from some other source (Dean 1998: 1-15; also see Kalamazoo Division (Pty) Ltd v Gay 1978 (2) SA 184 (C)). Originality must therefore be viewed as the execution of original skill or labour, and not as original thought or expression of thought (Klep Valves (Pty) Ltd $v$ Saunders. Valve Co Ltd 1987 (2) SA 1 (A) as confirmed in Appleton \& another $v$ Harnischfeger Corporation \& another 1995 (2) SA 247 (A)).

Works may however contain some components which are not original. In such a case the original creative effort is used on material that already exists. "The individual bits of information contained in such works are not original creations of the compilation author, and taken individually they may not even be copyrightable", according to Zelezny (1993: 291). "Yet the compilation as a whole is an original, copyrightable work if the information is selected, arranged, and presented through independent effort and with 'a modicum of creativity', to use the judicial phrase." He then mentions an American court decision of 1991 where a directory containing the names of public relations firms, their addresses and a list of their employees, was declared a copyrightable compilation. In this case the creative effort lay in the soliciting of the listings and determining which firms qualified for inclusion.

In the case of a collection or compilation, individual pieces of information from works that are already in existence, are collected and put together. They are first selected, arranged and then through independent effort and with a degree of creativity presented in a way that gives rise to a new work with its own copyright. The individual contributions may be protected by their own separate copyrights. The copyright of the author of the collection is limited to the collection he has put together (the new compilation). He does not suddenly obtain copyright in someone else's work - in the contributions he has collected.

This aspect of originality was summarised by Lord Atkinson in the English case of MacMillan \& Co v Cooper 1923 LR 51 Ind App 109 (as quoted by Copeling 1978: 15): "To secure copyright for the product it is necessary that labour, skill and capital should be expended sufficiently to impart to the product some quality or character which the raw material did not possess, and which differentiates the product from the raw material." Similar views were expressed in South African court cases (see for example Waylite Diaries CC $v$ First National Bank Ltd 1993 (2) SA 128).

\section{(3)}

\section{Propriety}

For the sake of completeness this requirement is mentioned here, although it does not play a role in the compilation of a dictionary. It is not really a requirement that has to be met but our courts have consistently held that copyright protection will not be given to a work which is improper, defamatory, immoral, blasphemous or obscene. Propriety is therefore not so much a condition for subsistence of copyright but rather a condition for the enforcement of 
copyright (Dean 1998: 1-18; also see Goeie Hoop Uitgewers (Edms) (Bpk) v Central News Agency \& another 1953 (2) SA 843 (W)).

\section{(4)}

\section{Publication or qualified person}

The final requirement that has to be met is that the first publication of the new work should take place within South Africa (s 4 of the Copyright Act) or alternatively, where there is no publication, the author (or in the case of joint authorship, one of the authors) should be a qualified person at the time the work is made (s 3). When one is dealing with an individual, a qualified person means a person who is a South African citizen or is domiciled or resident in the Republic. In the case of a juristic person, a qualified person is a body (institution) incorporated under the laws of the Republic (s 3(1)).

The practical implication of all these requirements is that works are protected before publication while they are still in the process of being created. Those bits and pieces of the Centre's creation that have already been completed (and which fulfil the other requirements of a material form and originality), therefore enjoy copyright protection even though the work as such is not yet ready for publication.

\subsubsection{Who owns the copyright in the Centre's dictionary?}

Where several people are involved in a creation process, it can sometimes be quite problematic to determine who actually created the work. In the case of joint works prepared by two or more authors with the intention that their contributions be merged into inseparable or interdependent parts of a unitary whole, the authors are co-owners of the copyright and share in its profits (Dean 1998: 1-24). Although guidelines exist in this regard and the Act makes special provision for situations where work is done in the course of employment or on consignment, the issue is not always clear. As the provisions of the Act in this regard ( $\mathrm{s} 21$ ) can be altered by written agreement it is therefore recommended that in the case of organisations such as the Centre, this be done in advance in order to avoid disputes and uncertainty over copyright ownership later on.

Although copyright in a new work cannot be registered or approved by a government agency, a copyright notice should be placed on works which are distributed to the public. Such a notice indicates that copyright exists in the work so that a would-be infringer is deterred from copying the work as he/she cannot state as a defence that he/she was not aware of the subsistence of copyright in the work (a statutory defence provided in s 24(2) of the Act against a claim for damages). Where a copyright notice is used, it is recommended that it should appear in a conspicuous position and should contain the following: 
- the word "copyright" or the international symbol ${ }^{\odot}$,

- the year of first publication, and

- the name of the copyright owner.

This form of marking is the one prescribed by the Universal Copyright Convention. Although South Africa is not a member of the convention, this has become the acceptable form of marking in most countries (Dean 1998 : 5-21 fn 88).

\subsubsection{Copyright on the Internet}

The whole issue of copyright is likely to grow even more complicated as electronic manipulation extends. At this stage the Centre has not yet considered making completed definitions available on Internet, so this aspect will not be discussed here. I would however like to refer to a remark by the Internet expert Negroponte (1995: 58): "Copyright law is totally out of date. It is a Gutenberg artefact. Since it is a reactive process, it will probably have to break down completely before it is corrected." This might be an overstatement of the case but it can lead to controversy. On the one hand, some people are of the opinion that the law should not limit the free flow of information on the Internet. On the other hand, most authors and publishers are notably reluctant to make full works available on the Internet as this can affect their prospective income. The future here is still nebulous.

\subsection{Product Liability}

From a lawyer's perspective there is one further aspect which should be kept in mind, namely the basic principle that anyone who, through his conduct, causes harm to another in a situation where the conduct is wrongful and blameworthy, should compensate the injured person for the damage suffered. (As stated in Neethling et al. 1994: 4 these are the general requirements for any delictual claim.) The basic explanations that were given above with regard to criminal conduct and blameworthiness, apply here as well. Wrongfulness in this case is similar to the unlawfulness that was given as an element of a crime, thus relating to conduct that would be regarded as unacceptable by the community because no valid reason exists which could be regarded as excuse for the conduct (Neethling et al. 1994: 31 read with 37 and 67). The development of industries and technology has led to an extension of this basic principle and given rise to what is nowadays called "product liability".

In principle "product liability" means that a manufacturer of a product is liable for harm or damage that might flow from the use of his product if the conduct of the manufacturer during the process of manufacturing can be regarded as wrongful and blameworthy (Neethling et al. 1994: 305). In the case 
of Anglo-American law this liability has developed even further and the requirement of blameworthiness has been diluted by a specific application of the doctrine that facts should speak for themselves. The mere fact that a manufacturer has placed a faulty product on the market then gives rise to certain presumptions, namely that he used an unsuitable production process or that his employees exercised his production process negligently. In this way the basic principle that fault (blameworthiness) should be a requirement for liability is undermined and a disguised no-fault liability arises (Neethling et al. 1994: 307 fn 279). Although such a general "product liability without fault" is not frequently encountered in South Africa, it is propagated by various eminent jurists (see in this regard Neethling et al. $1994: 308$ and the references given there). To date, a consumer who wishes to institute a claim against a manufacturer must prove that the conduct of the manufacturer was blameworthy and wrongful and has as a result caused damage to the consumer.

So far our courts have not yet decided a case of a claim instituted by the user of a dictionary for damage flowing from such use. Taking into regard, however, the unique nature of the dictionary the Centre has in mind, and the prospective target group, it is possible that such a dictionary might give rise to delictual claims based on "product liability". I would therefore like to conclude by referring to a few hypothetical scenarios.

Assume for a moment the dictionary envisaged by the Centre is completed and published. The effect would be that there is an authoritative work available in the domain of criminal law and criminal procedural law giving all the terms encountered in these fields and explaining what each means. As the compilers of the dictionary have acted in their professional capacities, they have tacitly undertaken to provide correct information and in theory are liable for any harm that might arise from use of this product. Alheit (1997: 56) distinguishes three types of liability that might arise from product usage, namely where there is a defect in the product itself, where the product is not defective but is used incorrectly and lastly where the product is available on the market but is not used at all.

In our speculative discussion, the first two possibilities might be present. A definition in the Centre's dictionary might perhaps be incorrect - the product that has been created, is then defective. Assume for a moment that $X$ is a lawyer. He uses this defective definition in order to prepare for a case and due to the incorrect information loses his case. The defect in the product has given rise to the damage, therefore the compilers of the dictionary would be responsible for X's losses. Improbable? But in theory not impossible.

Have a look at the second scenario: in this case $X$ is a female and lives alone in a house. One evening when entering her home, she is attacked by a robber whom she shoots in self-defence. $X$ is accused of murder. She decides to conduct her own defence. She consults the Centre's dictionary in order to determine precisely what is meant by the crime of murder so that she can prepare accordingly. The definition of murder reads: "the unlawful and intentional 
causing of another person's death". $X$ regards her conduct as unlawful because it is contrary to the legal norms applicable in this country. She also regards her conduct as being intentional because when she fired the shot she intended to kill the robber. She therefore pleads guilty to the charge and presents no evidence on her own behalf. She is found guilty and sentenced. Incorrect use of the correct information in the dictionary has in this case been the cause of her downfall. (In practice this cannot happen in the case of a murder charge because even where an accused pleads guilty, the state still has to prove the basic elements of the crime. The example was merely chosen because of the brevity of this specific definition.)

\section{Conclusion}

The examples given above might be preposterous and over-simplified, but with the ever increasing use made of "do-it-yourself law", similar scenes might easily arise. This is not the appropriate time or place to discuss the relevant legal principles in more detail as these comprise a whole new field of study. Hopefully the dictionary we are compiling at present, will weather all storms.

\section{References}

Alberts, M. 1997. Legal Terminology in African Languages. Lexikos 7: 179-191.

Alheit, Karin. 1997. Issues of Civil Liability from the Use of Expert Systems. Unpublished LL.D. thesis. Pretoria: University of South Africa.

Beets, A. and J. W. Muller (Eds.). 1900. Woordenboek der Nederlandsche Taal Viffde deel. 's Gravenhage: Martinus Nijhoff.

Claassen, RD. 1997². Dictionary of Legal Words and Phrases. Durban: Butterworths.

Coertze, L.I. and V.G. Hiemstra. 1947. English-Afrikaans Legal Dictionary. Cape Town: Juta.

Constitution of the Republic of South Africa 108 of 1996 (as amended). Pretoria: Govemment Printers.

Copeling, A.J.C. 1978. Copyright and the Act of 1978. Durban: Butterworths.

The Copyright Act 98 of 1978 (as amended). Pretoria: Govemment Printers.

The Criminal Procedure Act 51 of 1977 (as amended). Pretoria: Government Printers.

David, René and John E.C. Brierly. $1978^{2}$. Major Legal Systems in the World Today. London: Stevens \& Sons.

Dean, O.H. 1998. Handbook of South African Copyright Law (Loose leaf). Cape Town: Juta.

Gamer, Bryan A. 1995'. A Dictionany of Modern Legal Usage. New York: Oxford University Press.

Handler, Jack G. 1994. Ballentine's Law Dictionary: Legal Assistant Edition. New York: Delmar.

Hanks, Patrick (Ed.). $1989^{2}$. Collins Dictionary of the English Usage. London: Collins.

Hiemstra, V.G. and H.L. Gonin. 1992 ${ }^{3}$. Drietalige Regswoordeboek/Trilingual Legal Dictionary. Cape Town: Juta.

Hosten, W.J., A.B. Edwards, Carmen Nathan and Francis Bosman. 1977. Introduction to South African Law and Legal Theory. Durban: Butterworths. 
Jansen M. 1993. Enkele regsprobleme rondom gesinsgeweld. Social WorkMaatskaplike Werk 29(3): 201-212.

Jooste, Michiel and Mariëtta Alberts. 1998. Lexicography, Terminography and Copyright. Lexikos 8: $122-139$.

Marais, C.A. 1980. Marais se Juridiese Woordeboek/Marais' Juridical Dictionary. Verwoerdburg: Hennop-uitgewers.

Milne, Alexander, Clifford Cooper and Brian D. Burne. 1951'. Bell's South African Legal Dictionary. Durban: Butterworths.

Neethling, J., J.M. Potgieter and P.J. Visser. 1994. Law of Delict. Durban: Butterworths.

Negroponte, Nicholas. 1995. Being Digital. London: Hodder \& Stoughton.

Smuts, J. en I.J. Smuts. 1992. Woordeboek van Regs- en Handelsterme. Kaapstad: Nasou.

Snyman, C. R. 1995'. Criminal Law. Durban: Butterworths.

Trittipo, M. 1996. A Primer on Translations and Copyright. Global Vision. Proceedings of the 37th Annual Conference of the American Translators Association, Colorado Springs, October 3, 1996: 367371.

Walker, David M. 1980. The Oxford Companion to Law. Oxford: Clarendon Press.

Zelezny, John D. 1993. Communications Law: Liberties, Restraints and the Modern Media. Belmont: Wadsworth. 


\title{
Functionele aspecten van de gecomputeriseerde lexicografie
}

Joost Kist, Lid van het dagelijks bestuur van de Stichting Instituut voor Nederlandse Lexicologie te Leiden, Nederland

\begin{abstract}
Functional Aspects of Computerised Lexicography. The computerisation of lexicography has meant that traditional dictionaries are now supported, supplemented and - in some places - already supplanted by new electronic off- and online information carriers. The Woordenboek der Nederlandsche Taal (WNT) which was "completed" in 1998 and its electronic successors form a case study of these developments. In addition to a short description of the WNT project, this article also focuses on the functional aspects of computerised lexicography. Some of the more general aspects of information and knowledge technology are stressed, including the role of the user who needs to carry out his/her searches through the language banks of the future with the least possible effort.
\end{abstract}

Keywords: COMPUTERISED LEXICOGRAPHY, ELECTRONIC DICTTONARY, ELECTRONIC PUBLISHING, INFORMATION AND COMMUNICATION TECHNOLOGY, ON-LINE ACCESS VIA INTERNET, USER INTERFACE

Samenvatting: Computerisering van de lexicografie heeft er toe geleid dat het traditionele woordenboek thans wordt ondersteund, gesupplementeerd en - op sommige plaatsen - reeds verdrongen door nieuwe electronische off- en on-line informatiedragers. Het in 1998 "voltooide" Woordenboek der Nederlandsche Taal (WNT) en zijn electronische opvolgers vormen een case study met betrekking tot deze ontwikkeling. In dit artikel wordt - naast een korte beschrijving van het WNT project - aandacht besteed aan de functionele aspecten van de gecomputeriseerde lexicografie waarbij de nadruk ligt op enige meer algemene aspecten van de informatie- en kennistechnologie en de positie van de gebruiker die zijn/haar zoektochten door de taalbanken van de toekomst met zo min mogelijk moeite moet kunnen volvoeren.

Trefwoorden: COMPUTERONDERSTEUNDE LEXICOGRAFIE, ELECTRONISCH WOORDENBOEK, ELECTRONISCH UITGEVEN, INFORMATIE EN COMMUNICATIETECHNOLOGIE, ON-LINE TOEGANG TOT HET INTERNET, GEBRUIKERSINTERFACE

\section{Inleiding}

In dit artikel willen wij tegen de achtergrond van het gereedkomen van het Woordenboek der Nederlandsche Taal in 1998 en de ontwikkeling van nieuwe lexicografische producten en diensten van het Instituut voor Nederlandse Lexicologie (INL) een aantal functionele en meer algemene aspecten van het vervaar- 
digen en gebruiken van - wat wij noemen - "informerende systemen" aan de orde stellen (Kist 1996).

Telkens als er in de geschiedenis van de mensheid een nieuw informatiemedium wordt uitgevonden, zien wij dat de snelheid van informatieverstrekking wordt opgevoerd, terwijl gelijktijdig de hoeveelheid informatie gaat toenemen.

De eerste stap in dat technologisch proces was de uitvinding van het pictografisch schrift door de Sumeriërs en Egyptenaren, ruim 3000 jaar voor Christus. Vervolgens werd dit "informerend systeem" via de uitvinding van syllabische en fonetische tekens versimpeld tot bruikbare alfabetten die voornamelijk toegepast werden bij de vervaardiging van "unicaten" van teksten zoals woordenlijsten, boekhouding, wetgeving en godsdienstige voorschriften. Stempel- en rolzegels boden overigens direct mogelijkheden tot duplicering "in druk" van persoonlijke gegevens. Wij kunnen dus in het verband van dit artikel al direct constateren dat woordenlijsten tot de allereerste cultuurproducten behoorden (Schaer 1996). De gelijktijdige uitvinding en/of toepassing van de losse loden letter, van de drukinkt en van de drukpers leidde omstreeks 1450 tot voorheen ongekende dupliceringsmogelijkheden van tekst en daardoor tot een universele geletterdheid van de mensheid (Kist 1988). Sinds de introductie en de implementatie van het informerend systeem van Gutenberg zijn er een viertal trends in de verspreiding van informatie waar te nemen:

- Een acceleratie van de productie van tekst in kwantitatieve en in kwalitatieve zin.

- Een segmentatie van de inhoud (gebruik van tekst voor meerdere doeleinden).

- Informatieverspreiding onder een groot publiek.

- En - gedurende de afgelopen decennia - een snel toenemende digitalisering van informatie die weer leidde tot een efficiente redactionele verwerking en tot goedkope opslag van grote hoeveelheden tekst, beeld en geluid.

Deze vierde trend versterkte de effecten van de eerste drie trends. Bij de invoering van de computer is bovendien de "connectiviteit" (de mogelijkheid om via een netwerk ieder stukje informatie van het ene naar het andere punt te transporteren) sterk toegenomen.

Inhoudelijke informatie wordt hierbij als het ware losgeweekt uit het informerend systeem (dus de gekozen informatiedrager) en gaat zich zelfstandig bewegen in de electronische omgeving. De klassieke informatieketen (bijv. auteur - uitgever - drukker — binder - boekhandel - bibliotheek - lezer) wordt nu verbroken en er gaan nieuwe diensten, producten en merken ontstaan die hun eigen, electronische route kunnen kiezen, waarbij ze de verschillende stations in de traditionele keten kunner omzeilen. Er ontstaan zo nieuwe 
informatiebronnen en informatiecombinaties, wat weer tot een grote verscheidenheid aan informerende systemen zal leiden. Een recent voorbeeld van deze ontwikkeling is het electronisch tijdschrift dat in een van zijn vele nieuwe verschijningsvormen rechtstreeks, zonder kwaliteitscontrole van een referee of tussenkomst van een uitgever, van auteur naar lezer wordt getransporteerd (Kist 1996).

Het is duidelijk dat de technologie van de gecomputeriseerde verwerking van tekst en het rechtstreeks in het verlengde daarvan liggende electronisch uitgeven van zeer grote betekenis is geworden voor de samenstelling en het gebruik van woordenboeken. In vorige afleveringen van Lexikos is hierover met betrekking tot het WNT al deskundig en uitvoerig gerapporteerd (Kruyt 1995 en Kruyt en Dutilh 1997), wat ons ontslaat van de plicht hierop opnieuw in te gaan bij het in kort bestek releveren van de ontstaansgeschiedenis van het WNT.

\section{Het WNT en het Instituut voor Nederlandse Lexicologie}

Het WNT is het grootste woordenboek ter wereld. Het kostte vijf generaties redacteuren bijkans honderdvijftig jaar om dit gigantische werk te voltooien. Het telt 40 banden, 45805 bladzijden en het beschrijft tussen de 350000 en 400000 woorden uit de periode 1500 tot ongeveer 1921. Er zijn ongeveer 1,6 miljoen citaten uit bijna 10000 bronnen verwerkt. Anderhalve eeuw is een lange tijd om aan een boek te werken en er is in die periode natuurlijk veel gebeurd. Uitgevers dreigden af te haken en er werd veel interne strijd geleverd. Nederlandse en Vlaamse overheden die het kostbare project financierden zijn enige malen van plan geweest het bijltje er bij neer te gooien. De beslissing, genomen in 1976, om geen bronnenmateriaal van na 1921 meer te verwerken gaf uiteindelijk de doorslag; zonder dit besluit was het WNT nooit meer afgekomen. Wel werd hierdoor het karakter van het WNT definitief bepaald: het is uitgegroeid tot een historisch-wetenschappelijk woordenboek dat op basis van miljoenen citaten de taal van 1500 tot 1921 analyseert. Ondanks bepaalde tekortkomingen is het WNT een onmisbaar wetenschappelijk instrument waarop andere Nederlandse woordenboeken zoals Van Dale, Koenen en Kramers zwaar steunen. Voor ons betoog is echter het meest interessant dat de bruikbaarheid van het WNT exponentieel is toegenomen door de vervaardiging van een cd-rom door AND Electronic Publishing in samenwerking met het INL. Deze cd-rom die te zijner tijd ook op het Internet geraadpleegd kan worden biedt de mogelijkheid, alle zoekopties electronisch bliksemsnel te exploreren en toont aldus de voordelen en toegevoegde waarde van het electronisch uitgeven onweerlegbaar aan.

Het nu voltooide WNT is niet het enige, maar vooralsnog wel het grootste project van de in 1967 opgerichte stichting Instituut voor Nederlandse Lexicolo- 
gie (INL). De bijna vijftig Nederlandse en Vlaamse medewerkers leggen de woordenschat van heden en verleden vast in woordenboeken en woordenboekachtige producten, zoals electronische bestanden en cd-roms. Het INL mag men beschouwen als de schatbewaarder van de Nederlandse taal. Het WNT is nu voltooid maar een woordenboek is nooit af. Voor de medewerkers van het INL begint nu een nieuwe periode, met nieuwe en uitdagende projecten.

In 1999 zal aandacht besteed worden aan de voltooiing van het Vroegmiddelnederlands Woordenboek. Voorts zal de Taalbank van het INL, die miljoenen woorden aan (voornamelijk modern-)Nederlandse teksten bevat, geleidelijk worden uitgebouwd tot een Geintegreerde Taalbank van het Nederlands van de 8 ste tot de 21ste eeuw. In 1999 vangen eveneens de werkzaamheden aan voor een te produceren Oudnederlands Woordenboek, dat het alleroudste Nederlands uit de periode 750 tot 1150 zal beschrijven. Een ander nieuw en omvangrijk project betreft een Woordenboek van het Eigentijds Nederlands. Voorts blijft het INL verantwoordelijk voor het actualiseren van de Woordenlijst Nederlandse Taal, het bekende Groene Boekje. Tenslotte zal het voltooide WNT op enkele onderdelen nog kwantitatief en kwalitatief worden bijgewerkt, eerst in drie à vier delen "Aanvullingen" die op het supplementmateriaal zijn gebaseerd, vervolgens in een apart project "voortgezet WNT".

Op basis van de door het INL gevolgde strategie is het in dit stadium mogelijk een aantal potentiële producten en diensten te identificeren en doelgroepen te selecteren die voor verdere ontwikkeling en toepassing in aanmerking kunnen komen. Wij onderscheiden toepassingen ten behoeve van een groot aantal productcategorieën:

- In de categorie woordenboeken is een grote diversiteit van mogelijkheden potentieel aanwezig, zowel qua inhoud en doelgroep als in de technische vorm (folio, cd-rom, on-line enz.), hulpmiddelen op het gebied van semi-automatische vertaalsystemen enz.

- Uitgaven gebaseerd op uitwerking van specifiek taalkundig materiaal voor wetenschappelijke doeleinden (bepaalde grammaticalia, stilistische grammatica's respectievelijk woordenboeken en -lijsten van bepaalde taalkringen, lijsten per tijdsperiode, regio). Overigens kunnen in deze categorie ook producten voor meer algemene marktsegmenten worden geïdentificeerd, bijvoorbeeld puzzelwoordenboeken.

Uitgaven gebaseerd op taalgebruik (taalgebruik van bepaalde auteurs of perioden, verzamelingen, uitdrukkingen, spreekwoorden, zegswijzen); Producten gericht op gebruik als spellingcheckers (voorzetselverbindingen, synoniemen of taxonomische informatie, ontledingen en moeilijke taalkundige woord- en spellingsvormen e.d.). Hiervoor zijn zowel algemene als specifieke doelgroepen of marktsegmenten aan te geven.

- Tevens zou een database ook specifieke, gerichte custom-made informatieproducten voor specifieke afnemers c.q. afnemersgroepen kunnen 
opleveren terwijl de electronische ontsluiting en karakteristiek tevens output in verschillende vorm mogelijk zouden maken (on-line, cd-rom, Internet-downloading enz.).

\subsection{Succesfactoren van de INL/WNT combinatie}

Als succesfactoren die bij alle genoemde innovaties geleid hebben tot verbetering van de inhoud en van het proces van intellectuele creatie kunnen wij - het bovenstaande samenvattend - de volgende punten noemen:

- Toepassing van breed aanwezige interne redactionele expertise op diverse terreinen;

- Toegang tot betrouwbare informatiebronnen en documentatie informatiebronnen;

- Steun van betrokken ministers en overheden in Nederland en België;

- Waar mogelijk inschakeling van electronica (die gelukkig in de loop van de tijd steeds goedkoper werd hetgeen budgettair een meevaller was) en databanktechnologieën als hypertext en digital object identifiers; kennis van de informatie- en communicatietechnologie;

- Goede projectorganisatie en -leiding;

- Gestroomlijnde productie;

- Nieuwe producten en spin-off producten ("herverpakking" en verrijking van informatie) kunnen vrij gemakkelijk worden gegenereerd;

- Effectieve ontsluiting van informatie en herbenutten van meerwaarde van het bestand;

- Gedegen kennis van de gebruikerscategorieën;

- Internationale uitwisseling van expertise; en

- Goed management.

Mogelijke faalfactoren (die zich niet hebben voorgedaan) waren:

- Wegvallen van politieke steun voor de financiering;

- Afhankelijkheid van externe opslag en distributie; en

- Het niet kunnen aantrekken of behouden van deskundige medewerkers.

\section{Functionele aspecten van de woordenboekenproductie}

\subsection{Aan welke functies heeft een gebruiker behoefte?}

Als wij nu de voorgaande case study tot een meer algemene beschouwing over toekomst van de vervaardiging van woordenboeken trachten te verbreden dan is het noodzakelijk dat wij ons eerst verdiepen in de vraag, aan welke functies 
de gebruiker van een informerend systeem en in het bijzonder van een woordenboek behoefte kan hebben. Wij komen dan tot de volgende opsomming:

- De gebruiker heeft allereerst natuurlijk behoefte aan een bepaalde inhoudelijke informatie (kwaliteitsselectie).

- Vervolgens wenst hij of zij een bepaalde diepgang of structuur (niveauselectie).

- Dan is er behoefte aan een bepaalde hoeveelheid (kwantiteit, niet te weinig maar zeker ook niet te veel).

- In het bijzonder bij de inzet van nieuwe media komt een behoefte aan een bepaalde snelheid naar voren (de levertijd die vroeger in uren of dagen werd gemeten mag nu niet langer dan seconden of nog minder duren).

- Ook zijn er specifieke wensen omtrent een bepaalde technologische prestatie of verpakking; men wil kunnen "browsen", "skimmen" en "scannen", men wil in "portals" rondneuzen of gegarandeerd veilige netwerken inschakelen. Veelal wil men de informatie toch weer op papier binnen bereik hebben (output).

- Belangrijk is ook het gebruiksgemak passend bij de gebruiksomgeving (comfort).

- Tenslotte is er natuurlijk de prijs (prijselasticiteit).

Deze opsomming is niet limitatief, maar de wensen van een gebruiker zijn altijd terug te brengen tot de klassieke "ijzeren driehoek": Prijs, Kwaliteit, Levertijd. De woordenboekenproducent zal ook in de 21ste eeuw met deze elementaire wensen rekening dienen te houden. Wij dienen ons dus af te vragen welke doelen wij bij de inzet van nieuwe media voor ogen moeten hebben.

\subsection{Doelstellingen}

Welke doelstelling willen wij door middel van digitalisering en computerisering bereiken? Wij doen het beste, deze doelstelling vanuit vier gezichtspunten te bezien:

- Met betrekking tot het vervaardigings- en vermenigvuldigingstraject;

- Met betrekking tot het informatieproces;

- Met betrekking tot de toevoeging van meerwaarde aan de inhoud; en

- Met betrekking tot verbetering van het rendement.

Verbetering van de productiviteit en de efficiency in het traditionele grafische vervaardigingsproces kan bereikt worden door digitalisering van de tekstver- 
werking, door diverse innovaties in het vermenigvuldigings- en verspreidingstraject en waar nodig en mogelijk door introductie van nieuwe media, van cdrom tot Internet. Deze productiviteits- en efficiencyverbetering zet nog steeds door en wij zagen dat allereerst de traditionele zetter in het grafisch bedrijf werd vervangen door tekstverwerking intern en in landen met lage lonen.

$\mathrm{Na}$ het geleidelijk uit het zicht verdwijnen van de klassieke drukkerij gaat men zich ook afvragen, welke rol de traditionele uitgever in de toekomst moet spelen, nu de regie van het redactionele apparaat geheel binnen de muren van een lexicografisch instituut kan worden uitgeoefend. Ook hier zullen drastische veranderingen in de informatieketen gaan optreden en mogelijk wisselende coalities in de plaats komen van de huidige lineaire verhoudingen.

Bij de verbetering van het informatieproces moeten wij vooral denken aan innovaties op het terrein van het redactionele werk met behulp van hardware en software. Controle op de uniformiteit van de teksten (wij gaven al eerder het voorbeeld van de cd-rom van het $W N T$, die wonderlijke inconsistenties en doublures opspoorde), het aanbrengen van hiërarchische relaties en de opbouw van relationele databases zijn hier enkele trefwoorden in een heel scala van te verwachten verbeteringen.

Heel belangrijk is ook de mogelijkheid van het toevoegen van meerwaarde aan en de tussentijdse verbetering van informatieve producten en diensten. Wij zien een voortdurende verbetering van gebruiksvriendelijkheid, betere navigatiemogelijkheden, uitgekiende helpfuncties, gelaagde presentaties en het aanbrengen van hyperlinks. Bestanden kunnen continu verrijkt worden en meer gegevens per trefwoord kunnen op de zoekplaats worden aangebracht. Hier staan wij nog maar aan het begin van vele nieuwe ontwikkelingen die lang niet altijd hun oorsprong vinden in de techniek maar vooral ook in de menselijke inventiviteit, de "intellectuele technologie".

De mogelijkheden tot verbetering van het financiële rendement zijn onder meer te vinden bij het uitgeven via het Internet. $\mathrm{Bij}$ een groeiend aantal gebruikers nemen de kosten van het (re)produceren - dit in tegenstelling tot het traditionele drukproces - nauwelijks toe. Bits zijn gemakkelijk te kopiëren en de communicatiekosten over het Internet zijn te verwaarlozen in vergelijking met de vaste kosten voor het creëren van informatiesystemen, de indexen en de inhoud. De inkomsten lopen derhalve snel op bij het toenemen van het aantal betalende (of gesubsidieerde) gebruikers terwijl de kosten nagenoeg constant blijven. Op het Internet bieden de zogenaamde portal sites informatie(-indexering), communicatie en andere functies aan. Het gemak voor de gebruiker bestaat $0 . \mathrm{m}$. hierin dat hij minder hoeft te klikken om zijn informatiebehoefte te bevredigen. 


\subsection{Conclusies met betrekking tot nieuwe functionaliteiten}

Hoewel digitale tekstverwerkingsprocessen en electronic database publishing al sinds de jaren 70 bestaan, beginnen zij nu - na vele mislukkingen en kostbare vergissingen - door te breken, in het bijzonder voor documentaire netwerken en informerende systemen als woordenboeken en andere grote tekstcorpora. Wij zien een ontwikkeling van woordenboek naar woordenbank maar we zien terzelfdertijd dat verschillende media verschillende behoeften zullen bevredigen: "different media favour different content" (Kist 1996). Er is nog geen universele ideale informatiedrager zoals eens klei, papyrus of papier, geschikt voor alle doeleinden. Er zullen diverse dragers naast elkaar blijven bestaan, puttend uit een digitale woordenbank.

Het papier als medium voor opslag, presentatie en annotatie is overigens nog lang niet op alle fronten verslagen en het foliotijdperk loopt kennelijk nog niet ten einde. De informatiegebruiker wil tekst (bijv. van een website) veelal ook nog op papier zien of vasthouden, alleen al omdat veel electronische producten thans in wezen nog versies zijn van informatie die evengoed op papier had kunnen worden vastgelegd zonder de tussenkomst van computerprogramma's. Printers zijn een belangrijk onderdeel van elke computerconfiguratie. Ook de uitgevers constateren dat "puur" electronisch uitgeven nog lang niet universeel is doorgebroken, zoals zij nog kortgeleden triomfantelijk voorspelden. Het publiceren van documentaire informerende systemen - of dat nu commercieel of in universitair verband plaatsvindt - zal in het begin van de volgende eeuw in vele vormen en op vele manieren geschieden. Het gaat er vooral om, de eigen, "proprietary" informatiebestanden zo goed mogelijk te beheren, te bewaken, te verrijken en daarbij uit de vele mogelijkheden de beste verspreidings- en exploitatiemogelijkheden te kiezen: het kapitaal zit in de kwaliteit van de eigen redacteuren en medewerkers en in de breedte en diepte van de eigen taalbank.

Wij weten nog niet hoe de nieuwe informerende systemen van de volgende eeuw genoemd zullen worden als begrippen als "woordenboek" en "taalbank" verouderd zullen zijn maar ze zullen waarschijnlijk de volgende kenmerken vertonen:

- de informatie zal gesegmenteerd zijn in precies afgewogen en op de gebruiker toegesneden porties;

- de informatie zal gefiltreerd zijn (intelligent geordend en ontdaan van onnutte, ongecontroleerde gegevens en doublures);

- de informatie zal aangepast zijn bij het specifieke medium (mediumspecifiek);

- de informatie zal geïntegreerd zijn (tekst, bewegend beeld en zo nodig geluid, dus multimediaal); 
- de informatie zal toegespitst zijn op het leveren van oplossingen verrijkt met bruikbaarheidscriteria; en

- de informatie zal interactie mogelijk maken (dialoog tussen bron en gebruiker).

In het nabije verleden, toen de databanken nog voornamelijk op naslag of research waren gericht, lag de nadruk op documentatie en volledigheid. De beschikbare apparatuur werd ingezet om alle informatie op een bepaald gebied te verwerken. De sterk toegenomen verwerkingscapaciteit en snelheid van de apparatuur hebben in vele gevallen geleid tot het beschikbaar komen van veel te veel gegevens, relevant, niet relevant, overbodig, doublerend, verouderd en hinderlijk. Parkinson zou een nieuwe wet hebben kunnen formuleren die luidt: "Information expands to fill up the capacity of the system." Het is duidelijk dat een van de belangrijkste toekomstige functies van de informatieverschaffer zal zijn het functioneren als sluiswachter (om een typisch Nederlandse metafoor te hanteren). Informatieverschaffers moeten betrouwbare, toegespitste informatie leveren, gericht op de specifieke behoefte van de individuele gebruiker, op mensen met een individueel wensenpatroon, niet te veel en niet te weinig. Nieuwe media en nieuwe diensten vereisen een nieuwe presentatiewijze en een aanpassing van de inhoud.

Bell (1973) noemde de informatievoorziening in de postindustriële maatschappij een "game between persons". Inderdaad begint en eindigt de kennisketen bij de mens. De intellectuele mens, de homo faber, de homo economicus of de homo ludens. Er is een nieuw soort van inspanning nodig om de intellectuele prestatie, de informatie en de kennis via de nieuwe informatieketens op de juiste wijze bij de intellectuele ontvanger, de lezer, de gebruiker te brengen. Daarvoor zijn nieuwe "intellectual tools" nodig. Wij hebben het gevoel dat de lexicografen en de lexicografische technologen (Kruyt 1995) en redacties van de nieuwe woordenboeken bij uitstek degenen zullen zijn die deze functie in de volgende eeuw zullen gaan vervullen.

\section{Literatuur}

Barquin, R e.a. 1979. Building, Using and Managing the Datawarehouse. New York: Prentice Hall. Bell, D. 1973. The Coming of the Post-industria Society. New York: Basic Books.

Boer, M. de. 1997. Organisationele innovatie door traditionele uitgeverijen: De transformatie van mono naar mixed media. IEI, Informatie- en Informatiebeleid 15(2): 92-100.

Kist, J. 1988. Electronic Publishing: Looking for a Blueprint. New York: Routledge.

Kist, J. 1995. Uitgevers tussen papier en electronica. IEI, Informatie en Informatiebeleid 13(1): 13-20.

Kist, J. 1996. Bibliodynamica: Slaag-en faalkansen bij innovatie van informerende systemen, in het bijzonder in het uitgeversbedrijf. Amsterdam: Cramwinckel.

Kruyt, J.G. 1995. Technologies in Computerized Lexicography. Lexikos 5: 117-137. 
Kruyt, J.G. en M.W.F. Dutilh. 1997. A 38 Million Words Dutch Text Corpus and its Users. Lexikos 7: 229-244.

Schaer, R (Red.). 1996. Tous les savoirs du monde, encyclopédies et bibliothèques, de Sumer aux XXI siècle. Parijs: Bibliothèque Nationale Française.

Verkuyl, Henk. 1998-1999. Een fusie tussen Van Dale en de Winkler Prins? Trefwoord 13: 135-151. 


\title{
Translating Culture in Bilingual Dictionaries*
}

\author{
Ernst Kotzé, School of Languages, University of Port Elizabeth, Port Eliza- \\ beth, Republic of South Africa
}

\begin{abstract}
In addition to the act of translation, transculturalisation and strategies of textuality come into play as interacting factors in the compilation of interlingual dictionaries. In this article, some conclusions resulting from a comparative survey of some South African dictionaries are drawn, specifically with regard to bi- and trilingual dictionaries in which Afrikaans, English, Japanese, Xhosa and Zulu combine as macrostructural components. After relating the act of translating in the various dictionaries to equivalence-based and descriptive theories of translation, the phenomenon of cultural transposition between lemma and translation equivalent is investigated. Starting with a brief characterisation of the dictionaries, the different perspectives and cultural biases vis-a-vis the "other" culture as reflected in the selection of lemmas and editorial examples are highlighted. In situating each instance of lexicographical contact, certain text linguistic principles are considered and applied to dictionary articles as units of discourse.
\end{abstract}

Keywords: ACCEPTABILITY, AFRIKAANS, ASSOCIATIVE MEANINGS, CULTURAL STUDIES, ENGLISH, INFORMATIVITY, INTENTIONALITY, INTERLINGUAL DICTIONARIES, JAPANESE, LABELLING, LEXICOGRAPHY, MACROSTRUCTURAL SELECTION, OFFENSIVE ITEMS, OSTENSIVE ADDRESSING, PRINCIPLES OF TEXTUALITY, TEXT LINGUTSTICS, TRANSLATION, XHOSA, ZULU

Opsomming: Vertaling van kultuur in tweetalige woordeboeke. Benewens die handeling van vertaling, tree transkulturalisasie en strategieë van tekstualiteit as interaktiewe faktore op by die saamstel van intertalige woordeboeke. In hierdie artikel word enkele gevolgtrekkings gemaak as uitvloeisel van 'n oorsig oor sommige Suid-Afrikaanse woordeboeke, meer bepaald twee- en drietalige woordeboeke waarin Afrikaans, Engels, Japannees, Xhosa en Zulu as makrostrukturele komponente gekombineer word. Nadat die handeling van vertaling in die betrokke woordeboeke met ekwivalensie-gebaseerde en deskriptiewe teorieë van vertaling in verband gebring word, word die verskynsel van kulturele oordrag tussen lemma en vertaalekwivalent ondersoek. Eers word ' $n$ kort karakterisening van die betrokke woordeboeke gegee, en dan word die onderskeie perspektiewe en kulturele vooroordele ten opsigte van die "ander" kultuur soos weerspieël in die keuse van lemmas en redaksionele voorbeeldsinne belig. By die situering van elke geval van leksikografiese kontak word bepaalde tekslinguistiese beginsels oorweeg en toegepas op woordeboekartikels as eenhede van diskoers.

* This paper was presented at the Second International Conference of the African Association for Lexicography, held at the University of Natal, Durban, 14-16 July 1997.

Lexikos 9 (AFRILEX-reeks/series 9: 1999): 89-107 
Sleutelwoorde: AANSTOOTLIKE ITEMS, AANVAARBAARHEID, AFRIKAANS, ASSOSIATIEWE BETEKENISSE, BEGINSELS VAN TEKSTUALITEIT, ENGELS, ETIKETTERING, INFORMATIWITEIT, INTENSIONALITEIT, INTERTALIGE WOORDEBOEKE, JAPANNEES, KULTURELE STUDIES, LEKSIKOGRAFIE, MAKROSTRUKTURELE SELEKSIE, OSTENSIEWE ADRESSERING, TEKSLINGUSTIEK, VERTALING, XHOSA, ZULU

\section{Introduction}

The focal point of this article is the interface between translation theory, metalexicography and cultural studies. There is, however, also a particular linguistic perspective which lies at the basis of such a topic. Because both translation and lexicography are applied linguistic fields, it is only natural that an empirical base is important. For this reason, the view of language will be text-based, sociolinguistic and pragmatic.

Dictionaries constitute a very specific text genre. This is borne out by the format in which they are produced, which entails, inter alia, that compilers follow a strict microstructural blueprint for the layout of each article. On this score at least, then, the field of text linguistics (as an extension of discourse studies) provides an obvious framework for the assessment of the work done by lexicographers. It can be indicated that De Beaugrande and Dressler's (1982) seven principles of textuality (as investigated and applied by many other authors, such as Carstens and Hubbard 1993, Van Dijk 1985, Renkema 1993, Petöfi 1990, Du Plessis and Bosch 1999, etc.) are all, to a greater or lesser degree, applicable to dictionary articles by and large. It would be possible to devote an article to a discussion of the ways in which especially the microstructure of these dictionaries complies (or does not comply) with the principles of cohesion, coherence, intentionality, acceptability, contextuality, informativity and intertextuality. Within the framework of the present topic, it would be particularly useful to select two of these principles, viz. informativity and acceptability, and investigate the degree to which they are being applied, as cornerstones of effective discourse, in the dictionaries under discussion. I shall return to these principles in paragraph 3 . $^{\prime}$

As far as translation theory is concerned, the realities of semantic and cultural differences, especially between languages and cultures which are not closely related, make it well-nigh impossible to accept the premise of lexicalsemantic equivalence as a primary criterion. The traditional distinction between a prescriptive and a descriptive approach is made by Toury (1980) who points out that the prescriptive approach attempts to answer the question whether there is semantic equivalence between the source text and the target text, whereas the descriptive approach, on the other hand, rather investigates the nature of the equivalence if text $\mathrm{A}$ is regarded as a translation of text $\mathrm{B}$. In terms of the prescriptive approach, the point of departure for equivalence is (a) the source text and (b) the translation process, or put differently, the "translatability" of a text and the translation possibilities at the disposal of the transla- 
tor. This presupposes an abstract or ideal relation between the source text and the target text. Translating equivalence is thus a prerequisite for establishing any relation between the two texts, which in a particular instance is either achieved or not. Descriptive translation theory, on the other hand, is aimed at the target text and the relation between the two texts is analysed and described as an empirical phenomenon. It should be clear that the prescriptive approach must lead to a speculative theory, because it accepts (and expects) both semantic and grammatical equivalence. The nature of the equivalence relation between source text and target text is not considered. It is of course so that in genealogically related languages a fairly consistent correlation between semantic and grammatical equivalence is normally displayed. (A transitive verb in French or German is usually translated by means of a more or less semantically equivalent transitive verb of the same subcategory in, say, English.) In the case of genealogically unrelated, or typologically divergent languages, however, this correlation is often conspicuously absent and it is therefore important to explain systematic differences between the two languages on the grammatical level. For this reason the descriptive approach is the proper point of departure to investigate equivalence relations and to raise, in the case of a translating dictionary, the problem of equivalence as a function of lemmatic addressing, whether it be grammatical, semantic or pragmatic.

For the purpose of this article, therefore, the phenomenon of translation in bilingual dictionaries is investigated only in so far as it pertains to strategies of bringing about equivalence of whatever kind between lemmas denoting "cultural" items in the source language and the corresponding translating entry in the target language, or translating equivalent, as it is commonly known. What makes this investigation extremely interesting is that with the exception of the English/Afrikaans dictionary, the languages dealt with in the publications discussed in this article represent both grammatically and culturally unrelated pairs.

A final point to be made regarding the theme of this discussion is the definition of what the term culture means in the context of translation in dictionaries. According to Gabriele Becher (1995: 294), culture is understood as "the sum total of a social community's behaviour patterns, including the 'rules' of behaviour and its (material and immaterial) 'results"'. She states further: "As we have already indicated that language is considered to be a cultural product, at the same time, language may be considered part of the manifestation of culture-specific behaviour." A complicating factor is that from the viewpoint of lexicography, particular linguistic forms (of whatever structural complexity) can be regarded as having the semantic feature [+ cultural], whereas others are culturally "neutral". By way of synopsis, then, it would seem that language as a phenomenon forms part of the cultural stock of a community (which implies that matters linguistic are "cultural" by definition), but that the lexis of a language in particular, in its signifying function, also contains elements which denote concepts (other than linguistic ones) representing manifestations of culture-specific 
behaviour. It would therefore be possible to simply discuss grammatical features of the relevant languages as "cultural" phenomena. However, I would then be ignoring a distinction that I suspect is tacitly assumed by linguists and anthropologists alike, namely that a distinction can be made on the basis of whether particular referents represent the cultural stock of a speech community or not. I will not attempt to clarify the fuzzy boundaries in the lexis of the languages under discussion in this article. Instead, I will confine myself to items about which there should be unanimity as representing culture-specific behaviour other than the use of language as such, such as references to lifestyle, attitudes to human conditions, socio-political references, etc.

\section{Comparative description of macrostructural selection}

I shall now provide a brief description of the dictionaries investigated with a view to comparing their macrostructures. In this way I hope to reveal different perspectives and cultural biases as reflected in the selection of lemmas and contextual examples. The dictionaries to which I want to restrict myself, are the following:

- Afrikaans/Zoeloe-Woordeboek met Engelse Vertalings (Afrikaans/Zulu Dictionary with English Translations) - Kotzé and Wela (1991),

- Afrikaans-Japannese Aanleerderswoordeboek met Engelse Vertalings (Afrikaans-Japanese Learner's Dictionary with English Translations) - Sakurai and Kotzé (in preparation),

- The Greater Dictionary of Xhosa (Xhosa/English/Afrikaans), Part 3: Q-Z Pahl et al. (1989), and

- Bilingual Dictionary / Tweetalige Woordeboek (English / Afrikaans, Afrikaans / English - Bosman, et al. (1984).

The selection might seem somewhat arbitrary, but it is the result of having applied two criteria:

1. It should preferably be a dictionary that has been published recently (or is about to be published shortly), for a fair and valid assessment of cultural relevance to be made.

2. It should, of course, be a translating, and not a descriptive dictionary.

Another comment needs to be made: Although the title of this article makes mention of bilingual dictionaries, the concept of bilingualism as interpreted in the South African context stems from the previous political dispensation in which only English and Afrikaans were recognised as official languages. It was generally accepted that to be bilingual, one had to be fluent in these two official languages. In the hendecaglossic situation in which we find ourselves after 
1994, with eleven instead of two such languages, the new buzzword is multilingualism. An indication of the linguistic complexity of South African society can be obtained from the results of the 1990 census (cf. Appendix A). To be confronted with such an overwhelming variety of languages, all official, seems a daunting task to anybody dealing with the public, who are entitled to be served in any of these eleven languages. In practice, however, to be optimally communicatively competent as a South African amounts to being trilingual in most instances, since general usage of the new official languages is restricted, at least as far as mother-tongue speakers are concerned, to geographically circumscribed areas in each of the nine provinces. So one would find in the Free State a policy of trilingualism, with Afrikaans, English and Sesotho, in KwaZulu-Natal once again Afrikaans, English and Zulu this time, while in the Eastern, as well as in the Western Cape, Xhosa forms part of the triad instead of Sesotho and Zulu.

This acceptance of and adaptation to the realities of province-specific demographics seems to have been practised by some translating dictionaries as well. And if one looks at the macrostructural layout of the dictionaries mentioned earlier, it is only the Bilingual Dictionary of Bosman et al. that does not employ a third language, at least for the purpose of semantic cross-referencing (cf. Preface, Kotzé and Wela 1991). This is understandable, given the fact that the respective source and target languages were the only two official languages recognised as such from the time the Bilingual Dictionary was compiled in 1931 until the last revision in 1984.

\subsection{Afrikaans/Zulu Dictionary with English Translations}

This is a pedagogical or learner's dictionary, aiming at serving both school pupils and adult learners of two of the largest language communities in the country, with Zulu and Afrikaans being spoken as first language by, respectively, $22 \%$ and $15,9 \%$ of the population of South Africa in 1990 (cf. Appendix A). A careful selection had to be made to arrive at a limited total of between 13000 and 14000 lemmas. This limitation is compensated for in that illustrative examples of a large proportion of the macrostructural selection are provided. While the primary purpose of the editorial examples is to contextualise lexical items and to demonstrate the practical application of the lemmas in language usage, an investigation of the contents reveals in many respects a description of current political affairs during the last years of the previous decade in South Africa (Appendix B). Although the two main languages, Afrikaans and Zulu (English serving the purpose of a semantic tertium comparationis, as mentioned earlier in this paragraph), represent different cultures, the translation of cultural concepts did not pose insurmountable problems given the long history of contact between the speech communities, so that translating equivalents had an informal pre-existence before being "reduced to writing" in many instances. 


\subsection{Afrikaans-Japanese Learner's Dictionary}

This dictionary, which is presently in preparation, represents a new concept in South African lexicography, where for the first time a foreign lexicographic tradition is introduced in adapting a local product to the exigencies of a market which has never been catered for before. Although this dictionary is roughly based on the macrostructure of the Afrikaans/Zulu Dictionary mentioned above, the target group in this case is quite different, consisting of business people, tourists and, to a limited extent, tertiary students. Coupled with the fact that a particular African and an Asian culture are juxtaposed through the medium of a Germanic language, it represents indeed an unusual combination. The cultural barriers, unlike in the case of Afrikaans and Zulu, called for much more drastic measures to achieve pragmatic equivalence, simply because no frame of reference existed to interpret certain lemmas for the Japanese user. Ostensive addressing, i.e. the use of graphic illustrations, which is common practice in Japanese translating dictionaries, is practically unknown in the South African context, and the available selection of lemmas had to be addressed exclusively in the textual mode. This entailed a much higher proportion of defining translations which is normally a feature of descriptive cultural dictionaries. The microstructure also makes provision for both the linguistic and orthographic distance between the two languages by providing a phonetic transcription of each lemma and a Romaji (i.e. Romanized) version of each translation equivalent and illustrative example (Appendix C).

\subsection{The Greater Dictionary of Xhosa (Part 3: Q-Z)}

This is a cultural dictionary in the full sense of the word. It is both a descriptive and a translating dictionary, in the sense that each lemma is addressed by a definition in Xhosa in the first column of each page, while two further columns are devoted to translating equivalents and/or translating definitions in both English and Afrikaans, respectively (Appendix D). Numerous editorial examples are provided which are also translated in the columns for English and Afrikaans. The dictionary section of this volume covers 681 pages, with 51 addenda containing grammatical commentaries and a description of a wide variety of customs and traditions typical of Xhosa culture. The foreword, for example, contains the following comment by the Vice-Chancellor of the University of Fort Hare:

The compilers of this Dictionary have succeeded in capturing much of the living breath and feel of the Xhosa world. Here is no mere cold analysis, but a work that breathes the life of the Xhosa peoples themselves. (1989: viii) 
The main purpose of the dictionary is to serve as a comprehensive source of reference for students of Xhosa.

\subsection{Bilingual Dictionary}

This is a relatively comprehensive dictionary, containing some "300 000 words and expressions" (according to the cover text). Because of its long history, the macrostructure contains several socio-political and other cultural references, some of which have disappeared from current usage, or have become stigmatised because of derogatory connotations. The majority of illustrative examples, however, are culturally unmarked, and, from a linguistic viewpoint, rarely extend beyond two- or three-word collocations and compounds, not providing much grammatical guidance as to how the lemmas are to be used in larger constructions, such as independent phrases or sentences (Appendix E). The Bilingual Dictionary has been the subject of much metalexicographic analysis, and has gradually been adapted to reflect linguistic and social changes in the speech communities it serves, but the discussion is far from being exhausted.

\section{Translating equivalents as textual items in the context of culture}

Although general principles for the compilation of translating dictionaries have been proposed by some authors (cf. Al-Kasimi 1983), hard and fast rules do not exist and would be unfair to apply to any such dictionary in an arbitrary way, given the variables pertaining to each case individually. However, it would be possible to investigate the dictionary articles in the light of certain standards of textuality to determine the pragmatic success of particular articles as texts. The success of any text depends, for instance, on the question whether the reader can identify the purpose for which the text was created (i.e. the principle of intentionality), on the effectiveness with which the information is transmitted (i.e. the principle of informativity) and on the question whether the target user would interpret the text in the way in which it was intended by the author (i.e. the principle of acceptability). In the remainder of the article, these principles will be briefly applied to the category of dictionary identified above, and it will be shown, particularly with reference to the second and third principles, how they can apply to dictionary texts in practice.

3.1 Information on interlingual and intercultural problems stated in the foreword

The purpose for which a dictionary text has been compiled is normally explained in the explanatory notes, both for marketing purposes and to create a fair level of expectancy as to what could reasonably be achieved by using the text and what not. One of the most important objectives of this explanatory 
section is the description of the target user(s), because the dictionary compiler is thereby committing him-/herself to addressing the needs of the user and providing any would-be evaluator with a framework by means of which the value of the text can be assessed. In the case of the dictionaries involving target users from a different cultural background than that of the language from which the lemmas are selected, it could reasonably be expected that allowance should be made to bridge the gap in a strategically sound and possibly structured way. Of course, difficulties stemming from the way meaning is structured and presented in a particular grammatical form should also be considered in deciding on the format of dictionary articles where typologically divergent or anisomorphic languages are involved. This was the topic of another article (Kotzé 1992) and the examples extensively quoted there will not be repeated here. What emerged from the investigation reported is the fact that a didactic function can be fulfilled by systematically alternating structurally different translating possibilities. For instance, when a copula plus adjective in Afrikaans can be translated by means of an intransitive verb or a relative construction in Zulu, the choice should be reflected in the proportion of examples offered. Similarly, phrasal verbs in Afrikaans are normally written as one word in conjunction with modal auxiliaries, but separated in different ways when used as the only verb in the sentence or in the past tense. The didactic purpose served by alternation should be evident in cases like these.

\subsection{Principles of textuality and the translation of "cultural" items}

The principle of intentionality is something that can be assumed to be adhered to when we consider the strict format according to which most dictionaries are compiled, whether implicitly or explicitly, because it relates directly to the level of informativity and acceptability. Consequently, these three factors codetermine the successfulness of the publication. We first tum to the principle of acceptability. Cultural differences between source text readers and target text readers play a role," according to Lukasz Bogucki (1996: 107), "and the notion of acceptability is central to the issue in question."

Sometimes, acceptability does not depend on the cultural-semantic content conveyed by the translation equivalent, but rather on the register selected within the lexicon of the target language. In the Afrikaans-Japanese Dictionary mentioned above, for example, it would be inconceivable to supply a direct translation for the lemmas blind, doof and stom (blind, deaf and dumb), since in Japanese culture, reference to these conditions require euphemisms, mekura, tsumbo and oshi (Appendix C), roughly equivalent to "visually impaired", etc.

The question of register acceptability is not confined to interlingual translation of lexical items. In the Nguni cultures (cf. the language groupings in Appendix A), the linguistic correlate reflecting the respect which a married woman is expected to demonstrate towards her male relatives-in-law takes the 
form of a special altemative vocabulary called hlonipha. This word is defined in A Dictionary of South African English (Branford and Branford 1991):

The system of reverence and taboos observed by the Nguni woman towards her male relatives-in-law, involving ... a whole substitute vocabulary of hlonipha words enabling her to avoid speaking the radical syllable of any one of their names [...]

An example from the Greater Dictionary of Xhosa is inteleko (pot) (Appendix F), which has to be translated in all three languages, together with a label to indicate its special use: (hlonipha, feminine). Even if the lexicographer is supplying a surrogate equivalent in the translating entries, the article has to contain an additional microstructural treatment of the lemma (in other words, additional lemmatic addressing) to ensure the retrieval of the correct information (Gouws 1996: 27). In this case it is a clear indication of the register to which the lemma is applicable.

For a bilingual dictionary to function as a practical linguistic instrument (which could be regarded as one of the objectives of such a dictionary) in a multilingual and multicultural society, the information transfer has to be focused on pragmatic aspects (Gouws 1996: 28) to ensure not only the informativity, but also the acceptability principle of the translation equivalent. There is a fundamental difference between the demands of foreign language users and those of native speakers, and this fact has to be recognised in the method of addressing, so as to render the information in the dictionary accessible to the intended user. Nonlemmatic addressing (by means of glosses, collocations, illustrative phrases and sentences, the explanation of meaning as well as ostensive addressing, i.e. pictorial illustrations) adds communicative value to the article.

Acceptability can, however, often also be hampered by incongruence problems between the culture-specific meanings of lexical items of different languages and the impossibility of establishing full or partial lexical equivalence between such culture-bound lexemes. Chaffey (1992: 147-153) uses the term degree of cultural loading to refer to the amount of culture-specific knowledge or information a language-user must have in order to be able to understand what we might loosely call the full meaning of a lexical item. One area of the lexicon of any given language that has an extremely high degree of cultural loading is that of legal terms. Even identical terms used by speech communities which do not belong to vastly different cultures might be interpreted differently and lead to fallacious deductions. One example from the dictionaries referred to earlier is the translation of the word ukuthwalwa in Xhosa, which has no other lexical equivalent in English than "to abduct" (Appendix G). In Xhosa culture (as in the Zulu context), abduction can be a perfectly legal action, agreed upon by both the parents of the young man and the girl involved. This 
semantic divergence can only be dealt with satisfactorily by means of a nonlemmatic address, so that the culture-specific meaning becomes clear.

Lastly, the acceptability of a translating equivalent is very often determined by associative or connotative meanings attached not only to translation equivalents, but also to the lemma itself. Lexicographers are often confronted with the question: Must I include this socio-politically or racially sensitive item or not? This is one of the most difficult areas in lexicographical practice, and dictionary compilers have reacted to the challenge in various ways. If one applies the standards of textuality, acceptability is here largely dependent on intentionality. If the intention of the lexicographer is not clearly spelled out, the mere inclusion of an offensive term will lead to a breakdown of the communication process. If the intended user is not likely to accept the objectivity of the author, no amount of nonlemmatic addressing will salvage the informativity of the article. This is probably the reason why, in the case of a publication aimed (albeit partially) at school-going users such as the Afrikaans/Zulu Dictionary, potentially offensive items have been left out, while in the case of a dictionary intended for adult users, the items are included, but with conspicuous labelling as can be illustrated by the lemma kaffer in Bilingual Dictionary (cf. Appendix $\mathrm{H})$. However, in the case of editorial examples instead of corpus quotations, these examples can be said to be the creations of the compiler, reflecting his/her thinking, and whether this is justified or not, the perlocutionary effect on the user will determine the way the intentionality of the text is assessed. If the inclusion of such examples causes offence, the acceptability of the text is jeopardised. This is probably one of the reasons why the Woordeboek van die Afrikaanse Taal (Dictionary of the Afrikaans Language), a comprehensive descriptive dictionary, decided not to include potentially offensive illustrative examples, even though they are corpus quotations, in the hardcopy edition, but to retain them in the unpublished electronic manuscript exclusively for research purposes (Harteveld and Van Niekerk 1995: 249-266).

\section{Conclusion}

It seems then that the concept of translation in the context of lexicography comprises a variety of dimensions, more intricate than is normally assumed. This becomes evident as one analyses in translating dictionaries not only the process of interlingual transfer of meaning (lexical or pragmatic) and the allimportance of the cultural framework in which it is interpreted, but also the dictionary article as a unit of discourse which can be assessed as a text according to standards of textuality. In the process, the dictionary becomes the reflection of the compiler's view of social reality expressed in the format collectively laid down by the discipline at large, and thus a cultural artefact of the community concerned. 


\section{Note}

1. In recent discussions (e.g. Du Plessis and Bosch 1999: 16) it is argued that the term text linguistics should be substituted by a more comprehensive term, such as discourse linguistics, and that De Beaugrande and Dressler's seven standards (principles) of textuality should be modified to two superstandards, viz. cohesion and coherence, which include the other five. I would like to demonstrate, however, that some of the "subsidiary" standards could also operate independently in contributing to the textuality of the discourse under discussion (in this case a dictionary article).

\section{Bibliography}

Al-Kasimi, Ali M. 1983. Linguistics and Bilingual Dictionaries. Leiden: E.J. Brill.

Becher, Gabriele. 1995. Culture and Institutions in Translator Training. Teaching Culture-specific Concepts to Prospective Translators; a Case Study. Thelen, M. and B. LewandowskaTomaszczyk (Eds.). 1995: 293-304.

Bogucki, Lukasz. 1996. On Rendering Register. Lewandowska-Tomaszczyk, B. and M. Thelen (Eds.). 1996: 107-111.

Bosman, D.B. et al. 1984. Bilingual Dictionary / Tweetalige Woordeboek (English/Afrikaans, Afrikaans/English). Cape Town: Tafelberg.

Branford, J. and W. Branford. 1991. Dictionary of South African English. Cape Town: Oxford University Press.

Carstens, W.A.M. and E.H. Hubbard (Eds.). 1993. Tekslinguistiek / Text Linguistics. S.A. Joumal of Linguistics, Supplement, 15 May 1993.

Chaffey, William. 1992. Culture-specific Elements in Translation. Lewandowska-Tomaszczyk, B. and M. Thelen (Eds.). 1992: 147-153.

De Beaugrande, R.A. and W.U. Dressler. 1981. Introduction to Text Linguistics. London: Longman.

Du Plessis, Wilhelm and Barbara Bosch 1999. ' $n$ Sinchroniese beskouing van diskoerslinguistiek. S.A. Jourmal of Linguistics 17(1): 16-36.

Gouws, Rufus H. 1996. Bilingual Dictionaries and Communicative Equivalence for a Multilingual Society. Lexikos 6: 14-31.

Harteveld, P. and A. van Niekerk. 1995. Policy for the Treatment of Insulting and Sensitive Lexical Items in the Woordeboek van die Afrikaanse Taal. Lexikos 5: 249-266.

Kotzé, E.F. 1992. The Lexicographical Handling of Grammatical Equivalence: The Case of Afrikaans and Zulu. Lexikos 2: 137-147.

Kotzé, E. and P. Wela. 1991. Afrikaans/Zoeloe-Woordeboek met Engelse vertalings. Cape Town: Tafelberg.

Lewandowska-Tomaszczyk, B. and M. Thelen (Eds.). 1992. Translation and Meaning, Part 2. Maastricht: Universitaire Pers.

Lewandowska-Tomaszczyk, B. and M. Thelen (Eds.). 1996. Translation and Meaning, Part 4. Maastricht: Universitaire Pers.

Pahl, H.W. et al. 1989. The Greater Dictionary of Xhosa (Xhosa/English/Afrikaans), Part 3: $Q$ to Z. Fort Hare: University of Fort Hare Press. 
Petöfi, J.S. 1990. Language as a Written Medium: Text. Collinge, N.E. (Ed.). 1990. An Encyclopedia of Language. London: Routledge.

Renkema, J. 1993. Discourse Studies. An Introductory Textbook. Amsterdam / Philadelphia: John Benjamins.

Sakurai, T. and E.F. Kotzé. In preparation. Afrikaans-Japannese Aanleerderswoordeboek met Engelse Vertalings. Tokyo: Daigaku Shorin.

Thelen, M. and B. Lewandowska-Tomaszczyk (Eds.). 1995. Translation and Meaning, Part 3. Maastricht: Universitaire Pers.

Toury, G. 1980. In Search of a Theory of Translation. Tel Aviv: Porter Institute.

Van Dijk, T.A. 1985. Handbook of Discourse Analysis. London: Academic Press. 
Appendix A

Distribution of Languages in South Africa - 1990 Census

Languages

\section{Number of \\ L1 Speakers}

Former official languages

Afrikaans

English

6188981

3432040

15,90

8,80

Nguni languages

Zulu

Xhosa

Swazi

Ndebele

Sotho languages

Tswana

Sepedi

Sesotho

Tsonga

Venda

Other languages

Portuguese

German

Greek

Italian

Dutch

French

Hindi

Gujarati

Tamil

Urdu

Telugu

Chinese

Other

Total

$\begin{array}{rr}8541173 & 22,00 \\ 6891358 & 17,70 \\ 926094 & 2,40 \\ 799216 & 2,10\end{array}$

$3601609 \quad 9,30$

$3437971 \quad 8,90$

$2652590 \quad 6,80$

$1349022 \quad 3,50$

$763247 \quad 1,90$

$57080 \quad 0,15$

$40240 \quad 0,10$

$16780 \quad 0,04$

$16600 \quad 0,04$

$11740 \quad 0,03$

$6340 \quad 0,02$

$25900 \quad 0,07$

$25120 \quad 0,07$

$24720 \quad 0,06$

$13280 \quad 0,03$

$4000 \quad 0,01$

$2700 \quad 0,01$

$22740 \quad 0,06$

$38850541 \quad 100,00$ 


\section{Appendix B}

\section{A Selection of Articles from the Afrikaans/Zulu Dictionary with Eng- lish Translations}

beeld ( e) s.nw. isifanekiso (image); 'n skewe van die land isifanekiso esibi sezwe (a skew image of the country)

diensplig s.nw. ukubuthwa emasosheni [okuphoqelekile] (conscription, military service); hy doen militêre ubuthwe emasosheni (he is doing military service)

dienspligtige ( s) s.nw. isosha (national serviceman); dienspligtiges help soms die polisie amasosha abuye asize amaphoyisa (national servicemen sometimes assist the police)

diskrimineer $w w$. bandlulula (discriminate); diskriminerende wetgewing umthetho obandlululayo (discriminating legislation)

etnies ( e) b.nw. =phathelene nokwahlukana kwezinhlanga, =obuzwe (ethnic) 1. die etniese verskeidenheid ukwahlukana kwezinhlanga (the ethnic diversity) 2. sy trek aan ugqoka ngokobuzwe bakubo (she dresses in ethnic fashion)

front ( e) s.nw. ikhala lempi, ugange (border, front) 1. die soldate veg aan die amasosha alwa ekhaleni lempi (the soldiers are fighting at the border) 2 . hulle vorm 'n verenigde bakha ugange oluhlangene (they form a united front)

frontlinie ( s) s.nw. ugange olungaphambili (front line); die Frontliniestate amazwe angongqa phambili (the Front Line states)

geweer (gewere) s.nw. isibhamu (gun, fire-arm) 1. na die gryp dumela isibhamu (take up arms) 2. presenteer $\sim$ ! viva! (ekv.) vivani! (mv.) (present arms!)

geweld s.nw. udlame, indluzula (violence, force) 1 . hulle moes $\sim$ gebruik kwadingeka basebenzise udlame (they had to use violence) 2. die onrus is met $\sim$ onderdruk uthuthuva luqedwe ngodlame (ngendluzula) (the unrest was suppressed by means of force)

groepsgebied ( e) s.nw. ind awo ebekelwe isizwe esithile (group area)

halssnoer ( e) s.nw. umgexo (necklace)

halssnoermoord ( e) s.nw. ukugaxa ithayi (necklace murder)

hoofman ( ne) s.nw. induna (headman, chief)

hoofminister ( s) s.nw. undunankulu (chief minister)

instroming s.nw. ukuthutheleka (inflow, influx)

instromingsbeheer s.nw. ukuvimba ukuthutheleka kwabantu (influx control)

inval ( le) s.nw. ukuzuma (invasion, raid); die Weermag het ' $n \sim$ in Angola gedoen umbutho wezokuvikela uzumisile eAngola (the Defence Force invaded Angola)

kleurbeleid ( e) s.nw. inqubo yokwahlukanisa ngebala (colour policy) 


\section{Appendix C}

\section{A Selection of Articles from the Afrikaans-Japanese Learner's Diction- ary with English Translations}

baie [báie] b.nw. 1. 多くの ooku no (many, much); mense 大眵の人 oozei-no hito; vrugteたくさんの果物 takusan-no kudamono; bietjie pp多 W yaya ooi (rather

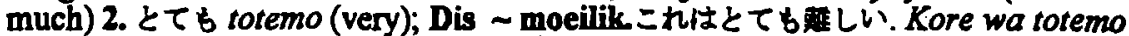
muzukashii.; Dis minder. これ性すっ と少ない. Kore wa zutto sukanai. (much less); 〈成句〉一 dankiel とうちあり㘦とうこざいます. Doumo arigatou gozai masu (Thank you very much.) 3. しばしば shiba-shiba (frequently); Dit gebeur 〜 それんしぱしば起 $=3$. Sore wa shiba-shiba okoru.

baku [bak] b.nw. 1. 状の hachi-jou no; Jou hande maak! 两手を菜确型にしなさい.

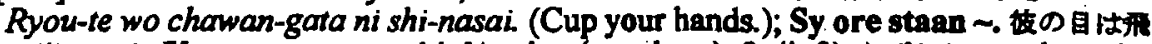
ひயている. Kare no me wa tobi-déte iru.(stand out) 2. (inf) オばらしい subarashii (fine); Dit gaan 〜. バッチリだ. Batchiri da. (Everything's fine.); Hy is 'n ou. 佊はい い奴だ. Kare wa it yatsu da.

bake [bak] (-ke) s.nw. hachi (bowl, trough)

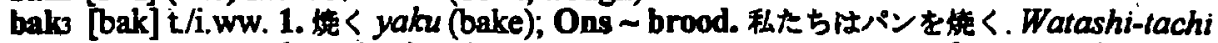
wa pan wo yaku; die eiers in die pan フライバンで卯を烧く furai-pan de tamago wo yaku 2. 日に凂ける hi ni yakeru (bask); Ek heerlik in die son. 私はきれいに日炟 けす万. Watashi wa kirei ni hi-yake-surn.

baken [baikən] (-s) s.nw. 1. 土地の自月 me-jirushi (landmark) 2. ヒーコン biikon (beacon) bakker [bákər] (-s) s.nw. パン屋 (人) pan-ya (baker)

bakkery [bakəráj] (-e) s.nw. パン 量 (店) pan-ya (bakery)

bakkie [báki] (-s) s.nw. 1. 小型トラック kogata torakku (light truck, bakkie); 'n is 'n nuttige voertuig. 小型トラック驻便利な涞り物だ. Kogata torakku wa benri-na

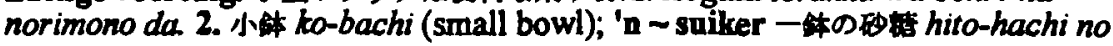
satou

bakkies [bákis] (-e) s.nw.,inf. $つ ち$ tsura (face, phiz)

blind [blont] ( -e) b.nw. 亩目の moumoku no (blind)

doof [doof] (dowe) b.nw. 耳の不自由な mimi no fu-jiyuu-ne (deaf); Dis 'n dowe hind これは耳の不自由な子垬だ Kare wa mimi no fu-jiyuu-na kodomo da.; Die geraas maak my 〜. 䖪音で耳が䦥こえなくなろ. Souon de mimi ga kikoe-naku naru.

stom[stom] ( , mo) b.nw. 1.ロのきけない kuchi no kike-nai (dumb); Die man is 〜. その男は㕵者だ. Sono otoko wa a-sha da. 2. 育れな aware-ne; Dio stomme kindl 产れな子. Awrare-na ko!(The poor child!) 


\section{Appendix D}

\section{An Example from The Greater Dictionary of Xhosa}

fn.tenity b/n 9/10: 1 umvindla abumfusa, obukhulu neendlebe zinganeno kwerikaholweni; uhlala ematyeni; Pronolagus mpestris:

2 umdlalo wetenese:

ukubuya noboyo bentenetya: ukungaphumeleli kwi. njongo yakho; ukubuya ze:

fn-tengiselwand b/n 9/-: urhwebo, isenzo sokuthengiselana phakathi kwababini nangaphezulu, phakathi hwezizore ngezizwe:

fo-tenged b/a 9/10: 1 isenzo sokunikexela into ngenjongo yokufumana imali:

2 uthengiso twempabla ngamaxabiso angaphantsi kwalawo abeqhetetile; iseyile:

3. uthengiso twezinto agokushiyiselana kwabathengi ngamaxabiso; ifandesi:

fo.tingt b/n 9/10: intaka emnyama ethanda ukutya iinyosi nezinye irinambrome, Dieruns adsimili; ithi ra ithalayo: ntengu, ntengu, maceryana, ixe maza wambi yendule ithi: kazi ukuba benze moni na abo. nnwana benkosi, Nombande (G):

\section{"kwaluswe yisuengu. $\mathbf{k g l}$ ukwaluswa.}

indoda engenamalusi inkomo zayo zaluswa yintengu: kgl umalust:

f- thentive b/n $9 / 10<$ Af tentwa; inqwelo enetentyi (G):
1 red hare, Smith's red rock mbbit, Pronolagus rupestris;

2 tennis;

fiil in an undertaking; see uboya.

reciprocal business, commerce, trade.

1 sale, eg of home-made goods to gather funds;

2 sale, is the selling of goods at reduced prices;

3 sale by auction.

forktailed drongo, Dicrerus adsimilis, called intengu from its ery nuengu niengu macervana, to which is somecimes added: $I$ wonder whas the children of the chicf have done (G);

sec ukwalurwa.

see unalusi.

tent-wagon (G).
I rooihaas, kliphaas, Smith se rooiklipkonyn, Pronologus rupestris;

2 tennis; onverrigter sake terugkeer; sien uboya.

wedersydse handel.

I verkoping, bv rat tuisgemaskce eerware en artikels om fondse in te samel;

2 uitverkoping, bv deur 'n kJerewinkel;

3 vendusie, veiling.

mikstertbyvanger, Dicrums adsinilis; sy nagm is afgelei van die geluid wat hy maak, weergegee as nengu ntengu mace. tyana mara an soms toegevoeg word: et wonder wat die stamhoof se kinders ansgevarg het (G);

sien ukwalunwa.

ryta unalusi.

tentwa (G). 


\section{Appendix E}

\section{An Example from Bilingual Dictionary}

Klot teir gè. clang, clash, rattie (arms); pat. ter, pelt, clatter ( rain) . thet'terend es clang. ing, clashing; partering, pelting, clattering. teur $\mu, \pi$. colour(ing); tint; tincture; colo(u)ration; hue; complexion (of face); shade; suffusion; suit ( of cards); timbre ( of muric s; stain(ing), dye, oaint; behes follow suit (in game of cards) ahow one's true colours; 'n ander $~$ gre aan put a dif. ferent (new) face on; 'n modern' - can iets get give s.t. a modem slant; 'n skerper gee tone up; - hou not fade, have fast colour(s); in $\sim(e)$ in colour; ' $\pi \sim h r y$ colour (up), fush, go red in the face; pati. tieke - political complexion; alle ve van die rezimboos atl the colouts of the rain. bow, every hue in the paintbox; van - vor. ander turn one's cost (in potitica); - ver Lem lend colour; - werloor bose c.; ver. mah renounce, revole, not follow suit; yan - orrokiet change (lose) colour; jou - (e) wys show one's true colour (colours). $V i d$. eour. kleur ge, colour; dye, stain; tint; suffuse; tinge; tone; dit - daorby this colour tones writh that, this colour matches that; minder sherp - tone down; te sterk - over-colour, overpaint; overdo, overstate, paint the lily. -atenwending use of colour. - edviever colour consultant. - fowlewilng tonality; variegation. ansdlle blazer. arod toning-buth beele colour base. r beteld c. policy. bewue c.-canscious. -bowutheld c. consciousness. -blind c-blind, mo. nochrometic. bindo is monochromat. allndhotd c.-blindness, achromatopsia greoone - daltonism; oolrlar monochro matism. thur der at dyes; stainet. olle os, diepattiat colour stide, transparenicy: oid. Heuretryfle. odiept c. intensity. drenking impregnation. drul $c_{4}$ printing. -o trid. Mlouhoudend. -

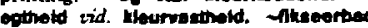
toning and fixing bath. Alm cotour film

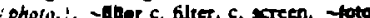
'natural) c. phoro(graph). - potogiatle c. photography, photochromy, hetiochromy. zaringetof garn-dyed fabric. agantine trpy ingrain creper ravool colour sense, chromatic senve; colour-consciousness. geroelin se colour-sensitive, chromosen. itive; orthochromatic (plate). nevoella. hald colour-sensitiveness, chromosen: sitiveness; colour-cansciousress, nomend \& colorific. wawtng colo(u)rotion. olas stained glass. - houdand af fadeless, un faling, fast-dyed (-coloured), colour-fast die stof is - the material has fast colour (is fodeless). Mlevirh $\sim$ many-coloured cotourful, gay-phumaged, gay i cloches ; , full

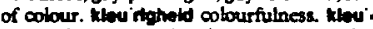
ing coloration, colouring, dyeing, stain ing, tinting, pigmentztion. -haant colour aclas or chart. - talk colour wash. =tontres colour contrast.

hlour: - thry coloured chalk, heep colour coax. - lapple flash. K-ling ie (Cape) Coloured person. Aing ef coloured person person of colour. Alisoratie chromo. lithography. Wleur'loos lase colouriess, achromatic; complexionkess; drab lijes; -

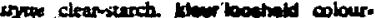
lesuness, achromarism; drabnesy. -manging colour-blending. -meter colorimeter, tin. cometer. middal as colouring agent, pig. ment, colouring-matuer, tint. a nuamentng tonality. - paseer colour-metcher. ptan colour(ed) plate, reproduction in colour. plaenfle colour slide, transparency; small colour(ed) plate. potlood colouring pencil. prent colour(ed) print; colour film; vid. klourrotprem. proses dyeing process. rasm colour frame. rolprem film in colour, colour film lainrma l: vid. kleurperent. arit es richty coloured, colour. ful, dowing (with colour). Hteur'el is colouring (matrer); distemper; dye, pig. ment. -in sense of colour, chromatic sense. -hant colour-seale, chromatic cale. Atatering variation of colours; shade (of colour), nugnce, hue, inge.

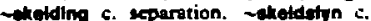
line. Atern c. scheme. werm c. sereen. - ahining c. dispersion; spectum. q etryte c. slide, imonsparency; vid. traundis; mour. Hantite raky c. disc (disk), (c.) filter.

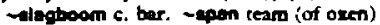
of one c.. -epatiel splath of c. -epolng play of colours, iridescence (irisarion).

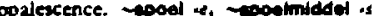
rinse. -opoel ge- rinse (hair), uteendrut chromolithograph; chromolithography. - cteendrukzune chromolithography. uttil (coloured) crayon colouring matter, pigment, dye(stufn), stain. - itof. labriek dye-works. arter cotour index. toon c. cone. trot n. c.-conscious ness. -trote c.-conscious. Awmating twist yam, a res vid, kleurhoudend. - whe hald colour-fastness. weals touch of $c$. r venter stained-glass window. -weren. derend versicolour(ed). r verandering chenge of colour. r vertilanking colour phonism. wet block tibre (in 2000l). - viles uvea. woating bleeding. - wavo. stuk colour question. werk dyeing. -wisestend versicoloured). -wiase fing rid. klourowisesting. $\rightarrow$ wat black wool.

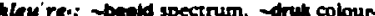
printing, chromatography; chromograph, chromotype. - etiek colour effect. ramme c. range, c. scak; shade card. rloed blaze of $c$. . Thermonie $c$. harmony, chord of c., c.-chord. - (e)kent c. card; tint card. N wor chromatics, chromatology. ameng(el)ing blending of colours; iridescence (irisation). manener colour cand. areg blaze (feast, orzy, riot, splendoup) of colour(s). ntedon wealth of colour(s). -epehtrum colour spectrum, chromatic spectrum. repl ptry of cotours, iridescence. - (o)wteselling change of colour(s), inidescence.

leu'ter as tor, infant, kid(dy), pre-xchool child. boek nursery book. - hilas infone class, nursery class. - akool nursery school, infant (pre-primnry) school. wad baby talk, babbling-language, "little" lenguage, kte'we gex, vid, kbet. Who' wend st fixative, glutinous, sticky. blow is sticker. th werid adbesive, clogsy, booey, gummy, scicky, ghuey, viscous, viscid, glutinous, tacky; siry; clammy (hands): -

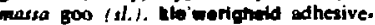
ness, stichiness, glucyness; viseosiry, gum. miness. tactioses, viscidity, lubricity $/$ of oili; chmminess (of hasts). the wing clinginess (of moot).

kls'za ge. milt into ane's mourh

klliel ge. eleave, split; plough, breast the oava): slice (gir); cut. Iud has bare clevable. Htitbartald clavage (min.), clearability. - Nalk cleavege plane.

Lftek $\sim, n$. clique, corerie, act, party, clan kllek ge: form a clique (coterie, junto, set) 


\section{Appendix F}

\section{An Example of Hlonipha from The Greater Dictionary of Xhosa}

\author{
1.taid b/n $9 / 10<A f$ trek: ukuthwalwa kwempahla \\ yomri ifutukele adameni yimbi nabaniniyo; imfu- \\ duta, imfuduko, ufuduto; utumka ngenqwelo ku- \\ thwelwe impahin yomsi uphela; itorho; uphumeto \\ threlipe if

\section{fo bulato b/n 9/10: blon f: imbiz:

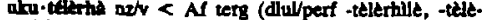

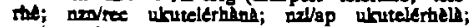

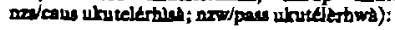 \\ uknkorhola, uruqbula, ukutagla, ukudiallea ngomntu, ulutereths, urubhotolosha;}

\begin{tabular}{|c|c|}
\hline $\begin{array}{l}\text { trek, migration, journey by wagon with } \\
\text { all ane's belonginge }\end{array}$ & $\begin{array}{l}\text { trek, verhuising, volksve } \\
\text { ossewa na 'n ander oar } \\
\text { se besitrings. }\end{array}$ \\
\hline hlon f: pot & hlon v: kospot, tastrol. \\
\hline tease. & terg, treiter, vernondig. \\
\hline
\end{tabular}

\section{Appendix G}

\section{An Example from one of the Addenda to The Greater Dictionary of Xhosa}

\section{Ukuthwalwa kwentombi}

\section{Abduction of a girl}

This is one of the ways in which a girl is introduced to the wedded state. It is resorted to in certain circumstances, eg when an old man is in need of a wife, or a young man is afraid that he will lose the girl to mother suitor, or the family of the young man is not in a position to afford the expenses of a formal marriage.

When the families concerned have agreed on the terms of the lobola. (bride price), the representatives of the suitor ask for permission to abduct the girl and if her family agree they indicate where and when the girl might be surprised and carried off. On the appointed day her family send her somewhere under a

pretext, while young men from the prospective bridegroom's home lie in wait for her, pounce upon her and take her to her new home.

However, this may also be done without prior consultation with her family. In such a case the bridegroom's father sends a message to her home asking her parents not to search for their lost daughter as she has arrived at her new home as a daughter-inlaw, and to discuss the terms of lobola. Among the dowry cattle to be paid is one known as inkomo yamabhayi, the beast of the blankets, which is the one specially handed over to her family for her abduction. 


\section{Appendix $\mathbf{H}$}

\section{An Example of a Lemma from Bilingual Dictionary}

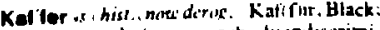
- Afore "n insuaur evershondy indiscrimi notely $k$-bal $K$. sheteting. -boes K. cou notely. Kafinir (Native cartle. W-beele (ox): Ml. Kofinir Sative cattle. Wbetele phili e), negruphilist. L-bom $K$. tree. phili eirom, coratirec Enthrina cuffra.: Errithrine spp. t-boon(ijte) K. hean. blick-eved than, cou-pes. Iipna sinemisx. black-eyed hean. cou-pes Iipnusinenisx. (lincrethalariss spp.! -bruld $K$ bride (Puicetsa spp.' t-doring K.-thorn tree Livitm firrondum. . M-drulwe K.-grapes Pillichid cumperins. t-all Bushmon's poison. - hoof hill K. (Nativel chief. pain intrambre Puihupodium spp.. trop. idn hish . K. Netive chief t-toring $k$ corn, grain werehum. Sorghom isffrorum: . Turkish miltet, puinea-eom - kreal : hst.
\end{abstract}

K. kraal. Native village. -krabe Sinecto ar thulusus. - tand hist. Kaffirland; Kaf, fruria: hy dink hy is told iun - he thinks himself the ca's payamas or whiskets k-lomoen Strichus spp. k-manne $k$ millet. - nesie : hust. K. nation. Native puople. -oorlog hist. K, war. =op. perhood hisl., K. Native chief tam. Native rules. h-pal coll., good hiding (thrashing . souns theating i wallop, whop? Arubhing, pasting, trouncing, hammering: - Rrc trounce. k-potke. k-pokkies milkfax: alastrim, Kafifir pox, pacudarmall pox. M-pruim Kaf, fur plum Hurnephic liom isjerum . K-Elangwortel tSTc of u-jld

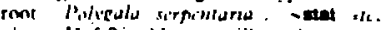
- Mrt. Kaffir iNatue village -suring Kafifiar morrel Piduresumm piliultum -toel hist. Kaf. fur. Hantu language. native languagt. h-tee kafefir ted planrs. Kat tortio .3. Mist., Wowe dirof. litele Kaf, fjir, Native tons, piccanineny, i wy (in. - ! my little darling!. Int tortio ,

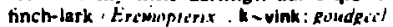
- golden bishop:-bird; rid. goudvint: Kuspse - Cape !yellin-rumped, Hitow abirdi, end oevikruisuinh: rou - red hishop-hird), ild. roolvinh. k-weat lomoen. l-wetertomoen Kafir mitun

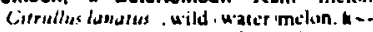
wao-'n-biet/ie(-0oom) Kaf fir-1horn

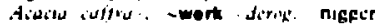
work. k-mortel pilerwot. kal terskuil bul ruhbick.

Kaftra rië Kafiraria. Cofirara. Kaflra riee a. - Kafigarian. Cuffrarian.

Kafir * Kafit misupllamt of Kuflrt:lum Kaft ristan Katipustan. 


\section{Access Structures in a Standard Translation Dictionary"}

Phillip Adriaan Louw, Department of Afrikaans and Dutch, University of Stellenbosch, Stellenbosch, Republic of South Africa

Abstract: The access structure is the primary guide structure in the central texts of any standard translation dictionary. The metalexicographical term "guide structures" refers to the set of structures that provides a framework within which the accessibility and availability of information types in the dictionary can be evaluated.

The access structure is, however, not a singular entity. It includes certain substructures, of which the outer and inner access structures are the most important. In this article the status quo with regard to access structures in standard translation dictionaries with Afrikaans and English as treated language pair will be evaluated. Suggestions will then be made as to possible improvements.

In the discussion of the outer access structure it is suggested that the rapid outer access structure be improved by using an elementary thumb index and that the current system of running heads be retained. For the standard outer access structure a better planned and motivated system of ordering homonyms, as well as a more consistent initial alphabetical ordering is suggested.

The focus in the discussion of the inner access structure will be on improving the rapid inner access structure by an innovative use of typographical and non-typographical structural markers. Better systems of ordering information subtypes within information categories are suggested as an innovation in the standard inner access structure.

Broad guidelines are therefore given to improve dictionary accessibility and enhance userfriendliness through improved access structures.

Keywords: ACCESS STRUCTURE, DICTIONARY, DICTIONARY ACCESSIBILITY, HOMONYMY, INNER ACCESS STRUCTURE, INNER SEARCH PATH, LEXICOGRAPHY, METALEXICOGRAPHY, OUTER ACCESS STRUCTURE, OUTER SEARCH PATH, POLYSEMY, RAPID INNER ACCESS STRUCTURE, RAPID OUTER ACCESS STRUCTURE, STANDARD INNER ACCESS STRUCTURE, STANDARD OUTER ACCESS STRUCTURE, STANDARD TRANSLATION DICTIONARY, STRUCTURAL MARKER, USER-FRIENDLINESS

Opsomming: Toegangstrukture in 'n standaard vertalende woordeboek. Die toegangstruktuur is die primêre gidsstruktuur binne enige standaard vertalende woordeboek se sentrale tekste. Die metaleksikografiese term "gidsstrukture" verwys na die groep strukture wat 'n

This article is based on a paper read at the Third International Conference of the African Association for Lexicography, held at the Potchefstroom University for C.H.E., Potchefstroom, 29-30 June 1998. 
raamwerk verskaf waarbinne die toeganklikheid en bereikbaarheid van inligtingstipes in 'n woordeboek geëvalueer kan word.

Die toegangstruktuur is egter nie 'n ondeelbare entiteit nie. Dit sluit sekere substrukture in, waarvan die eksterne en interne toegangstrukture die belangrikste is. In hierdie artikel sal die status quo van toegangstrukture in huidige standaard vertalende woordeboeke met Afrikaans en Engels as behandelde taalpaar bespreek word. Voorstelle tot moontlike verbetering sal dan gemaak word.

By die bespreking van die eksterne toegangstruktuur word daar voorgestel dat die eksterne sneltoegangstruktuur verbeter word deur die gebruik van 'n eenvoudige duimindeks en dat die huidige stelsel van loopkoppe behou word. By die standaard eksteme toegangstruktuur word 'n meer deurdagte en beter gemotiveerde stelsel van homonimiese ordening, asook 'n meer konsekwente inisieel-alfabetiese ordening voorgestel.

Die fokus by die bespreking van die interne toegangstruktuur val op die verbetering van die interne sneltoegangstruktuur deur middel van 'n vernuwende gebruik van tipografiese en nietipografiese struktuurmerkers. Verbeterde ordeningstelsels binne inligtingskategorieë word voorgestel as 'n vernuwing in die standaard interne toegangstruktuur.

Breë riglyne word dus gegee om woordeboektoeganklikheid te verbeter en gebruikersvriendelikheid te verhoog deur verbeterde toegangstrukture.

Sleutelwoorde: EKSTERNE SNELTOEGANGSTRUKTUUR, EKSTERNE SOEKROETE, EKSTERNE TOEGANGSTRUKTUUR, GEBRUIKERSVRIENDELIKHEID, HOMONIMIE, INTERNE SNELTOEGANGSTRUKTUUR, INTERNE SOEKROETE, INTERNE TOEGANGSTRUKTUUR, LEKSIKOGRAFIE, METALEKSIKOGRAFIE, POLISEMIE, STANDAARD EKSTERNE TOEGANGSTRUKTUUR, STANDAARD INTERNE TOEGANGSTRUKTUUR, STANDAARD VERTALENDE WOORDEBOEK, STRUKTUURMERKER, TOEGANGSTRUKTUUR, WOORDEBOEK, WOORDEBOEKTOEGANKLIKHEID

The access structure is the primary guide structure in any standard translation dictionary's central texts. The term "guide structures" refers to the set of structures identified in metalexicography that provides a framework within which the accessibility and availability of information types in the dictionary can be evaluated.

The access structure is, however, not a singular entity. It encompasses certain substructures, of which the outer and inner access structures are the most important. In this article the access structures in standard translation dictionaries with Afrikaans and English as treated language pair will be evaluated and suggestions will be made as to possible improvements. Tweetalige Woordeboek / Bilingual Dictionary (BD) and Groot Woordeboek / Major Dictionary (MD), two desk dictionaries, will be taken as representative of this class in the absense of a true standard dictionary. The conception of a new standard translation dictionary will be advocated. The outer access structure will be discussed first. 


\section{The outer access structure}

\subsection{The outer search path}

User-friendliness is one of the most important focus points in current metalexicography. Ways in which the lexicographer can help the user to decode information more easily and quickly are therefore emphasized. On a structural level, changes can be made to access structures to ensure that they act as more effective guides to the user on his/her search paths to the desired information. To guide the user along the outer search path (that is the search up to the desired lemma), there should be a well-defined, easily understandable outer access structure.

The current outer access structures in bidirectional standard translation dictionaries with Afrikaans and English as treated language pair are not entirely successful. A new standard translation dictionary should note the successes, but address the failures by employing new, creative methods. A discussion of this necessary innovation requires smaller subdivisions of the outer access structure. A distinction may be made between the rapid outer access structure and the standard outer access structure.

\subsection{The rapid outer access structure}

The need to take the user to the lemma as quickly as possible requires a strictly pragmatic approach from the lexicographer. For example, this approach requires an initial alphabetical listing of lemmata. An elementary thumb index indicating the start of each alphabetical unit in both central texts of the bidirectional dictionary may improve the accessibility of the initial alphabetical listing. The thumb index is a part of the rapid outer access structure that is not used in either $\mathrm{BD}$ or MD, but could be employed in a new dictionary. The financial costs of such an innovation should, however, be kept in mind. If the additional costs alienate any part of the target user group, this system should be reconsidered.

Other vital elements of the rapid outer access structure should be employed on the search path from the start of an alphabetical unit to the lemma, namely running heads (Hausmann and Wiegand 1989: 338). These words indicate the first and last lemmata to be found on each page. The user's knowledge of alphabetical listing is relied upon. Users must be able to gauge immediately if the lemma they require can be found on the relevant page. The next step of the search can only begin thereafter.

The system of running heads is one of the few user-friendly guide systems that both BD and MD use consistently. Running heads are unfortunately the beginning and end of the rapid outer access structure in these dictionaries. In most other dictionaries the rapid outer access structure also ends here. Yet the Japanese dictionary makers, Kenkyusha, have created a marker of the rapid 
outer access structure that stretches to the lemma. Typographical innovation is combined with different colour printing in their Lighthouse series. The frequency of use of a lemma is indicated by means of a changing number of asterisks that are given as structural markers to the left of the lemma sign. These structural markers are supplemented by giving the most frequently used words in red print. For a more comprehensive discussion see Gouws (1996: 21).

A similar system is employed in the monolingual Collins COBUILD English Language Dictionary to show frequency of use of different lemmata. Here a grouping of blackened and empty diamonds in the margin to the right of the lemma shows its relative frequency of use. Each word that appears in their comprehensive corpus (The Bank of English) is marked by a band of 5 diamonds. The number of diamonds that are blackened denote the frequency of the lemma. Dozen, for example, is marked by four black diamonds showing that it is used far more frequently than dragoon which is marked by only one black diamond. These elements give rapid access to the lemmata and therefore provide help on the rapid outer search path. This is especially helpful when trying to build up a core vocabulary in a second or foreign language.

The Lighthouse and COBUILD series may be primarily aimed at the learner's market, but these innovations should be considered while setting up a new standard translation dictionary. The Reader's Digest Afrikaans-Engelse Woordeboek / English-Afrikaans Dictionary (henceforth RD) has already broken the South African mould by employing different colours of print, but with less success than the Lighthouse series. Structural markers in colours other than black, as well as structural markers such as COBUILD's can play an important role in the South African dictionary market in future, if lexicographers are prepared to change the status quo with regard to the rapid outer access structures of their dictionaries. Financial costs and the availability of suitable corpora will however play decisive roles.

\subsection{The standard outer access structure}

The rapid outer access structure provides rapid access along several parts of the user's outer search path. It may even lead right up to the lemma sign as is the case in the Lighthouse English-Japanese Dictionary and Collins COBUILD English Language Dictionary. Yet it cannot guide the user along the last, most vital part of the outer search path. The final choice of the desired macrostructural element is made by means of the standard outer access structure. This is also the case in BD and MD.

Both these dictionaries are monoaccessible. This implies that the standard outer access structure corresponds to the macrostructure in each part of the dictionary. This is not the case in $\mathrm{RD}$, where a group of texts called "Words in action / Woorde in aksie" is presented in the margins. Louw and Gouws (1996) show that these style and usage notes form a separate macrostructure in each central text of the dictionary, thereby making the dictionary polyaccessible. 
Tweetalige Aanleerderswoordeboek / Bilingual Learner's Dictionary (henceforth BLD) includes similar notes, but these are inserted as inner texts in the conventional macrostructures. See for example the treatment of flu.

\section{flu griep Griep is ' $n$ siekse was ' $n$ mens gerooonlik in die winter kry. Flu is an illness which one usually gets in winter. \\ $\square$ flu nown (no plural) \\ flu is an abbreviated, informal word for influenza}

It is advisable that BLD's example should currently be followed in South Africa, and that a standard translation dictionary should remain monoaccessible in each alphabetical macrostructure.

Initial alphabetical standard outer access structures are the norm in BD and MD. As far as possible, sublemmata are niched and not nested, thereby not disturbing the alphabetical listing. Nested sublemmata are semantically ideal, but currently niched sublemmata is the only plausible option. Haas's (1967) basic desideratum, that the best dictionary is one in which users find the required information in the first place they look, forms the foundation for this lexicographic practice.

Haas's point is also relevant to another important aspect of the standard outer access structure, viz. the order of homonyms. The markers denoting different homonyms are accepted as elements of the standard outer access structure. The underlying system by which these homonymous lemmata are put in order must however also be accepted as part of the standard outer access structure. The user who knows which system is used and how this system is implemented in a dictionary has a shortened search path.

A practical example of this is ordering using the principle of frequency of use. A mother-tongue speaker or good second language speaker who has a well-developed linguistic intuition and has read the user's guide, can unlock the desired information faster than others. The lexicographer may expect that users search for answers to their queries in the user's guide.

The user's guide interacts with the access structures to improve the dictionary's user-friendliness. BD and MD do not follow this norm of user-friendliness. Firstly, there does not seem to be an ordering system of homonyms according to frequency of use. Secondly, their user's guides do not provide any explanation for their system of ordering and of semantic relations such as homonymy and polysemy. Without a good guide this aspect of the dictionary's outer access structure loses almost all its value. The problem is even more pressing in the case of the inner access structure.

An example of the successful integration of the user's guide with innovation in the outer and inner access structures of a dictionary is the monolingual Cambridge International Dictionary of English (henceforth CIDE). CIDE gives an 
interesting alternative to the prototypical marking of homonymy on the level of the standard outer access structure. Just to the right of the lemma guide words are given in rectangular frames. These guide words are usually a single key word or phrase taken from the lemma's definiens. They are intended to help the user to make an immediate choice of the correct lemma.

CIDE's splitting approach has unfortunately led to a situation where the basic semantic difference between homonymy and polysemy is denied, but a large measure of communicative value is maintained by the strength of these guide words as elements of the access structure, as is illustrated by the treatment of par.

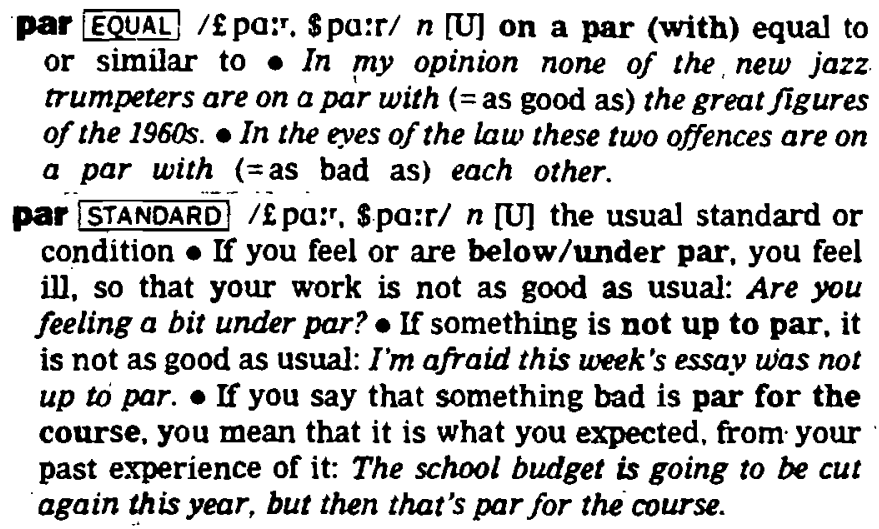

The fact that this system is explained simply and effectively to the target user (who is obviously not a linguist) in both the preface and user's guides is further evidence of CIDE's user-orientated åpproach.

The use of guide words as formal elements of the standard outer access structure of the dictionary can add an important dimension to a standard translation dictionary. The lexicographer will however have to decide what manner of addressing the user these entries should have and therefore in what language they should be presented. Be it in English or in Afrikaans, the success of this system will depend on a consistent application and thorough explanation in the user's guide. These crucial principles also hold true for the inner access structure.

\section{The inner access structure}

\subsection{The inner search path}

The inner access structure has as its main goal to, as Gouws (1996: 19) puts it, "help the user to reach the specific information categories within the article". The complexity of the microstructure and the number of information categories 
that it encompasses necessarily make the user's inner search path more difficult. A good inner access structure must employ structural markers to lead the user on this inner search path. These markers are mostly either foreign markers or markers known to users, but used outside of their normal context. The creative use of already known markers confuse users by unnecessarily increasing the dictionary's textual condensation. Interaction between the inner access structure and the user's guide is here of the utmost importance. Hausmann and Wiegand (1989: 338) state that "most metatexts explain the inner access structure". This is however not the case in the canonical South African translation dictionaries.

\subsection{The rapid inner access structure}

$\mathrm{BD}$ and MD continuously ignore elementary principles of user-friendliness. Structural markers are encoded in the dictionary, but the users are expected to decode these markers without the necessary help. The problem can also lie on the other side of the scale. Information can be provided, but without clear structural markers to guide the user to that specific information category.

In both $\mathrm{BD}$ and $\mathrm{MD}$ a workable inner access structure and especially a rapid inner access structure is lacking. A lack of structural markers can lead to a frustrating and unsuccessful simulated question and answer dialogue between the lexicographer and the user. In any new standard translation dictionary, structural markers as elements of the rapid inner access structure will determine the success of the user's inner search path.

\subsubsection{Structural markers}

Gouws (1996: 23) defines the role of structural markers as follows: "Structural markers ... indicate the borders between information categories as well as the position and scope of different search areas." This premise leaves enough room to broaden the scope of the term "structural marker" to include the elements of the access structure that indicate semantic relations.

A new system of structural markers should for example be employed to indicate different equivalents for different senses of the lemma, as opposed to different equivalents for different usages of the lemma or other partially synonymous translation equivalents. A system based on the numerical and letter systems used in monolingual dictionaries should replace the confusing system of semicolons and commas currently used in BD and MD. If some of the old methods are integrated with the new approach, structural markers that function as indicators can help to provide rapid access to the correct equivalent. A good system of indication will have to be combined with consistently applied sense and equivalent discrimination. The user's guide will also have to explain every structural marker used. 
There are more conventional structural markers that form part of the rapid inner access structure. These fall into two main categories, viz. non-typographical and typographical structural markers.

Non-typographical structural markers are special markers such as frames, coloured blocks and diamonds that introduce separate information categories. Despite BD and MD's lack of these vital markers there are some precedents in South African practical lexicography. Gouws (1996: 23-25), for example, focuses on two.

BLD employs a coloured diamond to distinguish collocations from other examples within the broader category of examples. These collocations obtain the status of separate treatment units and should therefore be made as accessible as possible. They can create further problems in that they can have their own translations that are in no way related to the equivalents given for the lemma or sense of the lemma. See for example the treatment of due to as a collocation in BLD. The translation "te danke aan" bears no relation to "aankom" that is given for the lemma due. Collocations are mostly complex independent entities that require separate treatment from example sentences that have the lemma and/or the translation equivalent as address. It is therefore imperative that a structural marker with unique reference be used to provide rapid access to this information category.

Information categories other than collocations should also be introduced by structural markers. The most prominent of these is grammatical information. Gouws (1996) refers specifically to the Verklarende Handwoordeboek van die Afrikaanse Taal (HAT) that uses an empty quadrangular frame to mark different parts of speech in which the lemma can function. A similar system is also employed in BLD.

These markers are valuable because they give rapid access to information on parts of speech. Yet they can only be effective if the user actually understands the system. When non-typographical markers are used, it is important that there is good interaction between the rapid inner access structure and the user's guide of a specific dictionary. The function of each of the structural markers should be explained simply and carefully.

The rapid inner access structure should also interact with the key element of the microstructure, viz. semantic information. The role of markers for semantic relations has already been discussed, but there is another information subcategory that needs structural markers. This subcategory is semantic and contextual guidance in the form of sense and equivalent discrimination. As a non-typographical structural marker, CIDE's guide word in a frame can be used to denote sense discrimination. This means that the form (e.g. the frame) of CIDE's guide words can be transformed into an element of the rapid inner access structure that gives rapid access to the explanation of each sense which in turn gives access to the correct translation equivalent. This marker should combine with a numerical marker indicating source language polysemy to create an effective marker of the rapid inner access structure. The frame depends 
on the number to prevent a confusing system such as the one that is found in CIDE.

The value of non-typographical structural markers with semantic and contextual guidance is not limited to sense discrimination. Equivalent discrimination can also form a separate information subcategory and should be introduced by a non-typographical structural marker. Both BD and MD have context or co-text words or phrases that act as equivalent discrimination either for different equivalents for different senses of the lemma or within target language synonym paradigms. See for example the treatment of stuk in MD.

\section{stuk, (-ke), piece (of bread); fragment, chip (of glass); _ chunk (of lead); play (stage)}

These words or phrases are in the target language, have the translation equivalent as address and usually appear in the article position directly after the equivalent. In both $\mathrm{BD}$ and MD they are placed in brackets, which act as structural markers that give rapid access to the information. Other information categories in MD are also placed in brackets. Brackets could also function in their normal syntactic use in some of the example sentences. They can therefore lose their value as unique structural markers.

Any new systems of contextual and semantic guidance should interact with structural markers with unique reference to avoid confusing the user. Typographical structural markers should be used in addition to the non-typographical markers. Different font types and sizes, bold print, capital letters and italics can all be used to aid fast and effective identification of a specific information type. Once again these markers have to be explained thoroughly in the user's guide. The lexicographer has to be careful in the choice and application of the chosen markers, because too many foreign, complex markers can increase the textual condensation unnecessarily and make the dictionary less user-friendly.

$\mathrm{BD}$ and $\mathrm{MD}$ do use some effective structural markers such as the typographical marking of examples and the presentation in capital letters or bold type of a key word in each of these examples. Unfortunately too little is done to establish truly effective systems of structural markers and accordingly truly effective rapid inner access structures.

\subsection{The standard inner access structure}

The standard inner access structure should share in the spirit of innovation. Methods of microstructural ordering should be determined empirically by 
means of questionnaires, interviews, etc. that form part of dictionary planning. This will ensure that the ordering of senses and synonyms that suit the target user best will be employed. These systems should then be applied consistently in the dictionary.

It is not only ordering in information subcategories though that is relevant, but also ordering in the dictionary article as a whole. At this point the standard inner access structure overlaps with the article structure. The choices made as to the utilization of certain article positions should be carefully planned and well-motivated in the user's guide.

\section{Conclusion}

Should the inner access structure be an effective guide in the search for among others help with pronunciation, communicative equivalence and pragmatic contextualisation, the dictionary will certainly be employed optimally as text and as text-type carrier. If this inner access structure is combined with an effective, transparent outer access structure a high standard of user-friendliness and dictionary accessibility can be set. Sadly, neither BD nor MD has reached this point.

Bilingual dictionaries are of pivotal importance in South Africa. They need to bridge cultural and semantic gaps in our multicultural society. Yet this cannot be achieved if the users are frustrated in their efforts to find relevant information. Lessons should be learnt from the innovative approaches taken in the compilation of other dictionaries.

\section{Bibliography}

\section{A. Dictionaries}

Bosman, D.B. et al. 1984". Tweetalige Woordeboek / Bilingual Dictionary. Cape Town: Tafelberg.

Du Plessis, M. 1993. Tweetalige Aanleerderswoordeboek / Bilingual Leamer's Dictionary. Cape Town: Tafelberg.

Grobbelaar, P. (Ed.). 1987. Reader's Digest Afrikaans-Engelse Woordeboek / English-Afrikaans Dictionary. Cape Town: The Reader's Digest Association.

Kritzinger, M.S.B. et al. $1986^{13}$. Groot Woordeboek / Major Dictionary. Pretoria: J.L. van Schaik.

Odendal, F.F. 1994. Verklarende Handwoordeboek van die Afrikaanse Taal. Doomfontein: Perskor.

Procter, P. et al. (Eds.). 1995. Cambridge International Dictionary of English. Cambridge: Cambridge International Press.

Sinclair, J. et al. (Eds.). 1995. Collins COBUILD English Language Dictionary. London: HarperCollins.

Takebayashi, S. and Y. Kojima (Eds.). 1990. Kenkyusha's Lighthouse English-japanese Dictionary. Tokyo: Kenkyusha. 


\section{B. Other sources}

Gouws, R.H. 1996. Bilingual Dictionaries and Communicative Equivalence for a Multilingual Society. Lexikos 6: 14-31.

Haas, M. 1967. What Belongs in a Bilingual Dictionary? Householder, F.W. and Sol Saporta (Eds.). 1967: 45-50.

Hausmann, Franz J. and Herbert E. Wiegand. 1989. Component Parts and Structures of Monolingual Dictionaries. Hausmann et al. 1989-1991: 328-360.

Hausmann, Franz J., Oskar Reichmann, Herbert E. Wiegand and Ladislav Zgusta (Eds.). 1989 1991. Wörterbücher: Ein internationales Handbuch zur Lexikographie / Dictionaries: An International Encyclopedia of Lexicography / Dictionnaires: Encyclopédie internationale de lexicographie. Berlin: Walter de Gruyter.

Householder, F.W. and Sol Saporta (Eds.). 1967. Problems in Lexicography. Bloomington: Indiana University.

Louw, P.A. and R.H. Gouws. 1996. Lemmatiese en nielemmatiese adressering in Afrikaanse vertalende woordeboeke. South African Journal of Linguistics 14(3): 92-100, August 1996. 


\title{
Dictionaries and the Standardiza- tion of Spelling in Swahili*
}

\author{
James S. Mdee, Institute for Kiswahili Research, \\ University of Dar es Salaam, Tanzania
}

\begin{abstract}
The paper discusses the role of the dictionary in standardizing the spelling of Swahili. The discussion begins by defining key terms in this paper: spelling and standardization of spelling. It surveys lexicons written in Swahili between 1811-1990 and records the efforts made to establish spelling conventions for Swahili words in Roman characters, pointing out variant spellings of words written by different authors.

The paper focuses on the role played by different lexicons in setting orthography for Swahili words, viz. Steere (1870), Krapf (1882), Nettelbladt (1891), Madan (1903), Sacleux (1939), etc. It observes how the lexicons established norms for words of a language which was hitherto not written in Roman characters. It also shows how lexicons helped to standardize the spelling of words to its current form especially after a standard dialect had been selected, pointing out lexicons which exclusively recorded words of the standard language with minimal variants. Finally the paper emphasizes the significance of the dictionary to adhere to the standard orthography.
\end{abstract}

Keywords: STANDARDIZATION OF SPELLING, SPELLING CONVENTIONS, STANDARD ORTHOGRAPHY, SWAHILI ALPHABET, DIALECTICAL VARIATIONS, CATCHWORDS, PHONETIC TRANSCRIPTIONS, STANDARD LANGUAGE, SPELLING SYSTEM, NONSTANDARD ORTHOGRAPHY, STANDARDIZATION PROCESS, WORD-LIST, LEXICON AND DICTIONARY

Opsomming: Woordeboeke en die standaardisering van spelling in Swahili. In hierdie artikel word die rol van die woordeboek in die standaardisering van die spelling van Swahili bespreek. Die bespreking begin met die definiëring van sleutelterme in hierdie artikel: spelling en die standaardisering van spelling. Dit gee ' $n$ oorsig van leksikons wat tussen 1811-1990 in Swahili geskryf is en vermeld die pogings om spellingkonvensies vir Swahili woorde in Latynse letters vas te stel, terwyl spellinguariante van woorde deur verskillende outeurs uitgewys word.

Die artikel fokus op die rol wat deur verskillende leksikons gespeel is om die ortografie vir Swahiliwoorde vas te stel, nl. Steere (1870), Krapf (1882), Nettelbladt (1891), Madan (1903), Sacleux (1939), ens. Dit stel vas hoe die leksikons norme vir woorde van 'n taal wat tot op daardie tydstip nie in Latynse letters geskryf is nie, vasgestel het. Dit wys ook hoe leksikons gehelp het om die spelling van woorde in hulle huidige vorm te stand aard iseer, veral nadat ' $n$ standaarddialek gekies is, met vermelding van leksikons wat slegs woorde van die standaardtaal met min variante opge-

* This article is a revised version of a paper read at the Third International Conference of the African Association for Lexicography, held at the Potchefstroom University for C.H.E., Potchefstroom, 29-30 June 1998. 
teken het. Ten slotte beklemtoon die artikel die belangrikheid daarvan dat ' $n$ woordeboek by die standaardortografie bly.

Sleutelwoorde: STANDAARDISERING VAN SPELLING, SPELLINGKONVENSIES, STANDAARDORTOGRAFIE, SWAHILIALFABET, DIALEKTIESE VARIASIES, TREFWOORDE, FONETIESE TRANSKRIPSIES, STANDAARDTAAL, SPELLINGSISTEEM, NIESTANDAARDORTOGRAFIE, STANDAARDISERINGSPROSES, WOORDELYS, LEKSIKON EN WOORDEBOEK

\section{Introduction}

The observation by Krumm (1940: 3) that "the question of orthography of Swahili written in Roman characters is not yet definitely solved", is as valid today as it was more than half a century ago when it was made. Dictionaries compiled between 1882 and 1991 prove this fact despite the efforts made in 1925 by a Committee for the Standardization of Swahili (better known as the Chiponda Committee (see Mbaabu 1995)) and the Interterritorial Language Committee founded in 1930. The objective of this paper is to discuss the role of dictionaries in standardizing orthography of written Swahili in Roman characters. In this paper we shall (1) examine efforts made to establish spelling conventions in Swahili from the time when Swahili was first written in Roman script, (2) discuss the role of dictionaries in standardizing spelling of Swahili words from 1870 to 1990 , and (3) discuss why a dictionary should promote a standard orthography. But first of all let us briefly explicate what spelling and standardization of spelling mean.

Spelling, according to Gove (1961), is the art and technique of forming words by letters according to accepted usage or standard spelling as formulated by language planners. Standardization of spelling is concerned with unifying underlying linguistic diversity in order to make the standard language fit to be a national language. Standard orthography is the chosen spelling of a word out of the competing variants. This is the spelling that will be put into use in schools, government offices, the press and other areas. Standardization of a language has basically two steps: (1) creation of a model for imitation and (2) promotion of this model over rival models (Ray 1968). Having put into perspective what standardization of spelling means, we shall now examine how Swahili was introduced into writing systems.

\section{Writing Systems in Swahili}

Swahili! was already a written language in Arabic script in the 13th century (Eastman 1983: 21). For almost five centuries this script dominated Swahili writings which were mainly songs and poetry, e.g. the work of Fumo Liyongo, Aidarus bin Uthman, Binti Lembe, Mwengo bin Athuman, Muyaka Haji, etc. 
By the beginning of the 19th century, Roman script was introduced by European travellers and missionaries who visited East Africa and began to learn Swahili. They prepared Swahili word-lists, conversation books, grammar books, teaching manuals and dictionaries. In this paper we shall confine our discussions to spelling conventions in Roman script because it has a considerable literature from which we can draw examples for illustration. Let us now look at how Swahili was first written in Roman characters.

\section{Transcription of Swahili in Roman Characters}

When a hitherto unwritten language is chosen as a standard language, a spelling system is developed for it and conventions are set up on how it is to be written (Eastman 1983). First attempts to establish orthography of Swahili words were made by European visitors, explorers and adventurers between 1811-1849. This involved (1) the transcription of Swahili phones in order to determine the Swahili phonetic alphabet and (2) establish spelling conventions for Swahili words as in Table I below, with examples taken from Whiteley (1969: 50ff):

Table I Early Swahili Word-lists in Roman Script

\begin{tabular}{|c|c|c|c|c|}
\hline English & $\begin{array}{l}\text { Smee } \\
(1811-12)\end{array}$ & $\begin{array}{l}\text { Ross and } \\
\text { Brown } \\
(1843)\end{array}$ & $\begin{array}{l}\text { Gullain and } \\
\text { Vignard } \\
(1846-48)\end{array}$ & $\begin{array}{l}\text { Burton } \\
(1845-49)\end{array}$ \\
\hline fire & moto & - & moto & moto \\
\hline house & - & youm ba & nioum ba & nyumba \\
\hline fish & summakee & soo-ma-ke & soumaki & somba \\
\hline wind & paepo & - & phepo & - \\
\hline cow & gnombai & - & $m$ gom be & ngombe \\
\hline smoke & - & mo-she & mouchi & - \\
\hline sun & toowar & - & djou & juwa \\
\hline firewood & - & cooney & kouni & - \\
\hline oil & - & $m a-f o o-t a$ & mafouta & - \\
\hline teeth & - & ma-no & mino & menu \\
\hline die & $k o o f a$ & - & koukoufa & - \\
\hline
\end{tabular}

Orthography of most of the words in Table I differs from the current spelling of the same words because the authors used the phonetic alphabet of their native languages to establish spelling of Swahili words. From the data given above it is obvious Ross and Brown, and Burton, and perhaps also Smee, were Englishmen, and Guillain and Vignard were Frenchmen. We shall therefore have to refer to English and French when discussing how the authors' languages influ- 
enced Swahili orthography. Let us first look at the vowels. Swahili has five open vowels $a, e, i, o$ and $u$, but our data shows the same vowels being used to represent different phonological values. The early word-lists show that the English $a$ which is sometimes pronounced as /e/ was used to represent the Swahili vowel $e$ as we see in Ross and Brown's list, e.g. mano instead of meno. The same applies to the English $e$ (pronounced as $/ \mathrm{i} /$ ) which is used to represent the Swahili vowel $i$, e.g. moshe (instead of moshi) or $m$-we-ve (instead of mwivi), and oo (pronounced as $/ \mathrm{u} /$ ) which is used to represent $u$, e.g. mafoota (instead of mafuta). In the same list we see the consonant $c$ used for $/ \mathrm{k} /$, a common feature in English also, e.g. cattle [kætl] and kettle [ketl], hence kuni was transcribed as cooney and $m k u k i$ as $m^{\prime} c o o-k e$. Other influences of the authors' languages can be observed in Gullain and Vignard who write the Swahili $u$ as the French ou, e.g. kouni (instead of kuni), koufa (instead of kufa) and mafouta (instead of mafuta). Likewise $j$ was written as the French $d j$, e.g. djou for jua.

\section{Swahili Alphabet}

The alphabet used for writing Swahili is the same as the international Roman alphabet, with letters chosen to represent the Swahili phones. It also uses digraphs i.e. a sequence of two letters to represent single sounds. According to Steere (1870) the Swahili alphabet has five vowels: $a, e, i, 0$ and $u$, and sixteen consonants: $b, c h, d, f, g, h, j, k, l, m, n, p, r, s, t, v, w, y$ and $z$. The vowels are pronounced as in Italian, and the consonants as in English. He also included the following digraphs:
$g h$ is pronounced as the Dutch $g$,
$k h$ is pronounced as the German ch,
th is pronounced as the English th in thing,
$k w$ is pronounced as the English qu in queer,
ny has the sound of French ni or English ni as in companion,
$n g^{\prime}$ resembles English $n g$ when it occurs at the end of a word, e.g. bang,
king, etc.,
$n g$ resembles English $n g$ as in engage, and
sh resembles the English sh.

Steere also notes the emphatic feature in the plosive $k$ : khabari, kheri etc. Krapf (1882), another pioneer of written Swahili, also recorded five vowels like Steere, and twenty consonants: $b, c h, d, d z, f, g, g h, g n, h, j, k, l, m, n, p, q, r, s, s h, t, t h, v$, $w, y$ and $z$. Krapf adds $d z, g n$ and $q$, which are lacking in Steere. The alphabet as used in written Swahili today owes much to Steere. It has both single letters and digraphs : $a, b, c h, d, d h, e, f, g, h, i, j, k, l, m, m b, n, n d, n g, n g^{\prime}, n j, n y, o, p, r, s$, $s h, t, t h, u, v, w, y$ and $z$. 


\section{Efforts to set up Spelling Conventions for Swahili}

An examination of Swahili texts and lexicons written after the second half of the 19th century until the first half of the 20th century shows efforts made by some Swahili linguists to set up spelling conventions for Swahili words. Serious attempts were made by Steere (1870), Krapf (1882), Illaire (1890), Nettelbladt (1891), Velten (1903), Madan (1903) Sacleux (1939) Seidel (1941), etc. In Table II below we present a sample of lexical items from some of these lexicons and then discuss important developments in setting the spelling for Swahili.

\section{Table II Spelling of Words in Swahili Lexicons 1870-1939}

\begin{tabular}{|c|c|c|c|c|c|}
\hline $\begin{array}{l}\text { Steere } \\
(1870)\end{array}$ & $\begin{array}{l}\text { Krapf } \\
(1882)\end{array}$ & $\begin{array}{l}\text { Nettelbladt } \\
\text { (1891) }\end{array}$ & $\begin{array}{l}\text { Madan } \\
(1903)\end{array}$ & $\begin{array}{l}\text { Sacleux } \\
\text { (1939) }\end{array}$ & $\begin{array}{l}\text { Current } \\
\text { Spelling }\end{array}$ \\
\hline afathali & afathali & afasali & afathali & $\begin{array}{l}\text { afazali/ } \\
\text { afuzali/ } \\
\text { afzali }\end{array}$ & afadhali \\
\hline $\begin{array}{l}\text { afya } \\
\text { assubuil }\end{array}$ & $\begin{array}{l}\text { afialafya } \\
\text { assubukhil }\end{array}$ & afia & $\begin{array}{l}\text { afialafya } \\
\text { assubuhil }\end{array}$ & afya & $\begin{array}{l}\text { afya } \\
\text { asubuhi }\end{array}$ \\
\hline ussubui & $\begin{array}{l}\text { ussubukhi/ } \\
\text { essubukhi }\end{array}$ & ussubui & $\begin{array}{l}\text { subuhi/ } \\
\text { ussubui }\end{array}$ & usubuhi & \\
\hline athuuri & - & asuuri & athuuri & $\begin{array}{l}\text { azuhuri/ } \\
\text { aduhuri }\end{array}$ & adhuhuri \\
\hline burre & burre & bure & burre & bure & bure \\
\hline chosha & chosha & tchoscha & chosha & čša & chosha \\
\hline
\end{tabular}

Compare also the spelling of words in other lexicons and their current orthography in brackets: In Velten (1903), muungu (mungu), maradi (maradhi), qabla (kabla), tawalli (tawala), qissa (kisa), radi (radhi), afadali (afadhali), zayidi (zaidi), assubuhi (asubuhi), el-jumaa (ijumaa), barza (baraza), chinsha (chinja), billa (bila), and in Seidel (1941), mudda (muda), fezza (fedha), ruddisha (rudisha), waqati (wakati), qasirika (kasirika), sogo (soko), gora (jora), boonde (bonde), qoodi (kodi), nakhoda (nahodha).

\section{Influence of Foreign Languages on Swahili Orthography}

A critical examination of the data in Table II shows (1) variant spellings for the same words and (2) variant representations of a phoneme. Variants of a word reflect the existence of more than one dialect in use in one speech community: Cf. (1) afadali, afadhali, afasali, afathali, afazali and afzali, or (2) asubuhi, assubui, assubukhi, essubukhi, subuhi, ussubui, ussubukhi, etc. The variants cannot be said to belong to the various Swahili dialects because they are loanwords. In this 
case we are obliged to concur with Krumm's point of view (Krumm 1940: 50ff.) that the different Arabic variants we see in these word-lists originated from different Arabic dialects whose speakers came to East Africa and introduced them in Swahili:

It seems natural that some Arabian words have penetrated into Swahili not in their classical but in their dialectic or foreign form ... Often we find in Swahili besides the usual form of the Arabic or Persian word a dialect form, for instance, dhaifu and daifu; dhoruba, doruba and zoruba; rejea and regea, jambia and gambia - which prove that these words have found their way into Swahili from different Arabian sources.

However, we should also note that some of the variants are creations of the authors whose languages influenced the spelling of the words. For example, the German $\beta$ or ss which is pronounced as /s/ may have influenced German authors to use a double $s$ instead of a single $s$ which is pronounced as $/ z /$. Thus in order to articulate kisa correctly, they wrote the word with a double s, i.e. qissa. One could also argue that afasali in Nettelbladt's list was his creation to suit his German Swahili learners so that they could pronounce [afazali]. We note the same for all Nettelbladt's words with s, e.g. asuuri for azuuri. The influence of foreign languages as a source of variants in Swahili is also seen in $j$ or $d j$ pronounced as /d3/ in French as in ngoja, ngodja. We observe the same for ch and sh each of which has three variant representations of the same phoneme: $c h, \mathcal{C}$ and $t c h$ (French) for $/ \mathrm{t}[/$, e.g. cheka, ceka and tcheka, and sh, $s$ and sch (German) for $/ \mathrm{J} /$, e.g. ishirini, iširini and ischirini.

Another influence of foreign languages on Swahili as evident in early writings is the double consonance in Arabic which has phonological and semantic signification in that language but has no bearing on Swahili. For example:

katala he killed
kattala he caused to kill
alima he knew
allama he caused to know
salim he was well
sallam he made or wished somebody to be well

The double consonant in kattala above has caused the meaning to change and differ from that of katala. Phonologically a double consonant in Arabic signifies an emphatic consonant. These features are not found in Swahili. Unfortunately they have been introduced in Swahili. For example: 
tena and tenna

mwalimu and mwallimu

tayari and tayyari

feza and fezza

\section{Vowel Harmonization of Loanwords}

Swahili syllables are open and their structure is basically $C+V$. Some Arabic words adopted in Swahili consist of group consonants (which are not double consonants) and lack the $\mathrm{C}+\mathrm{V}$ structure. For example:

bakhti, barza, arbain, ashrini, hutba, etc.

These words were entered in some of the early lexicons and also appear in some Swahili literature from this time. However, in course of time the group consonants were separated by vowels whose selection was based on the rules of vowel assimilation by the same vowel that precedes the consonant (progressive assimilation) or by the same vowel that follows the consonant (retrogressive assimilation). For example:

Progressive assimilation

bahti $>$ bahati

barza $>$ baraza

$k$ ufli $>$ kufuli

hutba $>$ hutuba

ahdi $>$ ahadi

kahwa $>$ kahawa

wakti $>$ wakati

bikra > bikira

Retrogressive assimilation

kadri $>$ kadiri

akli $>$ akili

ashrini > ashirini

Sometimes a vowel inserted is chosen in relation to the place of articulation of the preceding consonant, especially bilabials and dentolabials. For example:

arbaini $>$ arubaini

kibri $>$ kiburi

nafs $>$ nafusi

The voiceless plosive velar in Arabic words is pronounced with an emphatic $/ \mathrm{h} /$ sound, hence represented as kh. Many Swahili words of Arabic origin with 
the voiceless plosive velar have always retained the /h/ sound especially among Swahilis under Arabic influence. We find words with the voiceless velar $k$ with emphatic $h>k h$ in many of the early Swahili books and lexicons. For example:

khabari, khadaa, kheri, khofu, khutuba, nakhota, alkhamissi, bakhti, assubukhi, etc.

But because the emphatic sound had no semantic signification and was articulated by Swahilis under Arabic influence only, it was later assimilated, and the stop dropped, hence leaving $h$ to represent $k h$. For example:

\section{khabari > habari \\ khadaa $>$ hadaa \\ khofu $>$ hofu \\ khutuba > hutuba}

When lexicons were compiled during this time, Swahili had no standard dialect to which to refer for the standard spelling of words. Consequently, the compilers of these lexicons recorded every sound they heard, because it represented a lexical item. Sometimes they could not give a good transcription of the words pronounced for them either because they failed to capture the sounds correctly, or because their resource persons failed to articulate the words clearly. Cf. youmba (instead of nyumba), or che-mo-je, mouya, moya (instead of moja).

\section{Creation of a Model to Follow}

So far we have seen the beginning of writing Swahili in Roman characters and noted the reasons for variant spellings of the same words. Efforts were therefore made to standardize the language and hence harmonize the spelling of its words. In 1925 an education conference attended by members from Tanganyika and Zanzibar was held at Dar es Salaam and the Zanzibar dialect was selected as Standard Swahili for the two dependencies. Among other things it also proposed how to standardize the spelling of Swahili words. It gave a list of words which had variant spellings and recommended the standard orthography to be adopted (Mbaabu 1995: 47). For example:

$\begin{array}{ll}\text { Standard } & \text { Nonstandard } \\ \text { dhoruba } & \text { dharuba } \\ \text { heshima } & \text { hishima } \\ \text { hekima } & \text { hikima } \\ \text { ishirini } & \text { asharini } \\ \text { lakini } & \text { ilakini }\end{array}$


After the Dar es Salaam meeting, an Interterritorial Conference attended by members from Kenya, Tanganyika, Uganda and Zanzibar was held in June 1928 at Mombasa, and the Dar es Salaam recommendations were endorsed. Swahili orthography as a model to follow was therefore set in 1925 and endorsed in 1928. Two years later, in 1930, an Interterritorial Language Committee was founded and was given the responsibility to ensure that the standard orthography was upheld. The objective of the committee was among other things to standardize the orthography of Swahili words, as Sheikh Amri Abedi, Minister for Justice to the Republic of Tanganyika, rightly recapitulated it at the Annual Meeting of the East African Language Committee on 30 September 1963:

Your committee came into being on 1st January 1930. Its terms of reference were to standardize the orthography and the grammar of the Swahili language, to write a new standard dictionary and to scrutinize the books in use in schools and to certify that they conformed with the standards laid down.

A new dictionary was necessary because the dictionaries which were already compiled had not aimed at standardizing the language. This is why each had a different orthography for the same words. For example:

assubui, assubuhi, assubukhi, as-subuhi, ussubui, usubukhi, usubuhi, subuhi and asubuhi

nakhotha, nakhoza, nakhoda, nahoza and nahodha

This was understandable because their objective was to record Swahili words as used by its speakers and/or as they perceived them to be the representation of the Swahili sounds. A new dictionary would have corrected this. Dictionaries which were compiled under the supervision of or certified by the Language Committee were those by F. Johnson: Swahili-Swahili Dictionary (1935) and Swahili-English Dictionary (1939). The following is a sample of catchwords from these two dictionaries:

adhana, afadhali, afya, ahera, asantelahsante, asubuhi, bara, basi, huba, abedari etc. (Johnson 1935)

adhana, afadhali, afya, ahera, asante, asubuhi, bara, basi/bas, huba, abedari/ habedari (Johnson 1939)

The new dictionaries attempted to standardize the language. (1) The double consonant feature which was dominant in many loanwords was abandoned. Cf. bara, basi, huba, asubuhi etc. in Johnson (1935 and 1939) on the one hand and Steere (1870), Krapf (1882) and Velten (1910) on the other. (2) One variant was selected out of the competing ones and was adopted as the standard orthogra- 
phy except if it was felt that more than one form had wide usage. Dialectal forms were reduced substantially but not eliminated completely, as shown in Table III below:

Table III Catchwords with Variant Orthography in Swahili Lexicons (1870-1939) for the Letter A

$\begin{array}{lllll}\text { Steere } & \text { Krapf } & \text { Velten } & \text { Johnson } & \text { Johnson } \\ (1870) & (1882) & (1910) & (1935) & (1939)\end{array}$

Number of catchwords

Number of catchwords with variants

Number of variants in $\%$

Lexicons compiled before Swahili was standardized have more variants than those written thereafter. This explains why Johnson (1935) with 293 catchwords had only $1 \%$ while Velten with 265 catchwords had $16 \%$ with variant spelling. Unfortunately Johnson (1939) increased the number of catchwords with variant spelling which undermines the notion of standardizing orthography, especially so because both these dictionaries by Johnson were compiled at about the same time, with the same number of catchwords (293 vs 281 ) and the same objectives.

\section{Contribution of Swahili Lexicons towards the Standardization of Swahili Orthography}

The first Swahili lexicons, though fragmented, were compiled between 1811 and 1848 (see Whiteley 1967: 50). By the time the Zanzibar dialect (Kiunguja) was selected as Standard Swahili in 1928, Swahili had ten lexicons: Steere (1870), Detrieux (1880), Krapf (1882), Delaunay (1888), Seidal (1890), Nettelbladt (1891), Büttner (1890), Velten (1910), Madan (1903) and Brutel (1928). Coincidentally all except Krapf (1882) were in Kiunguja, the dialect which later became Standard Swahili. Krapf was aware of Kiunguja and entered some words from this dialect and marked them. Despite the discrepancies we noted above, e.g. double consonants and superfluous variants, the lexicons laid a good foundation for the standardization of Swahili. One of the criteria used to 
select a language or dialect to be a standard language is the availability of published literary works, grammar and lexicons in that language. Kiunguja had all these. The lexicons greatly influenced the standardization of spelling because the language planners could use them to select the forms with a higher degree of occurrence and simple spelling i.e. without double consonant or aspiration. Therefore, although it is agreed that the pre-Johnson dictionaries did not endeavour to standardize Swahili and that their contents reflected that fact, they laid the base for the standardization process to take place. Let us now examine the role of the dictionary in standardizing orthography.

\section{The Role of the Dictionary in Standardizing Orthography}

A dictionary whose objective is to describe the standard dialect has to record the standard orthography of a lexical item where there are competing forms (Mdee 1990). A lexicographer should therefore decide which form is considered standard and which is not. In this regard a standard dictionary has only one mission: to propagate the standard orthography.

A dictionary is regarded as the authority on spelling, grammar, meaning and usage of a language. It records the standard orthography of the norm, and if it includes items of another norm or other dialects of the same language, the social and geographical areas where each is spoken, are marked accordingly. A dictionary shall command authority over its users if it convinces them that it is adhering to the standard. Otherwise it will lose credibility as an authoritative reference of the standard language.

We have seen how the standard dictionaries compiled by the Interterritorial Language Committee (Johnson 1935 and 1939) attempted to standardize orthography of Standard Swahili. It was therefore expected that subsequent compilers of Swahili dictionaries would adhere to the standard. In what follows we shall examine dictionaries compiled between 1960 and 1990, namely Rechenbach (1968), TUKI (1981) and Feeley (1990), i.e. thirty years after Swahili had been standardized. Rechenbach is a 641 page dictionary with 401 catchwords under letter A, TUKI, a dictionary of 325 pages, has 528 catchwords under letter A, and Feeley with its 179 pages has 298 catchwords under letter A. All three dictionaries describe Standard Swahili and owe much to their predecessors, especially to Johnson (1935 and 1939). Above we noted the double consonant and variant spellings as main features found in pre-Johnson dictionaries. Johnson (1935) eliminated both of these. The post-Johnson dictionaries adhered to the noninclusion of double consonants in Swahili words but not to the exclusion of variant forms. As can be seen from Table IV, Rechenbach (1968) has 77 catchwords with variant spellings out of 401 catchwords under letter A, while TUKI (1981) has 53 words with variant spellings out of 528 and Feeley (1990) 5 words out of 298 catchwords under letter A. 
Table IV Catchwords with Variant Spellings in post-Johnson Dictionaries (1968-1990) for the Letter A

$\begin{array}{lll}\text { Rechenbach } & \text { TUKI } & \text { Feeley } \\ (1968) & (1981) & (1990)\end{array}$

Number of

401

528

298

catchwords

Number of

77

53

5

catchwords

with variants

Number of

19

10

2

variants in \%

Rechenbach (1968) has the highest number of variant forms, higher even than the pre-Johnson dictionaries as was shown in Table III. The author adopted a retrogressive approach to dictionary making by recording every plausible variant that Swahili speakers could form. Rechenbach was not interested in continuing the process of standardizing Swahili started by Johnson (1935). TUKI's $10 \%$ is equally large for a dictionary of Standard Swahili. Feeley's number is acceptable if one bears in mind that in any language there are some words with variant spellings which are all accepted as standard. Rechenbach and TUKI picked most of the variants from the pre-Johnson dictionaries which Johnson (1935) had dropped in his effort to standardize Swahili. Both of them undermined the role of the dictionary in standardizing a language and eroded the whole concept of Standard Swahili as Table V below shows.

Table V Variant Spellings in Rechenbach (1968) and TUKI (1981)

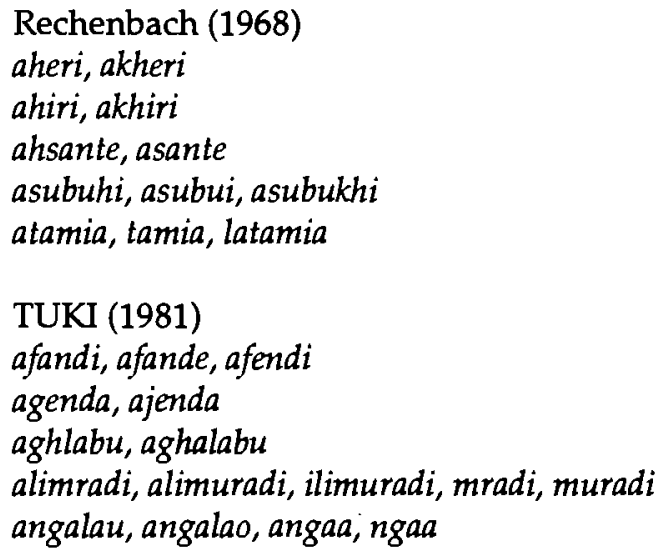


The above sample upholds Krumm's observation made in 1940 and quoted in the introduction of this paper: "The question of the orthography of Swahili written in Roman characters is not yet definitely solved." It shows the following: (1) Both dictionaries seem undecided on what is more accepted and widely used (i.e. the standard form) to such an extent that every sound is recorded. See atamia and asubuhi in Rechenbach (1968), and angalau and alimradi in TUKI (1981). (2) Both of them record a loanword in two forms: (a) as it is pronounced in the source language and (b) as it is written in and adapted to the Swahili alphabet. Cf. eksidenti and aksidenti; ateri and arteri; ajenda and agenda. (3) Both dictionaries record Arabic loanwords first as they are pronounced in Arabic (with group consonant or aspirated $k h$ ), and then adapt it according to the syllabic law of Bantu languages, i.e. a consonant is always followed by a vowel. Cf. akrabu, akarabu; abwabu, abuwabu; aghlabu, aghalabu; arbaini, arubaini etc. and the deletion of the aspiration and the stop $/ \mathrm{k} /$, e.g. akhera, ahera; akheri, aheri etc.

\section{Relevance and Realities of the Decisions of the Interterritorial Con- ference of 1928}

The adoption of the Zanzibar dialect as Standard Swahili for East Africa and all the resolutions of the Dar es Salaam Conference implied that the Mombasa dialect (Kimvita), which had already literary works written in it, would be confined to spoken and informal communication. In literary works it was to be abandoned in favour of the standard dialect. It was for this reason that the East African Literature Bureau was established in order to publish Swahili works which had been certified by the Interterritorial Language Committee as written in Standard Swahili. However, some writers continued writing literature in Kimvita and as a result of this, dialectal forms continued to find their way in both literary works and dictionaries. This seems to explain why Johnson (1939) failed to adhere to the standard orthography as he attempted in his previous dictionary (Johnson 1935). Consequently he recorded more variants, as can be seen from Table III above which shows that $10 \%$ of the catchwords under letter $A$ in Johnson (1939) were variants in contrast with Johnson (1935) which had only $1 \%$. Likewise, the editors of TUKI (1981) who endeavoured to compile a standard Swahili dictionary, Kamusi ya Kiswahili Sanifu, recorded 10\% dialectal forms.

In essence, the Chiponda Committee created words that did not exist when it selected forms of the standard dialect which were alien to speakers of other dialects. For example: asili (instead of asli), ishirini (ashirini), tisini (tisaini), sheria (sharia), lakini (ilakini), hasa (haswa) etc. Since the later spelling was preferred to Swahili under Arabic influence, the former were resisted in favour of the latter.

Dialectal variations are still generated in Swahili, even for words which entered the language in recent years. Cf. ateri and arteri, eproni and aproni, edita 
and editori, pension and pencheni, hospitali and spitali etc. The variants reflect different sections of the speech community using the different forms. The essence of these variants is that the loanwords are adopted in two different ways, namely as they are pronounced e.g. edita, eproni, ateri, pensheni, etc. and as they are written in their original language with some adjustments to conform to Swahili structure, e.g. editori (from the English word editor), aproni (apron), arteri (artery), hospitali (hospital) etc. There is also the problem that the loanwords are not pronounced correctly. For example, pencheni (pension) or spitali (hospital).

Indeed one could argue that we are not yet to see the end of dialectal words in Swahili dictionaries because many of these are found in contemporary literature read in schools. Cf. A. Abdala's Sauti ya Dhiki, or A. Nassir's Malenga wa Mvita. All these show that the exercise of standardizing orthography is an ongoing process and lexicographers and writers have to be active participants in promoting the standard.

\section{What dictionaries should do to promote the Standard Orthography}

We noted in the introduction that a standard language is a medium of communication in government administration, education, the press and all forums where a degree of formal communication is needed. In order to ensure that communication is not hampered, a standard language and indeed the standard orthography have to be adopted and consistently used so that it can spread within and even without the speech community. Standardization of a language is an arbitrary decision made by language planners (1) to choose a language or dialect of a language as the norm, (2) to simplify spelling of words of the norm and (3) to adopt one form where a word has variant forms, and popularize it.

For the dictionary to be able to execute this responsibility, it is recommended that lexicographers should record only the form that is considered to be standard or accepted by the majority of the Swahili speakers. It is however possible for a dictionary to include words of other social and regional dialects provided that (1) it states that objective unambiguously, and (2) it marks geographical and social status of the dialectal words. Contrary to this, the dictionary would confuse and mislead the users, and would be condemned by the readers and the reviewers. This is what befell Gove and his dictionary, Webster's Third New International Dictionary of the English Language in 1961 when the critics called the dictionary "a calamity, an exponent of anarchy in language and a disaster" (Lodwig and Barrett 1967: 56). The readers and reviewers criticized the dictionary because according to them it failed in its responsibility to set forth and maintain standards of usage for the language.

Such criticisms could be made against Rechenbach (1968) and TUKI (1981) because of the superfluous variant spellings of catchwords. See Tables IV and $V$. It is important for dictionaries to adhere to the standard language and what 
is considered to be the most accepted spellings of words because it has a role of standardizing, disseminating and teaching the norm.

\section{Conclusion}

In this paper we endeavoured to examine the contribution of Swahili dictionaries in setting an orthography for Swahili words which culminated in standardizing the orthography of Standard Swahili. In doing so, we traced the beginnings of writing Swahili in Roman characters and noted (1) the variant spellings in different dictionaries, (2) the creation of the norm and (3) how the standard orthography was realized. Finally we examined the role of the Swahili dictionaries over the last 100 years in setting Standard Swahili and standard orthography and why it is important for dictionaries to uphold standard orthography.

\section{Reference Works}

Abedi, A., Sheikh. 1964. Speech at the Annual Meeting of the East African Language Committee 30 September 1963. Swahili 34(1): 5-8.

Eastman, Carol M. 1983. Language Planning: An Introduction. San Francisco: Chandler and Sharp. Fishman, Joshua A. (Ed.). 1968. Readings in the Sociology of Language. The Hague / Paris: Mouton. Kiango, J.G. (Ed.). 1995. Dhima ya Kamusi katika Kusanifisha Lugha (The Role of a Dictionary in Standardizing Language). Dar es Salaam: TUKI / UDSM.

Krumm, B. 1940. Words of Oriental Origin in Swahili. London: Sheldon Press.

Lodwig, R. and E. Barrett. 1967. The Dictionary and the Language. New York: Hyden Book Co.

Mbaabu, Ireri. 1995. Dhima ya Kamusi katika Kufundisha na Kujifunza Kiswahili (The Role of a Dictionary in Teaching and Learning Swahili). Kiango, J.G. (Ed.). 1995: 47-59.

Mdee, J.S. 1990. Theories and Methods of Lexicography in the Standard Swahili Dictionary. Unpublished Ph.D. thesis. Leipzig. University of Leipzig.

Ray, Punya Sloka. 1968. Language Standardization. Fishman, Joshua A. (Ed.). 1968: 754-765.

Seidel, August. 1890. Praktische Grammatik der Suaheli-sprache. Vienna: A. Hartleben.

Velten, C. 1905. Desturi za Wasuaheli na Khabari za Desturi za Sheria za Wasuaheli (Swahili Traditions and Customary Laws of the Swahili). Göttingen: Vandenhoek und Ruprecht.

Whiteley, W.H. 1969. Swahili: The Rise of a National Language. London: Methuen.

\section{Cited Dictionaries}

Brutel, E. 1928. Vocabulaire français-kiswahili et kiswahili-français. Paris: Pere Blancs.

Büttner, Carl Gotthilf. 1890. Wörterbuch der Suaheli Sprache, Suaheli-Deutsch und Deutsch-Suaheli. Stuttgart: Spemann.

Delaunay: 1885. Dictionnaire français-kiswahili. Paris: Pere Blancs.

Dutrieux, D. 1880. Dictionnaire français-kiswahili. Bruxelles: Association Intemationale Africaine. 
Gove, P.B. (Ed. in Chief). 1961. Webster's Third New International Dictionary of the English Language. London: G. Bell/Springfield, Mass.: G. \& C. Merriam.

Feeley, G. 1990. Swahili-English Dictionary. MS-tryk Denmark.

Illaire, Walter von Saint Paul. 1890. Suaheli Handbuch. Stuttgart: Spemann.

Johnson, F. 1935. Kamusi ya Kiswahili, yaani Kitabu cha Maneno ya Kiswahili (Swahili Dictionary, i.e. a Swahili Wordbook). London: Sheldon Press.

Johnson, F. 1939. A Standard Swahili-English Dictionary. Nairobi/Dar es Salaam: Oxford University Press.

Krapf, L.A. 1882. Swahili-English Dictionary. London: Trubner and Co.

Madan, A.C. 1903. Swahili-English Dictionary. London: Oxford University Press.

Nettelbladt, F. 1891. Suaheli-Drogoman: Gespräch, Wörterbuch und praktische Anleitung zum Verkehr mit den Eingeborenen in Deutsch-Ost-Afrika. Leipzig: F.A. Brockhaus.

Rechenbach, Charles W. et al. 1968. Swahili-English Dictionary. Washington, D.C.: The Catholic University of America Press.

Sacleux, Charles. 1939. Dictionnaire Swahili-Français. Paris: Institut d'Ethnologie.

Seidel, M. 1941. Suaheli Konversations Grammatik. Heidelberg: Julius Groos.

Steere, Edward. 1870. A Handbook of the Swahili Language as Spoken at Zanzibar. London: Society for Promoting Christian Knowledge.

Taasisi ya Uchunguzi wa Kiswahili. 1981. Kamusi ya Kiswahili Sanifu (Dictionary of Standard Swahili). Nairobi/Dar es Salaam: Oxford University Press.

Velten, C. 1910. Suaheli-Wörterbuch 1. Teil: Suaheli-Deutsch. Berlin: Reimer. 


\title{
Kriteria vir 'n Afrikaanse aanleerderwoordeboek*
}

\section{Anna Nel Otto, Departement Afrikaans, Universiteit Vista, Port Elizabeth, Republiek van Suid-Afrika, Suid-Afrika}

\begin{abstract}
Criteria for an Afrikaans learner's dictionary. This article determines the theoretical and practical criteria for an Afrikaans learner's dictionary. The target users of this dictionary is black tertiary students for whom Afrikaans is a second or third language. Such a dictionary should be directed at the needs of the target users, i.e. be a suitable medium for both decoding and encoding. The compilation of the learner's dictionary should chiefly be based upon real language use. This entails a thorough data collection which should contain adequate detail and is presented systematically. The selected information should be understandable and easily retrievable. The dictionary should have an explanatory section. The recording of macrostructural elements should be linguistically motivated. The recording of specific macrostructural elements should be based on the needs of the target users and insights of the lexicographer with regard to interlingual aspects. As far as the microstructure is concerned, adequate pronunciation, grammatical, semantic and usage guidance should be provided.
\end{abstract}

Keywords: CRITERIA, LEARNER'S DICTIONARY, TARGET USER, DECODING, ENCODING, EXPLANATORY SECTION, PRONUNCIATION GUIDANCE, GRAMMATICAL GUIDANCE, SEMANTIC GUIDANCE, USAGE GUIDANCE

Opsomming: Hierdie artikel bepaal die teoretiese en praktiese kriteria vir ' $n$ Afrikaanse aanleerderwoordeboek. Die teikengebruikers van hierdie aanleerderwoordeboek is swart tersiêre studente, vir wie Afrikaans 'n tweede of derde taal is. So 'n woordeboek moet op dié teikengebruikers se behoeftes afgestem wees, d.w.s. 'n geskikte medium vir sowel dekodering as enkodering wees. Die woordeboek moet hoofsaaklik gebaseer wees op werklike taalgebruik. Dit behels 'n deeglike materiaalversameling wat voldoende detail bevat en sistematies aangebied word. Die geselekteerde gegewens moet op sodanige wyse verwerk word dat dit maklik ontsluit en verstaan kan word. Die woordeboek moet ' $n$ toeligtingsgedeelte bevat. Die seleksie van makrostruktuurelemente moet linguisties gemotiveer wees. Die seleksie van spesifieke makrostruktuurelemente moet op grond van die teikengebruikers se behoeftes en die leksikograaf se insigte met betrekking tot interlinguale aspekte gebaseer wees. Wat die mikrostruktuur betref, moet voldoende uitspraakleiding, grammatiese leiding, semantiese leiding en gebruiksleiding verskaf word.

* Hierdie artikel is ' $n$ verwerking van die slothoofstuk van 'n D.Litt.-verhandeling Kriteria vir in Afrikaanse aanleerderwoordeboek wat in 1989 deur die Universiteit van Stellenbosch aanvaar is. 
Sleutelwoorde: KRITERIA, AANLEERDERWOORDEBOEK, TEIKENGEBRUIKER, DEKODERING, ENKODERING, TÓELIGTINGSGEDEELTE, UITSPRAAKLEIDING, GRAMMATIESE LEIDING, SEMANTIESE LEIDING, GEBRUIKSLEIDING

\section{Inleidend}

Dit gaan in hierdie artikel om die vasstelling en beskrywing van kriteria vir die opstel van 'n aanleerderwoordeboek vir niemoedertaalsprekers wat swart tersiêre studente is. Die ontwerp van hierdie kriteria is moontlik gemaak deur die navorsing in ' $n$ verhandeling om die linguistiese kriteria van hierdie besondere soort woordeboek aan die lig te bring (vgl. Otto 1989).

\section{Kriteria}

\subsection{Doel}

Die teikengebruikers moet duidelik vasgestel wees en die aanleerderwoordeboek moet op hulle behoeftes afgestem wees. Die teikengroep vir hierdie studie is swart tersiêre studente wat hul kommunikatiewe vaardighede in Afrikaans wil verbeter.

Die funksie van die woordeboek moet duidelik vasgestel en deurgaans in aanmerking geneem word. ' $n$ Aanleerderwoordeboek is gerig op die verbetering van 'n niemoedertaalspreker se kommunikatiewe vermoë. Hierdie eis wat aan die aanleerderwoordeboek gestel word, is nie ' $n$ lukraak eis nie, maar vind aansluiting by ' $n$ bepaalde teoreties gemotiveerde siening van wat taal is (vgl. bv. Webb 1983: 233), word deur taalonderwysers aanbeveel (vgl. bv. Richards en Schmidt 1983: vii), word in leksikografiese publikasies onderskryf (vgl. bv. Hartmann 1983: 158), en word deur aanleerders self vereis (vgl. die antwoorde op vraelys 1 in Otto 1989).

Ten einde reg te laat geskied aan laasgenoemde eis, behoort die aanleerderwoordeboek 'n geskikte element vir sowel dekodering as enkodering te wees. In ' $n$ aanleerderwoordeboek kan 'n mens slegs vir dekodering suggereer dat a vervangbaar is met $b$. Ten aansien van enkodering moet die gebruiker nie net weet dat $a=b$ nie, maar ook dat $a=b$ indien voorwaardes $c$, $d$ en e nagekom word. Aanleerderwoordeboeke verskaf hierdie ekstra inligting op verskillende maniere, bv. deur etikette, sintaktiese kodes, gebruiksnotas en veral voorbeelde. Maingay en Rundell (1987: 131) beklemtoon die waarde van voorbeelde, en beginselbesluite oor die doeltreffendste wyses waarop al die relevante inligting van 'n bepaalde lemma aangebied word, deur 'n omvattende analise van aanleerders se foute te maak (Maingay en Rundell 1987: 133-135). Moulin (1987: 105 e.v.) verskaf nuttige wenke oor hoe die aanleerderwoordeboek benut kan word by enkoderende take (vgl. ook Harvey en Yuill 1997 oor ' $n$ bespreking van Collins COBUILD English Language Dictionary se rol 
by geskrewe (enkoderende) take). Die aanleerderwoordeboek kan verder bydra tot die ontwikkeling van leksikale vermoë (vgl. o.a. Tomaszczyk 1987: 141 e.v. en Béjoint 1987: 102) mits die definisies duidelik, presies en volledig geskryf is (vgl. Jain 1981).

\subsection{Samestelling}

'n Deeglike materiaalversameling, hoofsaaklik gebaseer op werklike taalgebruik, moet gedoen word. Op grond van sy breë taalkennis mag die leksikograaf sy eie intuïsies gebruik, maar hy moet hom ook beroep op gesproke en geskrewe bronne. Taalkundige studies en bestaande woordeboeke moet met omsigtigheid hanteer word, aangesien hierdie sekondêre bronne onjuisthede kan bevat (Geeraerts en Janssens 1982: 27-28).

Die materiaal moet deeglik verwerk word sodat dit voldoende detail bevat en moet sistematies aangebied word. Daar moet nagegaan word volgens watter kriteria die makro- en mikrostruktuur van 'n woordeboek gekies gaan word. Indien mens weet watter leksikale items (makrostruktuur) en inligting oor hierdie woorde (mikrostruktuur) die leksikograaf wou selekteer, kan die sukses van verwerking hieraan gemeet word. Afgesien van die kriteria vir die verskillende inligtingstipes moet mens jouself ook afvra hoe gedetailleerd die gegewens is en hoe sistematies dit aangebied word. ' $n$ Vergelyking met soortgelyke woordeboeke bied 'n goeie aanknopingspunt ten einde sodanige vrae te kan beantwoord (Geeraerts en Janssens 1982: 28-29).

Die geselekteerde gegewens moet op sodanige wyse verwerk word dat dit maklik ontsluit en verstaan kan word (Geeraerts en Janssens 1982: 29). 'n Volledige toeligtingsgedeelte en die onderrig van woordeboekgebruiksvaardighede is dus ook onontbeerlik. Strevens (1987: 78 e.v.) wys egter daarop dat slegs die mees professionele niemoedertaalonderwysers die toeligtingsgedeelte lees en ook net sommige van hulle. Vir baie onderwysers en byna al die aanleerders bly die potensiële hulp wat in aanleerderwoordeboeke beskikbaar is, onbekend. Die fout lê nie noodwendig by die onderwysers nie. Die uitgewers is ook vasgevang in ' $n$ dilemma: hoe meer inligting hulle in die aanleerderwoordeboek plaas, hoe komplekser word hulle kodifikasie en hoe minder kan 'n aanleerder dit sonder leiding verstaan. Underhill (1985: 103) sê: "It is the teacher's responsibility to teach students how to use the MLD (monolingual learner's dictionary) effectively." 'n Gebruikersvriendelike woordeboek sal nietemin rekening hou met die naslaanvaardighede van die teikengebruikers (vgl. Gouws 1996: 175-176).

\subsection{Toeligtingsgedeelte}

Die toeligtingsgedeelte moet sodanig saamgestel word dat dit die volgende essensiële inligting bevat: 
- die doel van die woordeboek,

- die wyse waarop die woordeboek saamgestel is,

- die omvang van die woordeboek,

- die inligtingstipes wat voorsien word,

- inligting oor die klanksisteem van die taal:

- 'n sistematiese aanbieding van foneme en allofone,

- 'n uitspraakgids, en

- 'n uitspraaksleutel met enkele woorde as voorbeelde vir elke simbool,

- inligting oor grammatika:

- 'n minigrammatika wat inligting oor o.a. woordsoorte, fleksie en afleiding bevat,

- inligting oor die wyse waarop semantiese leiding aangebied word,

- inligting oor die wyse waarop gebruiksleiding aangebied word,

- spellingleiding,

- lyste wat onreëlmatige vorme bevat, bv. deelwoorde,

- afkortings,

- SI-eenhede en hul veelvoude, en

- $\quad$ 'n gids tot die gebruik van afkortings, leksikografiese konvensies en tegnieke.

\subsection{Makrostruktuur}

Die opname van makrostruktuurelemente moet linguisties gemotiveer wees sodat elemente met leksikale-itemstatus as lemmas optree (vgl. Ponelis 1989).

Die opname van spesifieke makrostruktuurelemente moet op die teikengebruikers se behoeftes en die leksikograaf se insigte met betrekking tot interlinguale aspekte gebaseer wees. In 'n aanleerderwoordeboek behoort funksionele faktore ' $n$ belangrike rol te speel, gevolglik is daar deur middel van 'n vraelys vasgestel watter bronne of situasies, bv. die woordeskat in hul voorgeskrewe boeke en studiehandleidings, en watter tipes woorde, bv. moeilike afleidings en samestellings, vir studente belangrik is; verder is gekyk na die tipes aktiwiteite waarvoor studente die woordeboek sal wil gebruik, bv. om Afrikaanse boeke te lees. In plaas van 'n statistiese benadering tot die vasstelling van die woordeskat (vgl. Ickler 1982 wat dit as misleidend en periferaal beoordeel) word 'n behoeftegerigte benadering voorgestel. Kontrastiewe analise (vgl. o.a. Van Els e.a. 1984: 38) en fouteanalise (vgl. Nickel 1972: 11-15) kan vrugbaar in die leksikografie gebruik word. (Vgl. ook Van Roey 1988: 161-165.)

\subsection{Mikrostruktuur}

\subsubsection{Uitspraakleiding}

Voldoende uitspraakleiding moet verskaf word om korrekte uitspraak te verseker. 
Uitspraakleiding moet op 'n waarnemingsbasis berus, d.w.s. daar moet objektief nagegaan word hoe mense woorde uitspreek (vgl. Read 1982: 87). In in aanleerderwoordeboek behoort standaarduitspraak as uitgangspunt geneem te word (vgl. De Villiers en Ponelis 1987: 43-44 se uiteensetting van standaarduitspraak). Indien daar variasie binne standaarduitspraak voorkom, behoort erkenning aan die belangrikste uitspraakvariante gegee te word (vgl. bv. die noordelike [æ] teenoor die suidelike $[\varepsilon]$ ).

Uitspraakleiding moet deur middel van fonetiese transkripsies by elke lemma verskaf word (vgl. Malone 1967: 115, Landau 1984: 93 en Wells 1985: 49). Dit is egter noodsaaklik dat studente onderrig moet word in die gebruik van fonetiese tekens, anders sal hierdie stelsel as gebruikersonvriendelik beskou en dalk selfs glad nie verstaan word nie.

Die transkipsiesisteem moet eenvoudig, volledig, sistematies en akkuraat wees. Die IPA-stelsel voldoen aan hierdie vereistes.

Lettergreepverdeling en sillabeverdeling moet afsonderlik en korrek aangedui word. Woorde kan op twee wyses sinvol verdeel word: ten opsigte van ' $n$ ortografiese weergawe kan 'n aanduiding gegee word van die skeiding van woorddele by skryf en ten opsigte van die getranskribeerde vorm kan sillabeverdeling voorsien word. Indien hierdie onderskeid nie duidelik is nie, kan die gebruiker verwar word (vgl. Gouws 1984: 293-294).

Die resultate van klankprosesse soos ontstemming, nasaalassimilasie en vokaalverandering as gevolg van klemverskuiwing moet aangedui word (vgl. Gouws 1984: 297). Een van die weinige aanleerderwoordeboeke wat wel aandag skenk aan hierdie aangeleentheid, is Collins COBUILD English Language Dictionary wat die boskrif $o$ gebruik om die moontlike weglating van vokale aan te dui. Hierdie woordeboek onderskei tussen beskermde vokale (waarvan die uitspraak onveranderd bly) en onbeskermde vokale (waarvan die uitspraak kan wissel). Oor variasie in hierdie woordeboek sê Brazil (1987: 162) o.a. die volgende:

In devising a way of representing variation in the dictionary, a compromise has to be reached between being faithful to observable fact and cluttering up the typographical representation so that the average user will find it unusable. The simplest method seemed to be to use superscripts for all those segments where considerable variation is to be found.

Die hoofklem en sekondêre klem moet aangedui word. Klem word in die praktyk op verskillende wyses in aanleerderwoordeboeke aangedui. Oxford $A d-$ vanced Learner's Dictionary of Current English, Longman Dictionary of Contemporary English en Chambers Universal Learners' Dictionary dui bv. hoofklem aan deur die teken (') voor die sillabe wat dit voorafgaan te plaas, terwyl sekondêre klem deur die teken (,) voor die beklemtoonde sillabe aangedui word. Collins 
COBUILD English Language Dictionary gebruik 'n besonder nuttige stelsel waarvolgens beklemtoonde vokale donkerder gedruk en ook onderstreep word.

Die foneme van die taal en hul allofone moet in die toeligtingsgedeelte opgeneem word (Al-Kasimi 1977: 109-110). Die leksikograaf wat bv. ' $n$ aanleerderwoordeboek vir 'n swart teikengroep wil opstel, sal 'n kontrastiewe analise van die twee betrokke tale se foneeminventarisse en allofone moet maak ten einde vas te stel watter klanke verwarring by die aanleerder kan veroorsaak.

In die toeligtingsgedeelte moet daar ' $n$ uitspraakgids wees wat uitspraakleiding verskaf en ' $n$ uitspraaksleutel waarin enkele bekende woorde as voorbeelde vir elke simbool optree (Al-Kasimi 1977: 109-110).

\subsubsection{Grammatiese leiding}

Grammatiese leiding moet sodanig wees dat aanleerders in staat gestel kan word om selfstandig korrekte sinne te genereer. Ten einde gestand te doen aan hierdie eis moet die aanleerderwoordeboek, volgens Jackson (1985: 54), vier tipes grammatiese inligting verskaf. Die eerste drie tipes verteenwoordig eksplisiete inligting. Eerstens is daar inligting oor die wyse waarop 'n leksikale item verbuig kan word, veral wanneer dit nie afleibaar is uit die algemene reëls van die grammatika nie. Tweedens is daar woordsoortaanduiding. Derdens kan meer spesifieke eksplisiete sintaktiese inligting gegee word, bv. werkwoorde wat geklassifiseer word as oorganklik en onoorganklik. Die vierde tipe hou verband met implisiete grammatiese inligting wat onregstreeks met behulp van goed gekose voorbeeldsinne in kollokasies aangebied word.

Daar moet verduidelikings in die toeligtingsgedeelte wees wat die sinvolle ontsluiting van grammatiese inligting in die woordeboek waarborg. Die inligting wat in die toeligtende aantekeninge van ' $n$ woordeboek weergegee word, is tweeledig van aard. 'n Deel van dié inligting het die sinvolle ontsluiting van die woordeboekartikels ten doel. Die ander deel van die inligting kom voor as 'n minigrammatika, d.w.s. 'n betroubare samevatting van die taal se grammatika (Gouws 1986: 29).

Die minigrammatika kan bv. op so 'n wyse by die grammatiese mikrostruktuurinligting geïntegreer word dat die woordeboekartikels 'n reeks kodes bevat wat in die minigrammatika geëkspliseer word. Volgens Gouws (1986: 30) is so ' $n$ aanbiedingswyse voordelig omdat dit ekonomie in die hand werk en die lemma se grammatiese kenmerke onmiddellik vir die gebruiker binne ' $n$ algemene patroon plaas. Die minigrammatika kan ook die vorm aanneem van 'n beknopte beskrywing van bepaalde grammatiese aspekte van die taal. So ' $n$ minigrammatika moet veral konsentreer op morfologiese en sintaktiese reëlmatighede (Gouws 1986: 30).

Daar moet kruisverwysings tussen die kodes in die woordeboekteksgedeelte en die minigrammatika wees. Dit sou 'n ideale situasie wees indien ' $n$ grammatikahandleiding en aanleerderwoordeboek wat op mekaar afgestem is, beskikbaar sou wees. Indien 'n grammatikahandleiding as hulpmiddel naas 'n 
aanleerderwoordeboek gebruik word, kan daar by die werkwoordlemma ' $n$ kruisverwysing na die bespreking van dié betrokke werkwoord in die grammatikahandleiding wees. In die toeligtingsgedeelte van die woordeboek kan die verskillende hooftipes werkwoorde en hulle kodes dan net baie kortliks verduidelik word. Waar sodanige grammatikahandleiding ontbreek, moet voldoende inligting in die toeligtingsgedeelte aangebied word en die gebruiker behoort deur middel van 'n kode na hierdie toeligtingsgedeelte verwys te word, indien die woordeboek 'n kodestelsel gebruik.

Woordsoortaanduiding moet eksplisiet wees. Volgens Bredemeier et al. (1977: 68) moet 'n woordeboekartikel so eksplisiet as moontlik wees en so min as moontlik op die taalintuisie van potensiële gebruikers afgestem wees. Sodra daar van die gebruiker verwag word om self afleidings te maak, bestaan die gevaar dat die gebruiker die verkeerde afleidings kan maak.

Woordsoorte moet voldoende gesubklassifiseer wees. Elke leksikale item moet duidelik geïdentifiseer word, d.w.s. tot watter klas en subklas dit behoort. Gleason (1967: 102) stel dit soos volg:

The dictionary should give for each item all pertinent grammatical identification. It is inadequate, particularly in a bilingual dictionary, merely to label items as noun or verb if it is known that there are significant subclasses within such classes. The dictionary should indeed index the grammatical statement.

Seleksiebeperkings moet, waar nodig, ten opsigte van die gebruik van selfstandige naamwoorde, adjektiewe en werkwoorde aangedui word. Die passiefkonstruksie word hier as voorbeeld uitgelig. Inligting oor die korrekte gebruik van die passiefkonstruksie behoort enersyds van 'n opvoedkundige grammatika verkry te word, bv. die reëls wat die passiefkonstruksie regeer, andersyds behoort die nodige leiding deur die woordeboek verskaf te word, aangesien die vraag na die moontlike toepassing van 'n passieftransformasie eerstens by die werkwoordklas berus en binne sekere klasse by die individuele werkwoord (vgl. Cowie 1987: 185 e.v.). By die lemmas van die niehandelingswerkwoorde, d.w.s. koppelwerkwoorde en werkwoorde soos hê en pas, behoort aangedui te word dat dié werkwoorde nie passiveerbaar is nie. Dit kan direk na die werkwoordkode of deur middel van 'n gebruiksnota aan die einde van die artikel aangedui word (vgl. verder Stein 1979 en Cowie en Mackin 1975: xxxviii vir ' $n$ bespreking van die hantering van seleksiebeperkings by die passiefkonstruksie).

Daar moet tussen verpligte en opsionele adjektiefkomplemente onderskei word. T. Herbst (1984: 6) beklemtoon die belangrikheid van die onderskeid tussen verpligte en opsionele komplemente en tussen komplemente en perifere elemente by adjektiewe: "It is of great importance for the foreign learner to be able to distinguish whether the constructions given for a word in the dictionary 
are merely possible uses of that word or whether the word must be used with a certain construction (at least in a certain meaning)."

Deeltjiewerkwoorde moet vasgestel word en van voldoende sintaktiese, semantiese en spellingleiding voorsien word om die korrekte gebruik daarvan te verseker. Die algemene reëls vir die plasing van die deeltjiewerkwoord behoort in die toeligtingsgedeelte uiteengesit te word. Genoeg voorbeelde behoort ook by die deeltjiewerkwoorde gegee te word, sodat die verskillende plasingsmoontlikhede van die deeltjiewerkwoord se komponente duidelik daaruit blyk. Die tipe hoofwerkwoord waaronder 'n bepaalde deeltjiewerkwoord kan ressorteer, behoort geïdentifiseer te word en uit die voorbeeldsinne te blyk. Deeltjiewerkwoorde word as saamgestelde eenhede alfabeties volgens die deeltjie in woordeboeke opgeneem. Die aanleerder word egter nie noodwendig met die deeltjiewerkwoord as eenheid gekonfronteer nie. In 'n aanleerderwoordeboek sou mens dit dus kon oorweeg om of 'n koppeltekenlemma (waar gepas) óf die deeltiliewerkwoord in omgekeerde orde en deur stippels verbind (bv. blaker ... uit sien uitblaker) op te neem. Die stippels is belangrik omdat die leksikale eenheid van die deeltjiewerkwoord daardeur aangetoon word. Die plasing van -ge- tussen die deeltjie en die werkwoordelike element in die verlede tyd behoort ook uitgewys te word. Spellingprobleme wat by nominalisering (bv. aanbeveel - aanbeveling) en voltooide deelwoorde (bv. inskryf - ingeskrewe) kan voorkom, behoort verder in ag geneem te word.

Daar moet sistematiese aanduidings van die verbindbaarheidsmoontlikhede van werkwoorde in die vorm van werkwoordpatrone gegee word. Vir Cowie (1983: 106) is die subklassifikasie van werkwoorde een van die noemenswaardige kenmerke van Idiomatic and Syntactic English Dictionary. Volgens hom het hierdie woordeboek drie belangrike kenmerke: (a) 'n gedetailleerde subklassifikasie wat geskep is deur oorganklikheid nie op 'n algemene wyse te hanteer nie, maar deurdat daar gekyk is na die verskillende tipes voorwerpe en komplementkonstruksies wat 'n werkwoord kan neem; (b) die sintaktiese funksies van werkwoorde is ten opsigte van elkeen van die betekenisonderskeidings aangedui; en (c) die patroonaanduidings by die inskrywings is deur 'n kodestelsel vervang.

Die volgende drie kriteria geld volgens T.H. Herbst (1984: 140-141) by die aanbieding van werkwoordpatrone:

- Is die uiteensetting van die patrone eenvoudig, duidelik, oorsigtelik en ondubbelsinnig?

- Is die inligting wat deur die patrone verskaf word, spesifiek genoeg om te verseker dat die woordeboekgebruiker in 'n posisie gestel word waar hy aanvaarbare sinne kan konstrueer en nieaanvaarbare sinne as sodanig kan herken?

- Is die lys kodes wat vir 'n bepaalde woord aangedui word volledig? (Volgens Lemmens en Wekker 1986: 14 moet die grammatiese kodes ondubbelsinnig wees en maklik gebruik kan word. Die kode moet inligting 
oor die grammatiese funksies, bv. direkte voorwerp, en die grammatiese kategorie, bv. naamwoordstuk, bevat.)

Elke werkwoordinskrywing en, waar gepas, elke subinskrywing moet van een of meer selfverklarende kodes voorsien wees. Dit sal 'n gids in die inleidende bladsye noodsaak om elementêre funksies en kategorie-etikette soos NS (naamwoordstuk) aan die gebruiker te verduidelik.

Die terminologie moet ooreenstem met die standaard moderne grammatikas van Afrikaans. In Afrikaanse woordeboeke word die gebruiker soms verwar deur huishoudelike afkortings. Wat terminologie betref, moet terme soos setsel en neweskikker wat in Ponelis (1979) gebruik word, ook in woordeboeke neerslag vind. Al die grammatiese patrone aangedui in elke werkwoordinskrywing of subinskrywing moet geillustreer wees deur voorbeeldsinne wat in dieselfde volgorde as die patrone gerangskik is. Dit vergemaklik die herwinning van inligting.

Transformasionele moontlikhede moet in inskrywings en, waar gepas, subinskrywings aangedui word. Indien passivering, verskuiwing van die indirekte voorwerp, e.s.m. moontlik is, moet hierdie transformasies in die inskrywings of subinskrywings aangedui word.

Kodes moet selfstandig, d.w.s. sonder hakies gebruik word.

Die inligting wat deur die patrone verskaf word, moet gebaseer wees op tipiese patrone sodat die enkodering daarvan natuurlike sinne tot gevolg sal hê (vgl. Sinclair 1987: 108).

Daar moet eksplisiete aanduidings ten opsigte van meervoude, verkleinwoorde, geslag, onreëlmatige verledetydsvorme, verboë vorme van adjektiewe, trappe van vergelyking en deelwoorde wees (vgl. Otto 1989: 145 e.v.).

Die algemene reëls wat ten opsigte van fleksie en afleiding geld, moet in die minigrammatika opgeneem word.

In die minigrammatika moet aangedui word hoe fleksie en afleiding in die woordeboek hanteer word, sodat die student uit hierdie inligting kan probeer aflei wat bv. die meervoudsvorm van 'n bepaalde leksikale item is indien die betrokke leksikale item nie in die woordeboek opgeneem is nie.

Daar moet kruisverwysings wees tussen fleksievorme wat alfabeties van mekaar verwyder is. By lank moet daar dus 'n verwysing na lang wees en by lang 'n verwysing na lank. By vorme soos lank en lang moet eksplisiet aangedui word binne watter kontekste elke vorm gebruik mag word.

By samestellings, afleidings, vaste uitdrukkings en idiome moet aangedui word of die onverboë of verboë vorm gebruik moet word (vgl. bv. Nasionale Woordeboek se hantering van hoog).

Linguisties gemotiveerde koppeltekenlemmas moet, waar nodig, opgeneem word (vgl. Gouws 1988a: 96).

Daar moet aangedui word of stamme voegseleisend of voegselverwerpend is (vgl. bv. verkeer in Nasionale Woordeboek). 
Alle prefikse en suffikse moet op hul alfabetiese plekke as lemmas opgeneem word (vgl. Stein 1985: 38 e.v.).

Die kategoriale funksies van elke affiks moet aangedui word ten opsigte van elke betekenisonderskeiding daarvan, d.w.s. die leksikograaf behoort aan te dui met watter woordsoorte ' $n$ spesifieke affiks kan kombineer (en met watter betekenis) en ook die grammatikale funksie(s) van daardie affiks spesifiseer.

Erkenning moet verleen word aan die morfologies-semantiese verbande wat tussen sommige woorde bestaan. So kan gelede woorde met dieselfde leksikale item as stam bv., naas hul opname op hul alfabetiese plek, in 'n afsonderlike kolom langs die artikel van die gemeenskaplike leksikale item verstrek word, bv. beken, erken, herken, verken, geken, e.s.m.

Samestellings en afleidings moet as lemmas opgeneem en verklaar word, aangesien dit moeilik sou wees om te bepaal watter samestellings en afleidings vir aanleerders deursigtig is en watter nie.

\subsubsection{Semantiese leiding}

Semantiese leiding moet gebaseer wees op 'n goeie teorie of teorieë. BallwegSchramm (1981: 462 e.v.) wys bv. op die praktiese nut van leksikale velde in die leksikografie.

Betekenis moet op linguistiese oorwegings gebaseer wees. Gouws (1987: 87) beklemtoon dat een van die leksikograaf se verpligtings teenoor sy gebruiker 'n duidelike onderskeid tussen leksikale betekenis en kontekstuele getuienis is.

Werklike tekste moet as datakorpus geneem word. Oor Collins COBUILD English Language Dictionary, wat op werklike tekste gebaseer is, sê Sinclair in die voorwoord van hierdie woordeboek die volgende:

With our textual evidence it is possible to be precise about the shape of phrases and the extent of their variation; the relative importance of different senses of a word; and the typical environment in which a word or phrase is used. Even when statements like this are already familiar, they are made with a different kind of authority in this book.

Daar moet tussen linguistiese betekenis en ensiklopediese inligting onderskei word om te verseker dat ensiklopediese inligting as 'n afsonderlike inligtingstipe in die woordeboek opgeneem word. Veral in 'n aanleerderwoordeboek sou' mens wel 'n geringe hoeveelheid saakbeskrywing kon toelaat om definisies duideliker te maak. Die saakbeskrywing moet egter altyd ondergeskik wees aan die betekenisbeskrywing (vgl. Ayto 1983: 98 wat die voorbeeld dog gebruik om dit te illustreer).

Die teikengebruikers en die aard van individuele woorde moet in aanmerking geneem word by die verklaringstegnieke. Volgens Wendland en Nida (1985: 12) is ' $n$ sosiosemiotiese benadering tot die vasstelling van die betekenis 
van die sg. "inhoudswoorde" die mees bevredigende benadering. Die sosiosemiotiese benadering behels die analisering van elemente van die verbale kode in terme van hulle sosiale agtergrond en gebruik. Hierteenoor vereis funksiewoorde 'n funksionele definisie aangevul deur baie voorbeelde (vgl. Kirkpatrick 1985: 11, asook Hanks 1979: 36 en 1987: 119 e.v. in hierdie verband).

Definisies moet opgeneem word wat aan die volgende kriteria voldoen (vgl. Zgusta 1971: 257-258):

- Alle woorde wat in ' $n$ definiens gebruik word, moet elders in die woordeboek verklaar word.

- Die lemma moet sodanig gedefinieer word dat dit betekenisverklarend optree.

- Sirkelvormigheid moet vermy word (vgl. ook Jain 1981: 277).

- Die struktuur en woordeskat van definisies moet eenvoudig wees (vgl. ook Jain 1981: 274, Stein 1979: 5 e.v., Kirkpatrick 1985, Whitcut 1978: 49, en Wekker en Hyams 1979: 411).

- Die definisies moet akkuraat en volledig wees (vgl. ook Whitcut 1978: 53).

Daar moet op grond van leksikologiese kriteria tussen polisemiese items en homonieme onderskei word (vgl. Lyons 1977: 21-22 vir kriteria).

Die rangskikking van betekenisonderskeidings moet gerig wees op die teikengebruikers, in die toeligtingsgedeelte verduidelik word en sistematies in die woordeboekartikels aangebied word. In Collins COBUILD English Language Dictionary is die rangskikkingsbeginsels (volgens frekwensie, sintaksis, kollokasionele of kontekstuele verbande en metaforiseringsprosesse - vgl. Moon 1987: 89 e.v.) dikwels in konflik met mekaar.

- Die betekenisonderskeidings van polisemiese woorde moet as duidelik gemerkte subinskrywings in die woordeboek opgeneem word (vgl. Cowie 1979: 85).

- Spesifieke kollokasies moet by die betekenisonderskeidings van polisemiese woorde aangebied word en beperkings op kollokeerbaarheid moet aangetoon word (vgl. Cowie 1979: 85).

- Daar moet aangetoon word watter afleidings ten opsigte van watter betekenisonderskeidings geld (vgl. Cowie 1979: 86).

Daar moet by polisemiese komposita aangedui word watter spesifieke betekenisonderskeidings ter sake is (vgl. Otto 1989: 262).

Semantiese relasies soos sinonimie, hiponimie en komplementariteit moet by betekenisonderskeidings betrek word (vgl. Cowie 1979: 87).

Ingeburgerde metafore (vgl. Otto 1989: 240) en gebruiklike idiome moet opgeneem en verklaar, en hul hantering in die toeligtingsgedeelte uiteengesit word (vgl. Nuccorini 1988). 


\subsubsection{Etimologiese leiding}

Ten opsigte van etimologiese leiding moet daar aangedui word aan watter taal of tale leenwoorde ontleen is (vgl. Otto 1989: 273).

\subsubsection{Gebruiksleiding}

Gebruiksleiding moet as ' $n$ afsonderlike mikrostruktuurelement aangebied word (vgl. Gouws 1988b: 42), moet gebaseer wees op die objektiewe waarneming van werklike gebruik (vgl. Wells 1973: 96), en moet sodanig wees dat dit die gebruiker ' $n$ aanduiding gee van die konteks en styl waarin elke woord of frase gepas is (vgl. Allen 1964': 272).

Voorbeeldmateriaal, d.w.s. verbale en nieverbale illustrasies moet in die woordeboek opgeneem word.

Voorbeeldsinne wat aan die volgende kriteria voldoen (vgl. Zgusta 1971: 263, Al-Kasimi 1977: 91, 96, Kirkpatrick 1985: 11-12, Fox 1987: 138-141, Mostert 1988: 156, Orszagh 1969: 219, en Drysdale 1987: 218-223), moet opgeneem word:

- Hulle moet funksioneel wees, d.w.s. hulle moet aantoon hoe 'n bepaalde woord in kombinasie met ander leksikale eenhede gebruik word.

- Hulle moet sistematies aangewend word, d.w.s. daar moet by elke betekenisonderskeiding van elke lemma ten minste een voorbeeldsin voorkom.

- Hulle moet informatiewe illustrasiemiddels wees, d.w.s. hulle moet werklik die gebruik van die woord illustreer en die gebruiker se begrip van die woord se grammatiese optrede, semantiese omvang en stilistiese kenmerke verbeter.

- Hulle moet natuurlik wees, d.w.s. welgevorm in ' $n$ teks.

- Hulle moet tipies wees, m.a.w. hulle moet aantoon hoe woorde werklik gebruik word.

- Hulle moet gebaseer wees op werklike taalgebruik, d.w.s. hulle moet uit 'n datakorpus geneem word.

- Hulle moet op die student se behoefte- en begripsvlak wees, m.a.w. hulle moet gekeur en geredigeer word ten gunste van die teikengebruiker.

- Alle voorbeelde moet volsinne wees.

Kollokasies wat aan die volgende kriteria voldoen (vgl. Cowie 1987: 132-136 en Benson 1985: 8-13), moet in die woordeboek opgeneem word:

- Kollokasies moet per linguistiese kriteria vasgestel word.

- Sowel grammatiese as leksikale kollokasies moet opgeneem word.

- Gevestigde en voorspelbare kollokasies moet duidelik deur middel van 'n konvensionele metode onder gebruikers se aandag gebring word. 
- Kollokasies wat semanties of situasioneel beperk is, moet aangedui word.

- $\quad$ 'n Oordeelkundige seleksie moet gemaak word van spesifieke items wat verteenwoordigend is van die totale reeks keuses by kollokasies wat met 'n "oop" stel items kan verbind.

- Verskillende semantiese subklasse by selfstandige naamwoorde (onderwerp, voorwerp) moet in kollokasies aangedui word.

Gebruikergerigte gebruiksnotas moet aangewend word waar addisionele inligting noodsaaklik is. Ten opsigte van enige inligtingstipe mag die leksikograaf dit nodig vind om bykomende inligting te gee. Hierdie aanvullende inligting kan per gebruiksnota hanteer word en dié gebruiksnotas word óf net na die bepaalde inligtingstipe óf aan die einde van die artikel verstrek. (Vgl. verder Otto 1989: 320-328.)

Etikette wat aan die volgende kriteria voldoen (vgl. veral Gouws 1988b: 450), moet opgeneem word:

- Die keuse van etikette moet gebaseer wees op kriteria wat uit die metaleksikografie kom.

Die etikette moet op die gebruiker se behoeftes afgestem wees.

- Die keuse van etikette moet sodanig wees dat dit daartoe kan bydra dat 'n gegewe lemma as lid van ' $n$ bepaalde deelversameling van die taal se woordeskat vasgestel word.

- Etikette moet sodanig gekies word dat hulle die een of ander afwyking van die standaardtaal merk.

- Die gebruik van etikette moet konsekwent toegepas word sodat korrekte gebruik verseker kan word.

- $\quad$ 'n Volledige verklaring moet gegęe word van elke etiket wat gebruik word en die verband van 'n bepaalde etiket met ander etikette moet duidelik aangetoon word.

- Etikette moet verstaanbaar wees.

- Stilistiese etikette moet gebruik word.

- Vaktaaletikette moet gebruik word by alle vakterme wat opgeneem is en in woordeboekartikels waar die lemma se polisemiese waardes sowel 'n algemene as 'n gespesialiseerde vaktaalgebruik insluit.

- Temporele etikette moet gebruik word by woorde wat van die standaardtaal afwyk op grond van hul chronolektiese gemerktheid.

- Mikrostruktuuretikette moet gebruik word om die leksikale inskrywingstipes te merk.

Nieverbale illustrasies (vgl. o.a. Landau 1984: 258-261 en Al-Kasimi 1977: 100) moet aangewend word wanneer ' $n$ bepaalde konsep beter daardeur verduidelik kan word as deur die verbale definisies, wanneer 'n woordekonomiese defi- 
nisie nie moontlik is nie of wanneer ruimtelike verhoudings nie weergegee kan word nie.

- Die illustrasies moet kompak wees, m.a.w. slegs die noodsaaklike attribute van ' $n$ konsep moet aangedui word.

- Illustrasies moet interpreteerbaar wees.

- Definisies moet anders geformuleer word waar illustrasies aangebied word.

- Alle tekeninge moet volgens dieselfde skaal gemaak word.

- Die dikte van lyne moet by tekeninge in aanmerking geneem word.

- Styl in tekeninge moet konsekwent wees.

- Kleur in tekeninge moet werklikheidsgetrou wees tensy anders aangedui.

3. Slot

In hierdie artikel is die kriteria vir ' $n$ Afrikaanse aanleerderwoordeboek saamgevat. Hierdie kriteria kan as eise en norme vir die beoordeling van 'n aanleerderwoordeboek vir swart tersiêre studente aangewend word.

\section{Verwysings}

\section{(a) Woordeboeke}

Cowie, A.P. en R. Mackin. 1975. Oxford Dictionary of Current Idiomatic English. Oxford: Oxford University Press.

De Villiers, M. et al. 1985. Nasionale Woordeboek. Goodwood: Nasou.

Homby, A.S. et al. 1942. Idiomatic and Syntactic English Dictionary. Tokio: Kaitakusha.

Hornby, A.S. et al. 1974. Oxford Advanced Learner's Dictionary of Current English. Oxford: Oxford University Press.

Kirkpatrick, E.M. 1980. Chambers Universal Leamers' Dictionary. Edinburgh: Chambers.

Procter, P. et al. 1978. Longman Dictionary of Contemporary English. Londen/Harlow: Longman.

Sinclair, J.M. (Red.). 1987. Collins COBUILD English Language Dictionary. Londen/Glasgow: Collins.

\section{(b) Ander bronne}

Al-Kasimi, A.M. 1977. Linguistics and Bilingual Dictionaries. Leiden: Brill.

Allen, H.B. $1964^{2}$. Linguistics and Usage. Allen, H.B. (Red.). $1964^{2}$. Readings in Applied English Linguistics. New York: Appleton Century Crofts.

Ayto, J.R. 1983. On Specifying Meaning: A Semantic Analysis and Dictionary Definitions. Hartmann, R.R.K. (Red.). 1983: 89-98. 
Ballweg-Schramm, A. 1981. Some Comments on Lexical Fields and their Use in Lexicography. Eikmeyer, H. en H. Rieser (Reds.). 1981. Words, Worlds and Contexts: New Approaches in Word Semantics: 462-467. Berlyn/New York: Walter de Gruyter.

Bejoint, H. 1987. The Value of the Dictionary in Vocabulary Acquisition. Cowie, A. (Red.). 1987: 97. 104.

Benson, M. 1985. Lexical Combinability. International Joumal of Human Communication 18(1): 3-14.

Brazil, D. 1987. Representing Pronunciation. Sinclair, J.M. (Red.). 1987: 160-166.

Bredemeier, J. et al. 1977. Überlegungen zu den syntaktischen und semantischen Informationen im Wörterbuch einer natürlichen Sprache. Petöfi, J.S. en J. Bredemeier (Reds.). 1977. Das Lexikon in der Grammatik - Die Grammatik im Lexikon: 65-88. Hamburg: Helmut Buske.

Cowie, A.P. 1978. The Place of Illustrative Material and Collocations in the Design of a Learner's Dictionary. Strevens, P. 1978. In Honour of A.S. Homby: 127-139. Oxford: Oxford University Press.

Cowie, A.P. 1979. The Treatment of Polysemy in the Design of a Learner's Dictionary. Hartmann, R.R.K. (Red.). 1979: 82-88.

Cowie, A.P. 1983. The Pedagogical/Leamer's Dictionary: I English Dictionaries for the Foreign Learner. Hartmann, R.R.K. (Red.). 1983: 135-143.

Cowie, A.P. 1987. Syntax, the Dictionary and the Learner's Communicative Needs. Cowie, A. (Red.). 1987: 183-192.

Cowie, A. (Red.). 1987. The Dictionary and the Language Learner. Tübingen: Max Niemeyer.

De Villiers, M. en F.A. Ponelis. 1987. Afrikaanse Klankleer. Kaapstad: Tafelberg.

Drysdale, P.D. 1987. The Role of Examples in a Learner's Dictionary. Cowie, A. (Red.). 1987: 213223.

Fox, G. 1987. The Case for Examples. Sinclair, J.M. (Red.). 1987: 137-149.

Geeraerts, D. en G. Janssens. 1982. Wegwijs in woordenboeken. Assen: Van Gorcum.

Gleason, H.A. 1967. The Relation of Lexicon and Grammar. Householder, F.W. en S. Saporta (Reds.). 1967: 85-102.

Gouws, R.H. 1984. Uitspraakleiding in Afrikaanse woordeboeke. Webb, V.N. (Red.). 1984. Kongresreferate: Linguistevereniging van Suider-Afrika: 279-302. Pretoria: Universiteit van Pretoria.

Gouws, R.H. 1986. Die taalkundige grondslae van die teoretiese leksikografie en die praktiese neerslag van taalkundige inligting in woordeboeke. RGN-verslag.

Gouws, R.H. 1987. Lexical Meaning versus Contextual Evidence in Dictionary Articles. Dictionaries 9: 87-96.

Gouws, R.H. 1988a. Compounds in Dictionaries: A Semantic Perspective. Snell-Hornby, M. (Red.). 1988: 91-97.

Gouws, R.H. 1988b. Die gebruik van etikette as leksikografiese hulpmiddel. S.A. Tydskrif vir Taalkunde. Geleentheidsuitgawe 6, 1988: 1-56.

Gouws, Rufus H. 1996. Leksikografiese behoeftevervulling. Lexikos 6: 171-183.

Hanks, P. 1979. To what Extent Does a Dictionary Definition Define? Hartmann, R.K.K. (Red.). 1979: 32-38.

Hanks, P. 1987. Definitions and Explanations. Sinclair, J.M. (Red.). 1987: 115-136.

Hartmann, R.K.K. (Red.). 1979. Dictionaries and their Users: Proceedings of the 1978 BAAL Seminar on Lexicography. Exeter: University of Exeter. 
Hartmann, R.R.K. (Red.). 1983. Lexicography: Principles and Practice. Londen/New York: Academic Press.

Harvey, K. en D. Yuill. 1997. A Study of the Use of a Monolingual Pedagogical Dictionary by Learners of English Engaged in Writing. Applied Linguistics 18(3): 253-273.

Herbst, T. 1984. Adjective Complementation: A Valency Approach to Making EFL Dictionaries. Applied Linguistics 5(1): 1-11.

Herbst, T.H. 1984. Bemerkungen zu den Patternsystemen des Advanced Learner's Dictionary und des Dictionary of Contemporary English. Götz, D. en T. Herbst (Red.). 1984. Theoretische und praktische Probleme der Lexikographie: 139-165. München: Max Hueber.

Householder, F.W. en S. Saporta (Reds.). 1967. Problems in Lexicography. Bloomington: Indiana University.

Ickler, T. 1982. Ein Wort gibt das andere. Auf dem Weg zu einem "Wörter-Lesebuch" für Deutsch als Fremdsprache. Linguistik und Didaktik 48-50: 3-17.

Ilson, R. (Red.). 1985. Dictionaries, Lexicography and Language Learning. Oxford: Pergamon Press.

Jackson, H. 1985. Grammar in the Dictionary. Ilson, R. (Red.). 1985: 53-60.

Jain, M.P. 1981. On Meaning in the Foreign Learner's Dictionary. Applied Linguistics 2(3): 274-286.

Kirkpatrick, E.M. 1985. A lexicographical dilemma: monolingual dictionaries for the native speaker and for the learner. Ilson, R. (Red.). 1985: 7-14.

Landau, S.I. 1984. The Art and Craft of Lexicography. New York: The Scribner Press.

Lemmens, M. en H. Wekker. 1986. Grammar in English Learner's Dictionaries. Tübingen: Niemeyer.

Lyons, J. 1977. Semantics. Volume 1 and 2. Cambridge: Cambridge University Press.

Maingay, S. en M. Rundell. 1987. Anticipating Learners' Errors - Implications for Dictionary Writers. Cowie, A. (Red.). 1987: 128-135.

Malone, K. 1967. Structural Linguistics and Bilingual Dictionaries. Householder, F.W. en S. Saporta (Reds.). 1967: 3-24.

Moon, R. 1987. The Analysis of Meaning. Sinclair, J.M. (Red.). 1987: 86-103.

Mostert, N. 1988. Die funksie van sitate en poëme in die verklarende leksikografie. Tydskrif vir Geesteswetenskappe 28(2): 150-160.

Moulin, A. 1987. The Dictionary and Encoding Tasks. Cowie, A. (Red.). 1987: 105-113.

Nickel, G. (Red.). 1972. Fehlerkunde: Beiträge zur Fehleranalyse, Fehlerbewertung und Fehlerterapie. Berlyn.

Nuccorini, S. 1988. The Treatment of Metaphorical and Idiomatic Expressions in Learners' Dictionaries. Snell-Homby, M. (Red.). 1988: 149-160.

Otto, A.N. 1989. Kriteria vir 'n Afrikaanse aanleerderwoordeboek. Ongepubliseerde D.Litt.-verhandeling. Stellenbosch: Universiteit van Stellenbosch.

Orszagh, L. 1969. Wanted? Better English Dictionaries. English Language Teaching 27(3): 216-221.

Ponelis, F.A. 1979. Afrikaanse Sintaksis. Pretoria: Van Schaik.

Ponelis, F.A. 1989. Leksikale elemente. Botha, T.J.R. (Red.). Leksikografie en leksikologie. Pretoria: Serva: 48-54.

Read, A.W. 1982. Theoretical Basis for Determining Pronunciation in Dictionaries. Dictionaries 4: 87-96.

Richards, J.C. en R.W. Schmidt (Reds.). 1983. Language and Communication. Londen/New York: Longman.

Sinclair, J. 1987. Grammar in the Dictionary. Sinclair, J.M. (Red.). 1987: 104-115. 
Sinclair, J.M. (Red.). 1987. Looking Up: An Account of the Cobuild Project in Lexical Computing and the Development of the Collins COBUILD English Language Dictionary. Londen/Glasgow: Collins ELT.

Snell-Hornby, M. (Red.). 1988. Zürilex '86 Proceedings. Zürich: Francke.

Stein, G. 1979. The Best of British and American Lexicography. Dictionaries 1: 1-23.

Stein, G. 1985. Word-formation in Modem English Dictionaries. Ilson, R. (Red.). 1985: 35-44.

Strevens, P. 1987. The Effectiveness of Leamers' Dictionaries. Burchfield, R. (Red.). 1987. Studies in Lexicography. Oxford: Clarendon Press.

Tomaszczyk, J. 1987. FL Leamers' Communication Failure: Implications for Pedagogical Lexicography. Cowie, A. (Red.). 1987: 136-145.

Underhill, A. 1985. Working with the Monolingual Learners' Dictionary. Ilson, R. (Red.). 1985: 103114.

Van Els, T. e.a. 1984. Applied Linguistics and the Learning and Teaching of Foreign Languages. Londen: Edward Amold.

Van Roey, J. 1988. Work in Progress: A Parallexicon of English-French "Faux Amis". Snell-Hornby, M. (Red.). 1988: 161-169.

Webb, V.N. 1983. Die taalwetenskap as sosiale wetenskap. Claassen, G.N. en M.C.J. van Rensburg. (Reds.). 1983. Taalverskeidenheid: 229-246. Pretoria/Kaapstad/Johannesburg: Academica.

Wekker, H. en P. Hyams. 1979. De Longman Dictionary of Contemporary English (review article). Levende Talen 342: 406-417.

Wells, J.C. 1985. English Pronunciation and its Dictionary Representation. Ilson, R. (Red.). 1985: 4552.

Wells, R.A. 1973. Dictionaries and the Authoritarian Tradition: A Study in English Usage and Lexicography. Den Haag/Parys: Mouton.

Wendland, E.R. en E.A. Nida. 1985. Lexicography and Bible Translating. Louw, J.P. (Red.). 1985. Lexicography and Translation: 1-52. Kaapstad: Bybelgenootskap van Suid-Afrika.

Whitcut, J. 1978. Lexicography in Controlled Vocabulary. Paper presented at the AILA conference. Montreal.

Zgusta, L. 1971. Manual of Lexicography. Den Haag/Parys: Mouton. 


\title{
The Macquarie Dictionary, its His- tory and its Editorial Practices
}

\author{
Arthur Delbridge, Emeritus Professor, Macquarie University, and formerly \\ Editor-in-Chief, Macquarie Dictionary, and \\ Susan Butler, Publisher, Macquarie Dictionary, Sydney, Australia
}

\begin{abstract}
The Macquarie Dictionary, first published in Sydney in 1981, was intended to be the first comprehensive dictionary of Australian English. Now in its third edition it has been widely adopted by institutions and the general community as the national dictionary. This paper traces its development from a difficult birth to its present maturity, from a large set of cards to an electronic database, from a single book to a lexicographic library. The rationale and the methodology are laid out along with an account of the reception given to the dictionary in Australia and internationally.
\end{abstract}

Keywords: DICTIONARY, LEXICOGRAPHY, MACQUARIE DICTIONARY, AUSTRALIANNESS, AUSTRALIANISE, AUSTRALIAN ENGLISH, NATIONAL DICTIONARIES, PHONOLOGY, INTERNATIONAL PHONETIC ALPHABET, LEXICAL LABELS, LEXICOGRAPHIC STYLE, LANGUAGE STYLE, COLLOQUIAL, ABORIGINAL WORDS, ELECTRONIC DATABASE, CORPUS, CITATION

Opsomming: Die Macquarie Dictionary, sy geskiedenis en sy redaksionele praktyke. Die Macquarie Dictionary wat vir die eerste keer in 1981 in Sydney gepubliseer is, waś bedoel om die eerste omvattende woordeboek van Australiese Engels te wees. Die woordeboek wat tans in sy derde uitgawe is, word reeds algemeen deur instansies en die algemene publiek as nasionale woordeboek aanvaar. Hierdie artikel skets sy ontwikkeling vanaf ' $n$ moeilike geboorte tot sy huidige volwassenheid, vanaf ' $n$ groot versameling kaartiles tot ' $n$ elektroniese databasis, vanaf ' $n$ enkele boek tot ' $n$ leksikografiese biblioteek. Die grondbeginsels en metodologie word gegee saam met ' $n$ verslag van die ontvangs wat dit in Australië en internasionaal gekry het.

Sleutelwoorde: WOORDEBOEK, LEKSIKOGRAFIE, MACQUARIE DICTIONARY, AUSTRALIESHEID, AUSTRALIANISEER, AUSTRALIESE ENGELS, NASIONALE WOORDEBOEKE, FONOLOGIE, INTERNASIONALE FONETIESE ALFABET, LEKSIKALE ETIKETTE, LEKSIKOGRAFIESE STYL, TAALSTYL, OMGANGSTAAL, ABORIGINELE WOORDE, ELEKTRONIESE DATABASIS, KORPUS, AANHALING

The Macquarie Dictionary is a national dictionary of Australian English, edited by Australian lexicographers, its major editions printed and produced in Australia, with residents in Australia as its envisaged principal users. It is international only in the sense that the English language itself is a world language with a so-called common core and many local varieties, Australian English 
being one of them. The concept Australian English is relatively new, first introduced as recently as the 1940 s. But by the 1990 s it was securely entrenched in popular usage and a basic reference point even in the language policies of the Australian Federal Government. An account of this development may be found in two articles by Delbridge (1992 and 1999).

\section{The need for a monolingual dictionary of Australian English}

English has been in use in Australia since 1788, when Captain Arthur Phillip brought his fleet from Portsmouth to Botany Bay, with a company of civil and military officers and marines, and of course some seven hundred and fifty convicts, to form a settlement, to cultivate the land by convict labour so as to provide grain and other food supplies, to open an intercourse with the indigenous population, and to establish a new British colony (Clark 1963: 20). From then on, for more than a century, this British colony grew, though never easily, by adapting to a new climate, to shallow soil seriously deficient in nutrients, to an indigenous population with whom it rapidly came into conflict over differences of culture, language and intentions. But in time it achieved a sort of competence, by means of exploration, internal migration, the establishment of new population centres throughout the habitable parts of the continent, and by turning the convicts who had served their time into independent land holders, farmers, builders, architects, lawyers and writers, alongside the free settlers who had come from Britain to Australia as to a land of opportunity. Towards the close of the 19th century there were more native-born citizens than immigrants, and Australia was already made up of six independent states, each with its own colonial government. But in 1901 these states became federated into the Commonwealth of Australia, with a Federal parliament (as well as the six State parliaments) and a British Governor-General. In the first national census, taken that year, it was revealed that $77 \%$ of its population of 3773801 persons were born in Australia, 10\% of them in England and Wales, 3\% in Scotland and 5\% in Ireland. Only 5\% had been born in a non-English-speaking country, or America. Australia was virtually monolingual, and English was its language. (Australian Aborigines did not have citizenship, and neither they nor their languages were counted in that census.)

At Federation, English had been Australia's language for more than a century, and it had to express (in relative geographical isolation) the novel realities of this antipodean land, its strange flora and fauna, the extraordinary. circumstances of its social origins, its patterns of settlement, the growth of its institutions in government, law, education, labour relations, religion, the arts and sport. Inevitably English in Australia diverged from English English in vocabulary, pronunciation, spelling and idiom. Much of the published writing of the time was done by English-educated writers, who tended to avoid what they might have thought of as Australianisms. Many of the early novels were published in England, and the novelists were keen enough to use Australian 
idiom in passages of dialogue, but then to explain to readers in England what these strange expressions might mean (Webby 1988). One dictionary was published, with the aim of listing "all the new words and new uses of words that have been added to the English language by reason of the fact that those who speak English have taken up their abode in Australia, Tasmania, and New Zealand" (Morris 1898: xi).

That dictionary was not enough. Well into the 20th century, Australians have been without a comprehensive dictionary that focused on their own variety of English, not just its slangy idioms, but on all of its English, a book in which Australianisms did not have to be labelled as if they were peculiarities outside the range of normal English, and in which Australian English might become the basis of comparison with other national varieties of English. The dictionaries available in Australian bookshops for general use in the adult population were predominantly British - those from Oxford, Chambers, Longmans, etc. American dictionaries were not in wide use, since American English itself was largely but ignorantly deprecated by the Australian public, as was their own local variety. The history of the Macquarie Dictionary is the story of an attempt to supply what had been lacking, and to promote acknowledgment of the local variety, with a comprehensive dictionary. Not the first attempt, certainly, but the only one of the early attempts which actually attained publication.

\section{How it began}

As with so many projects which come to fill if not dominate the lives of those who participate, this one began with a fairly casual offer from a publisher. It came, late in 1969, from Brian Clouston, the head of the Jacaranda Press, Brisbane, a publishing house dealing principally with educational books. It was casual in the sense that he did not consult his board before making an offer, and the offer did not include a contract. Made to Arthur Delbridge, who was the foundation professor of linguistics in Macquarie University, it proposed the writing of "an aggressively Australian dictionary", to be finished and ready for publication in two years' time, with funds enough to encourage the participation of a small group of academic editors, a support staff, and office accommodation off campus. The university itself was not involved in the initial arrangement, though clearly it needed to give permission to its own academic staff who became involved. More importantly, the offer included the use of a dictionary of suitable size, the Encyclopedic World Dictionary (EWD), as a base on which the new work could be developed. This dictionary had itself been based on the American College Dictionary (ACD) (1947-1967), with Patrick Hanks as editor and the Hamlyn Publishing Group Ltd as publisher. It was published in London in 1971. The $A C D$ was never on sale within Australia, and the subsequent work on the proposed Jacaranda Dictionary (to give the Macquarie Dictionary its first intended name) ignored it completely in favour of EWD. EWD itself 
had been available to Australian users only through a successful mail-order campaign of short duration in 1972. It was a revision of an American dictionary by a British lexicographer whose first concern was "to describe the vocabulary common to all or most brands of English in the fullest and clearest possible form" (Hanks 1971: Introduction). It was not in any sense a national dictionary, but it proved to be Australia's indispensable base dictionary.

\section{Which way to go?}

Work began with a group of four academic editors, Arthur Delbridge as chairman of an editorial committee, and J.R.L. Bernard, D. Blair and W.S. Ramson the other members, the first three all teachers of linguistics at Macquarie University, Sydney, and Ramson at the Australian National University, Canberra. All had had lexicographic experience, especially as consultants to English or American publishers, contributing Australian lexical material to more or less international dictionaries whose editors wished to have an Australian component within their wordlists. Now for the first time the members were confronted with the job of initiating a policy, considering a style, working out a method of data collection, assuring authenticity, and securing a readership. The possession of a base dictionary, as of right, both simplified and complicated these tasks. Nobody believed the would-be publisher's time scale of two years to be achievable for a book modelled in some degree on another which was almost 2000 pages long. And nobody wanted it to be patently aggressive in delineating Australian English. Indeed, when the work was finished, and a publisher found, he refused to have the words Australian English in the title, fearing that buyers might be put off by an expectation that this was nothing more than an account of local Australian slang (which, though widely used, was commonly deprecated).

There was a view current among scholars working in the field of Australian English that the first priority was for a historical dictionary to be written. The Sydney University Australian Language Research Centre, founded in 1962, believed the only excuse for writing a general descriptive dictionary of current Australian English was that money from its sales would finance the research needed for a scholarly historical account of Australianisms. But the Macquarie team took a different view: the most urgent need was for a people's dictionary that would hold up the mirror directly to contemporary Australian speech and writing as its first object of study. When eventually a historical dictionary was produced, it was edited solely by Ramson (1988), whose contribution to the first edition of the Macquarie Dictionary had, as he put it in a prefatory essay, presented "the fullest available record of Australian additions to and modifications of the vocabulary of English" (Delbridge et al. 1981: 37). This meant that the users of that edition, as of subsequent editions, had more than an account of contemporary Australian English: they had also a key to the colonial, 19thcentury vocabulary to be met in public records and works of literature. 


\section{Towards the first edition (1970-81)}

Closer inspection convinced the editors that EWD was a very good dictionary, likely to serve well as a base. Since it was obvious that much of it would be retained in the new dictionary, the editors' first decision was that the EWD style would be largely followed in matters of layout. In those early days English lexicography had not been influenced by the COBUILD defining style, and in any case this was not to be a learner's dictionary, but one to be used by those members of the Australian community who felt the need for a comprehensive coverage of Australian English in dictionary form. So the EWD defining style was also adopted, with modifications to be made later in the light of experience.

\section{(a) The wordlist}

Those parts of its wordlist that belonged to the common core of English around the world could well be taken over into the new dictionary, updated or otherwise modified. But many of the common words of world English have uses in Australia that were not adequately covered in EWD. Also individual judgments had to be made about deleting some entries relating to aspects of life in England, Scotland, South Africa, etc. The EWD had apparently had an unbridled African consultant whose enthusiasm for geelslangs (Cape cobras), geelbeks (yellow bill ducks) and maasbankers (horse mackerel) now had to be restrained, in order to make room for geebungs, wombats and echnidas - not out of invincible parochialism, but for space. The publisher had specified a single volume, with a page size like EWD's, and an eye-friendly typography, so to fit in a comprehensive account of Australian words, idioms and meanings, room had to be created, by excision.

Then there were the specialist areas: the sciences, the technologies, the arts, law, sport, language and languages (especially Aboriginal languages), economics, politics, education, religion, and many others. All of these had undergone local modification throughout Australian history, and some had uniquely Australian features. For editorial purposes all the related words and phrases had to be recovered from the base dictionary, whether adequately labelled there as belonging to one of the special fields or not, and submitted to properly instructed local specialists, for judgments for or against their retention, with or without updating and other modifications. And specifically Australian words and phrases in these specialist fields had to be added. The committee's major task, however, was to assemble the ordinary words, phrases and idioms of Australian English, attending to the whole range of social styles and registers, using both written and speech texts as data. For any headword entered, policy decisions had to be made as to pronunciation, spelling, grammatical status, etymology and labelling. 


\section{(b) Pronunciation}

All the editors had been involved in major studies of the phonological patterns of Australian English across the community. So, contrary to general practice except in learner's dictionaries, they decided to supply an Australian pronunciation, with variants, for every headword entry, using a suitable version of the International Phonetic Alphabet. The transcription symbols were to be phonemic, each accommodating within a single symbol the whole spectrum of variation found among Australian speakers. Thus not one of the three major categories of Australian pronunciation, Broad, General and Cultivated, would be favoured over the others, and every user could interpret the transcription in terms of their own position in the spectrum (Mitchell and Delbridge 1965). In the first edition of the dictionary (Delbridge et al. 1981) a detailed account of the pronunciation of Australian English and its treatment in the dictionary is given in a prefatory essay by J.R.L. Bernard (Delbridge et al. 1981: 18-27).

\section{(c) Spelling}

Nineteenth-century British spelling prevailed in the Australian colonies, and has continued to prevail in classrooms throughout Australia ever since. However, American influence has also become strong, with the result that Australian spelling shows the influence of two schools. But it is not a patterned influence, and individual words yield to it, or not, in a way that betokens a sort of independence in Australian writers. One result of this is that the Macquarie editors need to acknowledge variants in spelling whenever they are established in competent use. To do this securely they need to collect a lot of data to support their acknowledgment of variants which might, even so, displease the conservatives of the community. It was only after the publication of the first edition that they saw that the picture was not as clear as they had assumed. As subsequent corpus studies then showed, the effects of American English on British spelling norms in Australia were extensive but by no means regular. Every word had to be treated individually as to its variants. The elaboration of their treatment of this variance is evident from the second edition onwards.

\section{(d) Labelling}

The EWD used a set of three types of labels: subject labels, regional labels and language labels. Attempting to follow this pattern the editors found that the subject labels presented a problem in the open-endedness of the list. They economised by distinguishing between single-definition and multi-definition entries. For the latter, labels were used to act as signposts to alert the reader of a change from one context or field to another. They rewrote the single-definition entries so that they could obviously stand without a subject label. 
The editors were not persuaded that the EWD language labels slang, taboo, and taboo slang were capable of consistent use. They did not always reflect contemporary mores, at any rate in Australia where the wilder shores of vocabulary tend to be quite familiar territory. They felt that the users of this dictionary, who would not be learners, should not have too specific a categorisation applied to some of their familiar words. The word slang is not easily defined, and (to quote the editor of Webster's Third New International Dictionary) "no word is invariably slang" (Gove 1971: 19a). The editors decided instead to use the label colloquial for a wide range of informal expressions, leaving it to the user to decide appropriateness in particular social settings. (This view was modified but not disowned in the third edition.)

Some headwords have restrictive labelling in the form of the symbol $\neq$. This indicates that the word itself may give offence essentially because of its taboo nature. The use of two symbols $(\ddagger \neq)$, applied to a small group of words, indicates an extreme degree of this restriction. A single symbol ( $\ddagger)$ is also used if there is a particularly crass and offensive meaning given to a usually neutral word. Taboo words are to be differentiated from words which are intended to offend, in particular racist terms, which are labelled derogatory (Delbridge et al. 1997: xxi).

\section{(e) Grammar}

The editors agreed that the grammatical categorisations in $E W D$, even though they did not reflect the mid-century grammatical stirrings among linguists, were nevertheless safe, useful and familiar. And with so much else to do (in two years?) they gratefully deferred modifying the EWD system, at least for the time being. The EWD practice of giving part-of-speech labels only to singleword entries was extended to other entries such as compound nouns.

\section{(f) Etymology}

The EWD etymologies were as supplied by Kemp Malone, and with some modifications of style they were retained for the words taken into the new dictionary from the base dictionary. Among the added words, many of them Australianisms, etymologies were written in the same style. But for the words taken into English through contact with the many Aboriginal tribes encountered throughout Australia in the processes of settlement there was a difficulty. Only some of these languages had been closely studied, either by linguists or missionaries; some no longer had any living speakers; none of them were written languages. So writing the etymology of words like myall, coolibah, brigalow and boong presented difficulties - so often there was no information. The editors had to wait until the late 1980 s for research that could specify the Australian language from which each of such borrowings had come (Dixon et al. 
1990). So for the first edition their etymology consisted only of the word [Aboriginal], but in the second and subsequent editions it has been possible, in the light of new research in Australian languages, to name the source language of each of the Aboriginal borrowings.

\section{History of the first edition up to publication}

The primary research task was to find the new material to be added to the base dictionary so as to produce a comprehensive record of the language. The primary editorial task was to slot the research material into a dictionary structure and a typographical plan. In later times the editors separated the dictionary structure from the ultimate appearance of the text on a printed page, but in this early stage the two were indistinguishable: their concept of the structure of an entry came from an analysis of the printed form of the base dictionary. Typeface, positioning, punctuation, etc. - all had lexicographic meaning. For example, there was a pattern in the etymologies comprising a language name followed by a colon followed by a gloss, indicating that the word in the language of origin had the same form as the headword and therefore did not need to be repeated, a subtlety that has escaped the notice of many readers of the dictionary over the years. Belief in the acceptability of the total structure was challenged once the transfer was made from cards to computer typesetting. What had seemed perfectly comprehensible to the editors seemed quite illogical to the programmer, who nevertheless felt that his task was to database the dictionary as it had been structured. Later programmers were not so respectful. It was not until the third edition that pressure came for the editors to comply with a logical database structure that was uniform throughout the whole range of Macquarie dictionaries. The original database was servant to the book, but by the mid-90s the book has become the incidental by-product of the database.

When work was finished for the first edition, it was still all on cards, but photocopied for security. In 1974 Jacaranda had a new British owner who was pressing for immediate publication in spite of the editorial committee's assertion that the work was not yet ready. But the message was clear: to publish immediately. The cards and the photocopy were sent to the publishing house next to the Brisbane River which, in a record flood, came within inches of destroying the material. A portion of the manuscript was sent to three international referees for judgment. All three commented favourably, commending the decision on the use of IPA for pronunciations, recognising the value of the strong Australian component, accepting the justification for the colloquial label, and agreeing that this was essentially a new text being prepared to meet a welldefined need. Useful suggestions were made and in time followed. In the meantime Jacaranda decided to import an English editor experienced in lexicography, who would take over the manuscript and prepare it for immediate publication. But in 1975 the whole project was closed down, its support 
staff dismissed, and the manuscript stored away in Jacaranda's Brisbane premises.

There were two resolves: to get the work finished, and to find a publisher for it, Jacaranda or some other. For the first of these, Macquarie University stepped in. It had earlier approved of the dictionary involvement of Delbridge, Bernard and Blair over the years, on the understanding that the work was part of the research commitment expected of academic staff. There had never been an expectation on either side that any of them would be relieved of any portion of their teaching and administrative duties. But the University did not want to see the years of work go for nothing, and it had begun to see ultimate publication as good for the university too. So the university made a formal agreement with Jacaranda to become joint owners of the manuscript with them, and to provide funds at least for the employment of Susan Butler as senior research assistant on the project for two years, for no one knew the state of the manuscript better than she already did. The agreement gave Jacaranda the option to publish at the end of the two years that now seemed necessary to finish the work. If Jacaranda did not publish then, another publisher would be sought.

It became apparent that Jacaranda would not proceed. It now had an American owner, Wiley of New York, who was surprised but pleased to discover that what he had just bought included a dictionary manuscript almost ready for publication. But the estimated cost of producing the book was one and a half million Australian dollars, and the Jacaranda board of management found the terms offered for an American commitment of this size unacceptable. Jacaranda indicated that it had to decline to publish a work it had supported since 1970.

In the meantime Jacaranda had been making unsuccessful approaches for financial support elsewhere, including one to the Federal Government. Its response was negative. So it was left to the editorial committee to find its own publisher, with useful input from both Macquarie University and the Australian National University, where Ramson was a teacher. Among those approached there was no lack of enthusiasm for the notion of a locally produced dictionary focused on the use of English in Australia. The fundamental problem was a doubt among publishers that a new and local dictionary could find favour from a public already accustomed to buying overseas dictionaries, especially the Oxford dictionaries of various sizes. Market research showed that it would take five years to recover from sales the initial cost of paper, printing, binding and distribution. The book was unlikely to have any significant international sales, and the financial returns would be too small and too slow. This was the verdict of all the publishers approached, whether they were Australian branches of international companies, or purely local. Finally, a consortium was attempted, including the Australian Broadcasting Commission $(A B C)$, the Literature Board of the Australia Council for the Arts, the Australian National University Press (whose current manager was the same Brian Clouston who had first approached Delbridge with the original idea), 
and the Macquarie University. Under this plan the Literature Board would give some funds, the Broadcasting Commission would arrange distribution, the ANU Press would produce the book, and Macquarie University would provide computing equipment with which the editors could turn its thousands of cards into electronic form and produce the dictionary camera-ready (all 2000 pages of it) for printing and binding in Canberra, with all the expected royalties from sales to go towards the work of producing a historical dictionary of Australian English also in Canberra. This plan failed, initially because the Broadcasting Commission found that its charter allowed book publication only of text arising directly from material it had already broadcast. Academic editors and staff could also not produce by a new technology a large typographically complex book which established publishers had already rejected.

But in 1978 a new player arrived on the scene. He was Kevin Weldon, who had been manager of Hamlyn Australia in Brisbane in time to make that brief mail-order promotion of the EWD. He knew of the work and was about to launch himself as a publishing proprietor. He was, and indeed still is, a strong supporter of Australian enterprise, and it suited his plans as an entrepreneurial publisher to have in his portfolio a major reference work associated with a respected Australian university. He asked for some months to look at the possibilities, then dealing directly with the university he agreed to publish the work, with Macquarie Dictionary as its name, and to set up a company which would distribute it by mail order through one major capital city newspaper in each state of Australia. A period of readying the work followed, concentrating on local development of electronic programs for a dictionary database that would not only facilitate printing but also the work of revision and correction for later editions, as well as the production of spin-off dictionaries.

\section{Method of compilation}

For the first edition of the dictionary the starting point was a huge card file created from the base dictionary. A team of schoolchildren for whom this was a summer holiday job had laboriously cut and pasted each entry of the dictionary onto.its own card. It worked well enough although there were occasional obvious lapses of application to the task.

The major additional file was the editors' own citations collection file which grew almost as rapidly as they sifted through the obvious secondary sources and then began a program of reading of primary sources. These were largely contemporary materials - books, magazines, newspapers, etc.

Other files grew as editing progressed. One initial task was to provide specialists with material that related to their special field so that these lexicons could be considered from an Australian perspective as well as brought up to date. Since the meaning that related to the specialist field was often one of many unmarked meanings, the only way to do this was to duplicate the entry and set up a separate card file for each specialist area. Not every specialist set 
of definitions in the dictionary was revised in this way but the major ones were, and the ones which the editors felt had great significance to Australians, and therefore to Australian English. There was not much they wanted to say about the sport of curling for example but quite a lot to add under the headings of agriculture, botany, history and politics, and zoology. In terms of general updating economics, computing and medicine were as much in need of updating then as they would be for an edition produced today.

It was a slow procedure made inevitably cumbersome by the card files. The day-to-day writing of the dictionary was a matter of transferring data from one card to another. A process that affected the whole dictionary was the amount of filing involved. The collection of new material relied largely on an individual's knowledge, or on the happenstance of the reading programs. It helped to have a good memory in these circumstances to be able to say with some certainty what was in the file and what was not, and which particular file it was in.

Everyone who worked on the dictionary became attuned to capturing words on the run - as you read them in the paper in the morning, as you listened to the radio in the car, as you conversed with others.

The fear that drove all on at that stage was that some obvious lexical item of Australian English would be left out. The secondary sources available took the editors up to World War II. There had been some work on particular areas of Australian English at Sydney University but these were, on the whole, historical studies. The editors had to document Australian English from World War II onwards from scratch and had to sieve through the existing material selecting what was appropriate for the dictionary. In all this it was quite possible that something might be missed.

The basic commitment of this dictionary was that it would have all the words in it that a speaker of Australian English would expect to find. What if the first edition appeared and it was without the entry for fair dinkum or dingo or some such? It was this anticipated possibility that produced the scraps of paper, the backs of chequebooks, the anxious before-I-forget phone calls, just to check that a word was where it should be and had not been overlooked.

This was the research aspect of the task that confronted the first editorial team. This had to be complemented by an editing process that took the new material and slotted it into a dictionary structure. The principles for selection were as they have ever been: first, establish that the word has currency, or has had currency, in the language community; then try to establish its meaning in accordance with the evidence of its use; then provide information on morphology, etymology, and so on, for the final dictionary entry. Although the method is timeless, the means by which currency is established has changed over the years with access to huge corpora as instant suppliers of citational evidence. 


\section{Publication, Reviews}

The first edition of the Macquarie Dictionary was launched in Sydney on 21 September 1981 by Professor Manning Clark, Australia's foremost and most venerated historian, who in his printed Introduction to the work had described it as "a landmark in the history of this great change which has come over intellectual and cultural life in Australia" (Delbridge et al. 1981: 11). The first print run of 50000 copies sold out within three months and the up-front bills were all paid. It was reprinted seven times with additions and corrections before the second edition appeared in 1991.

The reviews were welcoming and (especially the non-professional ones) very enthusiastic. The academic and specifically lexicographic reviews, both overseas and local, were not discouraging. Writing in A Bibliography of Writings on Varieties of English, 1965-1983, Broder Carstensen expressed a favorable view:

Dem Leser dieser Zeitschrift sei verraten, daß dieses Wörterbuch des australischen Englisch eine der größten (die bedeutendste?) Leistungen der australischen Anglistik und der modernen englischsprachigen Lexikographie überhaupt ist.

The most sobering of the reviews was by Dr R.W. Burchfield, published in the Monthly Review supplement of the Melbourne paper The Age (1 March 1982: 1011):

The reasons one might adduce for believing that it is a strictly local triumph and not an international one lie in two main directions, its primary derivativeness and its occasional charming unawareness of the standard professional requirements of reputable lexicography outside Australia.

He did not hold the editors' use of the base dictionary to be reprehensible, but he did expatiate on the extent of their retention of English and American material from it, which he estimated at $93 \%$. But English as a world language is principally formed in the populations of England and America, and the editors did not wish to exclude the English and American material. Dr Burchfield appears not to have taken into account, in his equation, the extent of Australianisation done even on his estimated 93\%. For example, of the first 100 botanical entries under the letter $B$ in the first Macquarie edition there were only 43 which also appeared in the $A C D$, and of these only 13 in Macquarie Dictionary are as they stand in $A C D$, disregarding the pronunciations and etymologies which are in each case altered: In the area of linguistics the editors deleted all but the most important American Indian languages, and replaced them with 
the names of Aboriginal languages. In law, parliamentary procedure and industrial relations they put Australian instead of American definitions of the words that happened to occur in both varieties, and added those that are unique to Australia. Pronunciation and spelling variants current in Australian English are entered with a priority based on observation and record. Every headword has a pronunciation based on wide personal observation and census-taking, on the accumulated files of the ABC's Standing Committee on Spoken English (SCOSE), and on the published studies of the phonology of Australian English. The publisher of the dictionary eventually paid many thousands of dollars in a single royalty sum to Random House, publisher of the $A C D$, which had not been used as a base, and a lesser sum to Hamlyn. The use of the Hamlyn book is gratefully acknowledged early in the first preface, though not on the title page, as Dr Burchfield would have preferred. Such reference would have meant very little to the Australian readers because only a very small number of copies of EWD were still to be found in Australia, and, except perhaps in university libraries, none of the $A C D$. No purchaser of the Macquarie Dictionary has complained of having been misled by the notice given in the preface. In the publishing context in which Macquarie Dictionary appeared, the reference to the history of the book seemed to the editors to be both accurate and appropriate. The publisher had no plans to offer the book for sale in Europe or America, though people there who wanted it as an Australian dictionary could, and did, find ways of securing their copy.

\section{Community acceptance}

The publication of the first edition of the dictionary in 1981 was rewarded with instant acceptance by the majority of Australians. The penetration of the dictionary was mapped by the responses the editors received to a newsletter which came with the book inviting dictionary users to become contributors to ongoing work. This was the first appearance of the Macquarie Dictionary Society Newsletter which was designed to harness the enthusiasm of Macquarie Dictionary owners around Australia. The first editorial (Macquarie Dictionary Society Newsletter 1(1): 1, October 1981) read as follows:

It is impossible to have been everywhere, seen everything, and spoken to everyone, particularly in a country as big as Australia. So we know that while the Macquarie Dictionary is a comprehensive account of Australian English, there will be words we have missed, pronunciations which we have not recorded. People can add to our store of knowledge by pointing out to us these areas for future research. Perhaps it is just a single word, perhaps a whole feature of Australian life, which should be investigated and recorded. The Macquarie Dictionary Society will, we hope, be supported by people who will map out the aspects of Australian English yet to be explored. 
The newsletter under a new title, Australian Style, has a national distribution, and is published by the Style Council Centre of Macquarie University with funding assistance from Language Australia, an organisation set up by the Federal Government.

It took a while to establish the claim that the Macquarie Dictionary was the national dictionary. The position of the dictionary was made more secure by a 1986 conference, which became the first of many, on aspects of Australian English. The conference was called Style Council since it addressed matters of style and usage, and since it was thought of as bringing together different people who had an interest in those issues as a kind of representative gathering. Linguists and lexicographers were present but outnumbered by teachers, writers, and editors. The first Style Council addressed topics which were of immediate concern to the dictionary editors - spelling, hyphenation, capitalisation and so on - but later conferences took themes of a more general nature but still focused on language and on Australian English in particular. The Macquarie Dictionary has been accepted as the arbiter of Australian English by many newspapers where it is the bedrock of a house style; in the law courts where Macquarie definitions are given priority over those of all other dictionaries; in Hansard, whose editors have declared it to be their "bible"; in the ABC for pronunciations; in the Commonwealth Government Style Manual (Grayston 1994); and in the education system where the Australian Education Council (now called the Council for Education, Employment, Training and Youth Affairs), comprising the state and territory Ministers of Education, agreed to take Macquarie as the standard reference on Australian spellings.

\section{The range of dictionaries}

If the editors had been tempted not to continue when the first dictionary was published, the publisher prevented this. Kevin Weldon had always envisaged that the Macquarie Dictionary was the starting point for many other dictionaries for different kinds of users. The first in the series had been decided in the original contract - a Pocket Dictionary for Australian schools. But there were to be others in the family for the general market, the education market and the children's market. Each one had its own users. The Pocket Dictionary was prepared in consultation with a range of teachers who advised on the vocabulary of different subject areas. It was a first stab at a controlled defining vocabulary of sorts, a procedure that the editors have refined for the ESL dictionaries, now in preparation. The Concise Dictionary on the other hand needed a greater range of subject areas, from components of the formal curriculum, such as physics, geography, etc., to activities which by their nature are considered informal, such as horseracing, gambling, surfing, etc. It also needed a broader sampling of colloquialisms. Each dictionary was derived from the comprehensive dictionary in that a headword selection from that database produced the first draft of each new dictionary. But from that point on much had to change, so much so 
that the editors opted eventually for a set of dictionary databases related by a common structure rather than just one dictionary database with multiple options.

On top of this dictionary program the work of creating a thesaurus was begun by using the comprehensive dictionary as the starting point. And this again led to a sequence of thesauruses to match the dictionaries.

It took ten years to establish the family of dictionaries and thesauruses. It was a process of coming to terms with the obvious from both a publishing and a lexicographical point of view: the publishing company would not survive on just one dictionary when its competition had the depth and strength of a range of dictionaries, internationally marketed. And not all the people who wanted an Australian English dictionary necessarily wanted it in its first format: different users needed different kinds of dictionaries.

\section{The computer system}

Card files had been the basis of the work from the time that the project began in 1970 to the typesetting of the first edition for publication in 1981. With the typesetting of the first edition this was not necessary. They transferred the data from card files to a computer database, but one to which they did not have direct access. The computer that stored the database was held by the typesetters at a location remote from the editors in Adelaide, the capital of South Australia. It was a cumbersome way of doing things, but preferable to the card system.

The great advantage at this stage was that searches of the whole database could be conducted, giving the editors a secure knowledge of precisely what was in and out of the dictionary.

The editors wished to have direct access to the database and developments in computer technology soon made this possible. The huge computers which housed the original database became museum pieces and Macquarie Dictionary was able to obtain a relatively tiny computer which was the central server to a local network. The software system used was one called Titan, developed by RMIT University computing department in Melbourne. It had been designed as a library system, so its strength was that it could search huge amounts of data very quickly and keep track of what happened to that data as it underwent various processes.

It was not particularly user-friendly, and the staff themselves had to write all the special software that they needed for dictionary use. For example, they set up a corpus of Australian texts on this system which they called Ozcorp. Ozcorp is a database of Australian English collected for lexicographical purposes. It contains at present approximately 23 million words, with significant representation from Australian fiction, non-fiction and newspapers. Although there is a bias towards contemporary material, the database includes many 
texts from the 19th century through to World War II. There is also a small amount of material derived from letters, advertisements, and some spoken transcriptions.

The searching facilities of Titan on this corpus were swift so that it became an easy tool to use in the day-to-day work of dictionary editing. The facility to line up the corpus and the dictionary side by side meant that any entry that attracted the editor's eye for whatever reason could also, as part of the editing routine, be checked against Ozcorp. Suddenly the editors found themselves in the position to reshape the dictionary in a way that has greatly reduced their dependency on the base dictionary.

They still kept a kind of computer notebook alongside Ozcorp for the things that they noticed in their daily reading and listening, for human beings were still best at picking up useful items for the dictionary. They also experimented with using the computer to identify new words. As each text was scanned for Ozcorp they ran the dictionary spellchecker over it, in effect asking what words were in the text that were not in the dictionary. The results were overwhelming and, they realised, mostly full of material that was not needed in the dictionary anyway. It is a procedure that needs to be refined. They found, as Rundell (1998: 323) says, that "good corpus data is merely a prerequisite for better dictionaries; it does not in itself guarantee that good dictionaries will actually be produced". But as a starting point it is far ahead of the resources available when lexicographical efforts were begun in the 1970s.

As well as ease of access to dictionary data, the new computer system gave the editors a system for tracking the history of each record - who had edited it on what date and for what reason. This allowed them to manage the process by which an entry written by one editor might be reviewed by another and finally passed to the whole editorial committee as part of a final read before publication. The process of review is an essential part of the compilation of new material for the dictionary.

As part of this new way of managing the nitty-gritty of editorial work, the editors established a classification of the kinds of errors that occurred - typos, definition content, pronunciation, etc. - which they used to code each correction. The advantage of this was that it was possible to sort the corrections in their different categories, a process which facilitated proofing, and to identify quickly which part of the entry should be scrutinised. They initially identified a large set of correction types which were later reduced to a smaller and more manageable set with which editors could become thoroughly familiar.

This system allowed the incorporation of computer-generated safety features into the system - certain fields in each record had to be filled in before the computer would let go, so to speak, of corrected cards which were automatically identified as candidates for proof cycles for the editorial committee. The computer would not let data progress to the next edition before it was assured that the new material had been checked and approved. 


\section{The second edition (1991)}

The main feature of the second edition was the introduction of encyclopedic material. Again the editors drew on the base dictionary for world material, but this had to be updated, and the Australian material had to be developed with the help of consultants. There was a bias towards Australian material - about 5000 of the 20000 entries were Australian content. As John Bernard said in the Introduction to the second edition:

Our selection of encyclopedic entries caters specifically for the interests of Australians, and we see those interests as ranging intelligently across the whole world but having a special concern for all that is peculiarly Australian. For this reason the threshold for entry is rather lower for Australian names than for names from other countries, though of course many Australian names could get in over very high thresholds. There were broad principles for selection, such as that overseas cities were automatically included if their population exceeded 100 000; for Australian towns the threshold was just one thousand. But exceptions were allowed either way for places with some special claim for inclusion.

\section{Towards the third edition}

With the publication of the second edition in 1991 the Macquarie Dictionary moved into yet another computer system. This change was driven by the need to create MacquarieNet - an online source of Australian reference materials. The data needed to be in SGML (Standard Generalised Markup Language) so that it could be output both in typeset format and in HTML (Hypertext Markup Language) for the web site. The software chosen was SIM, also developed by RMIT University in Melbourne.

The new computer format meant that editors could now see the dictionary entries on screen as they would appear on the page, a luxury which before this had been reserved for final proofs. Until this format came into use, editors had worked with a coded output right up to final page proofs. They had learnt to read these codes, but understandably this was not as safe for editing purposes as the ultimate page format.

These final proofs had formerly come at the very end when publishing deadlines put editors under great pressure. Now they could see current work in its proper format at any time.

The new system produced its own pressure for a rewrite of the structural elements of all our dictionaries so that they would conform to one standard Document Type Definition (DTD) for programming purposes. This was a major undertaking which is now completed so that an interesting new set of possibilities opens up. 
Overall the advantages which editors have gained in the progress from a card system to a computer system are:

- the capacity to see the entry at any time as it would appear in the book,

- safety checks on data built into the system,

- the capacity to find any entry or any sets of entries with great speed and to impose various filters and categorisations on the data,

- an editing record for each entry built into the system,

- the capacity to transfer material from one database to another with comparative ease, and

- the capacity to link all the related entries in each dictionary so that a change in one entry can be carried through all the related entries in the other dictionaries with comparative ease.

Ultimately there will be just one database with all the information interlinked within it. The kind of power over the data that this will give the editors is something to look forward to.

\section{Features of the third edition (1997)}

The main feature of the third edition was the link that it established between Australian English and Australian literature, described in the preface:

One of the editorial policies, even for the first edition of this dictionary, was to assist readers of earlier Australian literature who would inevitably in their reading come upon words and phrases that are no longer current. Such words are listed and described in the dictionary, but in this third edition their meanings can also be illustrated by a selection of citations, each usually of a complete sentence, taken from a named work by a named author, with the date of first publication given as part of the entry.

Another feature of the third edition was its coverage of other language varieties of interest to Australians - Aboriginal English, and some of the Englishes of South-East Asia. The coverage of regionalisms in Australian English was revised by Dr Pauline Bryant on the basis of her research in this field.

The lack of usage notes in the dictionary had long been felt and it was decided that the third edition should remedy this. This was also in response to pressure from readers of the dictionary who sometimes did not read as much into coded labelling as the editors wanted them to do, or who raised questions such as whether the item should be included at all, which could not be answered from the material with which they were presented.

For example, why had the word youse been included? There were those who felt that this lowered the prestige of the dictionary. An editorial presence 
was needed to justify and explain, and that came with the usage note. The explanation made use of a labelling phrase (in non-standard use), a definition (plural form of you), an illustrative phrase (youse are all mad) and a dated citation from an Australian novel (Frost, the publican, desperately afraid of losing good customers, said to the four of us Englishmen: 'Can one of youse blokes play the piano?' The bush was full of pubs with pianos with no one able to play them. - HAROLD LEWIS, 1973.). All of these devices are used throughout the third edition, in order that the reader may see how, when, and why such a word might appear in a text or be used in an utterance.

\section{The future of the Macquarie Dictionary}

The basic set of dictionaries and thesauruses for Australian English requires constant updating and revision. Setting that aside, the editors have to ask themselves where else they might go and what else they might do. Within Australia there is a need for locally-produced ESL material and the first of a series of learner's dictionaries will be launched later this year. Because of the increased links with South-East Asia, the editors see the need for English language reference in that region that acknowledges the varieties of English that exist there. It is not possible to do the complete account, as has been done for Australian English, but at least the editors can do their best to produce research on these Englishes and accord them a status in the dictionary that they have not previously had.

The other new field that presents itself is electronic publishing. Macquarie Dictionary has established a site, MacquarieNet, that provides Australian reference to Australian schools. It is in its infancy at present but is gaining support as more and more schools come online.

Since work began in 1970, this dictionary enterprise has maintained objectives but has extensively changed in methods and range. Three of the original academic editors are still working on the project (Arthur Delbridge, John Bernard, David Blair), and two others, Pamela Peters (editor of The Cambridge Australian English Style Guide) and Colin Yallop (now the Editor-in-Chief), have joined more recently. When the first edition was published, Macquarie University agreed to the formation of a publishing company. The Macquarie Library Pty Ltd, to carry forward the publishing program. It is housed on the University campus, for close communication with University staff and services. The publishing editor of the Editorial Committee, Susan Butler, has been with the project since 1970 and has the role of Publisher of The Macquarie Library Pty Ltd. The senior editing staff of that company join with the Editorial Committee to form the text of each edition and ensure its accuracy and authenticity. The institutional support and public acceptance that it enjoys well and truly justify the aspirations of those who had the ambition to produce a truly national dictionary for its primary users, a privileged possession which some other major varieties of English had already long enjoyed. 


\section{References}

Bamhart, Clarence L. 1948. American College Dictionary. New York: Harper.

Bryant, Pauline. 1992. Regional Variation in the Lexicon of Australian English. Ph.D. thesis. Canberra: Australian National University.

Burchfield, Robert. 1982. Opening words. The Age, Melbourne, 1 March 1982, Monthly Review, 1011.

Butler, Susan (Ed.). 1981-1989. Macquarie Dictionary Society Newsletter 1(1)-5(3-4), Sydney.

Carstensen, B. 1984. A Bibliography of Writings on Varieties of English, 1965-1983. Viereck, Wolfgang, Edgar W. Schneider and Manfred Gorlach (Eds.). Varieties of English around the World. General Series. Vol. 3. Amsterdam/Philadelphia: Benjamins.

Clark, Manning. 1963. A Short History of Australia. Sydney: Tudor Distributors.

Delbridge, A. 1992. Lexicography in Australia. Lexikos 2: 63-72.

Delbridge, A. 1999. Standard Australian English. Pakir, A. and S.K. Gill (Eds.). World Englishes Vol. 18, No. 2: 259-270. London: Blackwell.

Delbridge, A., J.R.L. Bemard, D. Blair, W.S. Ramson and Susan Butler (Eds.). 1981. The Macquarie Dictionary. Sydney: The Macquarie Library.

Delbridge, A., J.R.L. Bemard, D. Blair, P. Peters and S. Butler (Eds.). 1991². The Macquarie Dictionary. Sydney: The Macquarie Library.

Delbridge, A., J.R.L. Bemard, D. Blair, S. Butler, P. Peters and C. Yallop (Eds.). 19973. The Macquarie Dictionary. Sydney: The Macquarie Library.

Dixon, R.M.W., W.S. Ramson and Mandy Thomas. 1990. Aboriginal Words in English: Their Origin and Meaning. Melboume: Oxford University Press.

Gove, Philip Babcock (Ed.-in-Chief). 1971. Webster's Third New International Dictionary. Springfield: G. \& C. Merriam.

Grayston, Graham (Ed.). 19945. Style Manual for Authors, Editors and Printers. Canberra: Australian Government Publishing Service.

Hanks, P. (Ed.). 1971. Encyclopedic World Dictionary. London: Hamlyn.

Mitchell, A.G. and A. Delbridge. 1965. The Speech of Australian Adolescents. Sydney: Angus \& Robertson.

Morris, E.E. 1898. A Dictionary of Austral English. London: Macmillan/Sydney: Sydney University Press, 1972.

Peters, Pamela. 1995. The Cambridge Australian English Style Guide. Cambridge: Cambridge University Press.

Peters, Pam (Ed.). 1992-1998. Australian Style. Sydney: Dictionary Research Centre, Macquarie University.

Ramson, W.S. 1988. The Australian National Dictionary. Melbourne: Oxford University Press.

Rundell, Michael. 1998. Recent Trends in English Pedagogical Lexicography. International Journal of Lexicography 11(4): 315-342.

Sinclair, J. (Ed.). 1987. Collins COBUILD English Language Dictionary. London: Collins.

Webby, Elizabeth. 1988. Writers, Printers, Readers: The Production of Australian Literature before 1855. Hergenham, L. (Ed.). 1988. The Penguin New Literary History of Australia: 113-125. Ringwood: Penguin Books Australia. 


\title{
Towards a Multilingual Dictionary of Academic Words*
}

\author{
Julia Read and Marguerite Ambrose, University of Pretoria, Pretoria, \\ Republic of South Africa
}

\begin{abstract}
Vocabulary is an essential component of study, of reading and writing skills. At present, English is the primary language of tertiary education in South Africa, and this puts students from other language backgrounds at a disadvantage. The proposed dictionary will therefore be aimed at second language English users who are entry level students at university. It will be in four languages: English, Afrikaans, Zulu and Sepedi. I.S.P. Nation and J. Coady have compiled an academic core vocabulary which tertiary students in all subject fields need to master in order to be able to encode and decode tertiary level texts, and this has been the basis for the planned dictionary. However, this list needs to be compared to and updated with material from a South African academic corpus. A preliminary comparative study has been conducted on the basis of authentic South African data, and a revised list has been created. The dictionary will not be subject-specific, but will deal with a general subtechnical vocabulary. Full definitions will be provided in all four languages, as well as translation equivalents, with English as the pivot language. Where a lexical gap occurs, translation equivalents will be coined with the help of the relevant experts. Thus the dictionary will also participate in much-needed corpus development of the African languages. It should become a valuable reference tool for both teacher and student.
\end{abstract}

Keywords: MULTILINGUAL, ACADEMIC CORE VOCABULARY, LEARNERS' DICTIONARY, READING SKILLS, CORPUS DEVELOPMENT, TRANSLATION EQUIVALENTS

\section{Opsomming: Op weg na 'n meertalige woordeboek van akademiese} woorde. Woordeskat vorm 'n essensiële deel van die leerproses, van lees- en skryfvaardighede. Tans is Engels die primêre taal van die tersiêre onderwys in Suid-Afrika, en dit benadeel studente met ander taalagtergronde. Die beplande woordeboek is derhalwe gerig op eerstejaanuniversiteitstudente wat Engels as tweede taal gebruik. Dit sal in vier tale wees: Engels, Afrikaans, Zulu en Sepedi. I.S.P. Nation en J. Coady het 'n akademiese kernwoordeskat saamgestel wat tersiêre studente in alle studierigtings behoort te ken om tekste op tersiêre vlak te enkodeer en te dekodeer, en dit het as basis vir die beplande woordeboek gedien. Hierdie lys moet egter vergelyk en opgedateer word met materiaal uit 'n Suid-Afrikaanse akademiese korpus. 'n Voorlopige vergelykende

4

This paper was read at the Third International Conference of the African Association for Lexicography, held at the Potchefstroom University for C.H.E., Potchefstroom, $29-30$ June 1998.

Lexikos 9 (AFRILEX-reeks/series 9: 1999): 172-187 
studie is gedoen op basis van outentieke Suid-Afrikaanse data, en 'n hersiene lys is opgestel. Die woordeboek sal nie vakspesifiek wees nie, maar gerig wees op die algemene, subtegniese woordeskat. Volledige definisies in al vier tale sal verskaf word, sowel as vertaalekwivalente, met Engels as die ankertaal. Waar leksikale gapings voorkom, sal vertaalekwivalente geskep word met die hulp van geskikte kundiges. Op hierdie manier sal die woordeboek bydra tot noodsaaklike korpusontwikkeling in die Afrikatale. Dit behoort ook ' $n$ waardevolle naslaangids vir sowel onderwysers as studente te wees.

Sleutelwoorde: MEERTALIG, AKADEMIESE KERNWOORDESKAT, LEERLINGWOORDEBOEK, LEESVAARDIGHEDE, KORPUSONTWIKKELING, VERTAALEKWTVALENTE

\section{Introduction}

In 1997 Peter Titlestad, Head of the Department of English, University of Pretoria, initiated a dictionary project with the aim of producing an explanatory multilingual dictionary of academic words. This dictionary is being produced in collaboration with Adelia Carstens (Department of Afrikaans, University of Pretoria) and Danie Prinsloo (Department of African Languages, University of Pretoria), with two research assistants, the authors of this article. The dictionary will be non-subject-specific, dealing rather with an academic core vocabulary, and could therefore be classified as a hybrid type (neither general nor scientific), which is intended to function as a teaching and tutoring aid for university students at entry level. The languages used will be English, Afrikaans, Sepedi, and Zulu, with English as the pivot language.

Today English is the main language used for tertiary education in South Africa and this can present a major problem to the increasing number of educationally disadvantaged university students for whom English is a second or even a third language. Even first language English students tend to find the jump from the vocabulary required to both read and produce texts at school level to that required at university level, a problem. One can therefore easily understand the difficulties experienced by non-mother-tongue speakers of English when faced with academic discourse for the first time. This dictionary is an attempt to provide such students access to a core academic vocabulary to partially bridge the gap between the language requirements at school and those at university.

Essential to this question of accessibility is vocabulary: in a study conducted by Paul Nation and James Coady it was found that of all the factors involved in the skill of reading, "vocabulary was the most important and had the strongest effect" (Nation and Coady 1990: 98). Furthermore, it was pointed out that "sentences are more readable if they contain words that are of high frequency in occurrence and that are shorter rather than longer". Other measures that influence readability are "the degree to which a word calls up other words quickly - association value - and concrete versus abstractness" (Nation and 
Coady 1990: 98). The average university text does not usually display these features. However, by helping students to understand and learn a core vocabulary of frequently occurring university words, we hope to help them with the difficult task of decoding tertiary level texts, and with the production of their own texts using this crucial vocabulary.

The focus here has been on entry-level (first and even second year) tertiary students for whom English is not the mother tongue. We have chosen to concentrate on the largest language groups for the other languages, namely Zulu, Afrikaans and Sepedi. These are the most significant in the region where the study is focused.

Of the 26991 students enrolled at the University of Pretoria in 1998, 15542 are Afrikaans-speaking, 4261 are English-speaking and 6741 speak languages other than Afrikaans and English.

Further justification for our use of Sepedi and Zulu is derived from the fact that of the top five languages in South Africa, Sepedi is the largest representative of the Sotho group of languages, while Zulu is the largest of the Nguni languages (see Appendix A).

Modifying Bergenholtz and Tarp's matrix (1995: 21) for the definition of dictionary-user types, we have defined the target users of this dictionary as students with incomplete encyclopaedic knowledge and low second-language proficiency. Encyclopaedic knowledge implies a knowledge of, in our case, general academic discourse. Therefore this dictionary can be classified as a learner's dictionary.

The target group is specifically South African, and therefore we have to deal with unique situations compared to those that helped British and other dictionary makers compile their learner's dictionaries. We do not seek to simply add to the number of excellent monolingual learner's dictionaries such as the Oxford Advanced Learner's Dictionary, the Longman Dictionary of Contemporary English or the Collins COBUILD English Language Dictionary, but instead we seek to confront our South African multilingual situation and produce useful definitions as well as translation equivalents.

The format that the dictionary will take, will be modelled on those of successful learner's dictionaries using definitions in very accessible language, clear symbols and a user-friendly referencing system. Layout will be a problem due to space constraints so it is imperative that each entry be clearly indicated, with possible colour-coding to highlight the different languages.

In fact, the macrostructure of the dictionary will be determined by its quadrilingual nature. Multilingual dictionaries run the risk of reaching excessive proportions. We hope to counteract this problem by using English as the language of access. Sepedi, Afrikaans and Zulu will be treated as target languages, but reverse lists will be provided in the back matter to serve as indices. In this way we will provide a means of access through all the languages and avoid complete unidirectionality. 


\section{Macrostructure}

Gabriele Stein says that "when dealing with a lexical knowledge base, one would be interested in the concepts with which learners should be familiar if they want to talk about all of those things that would be covered by the concepts underlying the actual English words" (1995: 25). For this reason we would like to include words with clear definitions to facilitate understanding and which will be crucial to respond correctly to examination papers, assignments and so on.

As a starting point for delimiting the macrostructure we have used I.S.P. Nation's Teaching and Learning Vocabulary: A University Word List, compiled at Victoria University, Wellington, New Zealand and consisting of the 811 most frequently used words in academic texts. One of the problems we encountered was with the contents of the list (see Appendix B). The list, going back to 1990, is slightly out-of-date, and certain words are of doubtful validity.

We will be supplementing and updating this list with terms used specifically in the contemporary South African academic context. To accomplish this, a study has been conducted by scanning authentic South African study material to form a computer database. With the assistance of Jeffrey Wagemakers, a visiting lexicology student from the Free University of Amsterdam in the Netherlands, we scanned study guides and examination papers from all the Faculties at the University of Pretoria. A computer program called Omnipage Pro was used, and the words were saved as ASCII files, which were retrieved into Microsoft Word. The resulting corpus consists of 92000 words.

Obviously this corpus is too small and too limited in breadth and depth. Firstly, one university cannot be regarded as representative of all South African universities, and secondly, examination papers and study guides alone are not sufficiently representative of academic discourse. Published academic literature such as text books and academic journals would have to be used as well. This corpus is an interim solution. We are only experimenting, using material from the University of Pretoria for tentative results.

The advantage of having a computer corpus is that we were able to compile frequency lists. We first extracted all words with a frequency of three and more. The result was our preliminary list which we then compared to the Nation list. The result of this comparative study is shown in Appendix C.

In this list we have usually included words from the Nation list which coincided with words in the list compiled in our study. The frequencies in the last column enable us to determine whether a particular word is possibly a valid addition to our final list. From both lists we aim to remove all words with nonacademic senses or which are subject-specific. Examples are:

bubbles and tractor which we removed from the Nation list, and chloride, auction, couplet, and court which we deleted from our list. 
Chloride, couplet and court are subject-specific, while auction, bubbles and tractor are of doubtful validity in general academic discourse.

If a word occurs in both lists, this is considered to be fairly strong justification to include it in our final list. However, the absence of a word from either one list or the other will not necessarily be seen as grounds for exclusion. All the same, neither frequency nor the fact that a word occurs in both lists will necessarily be seen as a sufficient reason if there appears to be no other justification for inclusion or exclusion. For example, anthropology and carbon were in both lists with a fairly high frequency. But carbon is subject-specific and anthropology is simply the name of a university subject.

In addition, comparing our list and the Nation list confirmed the existence of words with specific variant meanings in South African English academic usage. An example is motivate, which in South Africa is used in the sense "to support an argument", as illustrated in the following question taken from a first year Cultural History examination paper:

Is genealogical research merely a pleasant pastime or is it of value to the community at large? Motivate your answer.

As students we were unaware that this use of motivate was not standard English until one of our English lecturers pointed it out. The standard English senses of motivate given in the Concise Oxford Dictionary are:

1 supply a motive to; be the motive of. 2 cause (a person) to act in a particular way. 3 stimulate the interest of (a person in an activity)

Motivate had a frequency of 36 in the South African corpus, which is high for such a small corpus. Such examples of specifically South African senses will be marked accordingly. However, they are the exception rather than the rule, and we shall generally aim to maintain a certain standard of academic English, which Peter Titlestad believes exists as an important recognisable international form of English.

We hope that the end result of this work will be a sound academic core vocabulary, more up-to-date than the Nation list and with added authentic South African material.

\section{Microstructure}

Our English definitions are formulated by consulting three successful international advanced learner's dictionaries: the Oxford Advanced Learner's Dictionary, the Longman Dictionary of Contemporary English and the Collins COBUILD English Language Dictionary. The advantage of modelling definitions on these dictionaries is that they use a restricted defining vocabulary based on research into the needs of second-language English learners. Also apparent from the 
style of definition was the use of the pronoun you to refer to the third person instead of the impersonal (and these days somewhat formal) one, as well as the occasional use of the headword in definitions.

When defining there is, of course, the problem of "adequacy" in terms of linguistic correctness and "appropriateness" in terms of the needs and skills of the target group. Too much linguistic information might confuse the prospective user. There are, however, certain usages requiring explicit indications as to the typical syntactic and semantic contexts in which they occur, or to which they are restricted. While grammatical specifications are given in dictionaries, they are often in a coded form which even mother-tongue speakers find hard to follow. On the other hand, example sentences are more helpful in illustrating how the headword is used. Such examples of use will therefore be given, along with relevant collocations. This, in addition to the conventional grammatical information, will enable users to produce text as well as to translate it. This makes the dictionary more productive from a pedagogical point of view.

We are not simply providing translation equivalents as found in the South African Multi-Language Dictionary and Phrasebook, and the Concise Trilingual Dictionary Series. Although ambitious and fraught with pitfalls, we shall provide full definitions across all four languages. The challenge is to produce a quadrilingual dictionary which is comprehensively translatory and explanatory. Another problem exists in cases where one or more of the languages have more than one translation equivalent of a term. If the translation equivalents represent different polysemic distinctions then each of the two equivalents must be given with their own definitions. However, the less commonly used equivalent will, if possible, be given as a synonym, as with the Sepedi definition of contrast (see Appendix D).

In a subject-specific dictionary only one meaning of a term usually needs to be included. However, in general academic language terms are often polysemic and there is also the problem of homonyms. It would appear to be almost impossible to link different meaning distinctions in the different languages with one another. This is quite evident simply by glancing at the length of the definitions. Finer distinctions that exist in one language do not necessarily exist in another. If we look at the example of define there are three senses given for English, while in the Afrikaans and Sepedi definitions only one sense is given. In a bilingual dictionary there are set ways of dealing with this problem, but in a quadrilingual dictionary the situation is more complicated and challenging, and will require creative and innovative solutions.

Another serious hurdle to be confronted when compiling a South African multilingual dictionary is the occasional absence of word-for-word translation equivalents across languages. If a complete lexical gap should occur in one of the target languages (as is anticipated), a surrogate equivalent may be coined as an interim solution. Such a lexical item would be marked to indicate its nonlexicalised status. This borders on the corpus development of the previously marginalised African languages. This would involve close co-operation among 
a wide range of experts such as the Terminology Division of the National Language Service. Furthermore, it is a controversial and immense task. When more work has been done in this regard, the dictionary will have to be revised.

\section{Conclusion}

As Gabriele Stein (1995: 2) points out: "There is still a great and urgent need for developing adequate teaching materials to facilitate vocabulary expansion and differentiation." By developing a multilingual dictionary of academic words we will be paving the way towards helping students and tutors bridge the gap between the actual and the expected vocabulary required from a tertiary level student in a predominantly English and sometimes Afrikaans environment. The dictionary aims to provide students with a general knowledge basis of the "foreign language" - academic English. A good reference guide would lower the learning curve of the student and be a useful aid to lecturers.

This would be a definite starting-point for a task that needs to begin somewhere. There has been a lot of talk about such projects, and very little concrete action. Since this is a ground-breaking dictionary, its production will be an ongoing process. With the opportunities that desk-top publishing provides, we may be able to produce pilot versions to test sections of the dictionary with students before the final product is released. The primary aim is after all to produce a dictionary which will be a relevant and useful tool for its target users: students in a multilingual South Africa.

The last thing we wish to produce is yet another vague document which ignores all the glaring problems and explains words that have no practical relevance. Even if this dictionary in itself may seem limited in scope and may seem to be of little value to, say, a student of chemistry or engineering because it is non-subject-specific, we are aware that much is done at present to create such subject-specific dictionaries. Our goal lies elsewhere.

We aim to create a more general tool that will also advance the development of dictionary material in the African languages, making information more accessible to all.

\section{Reference List}

Allen, R.E. (Ed.). 1990. The Concise Oxford Dictionary of Current English. Oxford: Clarendon.

Bergenholtz, H. and S. Tarp. 1995. Manual of Specialised Lexicography. Amsterdam: John Benjamins.

Central Statistical Service. 1992. Population Census 1991: Report No. 03-01-06. Pretoria: Central Statistical Service.

Nation, I.S.P. 1990. Teaching and Learning Vocabulary: A University Word List. New York: Newbury House.

Nation, I.S.P. and J. Coady. 1988. Vocabulary and Reading. Carter, R. and M. McCarthy (Eds.). 1988. Vocabulary and Language Teaching: 97-110. Harlow: Longman. 
Schuring, G.K. 1990. Taalbeplanning vir 'n nuzwe Suid-Afrika. Pretoria: Human Sciences Research Council.

Stein, G. 1995. The Dictionary and the Language Learner. Keynote lecture at "English in Africa", Grahamstown, September 1995. 


\section{Appendix A}

South Africa: Number of Speakers and Degree of Language Knowledge (numbers in millions)

$\begin{array}{lccc}\text { Language } & \text { L1 Speakers } & \text { L2 Speakers } & \text { Total } \\ \text { Zulu } & 8.5 & 15.7 & 24.2 \\ \text { English } & 3.4 & 18.5 & 21.9 \\ \text { Xhosa } & 6.9 & 11.0 & 17.9 \\ \text { Afrikaans } & 6.2 & 16.5 & 22.7 \\ \text { Sepedi } & 3.4 & 9.1 & 12.5\end{array}$

(Statistics about L1 speakers from Schuring 1990; statistics about L2 speakers and total number of speakers from results of the 1991 National Census)

University of Pretoria: Language Profile 1998

$\begin{array}{lr}\text { Afrikaans } & 15542 \\ \text { English } & 4261 \\ \text { Other } & 6741\end{array}$

(Figures from UP Administration) 


\section{Appendix B}

\section{Teaching and Learning Vocabulary - Towards a University Word List: A-D (Nation 1990: 235-236)}

The numbers after the words group them according to frequency and range. So the words with 1 following them are in the most frequent group and have the widest range.

A

Abandon 3

Abnormal 6

Absorb 5

Abstract 5

Academic 6

Accelerate 2

Access 10

Accompany 6

Accomplish 3

Accumulate 11

Accurate 5

Achieve 2

Acid 9

Acquire 4

Adapt 3

Adequate 3

Adhere 8

Adjacent 2

Adjective 6

Adjust 3

Administer 4

Adolescent 7

Advocate 5

Adult 6

Aesthetic 4

Affect 2

Affiliate 7

Affluence 7

Aggregate 8

Aggression 8

Agita te 6

Aid 5

Alcohol 7

Align 8
Allege 4

Allocate 4

Allude 8

Ally 8

Alter 4

Alternative 1

Ambiguity 9

Amorphous 9

Analogy 4

Analyse 1

Angular 10

Annual 11

Anomaly 10

Anonymous 10

Anthropology 10

Apparatus 11

Appeal 6

Append 10

Appendix 10

Appraise 4

Appreciate 3

Approach 1

Appropriate 3

Approximate 2

Arbitrary 1

Area 3

Aristocrat 7

Arithmetic 11

Arouse 6

Ascribe 10

Aspect 6

Aspiration 10

Assemble 4

Assent 10

Assert 2
Assess 1

Asset 9

Assign 1

Assimilate 10

Assist 6

Assume 1

Assure 4

Astronomy 7

Atmosphere 4

Atom 4

Attach 11

Attain 6

Attitude 3

Attribute 4

Auspices 10

Authorise 2

Automatic 2

Avail 4

Averse 9

Aware 2

Awe 6

Axis 4

B

Battery 11

Benefit 6

Biology 5

Bomb 4

Bore 8

Breed 11

Bubble 11

Bulk 11

Bureaucracy 8

C

Calendar 11
Cancel 11

Capable 4

Capture 11

Carbon 9

Career 11

Catalogue 11

Category 5

Cater 8

Cease 4

Cell 7

Challenge 11

Channel 11

Chapter 2

Chemical 3

Circuit 11

Circulate 8

Circumstance 3

Civic 6

Clarify 6

Classic 3

Client 5

Clinic 10

Code 5

Coefficient 10

Cogent 10

Coincide 8

Collapse 7

Collide 6

Colloquial 7

Column 11

Comment 6

Commit 6

Commodity 7

Commune 3

Communicate 11 


$\begin{array}{llll}\text { Compel 11 } & \text { Construct 1 } & \text { Culture 4 } & \text { Deviate 3 } \\ \text { Compensate 1 } & \text { Construe 9 } & \text { Cumbersome 7 } & \text { Devise 1 } \\ \text { Competence 7 } & \text { Consult 1 } & \text { Currency 8 } & \text { Devote 2 } \\ \text { Compliment 9 } & \text { Consume 3 } & \text { Cycle 6 } & \text { Diagram 4 } \\ \text { Complex 1 } & \text { Contact 3 } & \text { Cylinder 11 } & \text { Diameter 11 } \\ \text { Complicate 2 } & \text { Contaminate 4 } & & \text { Dictate 5 } \\ \text { Comply 1 } & \text { Contemplate 6 } & \text { D } & \text { Diffuse 5 } \\ \text { Component 1 } & \text { Contend 6 } & \text { Data 1 } & \text { Digest 11 } \\ \text { Compound 5 } & \text { Context 1 } & \text { Debate 11 } & \text { Dimension 1 } \\ \text { Comprehend 2 } & \text { Contingent 6 } & \text { Decade 2 } & \text { Discern 8 } \\ \text { Comprise 10 } & \text { Continent 7 } & \text { Decimal 11 } & \text { Discourse 4 } \\ \text { Compulsion 10 } & \text { Contract 5 } & \text { Decline 6 } & \text { Discrete 3 } \\ \text { Compute 6 } & \text { Contradict 4 } & \text { Dedicate 4 } & \text { Dispense 10 } \\ \text { Conceive 2 } & \text { Contrary 5 } & \text { Defect 11 } & \text { Disperse 3 } \\ \text { Concentrate 2 } & \text { Contrast 2 } & \text { Defer 7 } & \text { Displace 9 } \\ \text { Concentric 7 } & \text { Contribute 2 } & \text { Deficient 3 } & \text { Dispose 3 } \\ \text { Concept 1 } & \text { Controversy 6 } & \text { Define 1 } & \text { Dispute 5 } \\ \text { Conclude 1 } & \text { Convene 3 } & \text { Definite 1 } & \text { Dissipate 8 } \\ \text { Condense 9 } & \text { Converge 10 } & \text { Deflect 10 } & \text { Dissolve 7 } \\ \text { Conduct 3 } & \text { Converse 6 } & \text { Degenerate 6 } & \text { Distinct 1 } \\ \text { Confer 7 } & \text { Convert 2 } & \text { Degrade 7 } & \text { Distort 2 } \\ \text { Configuration 7 } & \text { Cooperate 6 } & \text { Deliberate 10 } & \text { Distribute 4 } \\ \text { Confine 9 } & \text { Coordinate 3 } & \text { Democracy 7 } & \text { Diverge 9 } \\ \text { Conflict 3 } & \text { Corporate 7 } & \text { Demonstrate 2 } & \text { Diverse 4 } \\ \text { Conform 6 } & \text { Correlate 8 } & \text { Denominator 4 } & \text { Divine 7 } \\ \text { Confront 5 } & \text { Correspond 3 } & \text { Denote 1 } & \text { Doctrine 6 } \\ \text { Congress 7 } & \text { Create 2 } & \text { Dense 4 } & \text { Domestic 7 } \\ \text { Conjunction 6 } & \text { Credible 3 } & \text { Deny 5 } & \text { Dominate 4 } \\ \text { Consent 8 } & \text { Creditor 7 } & \text { Depress 7 } & \text { Drain 11 } \\ \text { Consequent 2 } & \text { Crisis 5 } & \text { Deprive 8 } & \text { Drama 3 } \\ \text { Conserve 7 } & \text { Criterion 1 } & \text { Derive 1 } & \text { Drastic 9 } \\ \text { Consist 1 } & \text { Critic 3 } & \text { Design 2 } & \text { Drug 8 } \\ \text { Console 6 } & \text { Crucial 2 } & \text { Detect 8 } & \text { Duration 5 } \\ \text { Constant 1 } & \text { Crystal 7 } & \text { Detriment 8 } & \text { Dynamic 3 } \\ \text { Constitute 4 } & & & \end{array}$




\section{Appendix C}

\begin{tabular}{|c|c|c|c|}
\hline & 占 & $\begin{array}{l}\bar{a} \\
\stackrel{a}{D}\end{array}$ & 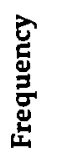 \\
\hline \multicolumn{4}{|c|}{$\mathbf{A}$} \\
\hline $\begin{array}{l}\text { ability } \\
\text { able }\end{array}$ & & $\begin{array}{l}x \\
x \\
\end{array}$ & $\begin{array}{r}18 \\
284 \\
\end{array}$ \\
\hline $\begin{array}{l}\text { abnormal } \\
\text { abnormalities }\end{array}$ & $x$ & $\begin{array}{l}x \\
x \\
\end{array}$ & $\begin{array}{r}4 \\
13 \\
\end{array}$ \\
\hline absence & & $x$ & 9 \\
\hline academic & $x$ & $x$ & 25 \\
\hline acceleration & $x$ & $x$ & 8 \\
\hline $\begin{array}{l}\text { accept } \\
\text { acceptable } \\
\text { acceptance }\end{array}$ & & $\begin{array}{l}x \\
x \\
x \\
\end{array}$ & $\begin{array}{r}8 \\
6 \\
17 \\
\end{array}$ \\
\hline $\begin{array}{l}\text { access } \\
\text { accessible }\end{array}$ & $x$ & $\begin{array}{l}x \\
x \\
\end{array}$ & $\begin{array}{l}9 \\
4\end{array}$ \\
\hline according & & $x$ & 27 \\
\hline account & & $x$ & 17 \\
\hline $\begin{array}{l}\text { accurate } \\
\text { accurately }\end{array}$ & $x$ & $\begin{array}{l}\mathrm{x} \\
\mathrm{x} \\
\end{array}$ & $\begin{array}{l}6 \\
4 \\
\end{array}$ \\
\hline $\begin{array}{l}\text { achieve } \\
\text { achievements }\end{array}$ & $x$ & $\begin{array}{r}x \\
x \\
\end{array}$ & $\begin{array}{r}10 \\
4 \\
\end{array}$ \\
\hline acid & $x$ & $x$ & $\overline{6}$ \\
\hline acknowledge & & $x$ & 4 \\
\hline acquaint & & $x$ & 5 \\
\hline $\begin{array}{l}\text { acquire } \\
\text { acquisition }\end{array}$ & $x$ & $\begin{array}{r}x \\
x \\
\end{array}$ & $\begin{array}{r}12 \\
7 \\
\end{array}$ \\
\hline act & & $x$ & 61 \\
\hline $\begin{array}{l}\text { action } \\
\text { active }\end{array}$ & & $\begin{array}{l}x \\
x \\
\end{array}$ & $\begin{array}{l}38 \\
11 \\
\end{array}$ \\
\hline actual & & $x$ & 9 \\
\hline $\begin{array}{l}\text { adapt } \\
\text { adaptation }\end{array}$ & $x$ & $x$ & 4 \\
\hline $\begin{array}{l}\text { addition } \\
\text { additional }\end{array}$ & & $\begin{array}{l}x \\
x \\
\end{array}$ & $\begin{array}{l}12 \\
20 \\
\end{array}$ \\
\hline adequate & $x$ & $x$ & 6 \\
\hline $\begin{array}{l}\text { administer } \\
\text { administration } \\
\text { administrative }\end{array}$ & $x$ & $\begin{array}{l}x \\
x \\
\end{array}$ & $\begin{array}{l}15 \\
18 \\
\end{array}$ \\
\hline $\begin{array}{l}\text { admission } \\
\text { admitted }\end{array}$ & & $\begin{array}{l}x \\
x \\
\end{array}$ & $\begin{array}{r}18 \\
5 \\
\end{array}$ \\
\hline advance & & $x$ & 11 \\
\hline advantage & & $x$ & 24 \\
\hline $\begin{array}{l}\text { advertising } \\
\text { advertisement }\end{array}$ & & $\begin{array}{l}x \\
x\end{array}$ & $\begin{array}{r}27 \\
8\end{array}$ \\
\hline advice & & $x$ & $\overline{5}$ \\
\hline
\end{tabular}

\begin{tabular}{|c|c|c|c|}
\hline advise & & $\mathbf{x}$ & 9 \\
\hline aesthetic & $x$ & $x$ & 6 \\
\hline affect & $x$ & $\mathbf{x}$ & 14 \\
\hline age & & $x$ & 29 \\
\hline agent & & $x$ & 14 \\
\hline $\begin{array}{l}\text { agree } \\
\text { agreement }\end{array}$ & & $\begin{array}{l}x \\
x\end{array}$ & $\begin{array}{l}22 \\
36\end{array}$ \\
\hline aim & & $x$ & 24 \\
\hline aims & & $x$ & 52 \\
\hline aimed & & $x$ & 5 \\
\hline alienation & & $\mathbf{x}$ & 14 \\
\hline allege & $x$ & $x$ & 4 \\
\hline $\begin{array}{l}\text { allocate } \\
\text { allocation }\end{array}$ & $x$ & $\mathbf{x}$ & 13 \\
\hline alternative & $x$ & $\mathbf{x}$ & 8 \\
\hline although & & $x$ & 11 \\
\hline analyse & $x$ & $x$ & 7 \\
\hline analyses & & $x$ & 6 \\
\hline analysis & & $\mathbf{x}$ & 27 \\
\hline analytical & & $\mathbf{x}$ & 6 \\
\hline antecedent & & $x$ & 6 \\
\hline anthology & & $x$ & 7 \\
\hline anthropology & $x$ & $x$ & 11 \\
\hline apparatus & $x$ & $x$ & 10 \\
\hline appear & & $\mathbf{x}$ & 14 \\
\hline applicable & & $x$ & 8 \\
\hline application & & $\mathrm{x}$ & 47 \\
\hline apply & & $x$ & 64 \\
\hline appointment & & $x$ & 25 \\
\hline $\begin{array}{l}\text { appreciate } \\
\text { appreciation }\end{array}$ & $x$ & $x$ & 6 \\
\hline approach & $x$ & $x$ & 18 \\
\hline approached & & $x$ & 6 \\
\hline approaches & & $x$ & 11 \\
\hline appropriate & $x$ & $x$ & 9 \\
\hline arbitration & & $x$ & 33 \\
\hline arc & & $x$ & 6 \\
\hline architect & & $x$ & 8 \\
\hline area & $x$ & $x$ & 21 \\
\hline argue & & $\mathbf{x}$ & 15 \\
\hline argument & & $x$ & 11 \\
\hline arranged & & $x$ & 13 \\
\hline arrangement & & $\mathrm{x}$ & 37 \\
\hline arrives & & $x$ & 6 \\
\hline art & & $x$ & 256 \\
\hline article & & $x$ & 12 \\
\hline aspects & $x$ & $\mathrm{x}$ & 45 \\
\hline assessment & $x$ & $x$ & 5 \\
\hline $\begin{array}{l}\text { assist } \\
\text { assistance }\end{array}$ & $x$ & $x$ & $\begin{array}{r}10 \\
9 \\
\end{array}$ \\
\hline associated & & $x$ & 8 \\
\hline
\end{tabular}




\begin{tabular}{|l|r|r|r|}
\hline assume & $\mathrm{x}$ & $\mathrm{x}$ & 10 \\
\hline atmosphere & $\mathrm{x}$ & $\mathrm{x}$ & 4 \\
\hline attitude & $\mathrm{x}$ & $\mathrm{x}$ & 11 \\
\hline $\begin{array}{l}\text { authorise } \\
\text { authority }\end{array}$ & $\mathrm{x}$ & & \\
\hline $\begin{array}{l}\text { automatic } \\
\text { automatically }\end{array}$ & $\mathrm{x}$ & & 11 \\
\hline average & & $\mathrm{x}$ & $\mathbf{1 1}$ \\
\hline $\begin{array}{l}\text { aware } \\
\text { awareness }\end{array}$ & $\mathrm{x}$ & $\mathrm{x}$ & 14 \\
\end{tabular}

B

\begin{tabular}{|l|r|r|r|}
\hline background & & x & 20 \\
\hline balance & & x & 43 \\
\hline barrier & & x & 28 \\
\hline base & & $x$ & 5 \\
based & & x & 25 \\
\hline basis & & x & 19 \\
\hline basic & & x & 45 \\
\hline behaviour & $\mathrm{x}$ & $\mathrm{x}$ & 10 \\
\hline benefit & $\mathrm{x}$ & $\mathrm{x}$ & 8 \\
\hline biological & & $\mathrm{x}$ & 17 \\
\hline body & & $\mathrm{x}$ & 14 \\
\hline brief & & $\mathrm{x}$ & 39 \\
briefly & & $\mathrm{x}$ & 5 \\
\hline broad & & $\mathrm{x}$ & 5 \\
broadly & &
\end{tabular}

C

\begin{tabular}{|l|r|r|r|}
\hline calculate & & $\mathrm{x}$ & 26 \\
calculation & & $\mathrm{x}$ & 10 \\
\hline calendar & $\mathrm{x}$ & $\mathrm{x}$ & 9 \\
\hline cancel & $\mathrm{x}$ & $\mathrm{x}$ & 9 \\
cancellation & & $\mathrm{x}$ & 31 \\
\hline capacity & & $\mathrm{x}$ & 50 \\
\hline capital & & $\mathrm{x}$ & 10 \\
\hline carbon & $\mathrm{x}$ & $\mathrm{x}$ & 10 \\
\hline careers & $\mathrm{x}$ & $\mathrm{x}$ & 14 \\
\hline case & & $\mathrm{x}$ & 79 \\
\hline categories & $\mathrm{x}$ & $\mathrm{x}$ & 13 \\
\hline cause & & $\mathrm{x}$ & 12 \\
causation & & $\mathrm{x}$ & 4 \\
\hline cell & $\mathrm{x}$ & $\mathrm{x}$ & 12 \\
\hline centre & & $\mathrm{x}$ & 13 \\
central & & $\mathrm{x}$ & 19 \\
\hline certain & & $\mathrm{x}$ & 29 \\
\hline change & & $\mathrm{x}$ & 27 \\
changed & & $\mathrm{x}$ & 5 \\
changes & & $\mathrm{x}$ & 20 \\
changing & & $\mathrm{x}$ & 5 \\
\hline channel & $\mathrm{x}$ & $\mathrm{x}$ & 4 \\
\hline
\end{tabular}

\begin{tabular}{|c|c|c|c|}
\hline chapter & $x$ & $x$ & 77 \\
\hline characteristic & & $x$ & 35 \\
\hline character & & $x$ & 28 \\
\hline characterisation & & $x$ & 5 \\
\hline check & & $x$ & 8 \\
\hline chemical & $x$ & $x$ & 6 \\
\hline choice & & $x$ & 37 \\
\hline choose & & $x$ & 16 \\
\hline chronological & & $x$ & 6 \\
\hline $\begin{array}{l}\text { circulate } \\
\text { circulation }\end{array}$ & $x$ & $\mathrm{x}$ & 14 \\
\hline circumstance & $x$ & $x$ & 13 \\
\hline claim & & $x$ & 15 \\
\hline claims & & $x$ & 11 \\
\hline claimed & & $x$ & 6 \\
\hline clarify & $x$ & $x$ & 4 \\
\hline class & & $\mathrm{x}$ & 178 \\
\hline $\begin{array}{l}\text { classic } \\
\text { classical }\end{array}$ & $x$ & $\mathbf{x}$ & 6 \\
\hline classification & & $x$ & 5 \\
\hline $\begin{array}{l}\text { clear } \\
\text { clearly }\end{array}$ & & & $\begin{array}{l}19 \\
13\end{array}$ \\
\hline close & & $\mathrm{x}$ & 13 \\
\hline code & $x$ & $x$ & 35 \\
\hline cognitive & & $x$ & 9 \\
\hline collection & & $x$ & $\overline{12}$ \\
\hline column & $\mathrm{x}$ & $\mathrm{x}$ & 13 \\
\hline combined & & $x$ & 6 \\
\hline commence & & $x$ & 7 \\
\hline comment & $x$ & $x$ & 17 \\
\hline commercial & & $x$ & 32 \\
\hline common & & $x$ & 23 \\
\hline $\begin{array}{l}\text { communicate } \\
\text { communication }\end{array}$ & $x$ & $\begin{array}{l}x \\
x\end{array}$ & $\begin{array}{r}5 \\
49 \\
\end{array}$ \\
\hline community & & $\mathbf{x}$ & 10 \\
\hline companion & & $x$ & $\overline{16}$ \\
\hline company & & $x$ & 23 \\
\hline compare & & $x$ & 15 \\
\hline $\begin{array}{l}\text { compensate } \\
\text { compensation }\end{array}$ & $\bar{x}$ & $\mathbf{x}$ & 6 \\
\hline competence & $\mathbf{x}$ & $\mathrm{x}$ & 5 \\
\hline competitive & & $x$ & 6 \\
\hline compile & & $x$ & 12 \\
\hline complete & & $x$ & 25 \\
\hline completion & & $\mathbf{x}$ & 32 \\
\hline complex & $x$ & $\mathrm{x}$ & 7 \\
\hline $\begin{array}{l}\text { complicate } \\
\text { complicated }\end{array}$ & $\mathrm{x}$ & $\mathbf{x}$ & 6 \\
\hline comply & $x$ & $x$ & 4 \\
\hline component & $x$ & $\mathrm{x}$ & 67 \\
\hline composition & & $x$ & 13 \\
\hline $\begin{array}{l}\text { comprehend } \\
\text { comprehension }\end{array}$ & $x$ & $\begin{array}{l}\mathrm{x} \\
\mathrm{x}\end{array}$ & $\begin{array}{r}13 \\
6 \\
\end{array}$ \\
\hline
\end{tabular}




\begin{tabular}{|c|c|c|c|}
\hline compulsory & & $x$ & 8 \\
\hline $\begin{array}{l}\text { concentrate } \\
\text { concentration }\end{array}$ & $x$ & $\begin{array}{l}x \\
x\end{array}$ & $\begin{array}{l}5 \\
5\end{array}$ \\
\hline concept & $x$ & $x$ & 86 \\
\hline $\begin{array}{l}\text { concern } \\
\text { concerned } \\
\text { concerning }\end{array}$ & & $\begin{array}{l}x \\
x \\
x\end{array}$ & $\begin{array}{r}7 \\
8 \\
24 \\
\end{array}$ \\
\hline concise & & $x$ & 13 \\
\hline $\begin{array}{l}\text { conclude } \\
\text { conclusion }\end{array}$ & $x$ & $\begin{array}{l}x \\
x \\
\end{array}$ & $\begin{array}{l}17 \\
44 \\
\end{array}$ \\
\hline concord & & $x$ & 5 \\
\hline concrete & & $x$ & 4 \\
\hline $\begin{array}{l}\text { condition } \\
\text { conditions } \\
\text { conditional } \\
\text { conditioning }\end{array}$ & & $\begin{array}{l}x \\
x \\
x \\
x \\
\end{array}$ & $\begin{array}{r}20 \\
14 \\
8 \\
8 \\
\end{array}$ \\
\hline conduct & $x$ & $x$ & 21 \\
\hline $\begin{array}{l}\text { confine } \\
\text { confined }\end{array}$ & $x$ & $\mathbf{x}$ & 4 \\
\hline conflict & $x$ & $x$ & 4 \\
\hline confusion & & $x$ & 4 \\
\hline connection & & $x$ & 15 \\
\hline $\begin{array}{l}\text { contract } \\
\text { contractual }\end{array}$ & $x$ & $\begin{array}{l}x \\
x\end{array}$ & $\begin{array}{r}292 \\
46 \\
\end{array}$ \\
\hline contrary & $x$ & $x$ & 8 \\
\hline contrast & $x$ & $x$ & 20 \\
\hline $\begin{array}{l}\text { contribute } \\
\text { contribution }\end{array}$ & $x$ & $\begin{array}{l}x \\
x\end{array}$ & $\begin{array}{r}7 \\
13 \\
\end{array}$ \\
\hline control & & $x$ & 27 \\
\hline conventions & & $x$ & 5 \\
\hline convey & & $x$ & 4 \\
\hline $\begin{array}{l}\text { cooperate } \\
\text { cooperation }\end{array}$ & $x$ & $x$ & 4 \\
\hline copy & & $x$ & 5 \\
\hline core & & $x$ & 5 \\
\hline corporate & $x$ & $x$ & 25 \\
\hline correct & & $x$ & 20 \\
\hline $\begin{array}{l}\text { correlate } \\
\text { correlation }\end{array}$ & $x$ & $x$ & 4 \\
\hline correspond & $x$ & $x$ & 4 \\
\hline cost & & $x$ & 37 \\
\hline course & & $x$ & 188 \\
\hline cover & & $x$ & 9 \\
\hline $\begin{array}{l}\text { create } \\
\text { creation }\end{array}$ & $x$ & $\begin{array}{l}x \\
x\end{array}$ & $\begin{array}{l}15 \\
15 \\
\end{array}$ \\
\hline $\begin{array}{l}\text { credit } \\
\text { creditor }\end{array}$ & $x$ & $\begin{array}{l}x \\
x\end{array}$ & $\begin{array}{l}17 \\
14 \\
\end{array}$ \\
\hline $\begin{array}{l}\text { critical } \\
\text { critically } \\
\text { criticism } \\
\text { critique } \\
\text { critic }\end{array}$ & $x$ & $\begin{array}{l}x \\
x \\
x \\
x \\
x\end{array}$ & $\begin{array}{r}44 \\
8 \\
41 \\
6 \\
5\end{array}$ \\
\hline cultural & & $x$ & 21 \\
\hline
\end{tabular}

\begin{tabular}{|l|r|r|r|} 
culture & $\mathrm{x}$ & $\mathrm{x}$ & 79 \\
\hline current & & $\mathrm{x}$ & 10 \\
\hline curve & & $\mathrm{x}$ & 10 \\
\hline custom & & $\mathrm{x}$ & 10 \\
\hline cycle & $\mathrm{x}$ & $\mathrm{x}$ & 5 \\
\hline
\end{tabular}

\section{D}

\begin{tabular}{|c|c|c|c|}
\hline data & $x$ & $x$ & 19 \\
\hline deal & & $x$ & 19 \\
\hline dealt & & $x$ & 16 \\
\hline debate & $x$ & $x$ & 25 \\
\hline decide & & $\bar{x}$ & 12 \\
\hline decision & & $x$ & 20 \\
\hline declaration & & $x$ & 6 \\
\hline decode & & $x$ & 12 \\
\hline decrease & & $x$ & 7 \\
\hline defect & $x$ & $x$ & 14 \\
\hline defence & & $x$ & 4 \\
\hline define & $x$ & $x$ & 79 \\
\hline definition & & $x$ & 44 \\
\hline degree & & $x$ & 28 \\
\hline delay & & $x$ & 4 \\
\hline deliver & & $\mathrm{x}$ & 14 \\
\hline delivery & & $x$ & 17 \\
\hline demands & & $x$ & 21 \\
\hline depth & & $x$ & 6 \\
\hline describe & & $x$ & 136 \\
\hline description & & $x$ & 13 \\
\hline design & $x$ & $x$ & 119 \\
\hline designed & & $x$ & 5 \\
\hline detail & & $x$ & 21 \\
\hline detailed & & $x$ & 22 \\
\hline details & & $x$ & 20 \\
\hline determination & & $x$ & 5 \\
\hline determine & & $x$ & 53 \\
\hline develop & & $\mathrm{x}$ & 41 \\
\hline developing & & $x$ & 8 \\
\hline development & & $x$ & 82 \\
\hline devices & & $x$ & 15 \\
\hline diagram & $x$ & $x$ & 10 \\
\hline dialogue & & $x$ & 4 \\
\hline difference & & $x$ & 34 \\
\hline different & & $x$ & 110 \\
\hline differentiate & & $x$ & 4 \\
\hline differs & & $x$ & 4 \\
\hline difficult & & $x$ & 6 \\
\hline difficulties & & $x$ & 5 \\
\hline diffuse & $x$ & & \\
\hline diffusion & & $x$ & 6 \\
\hline dimension & $x$ & $x$ & 4 \\
\hline direct & & $x$ & 9 \\
\hline directions & & $x$ & 7 \\
\hline
\end{tabular}


186 Julia Read and Marguerite Ambrose

\begin{tabular}{|l|r|r|r|}
\hline disadvantage & & $\mathbf{x}$ & 15 \\
\hline discipline & & $\mathbf{x}$ & 4 \\
\hline discourse & $\mathbf{x}$ & $\mathbf{x}$ & 7 \\
\hline discuss & & $\mathbf{x}$ & 379 \\
discussion & & $\mathbf{x}$ & 43 \\
\hline display & & $\mathbf{x}$ & 5 \\
\hline dispute & $\mathbf{x}$ & $\mathbf{x}$ & 5 \\
\hline distinct & $\mathrm{x}$ & & \\
distinction & & $\mathbf{x}$ & 8 \\
\hline distinguish & & $\mathbf{x}$ & 85 \\
\hline distribute & $\mathrm{x}$ & & \\
distribution & & $\mathbf{x}$ & 9 \\
\hline disturbances & & $\mathbf{x}$ & 11 \\
\hline
\end{tabular}

\begin{tabular}{|l|r|r|r|}
\hline division & & $\mathbf{x}$ & 6 \\
\hline doctors & & $\mathbf{x}$ & 7 \\
\hline doctrine & $\mathbf{x}$ & $\mathbf{x}$ & 7 \\
\hline documents & & $\mathrm{x}$ & 14 \\
\hline drain & $\mathrm{x}$ & & \\
drainage & & $\mathbf{x}$ & 7 \\
\hline drama & $\mathrm{x}$ & $\mathbf{x}$ & 25 \\
dramatic & & $\mathbf{x}$ & 13 \\
\hline draw & & $\mathrm{x}$ & 10 \\
\hline duration & $\mathrm{x}$ & $\mathbf{x}$ & 6 \\
during & & $\mathbf{x}$ & 90 \\
\hline duress & & $\mathrm{x}$ & 6 \\
\hline duty & & $\mathrm{x}$ & 18 \\
\hline
\end{tabular}




\section{Appendix D}

\section{Sample Definitions in English, Afrikaans and Sepedi}

\section{Template designed by Adelia Carstens}

English definitions by Marguerite Ambrose and Julia Read

Afrikaans definitions by Adelia Carstens

Sepedi definitions by Nelson Lekganyane

\section{CONTRAST}

contrast $1 \mathrm{~V}$. 1. to point out or consider the differences between two or more people or things. 2 . to show a clear difference when close together or when compared: John's actions contrasted sharply with his promises. * contrasting ADJ. very different in style, colour, etc: contrasting ideas, patterns etc.

contrast $2 \mathrm{~N}$. 1. a great difference between two or more people or things which is clear when you compare them. 2. a) the state of one thing being very different to something else b) a difference that is clearly seen when things are compared or put close together; to show that you are referring to a very different situation from the one you have just mentioned: by contrast; in contrast; in contrast to. c) a thing that shows such a difference: The way you sang tonight was quite a contrast to Monday's performance.

kontrasteer W. 1. teenoor mekaar afsteek: Die tradisionele kleredrag van die Tsongas kontrasteer sterk met dié van die Ndebeles. 2. teenoor iets anders stel: Kontrasteer die tydgees van die Barok tydperk met dié van die Rokoko.

kontras N. groot verskil tussen twee mense of dinge in 'n bepaalde konteks: Die kontras tussen lig en donker is baie groot in sy skilderye.

fapantsha V. go laetsa mokgwa wo e lego go re dilo di ka fapana ka gona mabapi le seemo goba sebopego sa tsona; = phapantsho: $A$ ke o leke go fapantsha dilo tse pedi tse di latelago : setulo le tafola.

phapano N. go laetsa mokgwa wo e lego go re dilo di ka fapana ka gona mabapi le seemo goba sebopego sa tsona; = pharologanyo: Go na le phaphano ye kgolo magareng ga go kitima le sepela.

\section{DEFINE}

define V. 1. to state precisely the meaning of something (words, terms, phrases etc.): define the biological term. 2. to state or describe the nature, extent, properties or essential qualities of something: The powers of a judge are defined by law; It's hard to define exactly how Dickens must have felt. 3. [usually passive] to show a line, shape, a feature, an outline etc. clearly: The outline of the man was clearly defined by the light behind him; Boundaries between farms must be clearly defined in order to avoid conflict. + definable ADJ.

definieer W. noukeurig omskryf: 'n begrip in die Sielkunde definieer; Definieer die begrip 'ideologie' in 'n paragraaf van veertig woorde.

hlalosa; hlatholla V. go ya hlaloso ya selo se se itsego gore motho a tle a kgone go tseba go re se bolela ka eng goba se mabapi le eng: Sebodu ke motho wa go tswafa. 


\title{
The Importance of a Business Plan when Planning a Lexicographical Project
}

\author{
Mariëtta Alberts, National Language Service, Department of Arts, Culture, \\ Science and Technology, Pretoria, Republic of South Africa
}

\begin{abstract}
This paper deals with the importance of a business plan when planning a lexicographical project. A business plan is an aspect of a lexicographical process most lexicographers would like to ignore. It is, however, an important step towards the establishment of a dictionary project. The compilation of a dictionary is a time-consuming process and a costly business, and proper planning is of the utmost importance, whether a dictionary project is undertaken by an individual or by a team of lexicographers. Therefore a business plan is the ideal tool for proper planning before embarking on a lexicographical project. It also gives stakeholders an indication of the scope of the envisaged lexicographical project. Financiers require a business plan to authorise the financing of a project, and this also applies to a lexicographical project. This paper deals with the importance of and reasons for a business plan. It also covers aspects such as drawing up a business plan as well as its contextual requirements.
\end{abstract}

Keywords: ACTION PLAN, BUSINESS PLAN, COLLABORATORS, CRITICAL SUCCESS FACTOR, EMPIRICAL SURVEY, END USER, FINANCIER, GOAL, HUMAN RESOURCES, KEY SERVICE, KEY UNCERTAINTY, KNOWLEDGE TRANSFER, LEXICOGRAPHICAL PRACTICE, LEXICOGRAPHY UNIT, MISSION, NEEDS ASSESSMENT, OBJECTIVE, OPPORTUNITY, ORGANISATIONAL STRUCTURE, RISK, SITUATION ANALYSIS, STAKEHOLDER, STRATEGY, VISION

Opsomming: Die belangrikheid van 'n sakeplan wanneer 'n leksikografiese projek beplan word. Hierdie artikel handel oor die belangrikheid van 'n sakeplan by die beplanning van ' $n$ leksikografieprojek. ' $n$ Sakeplan is ' $n$ aspek van die leksikografieproses wat liefs deur die meeste leksikograwe geignoreer sou wou word. Dit is egter ' $n$ belangrike stap in die totstandbrenging van ' $n$ leksikografieprojek. Die saamstel van ' $n$ woordeboek is ' $n$ tydrowende proses en duur saak en behoorlike beplanning is van die uiterste belang of die woordeboekprojek deur ' $n$ individu of deur ' $n$ span leksikograwe aangepak word. Derhalwe is ' $n$ sakeplan ' $n$ uitstekende hulpmiddel om behoorlike beplanning te doen voordat daar met 'n leksikografieprojek begin word. Dit gee aan belanghebbendes ' $n$ aanduiding van die omvang van die beoogde leksikografiese projek. Finansiers vereis ' $n$ sakeplan om die finansiering van 'n projek goed te keur en dit geld ook

This paper was read at the Fourth International Conference of the African Association for Lexicography, held at the University of Pretoria, Pretoria, 5-6 July 1999. 
vir 'n leksikografieprojek. Hierdie artikel handel oor die waarde van en rede vir 'n sakeplan. Dit dek ook aspekte soos die opstel van 'n sakeplan, sowel as die inhoudelike vereistes daarvan.

Sleutelwoorde: AKSIEPLAN, BEHOEFTEBEPALING, BELANGHEBBENDE, DOEL, DOELWIT, EINDGEBRUIKER, EMPIRIESE ONDERSOEK, FINANSIER, GELEENTHEID, INLIGTINGOORDRAG, KRITIEKE SUKSESFAKTOR, LEKSIKOGRAFIE-EENHEID, LEKSIKOGRAFIEPRAKTYK, MEDEWERKERS, MENSLIKE HULPBRON, MISSIE, ORGANISASIESTRUKTUUR, RISIKO, SAKEPLAN; SITUASIEANALISE, SLEUTELDIENS, SLEUTELVERANDERLIKE, STRATEGIE, VISIE

\section{Introduction}

A dictionary is a linguistic tool used for the development and preservation of languages. It may be regarded as an indispensable tool in the process of knowledge transfer at the targeted education or training levels and for promoting effective communication.

Dictionaries develop as a result of the specific language needs of language communities. The compilation of a dictionary can be a private enterprise or it can be state funded. The compilation of a dictionary is a time-consuming and costly process.

It is usually also the culmination of the professional contributions of a vast number of expert collaborators and (in the case of terminology) subject-field specialists, and the dedication and hard work of a number of language practitioners over a long period of time.

At present the lexicographical practice in South Africa is fragmented, since there are many established lexicographical interests financed either privately or by the Government. Different components originated from particular historical, cultural and organisational conditions, and consequently have a right to exist and are maintained for particular reasons.

All the stakeholders in the lexicographical practice, be it private lexicographers, publishers, language bureaux, academics, etc., need to plan their projects carefully. Many lexicographers decide to compile dictionaries based either on a feeling what they think to be a marketable product or on an idea which they believe to be viable. It is, however, very important to check the facts and to examine the viability of the idea by means of a needs assessment before embarking on the project.

To compile effective dictionaries it is important to undertake studies to assess the needs of dictionary users. The results of a needs assessment study will provide some of the required indications as to the viability of an envisaged project (Alberts 1992: 1). According to Wiegand (1987: 178, 179) an empirical study on dictionary usage and the needs of dictionary users will enhance the usability of envisaged dictionaries. Identified needs will lead to effective dictionaries and will therefore contribute towards eliminating obstacles in communication (Alberts 1992: 1). 
Given the above-mentioned facts and taking into account the expenses in time and money in establishing the relevant database for the compilation of a given dictionary, it is vital to plan a lexicographical project. The entire effort may be regarded a fruitless expenditure if in the end it transpires that the dictionary cannot be published due to certain constraints.

A business plan is the ideal tool for proper planning before embarking on a lexicographic project - whether done by an individual, a group of lexicographers, or a lexicographic unit. It provides the lexicographer with the opportunity to take a realistic, detached look at the process in its entirety. It also assists him/her to identify areas of strength and weakness; pinpoint needs and details one might overlook; and aids the lexicographer in determining how he/she can best achieve his/her goal to serve the target user group.

Perhaps the best way in which to show why a business plan is important, is to consider answers to questions such as:

- What exactly is a business plan?

- Why do you need one?

- When do you prepare one?

- How do you prepare one?

- Who has to prepare it?

\section{What is a business plan?}

A business plan is a detailed action programme outlining every conceivable aspect of your proposed lexicographical venture. It is a comprehensive, selfexplanatory plan of

\section{- what you intend doing, \\ - how you intend doing it, \\ - when you intend doing it, \\ - where you intend doing it, and \\ - why you believe your idea is viable.}

It is in essence a structured guideline to achieving your goals (cf. Morobe 1999: 42).

The main purpose of a business plan is to demonstrate to the stakeholders that proper advance planning has been done. There can be no fixed format for a business plan. The format adopted depends on the nature of the endeavour, the nature of the institution, the needs of the stakeholders and target users, as well as other factors, e.g. regulatory requirements that apply to some institutions. The exact format is therefore dependent on the above purpose, taking into account the factors mentioned. The guidelines given should be adopted to suit the lexicographical project's unique circumstances. 


\section{Why do you need a business plan?}

There are a number of good reasons for preparing a business plan. Amongst others, the following can be cited:

- sourcing finance: financial institutions require a business plan to authorise finance;

- feasibility: because a business plan requires the lexicographer to look at every aspect of the lexicographical process, it enables him/her to assess the feasibility of the project proposal;

- sourcing new ideas: by examining all the different aspects of the lexicographical process, other more profitable ideas may be discovered which may also be exploited;

- problems: a business plan enables the lexicographer to take cognisance of envisaged problems and to try to deal with them before engaging in the project;

- staff and technological needs: it helps to determine how many lexicographers or support personnel might be needed and to identify the need for technological assistance in the form of computer equipment (e.g. hardware), programs (e.g. software), etc.;

- managing the lexicographical process: it also acts as a strategic plan for the governing body by setting out a plan of action and estimating financial requirements which can later be used to manage the lexicographical process.

There is an old saying: "If you don't know where you are going, any road will take you there." In crafting sensible lexicographical strategies, you should know where you may end up, and have a good map to get there. A lexicographical project is at best a tiring adventure demanding a lot of time and patience. A business plan therefore serves as a kind of road map: as every traveller knows, a journey is a lot less risky when you have direction.

\section{When do you need a business plan?}

A business plan is the lexicographer's principal means of communicating his/her ideas to providers of capital and to partners or publishers to invest time and money in the lexicographical project. It often becomes the basis of an application when seeking financing for the project (cf. Morobe 1999: 42).

\section{Who has to prepare the business plan?}

The person with the executive responsibility in the lexicographical process (the project manager) should prepare the business plan. The project manager 
should be assisted with this task by a project team (i.e. the lexicographer(s) who will carry out the business plan). The financial side (e.g. balance sheet, income statement and cash flow forecasts) may require the services of an accountant. However, the essence of the plan should be drawn up by the project manager and the project team.

\section{The importance of a business plan}

According to Morobe (1999: 42) the importance of planning cannot be overemphasised. To maximise the effectiveness of business planning, it should be preceded by strategic planning related to the needs assessment. The business plan need not contain full details of the outcome of strategic planning, only enough to enable the reader to understand the business plan properly.

During the preparatory stages of any prospective lexicographical project it is wise to spend more time than the lexicographers might deem necessary to formulate the the business plan. This is important for the following reasons:

- it ensures that the project team arrange their thoughts in a logical order;

- it assists the project team in identifying and formulating objectives;

- it helps the project team to develop strategies to meet those objectives;

- it helps them to provide a structure to the lexicographical project by defining activities and responsibilities;

- it forces the project team to simulate reality and anticipate pitfalls;

- it serves as a working action plan or guideline when the lexicographical project is up and running;

- it is an essential aid when applying for financial assistance or when marketing the envisaged end product to a potential publisher; and

- it builds team spirit within the project team.

\section{The business plan as a financial tool}

Lexicographers need a business plan to obtain financial assistance, and for this reason the business plan must provide information required by others to evaluate the envisaged lexicographical project. A thorough plan becomes a financing proposal that will meet the requirements of most investors, lenders or publishers.

There are various kinds of financiers which may be approached by a lexicographer. Private funds may, as a first option, be raised by tapping one's own (or the lexicography unit's own) financial resources. Other options may include raising money from trusts, banks or other financing houses. Funds or grants may also be obtained from sources such as government departments, or from a specific language body such as the Pan South African Language Board. Most 
financiers will only provide money if the business plan inspires confidence with regard to a secure and profitable future. One should bear in mind that financiers do not think about the envisaged lexicographical project in the way the project leader and project team do. They have not been researching the envisaged project for several months and are seeing the proposal on paper for the first time.

When lexicographers need a business plan, they already think about the funds required to start the venture. They not only need funds, but also face the frustration of being at the back of the line for conventional lending resources. Large lenders do not back non-profitable business such as dictionary projects, and lexicographers have neither the time nor the financial expertise to find the right sources or to package their project in a manner to persuade lenders to accommodate them. Whatever kind of lender the lexicographer finally finds, he/she will have to present a proper business plan.

\section{How do you prepare a business plan?}

A business plan should start off with a mission statement. This is a short, clear, precise statement of the reason for the lexicographical project. It is intended to focus the reader's mind sharply on the purpose of the project. The mission should be phrased in such a way that all employees (project leader, lexicographers, etc.) can continuously test if and how their activities contribute towards fulfilling the mission.

The business plan need not describe goals and strategies in detail. That belongs in the strategic plan. The compilers of the business plan may however wish to include abridged details in order to make the chosen organisational structure and objectives comprehensible.

A situational analysis will provide the reader with insight into the current situation that necessitates the compilation of the planned dictionary.

A brief description of the various organisational segments and the function of each should be given. The design of the organisational structure should be based on a strategic planning exercise. In such an exercise the project team determines what goals it should pursue to fulfil its mission. Then the team decides on the strategies it should adopt to achieve these goals. Having determined goals and strategies, it becomes possible to determine an organisational structure such as divisions or sections required to perform various tasks relating to the project as well as their interrelationships and functions.

Where appropriate, projections of key variables that were used to do the business planning should be given to clarify the rationale behind the business plan.

A good business plan covers the following key areas: people, opportunity, context, risk and reward. 


\subsection{People}

This aspect of the business plan refers to the men and women starting and running the lexicographical project as well as the outside parties providing information, key services or resources for it.

The project leader needs to ask him-/herself a number of questions regarding the people involved, and these include:

- Where are they from?

- What experience do they have directly relevant to the opportunity?

- What expertise, skills, knowledge and abilities do they have?

- How committed are they to this venture?

- How realistic are they about the venture's chances of success and the tribulations?

- Who are the end users: scholars, students, a subject community or the general public?

- Who are the stakeholders?

- Who are the collaborators?

\subsection{Opportunity}

This is a profile of the project itself, what it will produce and for whom (known as the users group), whether it can grow and how fast, what its economics are, and who and what stands in the way of success.

One needs to state the mission, vision and goal of the project. An analysis of the present situation and the critical factors influencing the project can be given, with an outline of the strategies envisaged to obtain the set goals. Key uncertainties should be mentioned. The organisational structure with an indication of the present or approved staff complement as well as an indication of an extended staff complement should be given. One should also mention the human resources plan in order to accommodate all aspects of the envisaged project.

Questions that need to be asked regarding the opportunity include:

- What is the mission, vision and goal of the project?

- What is the present situation that will influence the project?

- What are the strategies envisaged to obtain the set goals?

- What organisational structure is needed?

- What key variables are projected?

- What are the objectives of the project?

- What are the critical success factors?

- What key uncertainties can be identified?

- What action plans must be introduced?

- What are the milestones to be specified? 
- Will the human resources be able to conduct the project?

- Does the market actually allow you to make a profit from this lexicographical project?

- Who is the user group for the new lexicographical project?

- At how much will the product or service resulting from the product (e.g. telephone enquiring service) be priced?

- How much will it cost to produce and deliver the lexicographical product or service?

- How do you put a monetary value to the product and service?

- Does the user pay cash or on credit?

- Who are the current competitors?

The literature on business planning is inconsistent regarding the meanings assigned to the terms used in this paper. One often finds that terms such as "goals", "objectives" and "targets", for example, are used interchangeably. For the purpose of describing the required contents of a business plan, they are given specific meanings in this paper.

A goal is a description of a state of affairs towards which the project team strives. It should naturally be as specific as possible, but need not be fully quantified.

An objective on the other hand should be quantified as closely as possible.

Having determined a goal, further detailed analysis and planning are needed to arrive at objectives. In the process certain end goals have to be broken down into sets of supporting goals; objectives cannot be quantified unless broken down into subobjectives, etc. The first set of goals can cascade down through multiple tiers to a set of detailed objectives that have to be reached to ultimately achieve the goals. These objectives need to be clearly stated in the business plan.

The factors that are considered to be critical for the successful execution of the business plan should be stated. That will enable the outside agencies (financiers, publishers, etc.) to form a better impression of the support they should attempt to provide to ensure success.

Any key uncertainties which can seriously hamper the execution of the business plan should be stated.

Action plans associated with each objective should be given, stating important target dates and responsibilities. Under certain circumstances it is deemed necessary to organise the action needed to meet objectives into projects rather than simply giving an organisational segment the responsibility for meeting the objective. A project is normally initiated to meet a specific objective, after which it is closed. Unless they are negligible in scope and budget, 
projects should be described in the business plan. The objective, main action steps and budget should, among others be given.

The process of compiling a dictionary is a time-consuming exercise. Certain objectives may only be reached within years. For them the business plan should specify milestones with target dates which should be reached in the time-span covered in the business plan.

The business plan should state all sources of income and the amounts expected from each. Estimated expenditure, broken down into an appropriate list of items should also be included. Current and capital expenditure should be shown separately. A projected balance sheet for the end of the financial year should be given. A budgeted cash flow with estimated payments. for each month of the financial year should also be included in the business plan.

\subsection{Context}

This includes the big picture - the usual environment, interest rates, demographic trends, political influences, inflation, and the like - factors that inevitably change but cannot be controlled by the lexicographer.

Questions that may be asked include:

- How do the macro- and market environments relating to lexicography hinder or promote the venture?

- How will changes in the lexicographical environment impact on the venture?

- What can the project leader and project team do if the environment should become unfavourable?

\subsection{Risk and reward}

This refers to an assessment of everything that can go wrong and go right, and an outline of how the project team can respond.

- What is the risk and how will it be managed?

- What rewards will the project deliver and to whom, when and how much?

\section{Financial forecasts}

A comprehensive outline of the financial plan and strategy of the project is often the most difficult aspect for most lexicographers. The essence lies in converting operational activities into money. For this the lexicographer needs to compile an estimated balance sheet, income statements and cash flow statements. These figures will reflect the key drivers of the project's success or fail- 
ure. The figures will also highlight the break-even level and the point at which cash flow turns positive. The services of an accountant may be sought for this aspect - especially if it is a major lexicographical project undertaken by for instance a lexicographical unit.

\section{Conclusion}

The compilation of a dictionary is an economical activity. A dictionary project needs to adhere to the same basic business principles as any other business venture if it aims to be a viable business proposition. Institutions which are serious in rendering a constructive contribution to reconciliation and nation building in South Africa might aim to give financial support to different dictionary projects in South Africa. However, before financing any dictionary project they will need proof of proper planning and management of such projects. A business plan can provide such proof.

\section{Note}

Dr Mariëtta Alberts was responsible for the drafting of new legislation to establish national lexicographical (dictionary) units for all the official languages (1995-1996). The Bill was ratified in June 1996. The Draft Bill was later incorporated into the revised PANSALB Act as regulations concerning the establishment of national lexicographical units.

\section{Bibliography}

Alberts, Mariëtta. 1992. Behoeftebepaling in die leksikografie. Lexikos 2: 1-27.

Morobe, David. 1999. The importance of your business plan. People Dynamics 17(3): 42-44.

Wiegand, H.E. 1987. Zur handlungstheoretischen Grundlegung der Wörterbuchbenutzungsforschung. Kǔera, A., A. Rey, H.E. Wiegand and L. Zgusta (Eds.). 1987. International Annual for Lexicography: 178-227. Tübingen: Max Niemeyer. 


\section{Planning and Management - the Most Neglected Activities in Lexicography}

D.J. van Schalkwyk, Bureau of the Woordeboek van die Afrikaanse Taal, Stellenbosch, Republic of South Africa

Abstract: Lexicography has a long history of ineffective planning and inefficient management. This article applies the methods of general planning and management to the planning and management of a lexicographic unit.

Keywords: PLANNING, MANAGEMENT, MISSION STATEMENT, STRATEGIC FOCUS AREAS, PERFORMANCE AREAS, SITUATIONAL DESCRIPTION, INTERNAL ENVIRONMENT, EXTERNAL ENVIRONMENT, ENVIRONMENTAL ANALYSIS, RESTRICTING FACTORS, SUPPORTING FACTORS, ENVIRONMENTAL TENDENCIES, SCENARIO, FUTURE STRATEGIC POSITION, GOALS, ACTION PLAN, PRODUCTION MANAGEMENT, MANAGEMENT SYSTEM.

Opsomming: Beplanning en bestuur - die mees verwaarloosde aktiwiteite in die leksikografie. Die leksikografie het ' $n$ lang geskiedenis van oneffektiewe beplanning en ondoeltreffende bestuur. In hierdie artikel word die metodiek van algemene beplanning en bestuur toegepas op die beplanning en bestuur van 'n leksikografiese eenheid.

Sleutelwoorde: BEPLANNING, BESTUUR, MISSIESTELLING, STRATEGIESE FOKUSAREAS, PRESTASIEAREAS, SITUASIEBESKRYWING, INTERNE OMGEWING, EKSTERNE OMGEWING, OMGEWINGSANALISE, BEPERKENDE FAKTORE, ONDERSTEUNENDE FAKTORE, OMGEWINGSTENDENSE, SCENARIO, TOEKOMSTIGE STRATEGIESE POSISIE, DOELSTELLINGS, PLAN VAN AKSIE, PRODUKSIEBESTUUR, BESTUURSTELSEL.

\section{Introduction}

When one considers the themes of papers delivered at national and international lexicographic conferences and congresses over the past decade, it is apparent that the planning and management of lexicographic projects is a theme which does not often arise. Visits to lexicographic projects confirm that planning and management are usually not very high on their agendas. The answer to a question such as: How can the work at a lexicographic project be accelerated?, is usually sought in areas other than in effective planning and management. 
Zgusta's (1971: 348) statement: "I certainly do not know all lexicographic projects past and present; but of those I know not a single one was finished in the time and for the money originally planned", reveals a common shortcoming by lexicographic projects to plan their finances and time. A lack of planning by lexicographers and publishers is also confirmed by Landau (1984: 229): "Usually the publisher is ignorant as to what's involved in preparing a dictionary, and the lexicographer is quite irresponsibly optimistic." Both problems can be solved by good planning and management.

\section{What is planning?}

Kroon et al. (1994: 125) states: "Planning can be defined as the management function that encompasses the purposeful consideration of the future objectives of an enterprise or part thereof, the means and activities involved and the drafting and implementing of a plan to make the efficient achievement of the objectives possible."

Planning is important for the following reasons (cf. Kroon et al. $1994: 127)$ :

- Planning helps to adapt to change and to reduce uncertainty,

- Planning focuses the enterprise's attention on its objectives,

- Planning improves performance and makes financial control possible,

- Planning guides managers' efforts,

- Planning is a prerequisite for control, and

- Planning ensures co-ordinated actions.

\section{What is strategic planning?}

Strategic planning is "the continuous long-term planning process of especially top and middle management to continuously achieve the enterprise's goals by developing and implementing a suitable plan amidst environmental change" (Kroon et al. 1994: 169).

Strategic planning is an ongoing process. It is never completed, but should always be brought in line with changing demands facing the unit.

Although the responsibility for strategic planning lies with top and middle management, it is a good strategy to periodically involve the entire establishment in this task. This fosters a democratic spirit and focuses all those involved on the goals of the establishment.

\section{A framework for strategic planning}

Strategic planning in general, and also with regard to lexicographic units, may be done in accordance with the following framework: 
(a) Mission statement

(b) Strategic focus areas or performance areas

(c) A historical overview

(d) Situational description

- The internal environment

- The external environment

(e) Environmental analysis

- Restrictive factors (weak points) in the internal environment

- Supportive factors (strong points) in the internal environment

(f) Environmental tendencies

- Restrictive factors (threats) in the external environment

- Supportive factors (opportunities) in the external environment

(g) Scenarios

(h) Assumptions regarding the future strategic position of the unit

(i) Goals

- Long-term goals

- Medium-term goals

- Short-term goals or strategic objectives

(j) Plan of action

It is self-evident that this framework may, with slight modifications, be utilized to plan a new as well as an existing lexicographic unit. This article will concentrate on the planning or replanning of an existing lexicographic unit. The role of each of the above-mentioned points in the planning process will briefly be discussed. Data from the strategic planning of the Bureau of the Woordeboek van die Afrikaanse Taal (WAT) are used in one illustrative case.

\section{Strategic planning of a lexicographic unit}

\subsection{Mission statement}

There is a reason for the existence of each lexicographic unit. This reason should find expression in the mission. The mission should also indicate the functions to be carried out by the unit. In the mission of the unit the endeavours of those involved and the task of the unit are embodied. The direction in which the unit wishes to go also needs to be clear from the mission.

An important question for a business enterprise is: What is your business? This question should be answered by the mission. The direction in which a lexicographic unit wishes to go in the long term is stated in the mission. The mission then guides the activities of the unit.

The mission of the Bureau of the WAT is to serve the Afrikaans language and language user as well as lexicography in general.

The following tasks result from this mission: 
(a) to continue with the compilation of the WAT, to complete it as soon as possible, and from time to time to improve the dictionary by

(i) the uninterrupted, representative and comprehensive collection, arrangement and storage in a lexicographically workable form of the vocabulary of the Afrikaans language in all its variations; and

(ii) the editing of the collected material according to scientifically established lexicographic principles in the form of an authoritative, userfriendly, synchronically explanatory dictionary in consecutive volumes;

(b) to grant controlled access to the language material and sources of the Bureau to bona fide researchers and to answer linguistic enquiries;

(c) to endeavour to establish appropriate lexicographic products for Afrikaans, but also for the other languages of South Africa, with the assistance of external authors;

(d) to produce the WAT and these satellite publications cost-effectively;

(e) to market these products dynamically and economically;

(f) to act as a growth point and stimulus for lexicographic activities and metalexicographic thought;

(g) to liaise with South African and foreign lexicographic and linguistic institutions with a view to exchanging lexicographic knowledge, information and publications;

(h) to contribute to lexicographic theory and practice in the form of scientific publications;

(i) to assist in raising the general level of lexicography, especially in Africa, through co-operation with external dictionary projects;

(j) to play an active role in the rectification of inequalities on the terrain of lexicography through training and the creation of jobs;

(k) to contribute to the establishment and development of South African lexicography in support of the aims of the Pan South African Language Board; and

(l) to strive for need-directedness, quality and a unity of character in its activities and products.

\subsection{Strategic focus areas or performance areas}

Two important questions which should always be asked and answered at a lexicographic unit, are

(a) Are the right things being done? and

(b) Are the right things being done right?

A third question which can be added, is 
(c) Are the right things being done right at the right time?

Answering the first question directs the unit towards its focus or performance areas. The second question concerns, inter alia, those norms applicable to a unit, and the third question applies to target dates.

The mission of a unit guides it towards the identification of its focus areas. It is with respect to these focus areas that a unit should perform if it wishes to carry out its mission.

If a unit does not clearly identify all its focus areas, some of its responsibilities will be neglected, and if non-focus areas are added, unnecessary work will be done. Both these approaches will impact negatively on a unit.

The following areas, or at least some of them, form the focus areas of every lexicographic unit:

- lexicographic needs assessment;

- planning of the dictionary;

- collection of language material;

- editorial treatment of the material;

- layout, printing and binding of the dictionary(-ies);

- marketing;

- research;

- personnel;

- finances;

- support services, such as information and computer services; and

- planning and management of the lexicographic unit.

Each of these areas requires specialized knowledge as well as skills to do detailed planning.

\subsection{An historical overview}

The successes and failures of a unit serves as a vital input during the unit's strategic planning. Therefore it is a good strategy to keep updating the history of the unit. It is important for a unit to build on the successes achieved and not to repeat the mistakes.

The availability and knowledge of the history of a unit, also its contemporary history, enable new colleagues to adapt more quickly to their work environment.

It is very difficult, if not impossible, to carry a unit to new heights by planning and management if its past is completely ignored. 


\subsection{Situational description}

It is important for good strategic planning to have a clear insight into the unit's situation at the time of the planning exercise. This situation is determined by the internal as well as the external environment.

The internal environment of a unit encompasses everything under its control. All other factors which may influence the unit, but over which it has no control, is considered to be part of the external environment, for example the political and economic conditions of a country.

The state of each focus area in the internal environment as well as the influence of the external environment on the focus areas should be taken into account during the situational description.

The influence of changing conditions on the internal and external situation needs to be constantly monitored by management so that their possible effects on the planning of the unit do not go by unnoticed. The unit should be in a state of symbiosis with its internal and external environment, and the planning of the unit should maintain this symbiosis.

\subsection{Environmental analysis}

The welfare of a lexicographic unit depends to a large extent on management's ability to identify the strong and weak points in the internal environment and to act upon them.

The weak points or restrictive factors of a unit increase its vulnerability in a changing environment. Planning should aim to decrease or remove the effects of these weak points as far as possible. It should be management's strategy to transform weak points into strong points.

The strong points or supportive factors provide the unit with the opportunity to act proactively in order to ensure success. A unit's strong points form the basis on which it can confidently liaise with the outside world.

Those involved with a unit should not be afraid to identify its weak points during the analysis of its environment, since no recovery is possible unless an organization can identify its weaknesses. Involved parties should also, however, not be obsessed with the weak points of a unit, as such an obsession may eventually paralyse the unit completely.

Lexicographic units are very much like people, they are never so weak that they do not also have strong points.

\subsection{Environmental tendencies}

Tendencies in the external environment of a unit may pose threats or present opportunities to it. Each potential threat or restrictive factor should be identified, 
analysed and handled. In this way risks to which the unit may be exposed, are decreased.

To a large extent, the success of a unit depends on the utilization of the opportunities or supportive factors in the external environment. A good grasp of the opportunities and the correct utilization thereof may contribute not only to the neutralization of threats, but also to increase the effectiveness of the unit.

The influence of threats and opportunities in the external environment on each focus area should always be taken into consideration. Here too, the strategy should be to transform threats into opportunities. Upon the analysis of a threat, it is often found that the correct utilization thereof holds a valuable opportunity. For example, political circumstances in a country may apply pressure on the future possibilities of a language, but such pressure may in turn stimulate the marketing of dictionary products.

\subsection{Scenarios}

Since all decisions have implications for the future of a unit, it is very important that those involved develop a feeling for the future within which the unit needs to function. The aim of a scenario is to construct the future within which the unit needs to fulfil its role as accurately as possible. During such a construction of this future, the past and present situation as well as linguistic and lexicographic tendencies may serve as a valuable input. From such a scenario, the unit may obtain an indication of the challenges awaiting it, as well as the effects which current decisions may have in the future. A scenario is the outcome of a reflection on the future and the influence which the future may have on the unit. A scenario enables the decision-makers of the unit to evaluate anticipated consequences of decisions in a critical manner.

The more turbulent the external environment becomes, the more difficult it is to develop a scenario which maintains its validity over a longer period of time. In turbulent circumstances a scenario may be developed for a shorter period of time, e.g. three or five years. It then needs to be evaluated on an ongoing basis with the aim of adapting or revising it.

It may be a good exercise to anticipate a more negative future than the formulated scenario suggests and then to do contingency planning on this basis. To a large extent the veracity of the scenario depends on the vision of those who develop the scenario, and developing scenarios in turn sharpens the vision of those involved.

The original meaning of the term scenario refers to a summary or sketch of the story-line or plot of a drama, providing details about the scenes, situations, etc. A scenario of a unit should encompass those future aspects which may influence the focus areas of the unit. 


\subsection{Assumptions regarding the future strategic position of a unit}

Planning is always directed to the future. Since the future is unknown, assumptions are necessary in addition to scenarios in order to obtain a feeling for the future. Assumptions are made regarding the position of the unit at a certain point in the future. This point may be set three or five years in the future and be referred to as the future strategic position. This refers to the position where the unit wants to be at a certain time in the future.

The assumptions made should be guided by the mission of the unit and assumptions also need to be made for all focus areas. Assumptions need to be supported by what has been achieved by the enterprise in the past, by its current situation and level of development, as well as by the vision of those involved. In short, all information generated by the strategic planning exercise up to the present time should be considered when making assumptions.

The better the strategic planning is done and the more experience those involved have in making assumptions, the more realistic the assumptions will appear once the original future strategic position is reached. It is self-evident that this position always moves forward in time, and therefore new assumptions need to be made constantly. If the assumptions are utilized correctly, it may be a valuable guide to management. Realistic scenarios and planning assumptions make proactive management possible and restrict reactive management, the latter usually being a sign of crisis management.

\subsection{Goals}

Given all the information available at this stage of the planning exercise, it becomes much easier to formulate goals than it would be without such information. Goals need to guide the unit towards the right accomplishment of the right tasks at the right time. Under such circumstances the unit will be an efficient and effective organization.

A unit needs short-term, medium-term and long-term goals to steadily guide it to its final goal. The long-term goals need to guide a unit during its entire existence. Medium-term goals for the next three or five years need to be derived from the long-term goals. During this process, assumptions about the future strategic position can play a vital supporting role. The short-term goals or strategic objectives for each year are derived from the medium-term goals.

In this way, a framework of objectives and goals can be developed, guiding the unit in a planned and organized manner.

Once the strategic goals for the next year have been formulated, they need to be prioritized. The prioritization of goals for the unit as a whole and for its subsections need to be done separately. Priority goals should then be opera- 
tionalized so that those involved may be clear as to the activities flowing from each goal. This serves as a valuable input for costing and for drawing up a target budget.

\subsection{Plan of action}

Planning is of no use unless it is implemented; therefore action plans need to be drawn up and staff need to be organized to carry out these plans. Should this not take place, planning is experienced as a useless and time-consuming activity, discrediting the entire planning exercise.

An action plan is incomplete unless it also contains the names of those to carry out the plans as well as the target dates at which the plans need to be carried out. Target dates should be set in such a way that the unit as a whole steadily reaches its goals.

\section{Management of a lexicographic unit}

Planning is a management function, and therefore it is not only management's task to ensure that planning is done, but also its responsibility to see to it that action plans are carried out and that planning is implemented. Control should be exercised to see to it that planning is correctly implemented and the outcome needs to be evaluated in order to establish whether the desired results are obtained. If so, the implementation of the planning may continue, or else the planning needs to be revised.

\subsection{Production management}

The primary goal of management at a lexicographic unit should be to create working and other conditions enabling those involved to produce high quality output. Such output should not only be delivered sporadically, but constantly.

From all the activities of the unit, it should be clear that management places a high premium on productivity. Production should be encouraged and performance should be rewarded. Productivity cannot be increased responsibly unless it can be measured. Production norms are necessary for the measurement of productivity.

There is often the view at lexicographic units that the production of lexicographers is not measurable. Where the measurement of productivity does indeed occur, the emphasis is virtually exclusively on input, e.g. how many citations are processed annually, whereas little attention is paid to output. For the manager, output is a valuable management mechanism. During the management process, output needs to be controlled and evaluated. It is of more value to the manager to know the monthly average number of manuscript 
pages delivered per lexicographer than to know how many citations were processed. As soon as the average output of the staff becomes predictable to a certain extent, the calculation of target dates and supporting resources needed becomes much easier.

\subsection{A management system}

Since a unit's performance needs to be managed, the manager should select or develop a management system by means of which performance can be managed. The performance of the unit as a whole is related to the completion of its action plans and the realization of its goals. The realization of goals needs to be managed as a whole so that the various sections of a unit do not move ahead of one another, but that the unit as a whole reaches its goals at the planned times.

Such a management system is known as an integrated performance management system and delivers good results when managing a lexicographic unit.

\section{Conclusion}

Planning does not guarantee the success of a lexicographic unit, particularly when such planning is not managed effectively. A lack of good planning and effective management is guaranteed to squander time and money.

\section{References}

Kroon, J. (Ed.). 1994. General Management. Pretoria: HAUM-Tertiary.

Landau, Sidney I. 1984. Dictionaries: The Art and Craft of Lexicography. New York: The Scribner Press.

Zgusta, L. 1971. Manual of Lexicography. The Hague: Mouton. 


\section{Lexicography in a Multilingual South Africa}

Abstract: On 12 April 1996 the State Language Services organized a language planning seminar, Lexicography as a Financial Asset in a Multilingual South Africa, held at the Bureau of the Woordeboek van die Afrikaanse Taal in Stellenbosch. A special feature of this workshop was the active participation not only of linguists and lexicographers involved in the academic and practical side of producing dictionaries, but also of those with commercial interests in this area, viz. publishers and marketers of dictionaries. An important part of the seminar was the contributions on the lexicographic needs of each of the eleven official languages of the Republic of South Africa.

This seminar was followed by a consultative meeting for stakeholders arranged by the Pan South African Language Board (PANSALB) on 31 October 1997 in Johannesburg. The purpose of the meeting was to explain to participants the state of the legislation concerning lexicography units, to inform participants of the language plan for the Republic of South Africa and the role of lexicography in it, to make participants aware of the preparation needed to establish a lexicography unit, and to obtain the view of participants regarding important lexicographic matters by means of a questionnaire and discussions.

This meeting was an important precursor to two further meetings which PANSALB arranged in the Johannesburg Civic Centre, namely the Lexicographic Meeting of the Existing Lexicographic Units of South Africa on 19 and 20 March 1998 and the Lexicographic Meeting of the Languages which do not already have a Lexicographic Unit on 14 and 15 May 1998. The delegates participated in establishing norms for the recognition of existing and new lexicography units, and for the provision of personnel to, and for the state subsidisation of lexicography units. Regulations for the lexicography units were also discussed.

The papers presented at these two meetings provide a synopsis of the state of lexicography in the different official languages of the Republic of South Africa. The assignment for the first occasion was to outline the mission, history and present situation of the existing units, namely of Afrikaans, English, isiNdebele, Sepedi, isiXhosa and isiZulu. The assignment for the second occasion was to delineate the state of lexicography in those languages which do not have lexicography units, namely Sesotho, Setswana, siSwati, Tshivenda and Tsonga.

Adapted and updated extracts from the documentation of these meetings are published here with the kind permission of PANSALB and of the presenters of the different papers.

These are preceded by an exposition of the procedure for the establishing of the lexicography units for the eleven official languages of the Republic of South Africa.

PANSALB was established in 1995 in terms of the Pan South African Language Board Act (No. 59 of 1995). To make provision for, inter alia, the creation of lexicography units by PANSALB, the Pan South African Language Board Amendment Act (No. 10 of 1999) was assented to this year. The aims of PANSALB are:

(a) to promote respect for and ensure the implementation of the following principles: 
(i) the creation of conditions for the development and for the promotion of the equal use and enjoyment of all the official South African languages;

(ii) the extension of those rights relating to language and the status of languages which before 27 April 1994 were restricted to certain regions;

(iii) the prevention of the use of any language for the purposes of exploitation, domination or division;

(iv) the promotion of -

(aa) multilingualism; and

(bb) the provision of translation and interpreting facilities;

(v) the fostering of respect for languages spoken in the Republic other than the official languages, and the encouragement of their use in appropriate circumstances; and

(vi) the non-diminution of rights relating to language and the status of languages existing before 27 April 1994;

(b) to further the development of the official South African languages;

(c) to promote respect for and the development of other languages used by communities in South Africa, and languages used for religious purposes;

(d) to promote knowledge of and respect for the provisions and principles of the Constitution relating directly or indirectly to language matters;

(e) to promote respect for multilingualism in general; and

(f) to promote the utilisation of South Africa's language resources.

Keywords: PANSALB, LEXICOGRAPHY UNITS, PAN SOUTH AFRICAN LANGUAGE BOARD ACT, 1995, PAN SOUTH AFRICAN LANGUAGE BOARD AMENDMENT ACT, 1998, AFRILEX, BUREAU OF THE WOORDEBOEK VAN DIE AFRIKAANSE TAAL, DICTIONARY UNIT FOR ISINDEBELE, DICTIONARY UNIT FOR SOUTH AFRICAN ENGLISH, NORTHERN SOTHO DICTIONARY UNIT, XHOSA DICTIONARY PROJECT, ZULU DICTIONARY PROJECT, SESOTHO LEXICOGRAPHY, SETSWANA LEXICOGRAPHY, SISWATI LEXICOGRAPHY, TSHIVENDA LEXICOGRAPHY, TSONGA LEXICOGRAPHY

Opsomming: Leksikografie in 'n meertalige Suid-Afrika. Op 12 April 1996 het die Staatstaaldiens ' $n$ taalbeplanningseminaar, Lexicography as a Financial Asset in a Multilingual South Africa, gereël wat by die Buro van die Woordeboek van die Afrikaanse Taal op Stellenbosch gehou is. ' $n$ Besondere kenmerk van dié seminaar was die deelname nie net van taalkundiges en leksikograwe betrokke by die akademiese en praktiese kant van die opstel van woordeboeke nie, maar ook diegene met kommersiële belange op hierdie gebied, nl. die uitgewers en bemarkers van woordeboeke. 'n Belangrike deel van dié seminaar was die bydraes oor die leksikografiese behoeftes van elkeen van die elf amptelike tale van die Republiek van Suid-Afrika.

Hierdie seminaar is gevolg deur 'n raadplegende vergadering gereël deur die Pan-Suid-Afrikaanse Taalraad (PANSAT) met belanghebbendes op 31 Oktober 1997 in Johannesburg. Die doel van die vergadering was om aan deelnemers die stand van die wetgewing betreffende leksikografie-eenhede te verduidelik, om deelnemers in te lig oor die taalplan van die Republiek van SuidAfrika en die rol van die leksikografie daarin, om deelnemers bewus te maak van die voorbereiding nodig om ' $n$ leksikografie-eenheid op te rig, en om die opvattings van deelnemers te 
verkry betreffende belangrike leksikografiese aangeleenthede met behulp van 'n vraelys en besprekings.

Hierdie byeenkoms was in belangrike voorloper van twee verdere byeenkomste wat deur PANSAT in die Burgersentrum in Johannesburg gereël is, $\mathrm{nl}$. Lexicographic Meeting of the Existing Lexicographic Units of South Africa op 19 en 20 Maart 1998 en Lexicographic Meeting of the Languages which do not already have a Lexicographic Unit op 14 en 15 Mei 1998. Die afgevaardigdes het deelgeneem aan die bepaling van norme vir die erkenning van bestaande en nuwe leksikografie-eenhede, en vir die voorsiening van personeel aan en staatsubsidiëring van leksikografie-eenhede. Bepalings vir die leksikografie-eenhede is ook bespreek.

Die referate wat by hierdie twee byeenkomste gehou is, gee ' $n$ oorsig van die stand van die leksikografie in die verskillende amptelike tale in die Republiek van Suid-Afrika. Die opdrag vir die eerste geleentheid was om die missie, geskiedenis en huidige omstandighede van die bestaande eenhede uiteen te sit, nl. Afrikaans, Engels, isiNdebele, Sepedi, isiXhosa en isiZulu. Die opdrag vir die tweede geleentheid was om die stand van die leksikografie te skets in die tale wat nog nie leksikografiese eenhede het nie, nl. Sesotho, Setwana, siSwati, Tshivenda en Tsonga.

Aangepaste en bygewerkte uittreksels uit die dokumentasie van die byeenkomste word hier gepubliseer met die vriendelike vergunning van PANSAT en die aanbieders van die onderskeie referate.

Hulle word voorafgegaan deur 'n uiteensetting van die prosedure vir die instelling van die leksikografie-eenhede vir die elf amptelike tale van die Republiek van Suid-Afrika.

PANSAT het in 1995 tot stand gekom kragtens die Wet op die Pan-Suid-Afrikaanse Taalraad (No. 59 van 1995). Om onder andere voorsiening te maak vir die stigting van leksikografie-eenhede deur PANSAT is die Wysigingswet op die Pan-Suid-Afrikaanse Taalraad (No. 10 van 1999) vanjaar aangeneem. Die oogmerke van PANSAT is:

(a) om respek te bevorder vir, en die implementering te verseker van die volgende beginsels:

(i) die skepping van toestande vir die ontwikkeling en vir die bevordering van die gelyke gebruik en benutting van al die amptelike Suid-Afrikaanse tale;

(ii) die uitbreiding van daardie regte met betrekking tot taal en die status van tale wat voor 27 April 1994 tot sekere streke beperk was;

(iii) die voorkoming van die gebruik van enige taal vir die doeleindes van uitbuiting, oorheersing of verdeling:

(iv) die bevordering van -

(aa) veeltaligheid; en

(bb) die voorsiening van vertalings-en tolkfasiliteite;

(v) die kweek van respek vir ander tale, benewens die amptelike tale, wat in die Republiek gepraat word, en die aanmoediging van die gebruik daarvan in gepaste omstandighede; en

(vi) die nievermindering van regte met betrekking tot taal en die status van tale wat voor 27 April 1994 bestaan het;

(b) om die uitbouing van die amptelike Suid-Afrikaanse tale na te streef;

(c) om respek vir en die ontwikkeling van ander tale wat deur gemeenskappe in Suid-Afrika gebruik word, asook tale wat vir godsdiensdoeleindes gebruik word, te bevorder; 
(d) om kennis van en respek vir die bepalings en beginsels van die Grondwet wat regstreeks of onregstreeks betrekking het op taalaangeleenthede, te bevorder;

(e) om respek vir veeltaligheid in die algemeen te bevorder; en

(f) om die benutting van Suid-Afrika se taalhulpbronne te bevorder.

Sleutelwoorde: PANSAT, LEKSIKOGRAFIE-EENHEDE, WET OP DIE PAN-SUID-AFRIKAANSE TAALRAAD, 1995, WYSIGINGSWET OP DIE PAN-SUID-AFRTKAANSE TAALRAAD, 1999, AFRILEX, BURO VAN DIE WOORDEBOEK VAN DIE AFRIKAANSE TAAL, DICTIONARY UNIT FOR SOUTH AFRICAN ENGLISH, SEPEDI WOORDEBOEKPROJEK, WOORDEBOEKEENHEID VIR ISINDEBELE, XHOSA WOORDEBOEKPROJEK, ZULU WOORDEBOEKPROJEK, SESOTHO LEKSIKOGRAFIE, SETSWANA LEKSTKOGRAFIE, SISWATI LEKSIKOGRAFIE, TSHIVENDA LEKSIKOGRAFIE, TSONGA LEKSIKOGRAFIE

\section{The National Lexicography Units - Existing and Prospective*}

M.B. Kumalo, Chairperson, Subcommittee: Lexicography and Terminology of the Pan South African Language Board, Pretoria, Republic of South Africa

\section{Introduction}

From a purely political point of view, there has been inequality and inequity in the funding of the development and promotion of a section of South African languages due to the laws that prevailed in the past. It is fitting, therefore, that the whole debate on the lexicography units is brought into its correct perspective, that is: lexicographical rather than political, at least now that there has been change in government policy. An opportune moment has now presented itself to redress the failures and shortcomings of the past.

Those in the Pan South African Language Board (PANSALB) who have been entrusted with this responsibility are determined to see to it that justice is done to everybody's satisfaction without diminishing existing benefits, and similarly, without short-changing previously deprived languages. Together and without anyone prescribing to the others, success is assured because this is a joint venture. PANSALB from its side shall facilitate movement and leave direction and pace to the native speakers and their academic technicians. PANSALB shall not impose itself on the units, but shall make it possible for them to take responsible decisions relevant to their specific and individual needs.

This is a slightly adapted and updated version of a keynote address given at the Third International Conference of the African Association for Lexicography, held at the University of Potchefstroom for CHE, Potchefstroom, 29-30 June 1998. 


\subsection{National Lexicography Units Bill}

The National Lexicography Units Bill which was on the verge of being passed as an Act of Parliament in 1997, was a controversial document. Some lexicographers were in fact guilty of already regarding it as a legal personality rather than as a document to be commented upon. However, it has contributed strongly to the debate and has alerted many to the possibilities and opportunities available. It highlighted the fact that there was one-sidedness and favouritism in funding and that equity was a necessity and a requirement to be striven towards. It also pointed out that all languages would be treated equally and given the same opportunity for advancement and that preferential treatment would no longer be given to any one language only. That disclosure was a positive indicator.

There were claims and counterclaims that the Bill had been sufficiently canvassed among those who were directly or indirectly affected as practising lexicographers in their various languages. As comments poured in, many of them very positive, however, the Minister found it expedient to withdraw it because of the impending establishment of the Commission for the Promotion and Protection of the Rights of Cultural, Religious and Linguistic Communities, whose powers would overlap with those of PANSALB which had been established under the Interim Constitution. Since PANSALB had a clear constitutionally mandated role in language development, the Minister found it important to withdraw the National Lexicography Units Bill with a view of possibly assigning the establishment of the National Lexicography Units to PANSALB. Great uncertainty followed until it became evident that its functions would be subsumed under PANSALB.

More to-ing and fro-ing ensued. The debate was reopened.

\subsection{Subsuming of the National Lexicography Units Bill into PANSALB}

The new constitution stipulates that the function of PANSALB is language development and the promotion of multilingualism. It was therefore argued that the subsuming of the National Lexicography Units Bill under PANSALB was in line and in keeping with this central function. To this end, several meetings took place between PANSALB and the Department of Arts, Culture, Science and Technology on the one hand, and between PANSALB and the Language Subcommittee of the Parliamentary Portfolio Committee on the other. A tripartite meeting between the Department, PANSALB and the Portfolio Language Subcommittee was held on Monday 4 May 1998 to expedite and finalise this matter. Documents were exchanged and further discussions took place, resulting in the draft Pan South African Language Board Amendment Bill, 1998. The Portfolio Committee submitted about six amendments and PANSALB about twenty. Although every member of PANSALB was in favour of the establishment and development of the different lexicography units, not 
every member was in agreement on or in favour of the manner of implementation. One member of PANSALB resigned as a result. The scepticism mainly concerned the question of funding. At that stage it was not very clear whether the units will receive funding directly from PANSALB or directly from Parliament. Section 10(1)(b) of the draft Regulations for the National Lexicography Units on the financing of a unit reads: "moneys appropriated by Parliament for the purpose of the unit". These regulations are still in draft form and have not as yet been approved by the Minister.

The Pan South African Language Board Amendment Bill, 1998, was assented to on 14 April 1999 as the Pan South African Language Board Amendment Act, Act No. 10 of 1999.

The preamble of the draft Pan South African Language Board Amendment Bill, 1998, reads as follows: "To amend the PAN SOUTH AFRICAN LANGUAGE BOARD ACT, 1995, to provide for National Lexicography Units, to bring the act in line with the provisions of the Constitution of the Republic of South Africa, 1996, and for matters connected therewith." The relevant parts in the preamble to the Pan South African Language Board Amendment Act, 1999, have been changed to: "To amend the Pan South African Language Board Act, $1995, . . . ;$ to establish lexicography units; ... to effect certain consequential and technical amendments necessitated by the supersedence of the Constitution of the Republic of South Africa, 1993, by the Constitution of the Republic of South Africa, 1996." As the units are meant to redress the shortcomings of the past, there was a need for a paradigm shift in light of the new Constitution.

To that effect, an addition was made to the powers and functions of PANSALB in Section $8(8)$ (c) of the draft Bill, which stipulates that the Board shall establish "national lexicographic units for each of the official languages of South Africa". The relevant section in the Act states that the Board shall establish "units to operate as companies limited by guarantee under section 21 of the Companies Act, 1973 (Act No. 61 of 1973), and shall allocate funds to the units for the fulfilment of their functions". Nowhere else does the draft Bill or the Act refer to these units.

However, it is important to note that the intention is to empower PANSALB to establish national lexicography units, and not to control or regulate them. In other words, PANSALB is to act as a facilitator only. It will not run the units. It is also obvious that PANSALB will have no authority whatsoever over the administration of the new units, let alone over already existing units, because each unit will have its own management committee of nine members. There seems to be a misunderstanding, deliberate or not, regarding the subsuming of the lexicographic functions of the National Lexicography Units Bill and the establishment of the units by PANSALB. The Bill was intended to establish the units, this function is now being subsumed under PANSALB.

According to Section 5 of the draft Regulations for the National Lexicography Units, each management committee shall, in addition to its other functions, 
(a) formulate and ratify the policy to be followed in order to achieve the objectives of its unit;

(b) govern and advise its unit in accordance with the resources at its disposal;

(c) decide from time to time about matters relating to the publishing, printing and marketing of the dictionaries and products of its unit; and

(d) determine from time to time the number of review, gift, working and other copies of products of its unit to be made available free of charge.

Each unit will have its own full-time staff under the supervision of an editor-inchief, who will be accountable to the management committee.

These draft regulations have been circulated and discussed at the three workshops organised by the PANSALB Lexicography and Terminology Subcommittee on 31 October 1997, 19 and 20 March 1998 and 13 and 14 May 1998.

The status of the various units, when all have finally been established, will be equal in so far as provisioning is concerned. There is no doubt, however, that even if that is the case, the Bureau of the Woordeboek van die Afrikaanse Taal, and to a great extent the Dictionary Unit for South African English, will remain above the others for a long time to come. The currently ongoing dictionary projects are funded by various institutions. The Department of Arts, Culture, Science and Technology finances the Woordeboek van die Afrikaanse Taal as well as the Dictionary for South African English. Some public funds are also made available to support other lexicography projects indirectly through university funding, viz., isiNdebele, isiXhosa, isiZulu and Sepedi. It remains to be seen as to how the available funds will be shared among all the units in future.

Another point that needs to be addressed, is the involvement of AFRILEX in the affairs of the lexicography units. A question has also been posed as to the significance of representatives from existing units attending workshops with units that are still under discussion. A simple answer to that is the cliché: There is no need to reinvent the wheel. One is inclined to support and agree with $\mathrm{Mr}$ Bernd Schulz's maxim enunciated by himself on 31 October 1997 that "from diversity comes strength: linguistic diversity, training diversity, management diversity". There should be moved away "from prescriptive either/ors to inclusive both/ands".

Already, representatives of the envisaged units have benefited tremendously from the seminars and workshops that have been offered since 1996, facilitated by both AFRILEX and by the experienced and well-funded units. Even if there is not anything linguistically called co-operative lexicography, cooperation is going to play a major role in all the units in future. The stage has now been reached where all languages will enjoy equality, although qualified, so it is important that all should work together in diversity and to become unified in diversity. 
All units are to be autonomous and cannot be dictated to from outside. All units will have the power to decide for themselves what it is they wish to achieve and how to achieve it. Isolation will impoverish perpetrators thereof. There is no need therefore to cherish fear of domination.

The important role to be played by AFRILEX, an association of professionals, cannot be overemphasised. So long as it exists, AFRILEX will be in a position to offer guidance, training, etc., while management committees, by the nature of their composition, cannot have the same expertise and capacity. All units will need each other as they have already shown unofficially. This mutual need is not, has not and can still not be imposed - but it is there. It is going to grow when the units begin to share the same major source of funding. The units of the previously marginalised and disadvantaged languages will require propping-up because of historical reasons. There are not enough sufficiently trained African lexicographers yet.

After a unit has been established, it will take leave of PANSALB and can no longer rely on PANSALB to assist it in any way whatsoever (unless in so far as funding is channelled through PANSALB), because it would then be autonomous and, hopefully, self-sufficient.

Whereas the majority of existing lexicography units are presently involved in the compilation of monolingual dictionaries, new units will, like the isiXhosa unit, have the advantage of exploring other options. The scope is very wide and deep.

\section{Conclusion}

PANSALB has specific responsibilities regarding the establishment of the lexicography units. These responsibilities can be summarised as follows:

(a) to finalise the norms in terms of which the approval of lexicography units will take place;

(b) to assist with the formulation of the regulations in terms of which the lexicography units will be managed;

(c) to submit the norms and regulations to legal representatives for preparation and publication in the Government Gazette and Provincial Gazettes;

(d) to invite the controlling bodies of existing lexicography units to seek approval in accordance with the norms and regulations;

(e) to consider ways in which languages which do not have lexicography units should seek approval;

(f) to inform approved units of the matter, and

(g) that once a unit has been approved, to pay immediate attention to the following matters:

(i) to decide on the seat of each unit in consultation with the stakeholders in the particular language (Section 1(2)); 
(ii) to determine the name of the unit in consultation with the relevant management committee (Section 3); and

(iii) to form a management committee and to appoint an editor-in-chief (Section 4(1)(a), (c), (d), (e), (f), (g), (h), and Section 9(1)).

It is necessary to co-operate and draw from available expertise and resources. It is necessary to understand that this will in no way undermine the independence and autonomy, nor the self-assertiveness of any unit. Instead, the opposite is likely to be true.

\title{
Bureau of the Woordeboek van die Afrikaanse Taal
}

\author{
B.P.D. Gabriels, A.E. Cloete and W.F. Botha, Coeditors, Bureau of the
}

Woordeboek van die Afrikaanse Taal, Stellenbosch, Republic of South Africa

\section{Aim and Task}

In 1989 the Bureau adopted a management system based on a process of intensive strategic planning, amongst other reasons to streamline its activities. When the planning committee formulated a mission statement for the Bureau, it based it on two cornerstones, namely its aim and its task, as well as all activities emanating from the aim (the ideals and aspirations of the founders of the Bureau), and all the activities which it was expected to perform and promote, as set out in the relevant legislature. Consequently, all the activities of the Bureau are driven and directed by its aim and task

The aim of the Bureau of the WAT is to serve the Afrikaans language and its users, as well as lexicography in general. The users of the Afrikaans language include all geographical, social, economic, cultural and professional groupings and standings of the Afrikaans-speaking community. Flowing from the aim, the task of the Bureau is:

- To continue with the compilation of the WAT, to complete it as soon as possible and to revise and improve the dictionary from time to time.

This, as the primary line function of the Bureau, will firstly be made possible by the continuous representative and comprehensive collection of the vocabulary of the Afrikaans language in all its variations, and the arrangement and storage thereof in a lexicographically workable form. In the second place, it will be made possible by editing the collected material according to scientifically established lexicographic principles in the form of an authoritative, user-friendly, synchronic, and explanatory dictionary in consecutive volumes in alphabetical order. 
- To grant controlled access to the language, material and resources of the Bureau to bona fide researchers and to answer linguistic enquiries.

- To establish, with the assistance of external authors, appropriate lexicographic products for the different languages of South Africa.

- To produce the WAT and its satellite publications cost-effectively.

This means that the printing and binding of the different volumes of the WAT and other publications should be done as quickly and as economically as possible, without sacrificing quality and appearance.

- To market these products dynamically and economically.

The Bureau will achieve this by stimulating the target market by innovative professional advertisements and publicity, aimed at maximum sales.

- To act as a growth point and stimulus for lexicographic activities and metalexicographic reflection.

- To liaise with South African and foreign lexicographic and other linguistic institutions with a view to exchanging lexicographic knowledge, information and publications.

- To contribute to lexicographic theory and practice in the form of scientific publications.

- To assist in raising the general level of lexicography, especially in Africa, through co-operation with other dictionary projects.

- To play an active role in removing inequalities in lexicography through training and the creation of jobs.

- To contribute to the establishment and development of South African lexicography in support of the aims of the Pan South African Language Board.

- To strive for need directedness, quality and the unity of character in its activities and products.

Against the backdrop of current developments in the field of lexicography, the mission of the Bureau will have to be reviewed. As more and more lexicography units are coming into being, the Bureau will in some respects readjust and redefine the angle of its partnership in order to be of prime service to South African lexicography as a whole.

The Bureau is unreservedly committed to playing a prominent role in the promotion and development of a culture of co-operative lexicography in all South African languages and within the broader African context.

\section{Establishment and Progress}

The history of the WAT started in 1920 when Prof. J.J. Smith advocated the compilation of a bilingual dictionary and the collection of the Afrikaans vocabulary, with a view to the compilation of a explanatory monolingual Afrikaans dictionary in the Afrikaans newspaper Die Burger. Five years later a joint 
committee of both houses of Parliament recommended the compilation of a complete and authoritative dictionary, with State support.

In 1926, co-operation between Prof. Smith, the Nasionale Pers and the University of Stellenbosch was ensured by formal contracts. Work on the dictionary was started in Cape Town. At that stage, the idea was that Prof. Smith would compile a dictionary similar to the Dutch Van Dale, in other words a standard descriptive dictionary, which was to be completed within three years. In those early years Afrikaans literature was limited and the linguistic description of Afrikaans still in a preliminary stage.

In 1929, the University of Stellenbosch took the responsibility for the dictionary from Nasionale Pers. Shortly thereafter the dictionary office moved to Stellenbosch, and in 1937 a dictionary committee was appointed as a controlling body.

In 1945, Prof. Smith retired due to ill health and the dictionary committee was replaced by a board of control consisting of representatives from the government, the University of Stellenbosch and the Suid-Afrikaanse Akademie vir Wetenskap en Kuns. When Prof. Smith retired after nineteen years of lexicographic labour, not a single volume had been published. However, manuscripts ranging from a preliminary to a revised state had been prepared, in the style of a standard dictionary, up to the letter $\mathrm{N}$.

There are reasons why nothing was published in nineteen years. By 1926, the Afrikaans language was not yet standardised. No extensive recording of the Afrikaans language had been undertaken and there was only a very limited corpus of literature which could be excerpted. No comprehensive study of the Afrikaans grammar had been undertaken, many spelling issues still had to be resolved, and furthermore there was an almost complete lack of technical terms.

Two other impeding factors were the absence of etymological research and contradicting opinions on the inclusion of Dutch words. Some critics were convinced that the database of Prof. Smith was too Dutch-oriented, whilst others propagated the inclusion of more Dutch words.

In October 1946, Dr P.C. Schoonees was appointed as second editor-inchief. When the first volume of the WAT was published four years later in 1950, it was not a dictionary in the tradition of a Van Dale or a Shorter Oxford as it had always been expected. It had the character of a comprehensive descriptive dictionary and was on the whole well received by academics, writers and users.

It can therefore be argued that 1950 marked the real beginning of the WAT. In 1951, the editorial staff was enlarged to ten members.

To compensate for the lack of Afrikaans technical terms, many Dutch terms were included in the first volume of the WAT. Following the advice of leading linguists, other Dutch words were also included on the grounds that they could be necessary for Afrikaans in the future, even though they were not 
part of the Afrikaans vocabulary at the time of compilation. None of these words really became part of the Afrikaans lexicon, as Afrikaans and Dutch continued to move further apart from each other. No etymologies were given, but the language of origin was provided in the case of loan-words. Thus, by the time the first volume of the overall descriptive WAT appeared in 1950, no standard descriptive dictionary had been published. By 1950, Afrikaans had a well-established written literature and compilers of dictionaries could benefit from a greatly but not completely standardised language. Volumes II, III and IV were respectively published in 1955, 1958 and 1961, and were all enthusiastically received.

In 1962, Dr F.J. Snijman was appointed as the third editor-in-chief and in 1963, the first millionth language data record was received by the WAT. Unfortunately, the publication of volume V in 1968, of volume VI in 1976 and of volume VII in 1984 was marked by strong criticism aimed mainly at the slow alphabetic progress, the encyclopaedic treatment of lemmas and the strong accent on technical terms.

In 1970, the second millionth record was received and in 1973, the Woordeboek van die Afrikaanse Taal Act, Act No. 50 was passed. The dictionary was established at Stellenbosch on a permanent basis, although not as part of the University of Stellenbosch. Henceforth the Bureau of the WAT was under a board of control consisting of five members in which the State, the University of Stellenbosch and the Suid-Afrikaanse Akademie vir Wetenskap and Kuns were represented.

In 1981, Mr D.C. Hauptfleisch was appointed as fourth editor-in-chief and in 1983 the collection of lexical material reached the three million mark, owing to the enthusiastic collaboration of language users across the country. This collection of lexical material is an ongoing process.

The Woordeboek van die Afrikaanse Taal Amendment Act, Act No. 9 was passed in 1986. The board of control was enlarged to six members. The administrator, in future also the permanent chairman, and the editor-in-chief, are $e x$ officio members and four members are appointed by the Minister of National Education. One member represents the Suid-Afrikaanse Akademie vir Wetenskap en Kuns.

The fact that the compilation of the three and a half volumes of the letter $\mathrm{K}$ took almost thirty years gave rise to predictions that it would take more than two hundred years to complete the WAT, which would then to a large extent not be a true reflection of the Afrikaans language any more. Therefore, in 1987 the Bureau started with its computerisation program in order to accelerate the editorial process and in 1989 a process of strategic planning was implemented with a view to completing the dictionary up to the letter $Z$ as quickly and effectively as possible.

The achievements of the WAT are all the more remarkable when one bears in mind that almost every possible mistake, especially as far as management 
and planning are concerned, was made. Hopefully future lexicographers would learn from the WAT's experience and would not be prone to the same mistakes.

\section{The current situation}

By 1989 it was clear that in spite of some measures implemented to accelerate the work on the WAT, the editors were not reaching their goals fast enough.

What really changed the situation was the strategic planning undertaken in 1989. It was done under the guidance of Dr D.J. van Schalkwyk, who was then senior coeditor and who became editor-in-chief in 1991. At the same time, the computerisation of activities was increased to its fullest extent and with the help of metalexicographers an optimally user-friendly dictionary was being pursued.

The entire editorial staff was involved in the strategic planning and by the completion of the process after six months, in November 1989, a mission was defined, aims and goals were formulated, action plans were worked out and target dates were set. Ten focus areas of the Bureau were identified, namely:

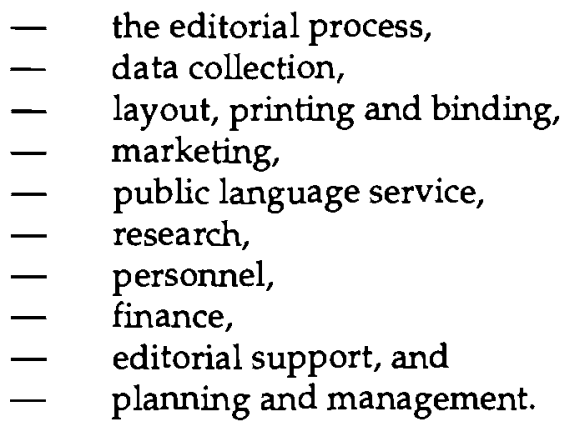

Thereafter the replanning of the design of the dictionary was started, which was done in close co-operation with nine leading South African linguists. They were all involved in lexicographic projects and most of them also lectured in lexicography. A new editorial manual or style guide was developed, incorporating as many of the suggestions of the metalexicographers as was practically possible.

The principal aim of the strategic planning was to speed up the work on the dictionary drastically and this was realised when volumes IX and $X$ were each completed within a period of two and half years. The completion of the two preceding volumes each took an average of seven years. This increased output was made possible by several positive outcomes of the strategic planning, such as good management, the development of production norms, a strict adherence to target dates, computerisation, and the development of a new manual or style guide. 
The database also benefited from computerisation as the electronic corpus is now far bigger than the card collection. The staff also have access to e-mail and the Internet and the Bureau of the WAT has a website.

Inspired by one of the aims in the mission, i.e. to act as a growth point and stimulus for lexicographic activities and metalexicographic reflection and to liaise with South African and foreign lexicographic institutions, it was decided to publish a series of journals and books under the banner of AFRILEX.

In 1991, Lexikos, a lexicographic journal, became the first publication in the AFRILEX series. As the only professional journal in Africa devoted exclusively to lexicography, it has since then appeared annually.

One of the principal aims of the AFRILEX series was to promote the establishment of a lexicographic society for Africa. This stemmed from the Bureau's awareness of the expertise present in other lexicographic projects in South Africa, which led to its investigation of the idea of co-operative lexicography. In July 1995, the African Association for Lexicography, AFRILEX was established and in 1996, Lexikos became its official mouthpiece. Lexikos is however still compiled and published by the Bureau.

One of the most important reasons for the acceleration of the work on the dictionary was the development of production norms for all staff members. Once production norms had been introduced, the Bureau developed an inservice training course which aimed at developing the lexicographic skills of new staff members as rapidly as possible.

As the idea of co-operative lexicography gained momentum at the Bureau, a training course for lexicographers and people interested in lexicography from outside the Bureau was developed in 1995. This course in general and computer lexicography and in the planning and management of lexicographic projects stretches over two weeks and is usually offered twice a year. Since 1995, students, lecturers, practising lexicographers and persons intending to become involved in dictionary compilation have attended the course. Participants have come from almost all the provinces of the Republic of South Africa and from as far as Angola, Namibia, Gabon, Tanzania and Zambia.

In 1997, two of the staff members of the Bureau also offered the course at the Centre International des Civilisations Bantu (CICIBA) in Libreville, Gabon, where six African countries were represented.

The Bureau wholeheartedly supports the initiatives of other dictionary projects, such as the Dictionary Unit for South African English and the Sepedi Dictionary Project, to offer training programmes.

At the end of every year, the Bureau formulates strategic aims for the next year in order to ensure that the staff works purposefully. The editor-in-chief draws up a goal-orientated budget in accordance with these strategic aims, which assists goal-orientated management. To contribute to lexicographic theory and practice, staff members annually produce scientific publications and deliver papers at national and international congresses.

True to its mission, the Bureau started producing satellite dictionary publications in co-operation with external authors in 1992. Such publications 
appeared in 1992, 1994 and 1995, and included a dictionary of idioms and a mini thesaurus. An etymological dictionary is currently being compiled in cooperation with both international and national external authors. The typesetting of these publications as well as that of the WAT itself is done by the Bureau.

The Bureau has undergone a transformation over the past ten years, resulting in an organisation managed according to modern principles, in the acceleration of work on the dictionary and in a redesigned dictionary which reflects state of the art linguistics as far as is practically possible. A desire to cooperate with other projects, to learn from their experience and expertise and to share its own expertise, especially in the fields of joint publications, training, computerisation and the planning and management of a lexicographic project has also developed.

\title{
Dictionary Unit for isiNdebele
}

\author{
P.B. Skhosana, Department of African Languages, University of Pretoria, \\ Pretoria, Republic of South Africa
}

\section{Introduction}

At the conference Lexicography as a Financial Asset in a Multilingual South Africa held in 1996 at the Bureau of the Woordeboek van die Afrikaanse Taal in Stellenbosch, it was indicated that isiNdebele lexicography was still nonexistent. At that time, most of the necessary basic work had not yet been done, for instance:

- printed and published literary material in isiNdebele for corpus building was insufficient,

- consultation with all the relevant stakeholders of isiNdebele had not yet taken place, and

isiNdebele itself was not yet a university subject like the other official languages of South Africa.

However, the conference acted as an eye-opener. The establishment of a dictionary unit for isiNdebele was mentioned as an urgent need, since not a single isiNdebele dictionary existed. This need still exists, even though some remarkable progress had been made towards establishing an official Dictionary Unit for isiNdebele.

\section{Mission statement}

It is the aim and the objective of the Dictionary Unit for isiNdebele to produce a comprehensive monolingual dictionary that will benefit the mother-tongue 
speakers of isiNdebele and also all other South Africans who are interested in studying the language within a short period. The product should benefit scholars, students and professionals. As dictionary making is not an easy short-term process, the Dictionary Unit for isiNdebele does not intend to complete the letters of the alphabet consecutively, but to work on a complete dictionary, increasing the scope and volume as the project continues. This seems to be the best strategy to short-circuit the lengthy period dictionary users will have to wait before the first isiNdebele dictionary becomes available. A bilingual dictionary that will be of benefit to the non-mother-tongue speakers of isiNdebele is also considered.

\section{History and mandate}

The establishment of officially funded dictionary units for all the African languages of South Africa demands proper planning and a joint venture in order to make these units successful. That is the reason why the Dictionary Unit for isiNdebele went through a number of important stages in the past two years in order to qualify for recognition and official funding. An open and successful consultative conference was held in Mpumalanga at Loopspruit Wine Cellars on 14 March 1997. The main aim of this conference was to ascertain whether there is any support from grass roots level for the establishment of the dictionary unit for isiNdebele and to assure that the unit functions in close co-operation with all the stakeholders involved in the development of isiNdebele. More than 50 delegates representing major role players, individuals, interested parties and institutions such as the South African Bible Society, AFRILEX, National and Provincial Departments of Arts, Culture, Science and Technology, universities, writers' associations, specific language bodies, tribal institutions etc. attended the conference. Overwhelming support for the following issues was received:

- that as a starting point a monolingual type of a dictionary be the first priority,

- that the initiative of the Department of Arts, Culture, Science and Technology of Mpumalanga to find a possible and suitable institution or venue that can host this unit, is highly appreciated,

- that the University of Pretoria, the nearest tertiary institution to the speakers of isiNdebele and the only university willing to introduce this language as a university course in 1997, be officially approached to host this unit,

that official correspondence also be extended to PANSALB for recognition and support, and

- that in order to ensure that the unit starts functioning successfully and progresses well, Mr P.B. Skhosana be nominated as the person responsible. 


\section{Corpus collection and building}

While waiting for the government to come up with official directives and guidelines on the composition and size of the management, personnel and other official administrative procedures for funding, the Unit started with the corpus collection. It managed to compile a reasonably extensive data corpus from written sources of isiNdebele literary works as well as oral material recorded from native speakers of isiNdebele. In addition to this, it has already started with the electronic scanning of isiNdebele literary works for the purpose of compiling a head-word list as well as for word-frequency studies. Through the support of the stakeholders and academic staff of the University of Pretoria, among others Prof. D.J. Prinsloo and Prof. A. Wilkes, about 20000 entries have been collected so far.

The intensive two-weeks-long workshop, the SALEX '97 Lexicographical Training Course, which was held in Grahamstown from 15-27 September 1997 was attended by the Dictionary Unit for isiNdebele as part of its ongoing training programme.

\section{Conclusion}

The Dictionary Unit for isiNdebele is still in its infancy. Training and close contact with those experienced in the dictionary-making processes are prioritized. The Dictionary Unit of isiNdebele will therefore not adopt a policy of working in isolation but will profit from the excellent expertise available from already well-established projects.

\section{Dictionary Unit for South African English}

Penny Silva, Former Executive Director, Dictionary Unit for South African English, Rhodes University, Grahamstown, Republic of South Africa

\section{The main objects and the mission statement of the Dictionary Unit}

The original mission statement reads as follows:

The continuous and comprehensive collecting, arranging and storing in a lexicographically workable form of the vocabulary of the English language as used in Southern Africa and the editing and publication of the collected materials in the form of a Dictionary of South African English on Historical Principles, as well as periodical revision and updating of the text thereof and other research and publications associated therewith. (Memorandum of Association, 1991) 
When the monolingual dictionary had been published, it was realised that the object had to be extended and the Registrar of Companies had therefore to be approached to accept a change in the mission statement.

With the addition of 1 (b) and (c) and 2, the total mission statement now reads as follows:

1. The continuous and comprehensive collecting, arranging, and storing in a lexicographically workable form of the vocabulary of the English language as used in Southern Africa and the editing, adaptation, and publication of the collected data in printed and electronic form -

(a) as a Dictionary of South African English on Historical Principles,

(b) as similar dictionaries, and

(c) as a component of English or bilingual dictionaries (in collaboration with other agencies),

as well as periodical revision and updating of these texts, and other research and publications associated therewith.

2. The preparation and provision of short courses in lexicographical theory and methodology.

All these aims are realised simultaneously. But the main aim is the documentation of English in South Africa, how it is used, how it is affected by other languages, the differences in English in South Africa from English everywhere else. English changes rapidly, being a language which not only develops new meanings within its own vocabulary stock, but also borrows from other languages with which it comes into contact.

To add to the main object of the Dictionary Unit, there is a general statement of ideals which is the following:

The Dictionary Unit for South African English affirms the value and dignity of all South Africa's languages and the need for their development and documentation. The Unit recognises and values the contribution made by all the country's languages to the development of South African English and is committed to reflecting the rich heritage of our multilingual society. It believes that developing a pride in South Africa's languages is a powerful component of nation building.

Considering the central role of English as a language of communication between South Africans and with the wider world, the Unit is committed to the recording of the history and culture of English in South Africa and the study of its changing vocabulary. The Unit is also committed to producing dictionaries which will enable better access to English by all of the country's communities, and also to sharing expertise through teaching, training and consultation.

In order to contribute to the world-wide study of English and to ensure that South African English maintains and develops its place as a 
member of the family of world Englishes, the Unit undertakes to share its knowledge of South African English with the international community of lexicographers.

\section{The early history of the Unit}

\subsection{Establishment and consolidation}

The first dictionary of South African English, Africanderisms, was published in 1913, compiled by an amateur lexicographer - a Methodist minister, the Revd Charles Pettman. Emulating the Oxford English Dictionary, Pettman's dictionary illustrated usage by including quotations from printed works.

The next South African dictionary appeared only in 1975 - A Dictionary of English Usage in South Africa, compiled by Ridley Beeton and Helen Dorner, of the University of South Africa, Pretoria.

In mid-1968, William Branford, then professor of English Language at Rhodes University, Grahamstown, seeing the need for ongoing research on South African English, initiated a pilot project, employing Peter Kota as parttime editorial assistant during 1969. The Dictionary Unit for South African English was established as a project of the Institute for the Study of English in Africa, at Rhodes University. The Unit aimed to investigate the extent to which South African English was distinctive from other Englishes, and whether documenting it would be feasible.

In 1970 Betty McLeod was appointed as the first full-time professional researcher, and subsequently Penny Silva joined the Unit in August of that year. Under Professor Branford's supervision she was assisted by Doreen Gray in collecting quotations from books, manuscripts, magazines, and newspapers and mounting them on index cards in order to illustrate English usage in South Africa. Rare early printed and manuscript material was read in the University library, and contemporary material was gleaned from a competition run in a national magazine, as well as from wide reading of modern publications. Mrs Silva began drafting entries in 1971. Jean Branford joined the staff during that year, followed by Margaret Britz, and, in 1974, by John Walker. Work was overseen by an editorial committee chaired by Professor Branford and drawn from the academic community. By the end of 1973, a working system had evolved, a style had been designed, and the first thousand entries had been written for the planned Dictionary of South African English on Historical Principles.

\subsection{Financial support}

In May 1969 Professor Branford wrote to the Human Sciences Research Council (HSRC), asking for support for a permanent unit. In December of that year the 
Council granted the sum of R19 000, which enabled the project to continue its work until 1973. The HSRC referred the matter to the Department of National Education, with a strong recommendation that a permanent institution be established "along the lines of the office of the Afrikaanse Woordeboek, at the University of Stellenbosch".

However, a sixteen-year-long struggle for the establishment of a permanent unit followed. Throughout this period the Department of National Education supported the Unit with ad hoc annual grants, which made effective planning and the appointment of staff on a long-term basis almost impossible.

For the period April 1975 until March 1981, the Unit received a single grant of R90 000 from the Department of National Education. As this amount did not cover costs, each year the considerable shortfall was met by a grant from the University Council. A further subvention was given for the period 1981 to 1984. In 1985 the Department of National Education finally agreed to make the project permanent, and a more realistic annual grant was allocated.

Since 1994, the Unit has been supported by the Department of Arts, Culture, Science and Technology. Tribute should be paid to Professor Branford's foresight in initiating research into the South African English vocabulary, and to his perseverance in obtaining money, year by year, to support this work. The Unit has filled a gap in international lexicography for English, and has documented both the creativity of local English and the effects on it of the other South African languages. The Unit has also established South African English lexicography as a scholarly discipline, nationally and internationally.

\section{$2.3 \quad$ Staff}

The staff of the Dictionary Unit has usually been small: for instance, in 1970 there was one full-time researcher with a part-time typist; in 1976, one parttime researcher, an editorial assistant, and a part-time typist; and in 1988 one senior and three junior full-time researchers, one part-time researcher, and a part-time typist.

Because there had been some savings made over the years, in 1990 the staff complement was expanded in order to prepare for the editing of the large Dictionary of South African English on Historical Principles over the following five years. From 1991 to 1995 there were five editors, one part-time editor and a keyboarder, with temporary assistance from students. In 1996 and 1997 there were five editors, one part-time editor and a part-time keyboarder. During 1998 the staff consisted of three editors, two part-time editors and a part-time keyboarder.

While over the years many worked in the Unit for very short periods of time, two editors ensured continuity, making a major contribution: Jean Branford from 1971 to 1989, and Margaret Britz from 1971 to 1991. 


\section{$2.4 \quad$ Legal status}

The Unit's precarious position changed in June 1991 when it was established as a permanent national body. After lengthy negotiations between the Department of National Education and the University, the Dictionary Unit for South African English was established as a Section 21 non-profit company with a nationally representative board of directors. It is associated with Rhodes University as a research institute and has been an associated institution of the Department of Arts, Culture, Science and Technology since 1994.

\subsection{Publications associated with the Unit}

The first small sample of work in progress - fifty entries - was published in 1971 as a report to the Department of National Education. In 1976, interim unpublished text of between one and two thousand entries was produced, again for the sponsors of the project. It was titled Voorloper ("one who walks ahead"). Agterryer ("one who rides behind") followed in 1984, as a further report to the Department.

In 1978, Jean Branford's Dictionary of South African English was published by Oxford University Press as a short dictionary for general readers, and four editions have appeared, the most recent in 1991. William Branford edited the South African Pocket Oxford Dictionary, published in 1987 with a second edition in 1994.

During the preparation of the Dictionary of South African English on Historical Principles, email was invaluable, as it provided almost immediate access to expert consultants in many fields, and particularly to the historical lexicographers of the Oxford English Dictionary in Oxford. The South African editors were not only able to ask questions and exchange data, but also to undergo an informal, long-distance training in historical lexicography, owing to the generosity of their Oxford colleagues. This reshaped the style and scholarship of the dictionary considerably as the editing progressed over the five-year period.

The dictionary was published in August 1996. The delivery of the text to the publishers appears to have been a world first: the huge and complex electronic text was transmitted to Oxford entirely on the Internet, with a stop in the United States in order to have tagging added. The dictionary is online in the Dictionary Department in Oxford, enabling lexicographers to have access to information on South African English as they add new words to world dictionaries including the Oxford English Dictionary, the New Oxford Dictionary of English, and the Concise Oxford Dictionary.

After the dictionary had been completed the Unit began to look in new directions, and in 1995 work was begun on the Francolin Illustrated School Dictionary for Southern Africa, a learner's dictionary for the higher primary school, compiled mainly for rural and township children. The editors were Dorothea Mantzel and Bernd Schulz, and the text was compiled with assistance 
from two non-governmental organisations working in literacy, the Molteno Project and the Read Educational Trust. The book covers a vocabulary of 3414 words (including core South African words and 800 curriculum terms), uses simple language, and provides illustrative sentences and many line drawings. It was tested in forty-six rural schools in six provinces before publication in July 1997.

\subsection{Training and teaching}

In 1997 the Unit became involved in the practical training of lexicographers. The British Council assisted by bringing three experienced British lexicographers and trainers to run the course, under the leadership of Sue Atkins. SALEX ' 97 was organized by the Unit under the auspices of AFRILEX and the Department of Arts, Culture, Science and Technology, and took place in Grahamstown in September 1997. It was the first course of three planned by AFRILEX with the central goal of enabling the staffs of new units for the nine African languages.

The ten-day course was attended by thirty-five participants representing fifteen languages - ten of the eleven South African official languages, and several languages from beyond South African borders. Each working day consisted of two lectures and two related workshop sessions, and every participant went away with a large file containing the course material for later use. Response to the course was positive, and a heartening spirit of common purpose developed among those present.

The Unit has established contact with schools, in Grahamstown and in the Eastern Cape. A pilot website has been set up at a local primary school, enabling the children to send words to the Unit - particularly school slang which they think might be useful in the documentation of South African English. One of the editors has visited the school, talking to both pupils and teachers. It is hoped to extend the project to other schools. Contact was made with the provincial Department of Education, offering the Unit's resources.

The Unit has also participated in Grahamstown Foundation projects, lecturing teachers on dictionary use, speaking at the National Festival of the Arts, and at national and provincial schools' festivals, and preparing material for the English Olympiad (an essay competition for high school pupils).

\section{$2.7 \quad$ Resources}

Money has always been tight, and in the future the situation is unlikely to improve. About $86 \%$ of the funding is spent on staff salaries. The Unit does not have the funds needed to send staff to conferences, to provide training, even to buy reference books for its small library.

The Unit benefits greatly from the University's resources, including services such as the management of its finances, administration of the payroll, and 
membership of the University's pension, medical aid, and group life schemes. The University also provides access to email and to computing expertise, as well as assistance with marketing and personnel matters. The Unit rents accommodation from the University at a subsidized rate, and benefits from using the University's messenger services, cleaners, and maintenance staff. The University library and the specialisms of the academic staff are invaluable resources. The Unit pays the University $5 \%$ of its annual income for these services.

\section{The Unit's place in changing society}

Since the large dictionary was completed, tasks have become much more diverse and the staff háve had to learn a range of new skills. Two major factors affect the way in which the Unit sees its future. The national position of English began to change in 1990 when it became the language of negotiation between the National Party government and the African National Congress (ANC). Despite being just one of the eleven official languages, English has become a language of communication at central government level and in many regions. There is a growing need for a range of access to English dictionaries, suited to the diverse community.

The Unit is about to turn its attention to South Africanising British dictionaries, for both first- and second-language speakers of English, adding South African vocabulary and special senses. There will also be a growing need to work with the units for all the other South African languages, especially perhaps in the preparation of bilingual dictionaries, where the Unit could manage a "framework" for English, and provide this as a resource for the creation of the other side of the bilingual dictionary.

Then there is the increasingly sophisticated technology available to the lexicographer. With diminishing resources for staff, and increasing demands being made, it is vital to hamess this technology. The Internet, email, scanning, electronic corpus-searching, CD-ROM, SGML-tagged text, networked workstations - all of these resources are already in use in the Unit, but need to be refined and extended. All computers have recently been upgraded to the same capacity, so that these resouces can be accessed by all staff.

One of the Unit's editors, Madeleine Wright, is designing lexicographical editing software, configuring SGML to suit the Unit's needs within a commercial word-processing package, and investigating commercial search engines. The huge task of capturing the Unit's thousands of index cards electronically is still to be accomplished.

At the same time the Unit continues to update the large dictionary and to collect data for it: but the window period between contracts is also used to evaluate and reorganise the various systems in place in the Unit, so that it is ready to meet the new demands of the years ahead, under the leadership of its new director, Katharine Kavanagh. 


\section{Sepedi Dictionary Project}

D.J. Prinsloo, Department of African Languages, University of Pretoria, Pretoria, and K.J. Mashamaite, Department of Northern Sotho, University of the North, Sovenga, Republic of South Africa

\section{Mission}

The mission of the Sepedi Dictionary Unit is to compile a monolingual explanatory dictionary. Since the need for dictionaries is so great, it will suit the interests of all prospective users to publish spin-offs from the project on a regular basis while completing the final project.

\section{History}

In 1988, the Department of African Languages at the University of Pretoria was formally appointed or instructed to establish a dictionary project for Sepedi with the final goal to compile a comprehensive multi-volume monolingual dictionary for Sepedi, with the now discontinued Sepedi Language Board as the controlling body. This was to be a major dictionary project similar to the Woordeboek van die Afrikaanse Taal. A well-motivated request for funding of approximately $\mathrm{R} 1$ million per year was well received by the authorities but no money was granted.

When the University of Pretoria was subsequently approached, it allocated an amount of more or less R8 000 per year. In addition, the University also provided the comprehensive infrastructure in the form of an office, telephone, fax and up-to-date computer technology and free services of computer programmers. The annual cash allocation of R8 000 is too small to hire a single full-time lexicographer, but it is utilised in the most effective way to maintain the project.

A Dictionary Committee was formed and supplemented from time to time, namely P.S. Groenewald, J. Maripane, K.J. Mashamaite, M.J. Mojalefa, D.J. Prinsloo and B.P. Sathekge. These members work on the dictionary in their spare time. Not a single member could be released from his duties as lecturer to attend to the dictionary on a full-time basis. This situation has slowed down the process considerably and is still far from what was initially hoped to be achieved in terms of full-time dictionary compilers. Nevertheless, much progress has been made since 1988. A word-frequency study based on a 1,5 million word corpus has been completed.

As for the dictionary itself, almost 50000 entries have been computerised. Two pocket-size bilingual dictionaries based on the research done and experience gained are already on the market. A comprehensive single volume English-Sepedi, Sepedi-English dictionary is scheduled to be on the market within 
the next three years. However, these remain spare-time efforts. At the moment the team is assisted by Mr G.-M. de Schryver from the University of Ghent in Belgium.

In 1996, co-operation with the University of the North was established, the University being represented by Mr K.J. Mashamaite.

In 1997, a formal business plan for the establishment of a dictionary unit was presented to the Department of Arts, Culture, Science and Technology.

The Sepedi Project held a consultative meeting on 13 August 1999 at the University of the North. The aim of this meeting was to bring all role-players together to:

- discuss the dictionary needs of Sepedi,

- communicate the latest legislation regarding dictionary units,

- obtain expert advice on the compilation of monolingual dictionaries,

- extend the mandate of the Sepedi Project Committee to compile a monolingual dictionary,

- appoint more members to the Sepedi Project Committee, and

- mandate the new committee to draw up a business plan according to the requirements of PANSALB.

The Dean of the Faculty of Arts, Mr S. Mashegoane, officially opened the meeting. The coordinators of the Sepedi Project, Prof. D.J. Prinsloo and Mr K.J. Mashamaite respectively read papers on the "Sepedi Dictionary Project: Past to Present" and the "Sepedi Dictionary Project: Present to Future". Ms Eleanor van Zuydam, Deputy Director: Language Development (National Lexicography Units), addressed the meeting on "Norms and Regulations for the Establishment of a National Lexicography Unit for Sepedi". This was followed by a presentation entitled "Compilation of a Monolingual Dictionary for Sepedi" by Prof. R.H. Gouws. Finally an in-depth discussion by role-players was held and it was decided to increase the Project Committee with five more members. The meeting accepted the offer by the University of Pretoria that the University of the North will become the new head office of the Sepedi Project, with the University of Pretoria acting as its branch office. A set of monolingual English dictionaries was donated to the Sepedi Project by the Dictionary Unit for South African English.

Much lexicographical research has evolved around the Dictionary Project. For example, a course work M.A. was introduced at the University of Pretoria five years ago and approximately fifteen students enrol annually for either magister or doctoral studies in African Language Lexicography. In-depth research into the problematic aspects of lemmatisation in Sepedi, as well as word-frequency studies have been done. The Project developed sophisticated word-frequency and concordance computer programmes and in co-operation with AFRILEX, has taken the initiative to compile a computer program for the compilation of dictionaries which might be useful to other projects as well. 
The Sepedi Dictionary Project is doing fine under the circumstances. A lot of work and research has already been done. A lot of lexicographical problems have been solved. The University of Pretoria is prepared to continue with its support on all levels. The Sepedi Project already has a lot to offer to other dictionary projects for African languages in terms of research done, training offered, computer programs developed, etc.

\section{The future}

The history of lexicography and lexicographic research in African languages is marked and dominated by research output from non-mother-tongue speakers of the languages. Common examples can be found in the numerous dictionaries in each African language today. All compilers are non-mother-tongue speakers and in some cases mother-tongue speakers are co-compilers. These mother-tongue co-compilers did not have any knowledge of the principles of lexicography and of metalexicography in particular.

Non-mother-tongue speakers fulfilled an important function in the development of the African languages. But it is important that the mother-tongue speakers now double their efforts and commitment to make it their task and obligation to write and compile dictionaries in their respective languages.

Institutions of higher learning such as universities and technikons, especially at the historically black universities, should take the initiative to accommodate lexicography units and start offering courses in lexicography, because this is an urgent need.

The University of the North has demonstrated this in two ways. Firstly, in 1994, two staff members were sent to the Free University of Amsterdam in the Netherlands to follow a professional Masters programme in lexicography. Secondly, lexicography as a course has been introduced at undergraduate and postgraduate level at the University of the North.

At the University of the North co-operative lexicography is encouraged. The University and the University of Pretoria have reached an important partnership in Sepedi dictionary projects. The needs of the community are far more important than those of the individual institutions. Although the ultimate goal is to complete a comprehensive monolingual dictionary of Sepedi, the compilation of a standard monolingual dictionary of Sepedi and other bilingual learner's dictionaries should also be considered.

For these projects to yield comprehensive and representative products that are reliable and that would meet the needs of the users, an extensive Sepedi vocabulary gleaned from various fields such as commerce and industry, government, religion, law, etc., has to be built into the Sepedi database. This exercise will need adequate funds to employ and train research assistants to gather oral information as well as data from the printed media. 


\section{Xhosa Dictionary Project}

T.X. Mfaxa, Editor, Xhosa Dictionary Project, University of Fort Hare, Alice, Republic of South Africa

\section{The mission and aims of the project}

The Xhosa Dictionary Project's mission is to serve the interests of the isiXhosaspeaking community in accordance with the basic human rights of this community, and fulfilling its members' needs by recording, using, developing and advancing the use of the language in oral, written and electronic form and in its multilingual interaction with all other language groups, both locally and abroad.

The aims are summarised as follows:

The primary aims are -

- to compile a national corpus of the isiXhosa language and to produce a comprehensive explanatory dictionary of isiXhosa;

- to provide a research facility for the study of the language in general and lexicology and lexicography in particular;

- to provide isiXhosa language services and support services, including translation services, terminology services, abridged dictionaries and specialised dictionaries, and reference services for researchers and language users;

- to promote and improve co-operative lexicography by means of experience gained over the years; and

- to complete the remaining volumes of the Greater Dictionary of Xhosa.

Secondary aims are -

- to establish a national lexicographic centre for African languages to advance the concept of multilingualism and promote the use of previously marginalised languages like isiXhosa;

- to monitor, report and advise on the viability of isiXhosa as a medium of communication at all levels in society, both within its mother-tongue community and beyond; and

- to play a significant role in the marketing and ultimately sales of both the larger and the smaller dictionaries in a cost-effective manner. 


\subsection{Historical overview}

The Eastern Cape, in particular the Victoria East subregion, is the cradle of all growth and development in relation to isiXhosa. It was here that the language was first committed to writing. It was also here that the first printing press in South Africa was acquired specifically for the printing of works in isiXhosa. And it was here that the first authors of isiXhosa literature were concentrated and it was also here that the first attempts at compiling isiXhosa dictionaries were made.

The Xhosa Dictionary Project was started in 1968 as a project of the University of Fort Hare under the late Prof. H.W. Pahl as its director and editor-inchief. It was in response to the needs of students of the isiXhosa language for a modern, definitive, scientific standard dictionary. The dictionary entitled the Greater Dictionary of Xhosa is a comprehensive trilingual dictionary. Its headwords are entered and defined in isiXhosa and then translated into English and Afrikaans. It also has fifty-two addenda containing information on grammatical, historical, anthropological and cultural aspects of isiXhosa.

It is divided into three volumes, namely Volume I with words belonging to letters A to J, Volume II with words under $\mathrm{K}$ to $\mathrm{P}$ and lastly Volume III with words starting from $Q$ to Z. In 1989 Volume III was published. The reason for starting with this volume was due to the fact that the sponsors were anxious to see some tangible results of their contributions. Therefore the then editors decided to publish the third volume, whose contents was more organised and ready for publication than that of the first two volumes. The two other volumes are still in preparation.

This project is the largest and most established lexicographic project not only for isiXhosa, but also amongst the other African languages of South Africa. It caters for the needs of both academic and ordinary language and dictionary users. Also of importance is the project's experience in compiling the largest most inclusive dictionary in an African language in South Africa. As a result of this, the project can serve as a ready model for the establishment of new lexicography projects or the growth of already established projects in other African languages.

\subsection{Funding}

While the University of Fort Hare assumed the major financial responsibility from its inception, the project was as well supported by the Human Sciences Research Council of the Republic of South Africa, the governments of the former Republics of Ciskei and Transkei, and the Anglo-American and De Beers Chairman's Fund. It also received a generous publication grant from the then Department of Education and Development Aid of the Republic of South Africa. 


\subsection{Data gathering and editorial process}

Data was collected through field research and by the perusal of written material. It must however be mentioned that $A$ Kafir-English Dictionary (1915), written by $\mathrm{A}$. Kropf and R. Godfrey and also Godfrey's unpublished manuscript, which was an attempt to revise $A$ Kafir-English Dictionary, were also major sources of entries. This data was then recorded on cards and an alphabetic arrangement of entries was done manually. Each entry occurred on a short card, in ordinary paragraph form and also on a long card, in which the three languages, isiXhosa, English and Afrikaans, were arranged in this order.

The use of a computer was first introduced in the project at the beginning of 1989 when the director and editor-in-chief Prof. B.M. Mini came into office. During this time the first computer typist started typing entries on the computer from the long cards, using the word-processing program called XyWrite III Plus, version 3,54. However, the card system delayed the progress and consequently the publication of the rest of the dictionary.

\section{The present situation}

\subsection{The functions}

To achieve the already stated aims, the project is performing the following functions:

- It is collecting, processing, recording and storing vocabulary items of isiXhosa and its various dialects.

- It acquires by various means, including translation, accurate English and Afrikaans equivalents for the isiXhosa items.

- It does lexicographic editorial work on the collected data.

- It collects, stores and records in addendum form, anthropological and cultural information relating to some of the entries of the dictionary.

- It offers translation services for the local community, both provincially and nationally.

\subsection{Compiling and editing}

All the editors have personal computers and are computer literate. Entries are no longer recorded on cards. To accelerate the editorial process, the card-based database is being converted to an electronic database. Many of the problems peculiar to isiXhosa lexicography have already been solved. Complications caused by the trilingual format of the dictionary have also been addressed. 


\subsection{Management of the Project}

Two committees serve as facilitators for the affairs of the project. These are the Xhosa Dictionary Advisory Committee and the Xhosa Dictionary Executive Committee. The membership of the Xhosa Dictionary Advisory Committee has a representative from each of the sponsoring organisations and bodies, one each from the University of South Africa, the University of Cape Town and Rhodes University, and the manager of the Lovedale Press who represents the Church of Scotland. Internal members are the director and editor-in-chief of the project, the Rector of the University of Fort Hare, the head of the African Languages Department of the University of Fort Hare and the Council representative also from the Department of African Languages. The Xhosa Dictionary Executive Committee consists of all the internal members of the latter committee, as well and the Lovedale Press representative.

\subsection{Staffing}

The project has five full-time editorial staff members, and one temporary administrative secretary.

The editorial staff consist of the director and editor-in-chief, two editors and one assistant editor for isiXhosa, and an assistant editor for Afrikaans.

\subsection{Present funding}

The furiding of the project has until now been the responsibility of the University of Fort Hare. The University is entitled to make all or part of its contribution to the funding of the project by the establishment and maintenance of posts within the project and by the provision of office space and other necessary services for the project.

All funds raised by the project or donated to the project are kept in an account within the financial administrative system of the University of Fort Hare. Such funds are managed in terms of the University of Fort Hare's financial accounting procedures. The University of Fort Hare auditors usually audit the accounts annually.

\subsection{Accommodation}

The Xhosa Dictionary Project is situated on the campus of the University of Fort Hare, with eight offices, including a strongroom. The office space can easily be extended to accommodate more staff, should the need arise. The strongroom stores the project's archival material, namely the short and long cards arranged alphabetically, computers and other valuables. 


\subsection{Computer Support Services}

The project has sufficient hardware for its present needs. However, an uninterruptible power supply, and a flatbed scanner and tape-streamer back-up system would be welcome additions.

As far as software is concerned, the project is in the process of converting from a word processor to a database. A number of database options are being evaluated. All the members of staff of the project are on e-mail. It is therefore easy for lexicographers from other units to make contact with the members of the Xhosa Dictionary Project.

\subsection{Relations with outside organisations}

Since the Greater Dictionary of Xhosa is trilingual, it contributes to the realisation of multilingualism.

Channels of communication and co-operation between the project and a large section of the South African community, as well as other lexicographic centres in South Africa, are already open.

Members of the staff of the project are affiliated to and are regular participants of the following professional organisations: the American Association for Lexicography, the African Languages Association of Southem Africa, the South African Folklore Society and the South American Translators Institute.

\subsection{Lexicographic Research and Training}

The interest in the production of dictionaries in South Africa presented an opportunity for this project, with its experienced staff and large collection of processed data, to develop courses in lexicography, incorporating the metatheory of compiling dictionaries in the African languages.

At present, staff members are involved in the study of the phonetics of isiXhosa, in the writing of a specialised Xhosa Bible Dictionary and in management studies. As one of the modern pioneers in the field of lexicography, the project has shown itself capable of assisting new lexicography units in African languages, as well as helping aspiring lexicographers to start their projects. In this regard, acquired skills of lexicographic strategic planning and management among other things, will enable the staff of the project to offer these important services. The project staff continually upgrade themselves in the field of lexicography by attending courses at the Bureau of the WAT and at SALEX. 


\title{
Zulu Dictionary Project
}

\author{
A.C. Nkabinde, Project Leader, Zulu Dictionary Project, University of \\ Zululand, Umlazi Campus, Isipingo, Republic of South Africa
}

\section{Aims and objectives}

The aims and objectives of the Zulu Dictionary Project can be summarised as follows:

- In the first place, to make a Zulu explanatory dictionary accessible to the speakers of the Zulu language and the public at large.

At the commencement of the project, no explanatory dictionary existed in Zulu. The need was obvious for social, educational, economic, technical, scientific and other purposes. The slow development of Zulu can largely be ascribed to the lack of explanatory dictionaries, which lead to a loss of confidence by the native speakers in the ability of Zulu to meet new demands and challenges. Anxiety, fear and doubt are created in the minds of the users of Zulu as to its capacity and suitability to meet new situations. This lack of confidence can be ascribed to the uncertainty as to the exact meanings of words, the correct use of words, and so forth.

- In the second place, to develop skills, to arouse interest, and to create a vocabulary for the definition of entries in the field of lexicography.

Lexicographic work requires appropriate tools. It is not sufficient to use synonyms or other known words to define entries to dictionaries. Definitions require a systematic, consistent and insightful treatment of entries. These must pervade the entire work. The use or creation of generic terms as a base of a definition could enhance the quality of definition. This calls for a critical evaluation of all definitions in order to excite and kindle the users' interest and imagination. The making of dictionaries is creative work. It is not a mere cataloguing of words.

- In the third place, to establish a database for linguistic research.

A dictionary is a good source of words, derivations, idiomatic usages of words, proverbs and other forms. It is a good facility for studies of phonology, phonetics, morphology and syntax. Above all it provides an excellent source for the study of semantics.

- In the fourth place, to provide an authoritative source of reference.

Ideally a dictionary serves as an arbiter to resolve differences in the interpretation of meaning. Since every lexicographer aims to produce a 
comprehensive definition of lemmata, entries in dictionaries are generally regarded as authoritative.

- In the fifth place, to record changes in the vocabulary of a language.

All languages are dynamic. They constantly incorporate new items of vocabulary. New vocabulary items include coinages and borrowings. Consequently, it is imperative to include the established, new vocabulary in the language. Obsolescence of words is also part and parcel of the existence of a language. Obsolete words deserve to be retained in a dictionary as they are indispensable in the study of historical linguistics and etymology.

- In the sixth place, to reinforce the definition of entries of flora and fauna.

Up till now many entries of flora and fauna are not adequately defined in the existing Zulu dictionaries. Comprehensive definitions of flora and fauna need to be given. The incorporation of botanical and zoological scientific terms in the entries will enhance their value.

- And lastly, to fulfil an educational need.

It is common knowledge that a dictionary is a learning aid. It fulfils a far greater need than simply providing meanings of words. It inculcates a habit of searching for and evaluating information and utilising it in a variety of new contexts. This contributes immensely to the development of independence in the use of information by the consultant of a dictionary.

\section{The History}

The Zulu Dictionary Project commenced on 1 December 1977. This was the first endeavour to produce an explanatory dictionary in Zulu. The project was started without a budget and without any provision for staffing. Three students were initially employed on an hourly rate and paid out of savings from the budget of the Department of African Languages.

In 1981, the Department of Education and Training approved the establishment of posts at lectureship level. Secretarial work for entering definitions on the computer was arranged on an ad hoc basis. The staffing position has not changed. It has accordingly not been possible to accelerate the tempo of work and embark on field work. The project leader was not able to devote much time to the task as he was involved in the administration of the University of Zululand for a considerable time.

Up till now, two publications, Isichazamasu 1 and Isichazamasu 2 in 1981 and 1985 respectively, have been produced by A.C. Nkabinde for use in schools. A more comprehensive version of this series was printed in 1998. 
Zulu lexicography dates back to 1857 with the publication of $A$ Zulu/Kaffir Dictionary by J.L. Döhne. This was followed by J.W. Colenso's Zulu/English Dictionary, A.T. Bryant's Zulu-English Dictionary, R.C.A. Samuelson's King Cetshwayo Dictionary, P.W. Wanger's Konversations-Grammatik der Zulusprache, ZuluEnglish Dictionary by C.M. Doke and B.W. Vilakazi, Woordeboek Afrikaans-Zoeloe Zoeloe-Afrikaans by A.M. Dekker and J.H. Ries and English and Zulu Dictionary by C.M. Doke, D.McK. Malcolm and J.M.A. Sikakana in 1958. Altogether eight major bilingual dictionaries existed when the Zulu Dictionary Project commenced its task. Many of these pioneers worked individually, on their own, without secretaries and without computers. But they did exceptionally good work. Subsequently, Afrikaans/Zulu Woordeboek met Engelse Vertalings by Ernst Kotzé and Patrick Wela and a monolingual Zulu dictionary, Isichazimazwi Sanamuhla Nangomuso by Sibusiso Nyembezi, have been produced respectively in 1991 and 1992. This is a good trend. There should be five, ten or fifteen dictionaries as is the case in many developed languages. One dictionary is not enough.

\title{
3. The current situation
}

The project has been battling to obtain financial assistance since its inception. It requires the services of at least two full-time workers and a full-time officer to capture data on the computer on an ongoing basis.

A major aspect of the dictionary encompassing the definition of flora and fauna had to be shelved because of lack of staffing. Similarly, it has not been possible to incorporate much new vocabulary because field work is necessary to gather information. The investigation and testing of vocabulary items from various geographic regions through field work had to be sacrificed. This means that important dialectal forms are lost.

\section{The State of Lexicography in Sesotho}

\author{
M.A. Moleleki, Department of African Languages, University of the Orange \\ Free State, Bloemfontein, Republic of South Africa
}

\section{Demographics}

Sesotho is a language spoken by $\pm 2,23$ million people in South Africa and by $\pm 1,98$ million people in Lesotho, giving a grand total of 4,21 million Sesotho speakers in the two areas. Of the 2,23 million Sesotho speakers in South Africa only about a million reside in urban areas. It can be accepted that more than $50 \%$ of the so-called urbanized Sesotho speakers function most effectively in Sesotho. If it is borne in mind that most of the nonurban Sesotho speakers hold 
their language in high esteem, it can be concluded that more than 1,3 million people in.South Africa need the Sesotho language for their day-to-day communication.

Furthermore, of the 1 million urbanized Sesotho speakers, the probabilities are that not more than 10 per cent is fully competent in a language other than Sesotho. If this estimate is correct, then $80 \%$ of the Sesotho speakers need their language for their survival.

The reasons for referring to statistical data are twofold. Firstly, it indicates that the majority of Sesotho speakers is not at all alienated from their language, and, secondly, it shows that the speakers rely heavily on their language for their effective functioning. The question can now be asked: how effective is the Sesotho language in addressing the needs of its speakers?

\section{$2.1 \quad$ Exotic Influence}

An earlier way of life has passed, and will never return. Modernization by way of industrialization, scientific and technological advancement, new ideas, concepts and philosophical thought pervades the world. To Sesotho speakers, modernization has always been exotic, both in terms of origin and expression. The initial providers of modernization were the French missionaries. Their influence is evidenced by nonnative Sesotho words such as pompong and potlolomente, loaned from the French words bon-bon and portmanteau respectively.

When Lesotho came under British rule, it was the turn of English to make its impact felt on Sesotho. Small wonder adoptives such as tjhentjha (to change) and joko (yoke) are used. The establishment of the Orange River Sovereignty (later known as the Orange Free State) led to coexistence between the Basotho and the Afrikaners. And it is no exaggeration to observe that no other nonSesotho language infiltrated Sesotho the way that Afrikaans did.

These influences stress the fact that from earliest times the linguistic situation in Sesotho has always been fluid, responding both to innovations and the new linguistic environment. The language never waited for either language experts or language practitioners to deliberate over its fate. It made and continues to make strides despite the intransigence of language purists.

\subsection{Sesotho Language Family}

It is necessary to place the term Sesotho in perspective, for this will have implications for the modus operandi of lexicographic projects. Sesotho is said to belong to the same language group as both Setswana and Sepedi. However, the said languages in fact share a common ancestor in the person of Malope, a Mohurutshe chief who broke away from the Barolong somewhere around Ethiopia during the 13th century. The three Sesotho languages should be seen 
as a family with a common origin rather than a language group based merely on shared affinities.

The gist of the argument is that a separatist approach to lexicographical research in the three languages will be as unfortunate as it would be undesirable. Closer co-operation among the three could yield far better results than at present. Of course this does not exclude closer ties among indigenous African languages per se. Also, differences that exist among the Sesotho languages should not be ignored.

The scenario sketched thus far illustrates how Sesotho, without the intervention of linguistic theoreticians, adapted and responded to changing circumstances from the very early stages of modernization.

\subsection{Early Lexicographic Activities}

With the foregoing constituting the background to this report, there can now be focused on the state of Sesotho lexicography. (Here the preparatory work done by Mr T.W.D. Mohapi must be acknowledged.)

The most important dictionary that can be mentioned is Adolphe Mabille's Sesuto-English Dictionary, published in 1876 at Morija in Lesotho. The work consisted of 158 pages. It came into existence in response to the missionaries' need to translate the Bible into Sesotho as well as to enhance effective communication with the Basotho. The dictionary underwent several revisions. The fourth edition appeared in 1911 . This was enlarged by $\mathrm{H}$. Dieterlen of the French mission. It now contained 20000 words. In 1959 a reclassified, revised and enlarged edition by R.A. Paroz appeared. The dictionary is also available in the Sesotho orthography of the Republic of South Africa. Today this revision of more than thirty years ago continues to be the most useful and consulted work in Sesotho. It is for this reason that there should be dwelt at length on the nature of this work.

- As the name suggests, the dictionary is bilingual. Sesotho terms appear first and then their English translation equivalents.

The form of this dictionary reflects its initial thrust. Since the intended target audience of the missionaries was Sesotho-speaking, the missionaries first had to understand Sesotho before they could reach their converts; and the newly converted had to learn to express themselves in the language of the new faith so as to demonstrate that they were of a calibre different from that of the non-Christian stock - that they were educated and civilized.

And, also manifest in the structure of this very first Sesotho dictionary, is the erroneous impression created, be it by accident or design, that seemingly obscure Sesotho signifiers can only be explained in terms of English equivalents. The impression is created that Sesotho is incapable 
of self-explanation. Hence the practice of teaching Sesotho through the medium of English, or any other language for that matter.

- The dictionary is semilinguistic in nature. Only the sense and phonological features of words are to a certain extent considered, whereas the syntactic characteristics are completely ignored.

- The entries are arranged alphabetically in so far as the etymology of Sesotho terms is concerned. Thus the work is not user-friendly. It is structured by the presupposition that the user is very conversant with the structure of Sesotho. This implies that one looks up a lexical item one already partly knows by being familiar with its genesis. Needless to say, the dictionary is not meant for learners but for those who already have a sound competence in the language. The mere fact that only English translation equivalents are given rather than descriptions of the Sesotho lexes, seems to be based on the assumption that the user is steeped in English. English explanations are given only where a single English term equivalent for the Sesotho one cannot be found. The bilingual nature as well as the etymological bias of the dictionary largely favours a fully bilingual user. Furthermore, the synchronic nature of language is sacrificed at the expense of diachrony.

- The work is as comprehensive as it might be expected, given the circumstances surrounding its conceptualization. As indicated earlier, it was Christianity-oriented in its initial thrust. Subsequent editions only incidentally embraced the general world of the Basotho, especially their new work-places, the farms and the mines, as well as the cultural artifacts of the encroaching culture.

- It should be taken into account that the work was conceived and published during the 19th century and its subsequent revisions are almost as obsolete as the founding project itself.

In addition to the Sesotho-English Dictionary, there is L. Hamel's English-Southern Sesotho Dictionary published by the Catholic Centre of Mazenod in Lesotho in 1965. This work is very similar to Paroz's edition in terms of both substance and structure.

Whilst modernization has permeated the Sesotho-speaking people's entire lives, the conscious adjustment of Sesotho to this state of affairs has been both sporadic and haphazard, lacking in co-ordination and synthesis. A work that readily comes to mind under this category is A. Casalis' English-Sesutu Vocabulary published in 1894. It went through many editions. At leasi Casalis should be credited for his honesty: he makes no false claims to having written a dictionary. True to its name, the work is nothing else but an alphabetically arranged list of English words with their Sesotho counterparts. The reasons for selecting the words included in the vocabulary remains unclear. One might only hazard a guess that Casalis had to communicate in Sesotho the concepts and ideas embraced in the English terms. 
Although Casalis' work might not be worthy of the term dictionary as its title also reflects, it nevertheless begins to address a very pressing need in Sesotho and perhaps in other indigenous African languages as well. Since Sesotho has been left far behind in the advance to modemization, it presently lacks the capacity to express modern ideas and concepts. Thus the need for bilingual dictionaries based on English and for rendering Sesotho translation equivalents together with Sesotho definitions, has become more compelling than ever before. Stated differently, there was in the past and there exists today an urgent need for translation dictionaries in Sesotho.

\subsection{Language Committee / Language Board}

A series of Sesotho terminologies compiled over the years from 1954 to 1992 under the auspices of the then Department of Education and Training, should be viewed as attempts to address the problems faced by translators in fields as diverse as education, health and media. The Sesotho section of the South African Broadcasting Corporation also made its contribution. It used to have its own subcommittee working on terminology. These terminology lists were submitted to the Sesotho Language Committee which later became known as the Sesotho Language Board.

A few comments on the modus operandi of the Language Committee/ Language Board vis-à-vis terminology lists will suffice.

There was never any attempt to classify the terminology to be translated into its various fields of knowledge. Consequently, it rarely occurred to members to obtain certain kinds of expertise before attempting their own translations. Virtually all terminological areas were covered.

- No attempts were ever made to lay down guiding principles for the task at hand. Each term was not only seen as different from the rest, but also as unique, requiring a unique approach. Hence the work lacked both coherence and cohesion.

- The Committee sat for a period not exceeding eight days in one calendar year. And terminology was not its sole responsibility - it had other business such as the evaluation and prescription of literary texts. In this way the Committee never had sufficient time to concentrate on the intricacies of lexicography. It often happened that words had to be coined on the spur of the moment.

- There were no mechanisms in place to test the acceptability or not of the coined words among target users.

The then Language Boards operated under extremely difficult conditions. And, with the best of intentions on their part, their end products were inherently flawed. Nevertheless, they played a significant role by fulfilling a deeply-felt need. In short, these terminology lists warrant serious re-evaluation. 


\subsection{Individual Projects}

Projects were undertaken by individuals and by certain institutions.

J.A. du Plessis, J.G. Gildenhuys and J.J. Moiloa produced Bukantswe ya maleme-Pedi: Sesotho-Seafrikanse/Tweetalige Woordeboek: Afrikaans-Suid-Sotho in 1986. This dictionary consists of three parts. The first part contains Sotho terms with Afrikaans explanations, the second proverbs and common phrases in Sotho translated into Afrikaans, and the third Afrikaans terms with Sotho equivalents. Another publication is the Dictionary of Basic English: Southern Sotho edited by K.B. Hartshorne and published in 1984. This dictionary has two sections. The first section consists of English terms with different usages; the second part contains Sesotho equivalents corresponding to the English terms. Both these works could be regarded as dictionaries for learners, especially second-language learners.

Recently, in 1991, the Reader's Digest Association published a Multi-Language Dictionary written in seven languages. In fact, this is not a dictionary as the title purports, but a multilingual terminology list.

Work is also being done by the language unit at the Soweto Campus of the Vista University and by the Centre for Legal Terminology in African Languages at Sunnyside in Pretoria. These ventures require better co-ordination with other undertakings through networking.

The only Sesotho monolingual dictionary is the one written by F.Z.A. Matsela, and published by Macmillan Boleswa (Lesotho) in 1994. Its title is Sehlalosi: Sesotho Cultural Dictionary. As the name suggests, it focuses on a specific sphere of life, viz. culture. The Sesotho terms are further classified into subcategories such as the upbringing of children, songs and praises, religion and marriage, etc.

The terms are arranged alphabetically. The entries are based on the synchronic nature of the lexical items rather than on their historical roots. A descriptive approach was followed whereby each term is explained in Sesotho and its different nuances of meaning brought to the fore.

The author makes no pretence at exhausting the cultural field of the Basotho and yet his contribution is an eye-opener. Besides indicating possible future research directions, it caters for the needs of both learners and speakers of Sesotho. The work is also handy for researchers. Above all, it is userfriendly.

However, the dictionary does not provide information on for example tonology, etymology and syntax.

\section{The Road Ahead}

From the above overview of the state of lexicography in Sesotho, it becomes clear that Sesotho is in dire need of a monolingual dictionary, a dictionary which will affirm the status of Sesotho as a language whilst contributing towards the formation of a healthy mindset within the Sesotho personality. 
However, such a project should be seen as a long-term undertaking because of its magnitude and complexity. For medium- to short-term purposes it is necessary to work on:

- multilingual terminology lists, translating specifically from English to Sesotho. Such endeavours could alleviate the need for translation strategies.

- technical and specialized dictionaries, particularly in areas such as health, law and technology. The actual prioritization will be a matter of detail.

However, these medium- to short-term strategies should be seen as calculated strategies towards the ultimate goal - a Sesotho dictionary. The development should be from terminography to lexicography.

What is more, lexicography has grown into a demanding discipline with its own principles and considerations. Thus, for the envisaged projects, manpower exposed to the modern operational principles of lexicography is needed. People who can first exhaust the capacity of the Sesotho language before coining new terms are needed. Possibilities presented by linguistic permutations such as derivations, compounding, broadening of the semantic range as well as blending should be exploited to the full. A good mastery of the source language is also crucial.

Computer technology is one skill to be fully utilized. This will also enhance networking with possible resource instances.

\title{
5. Concluding Comment
}

Whilst dictionary-making is a highly sophisticated technical exercise, it is also one of the few opportunities where the indigenous speakers of a language have to be granted the right to take full control of their destiny. If tutelage becomes absolutely necessary, it should be at the language owners' discretion.

\section{The State of Lexicography in Setswana}

\author{
M.R. Malope, Emeritus Professor, Department of Setswana, University of the \\ North West, Mafikeng, Republic of South Africa
}

\section{Introduction}

Setswana as a language is used in the Republic of South Africa (where it enjoys official language status), Botswana (official language), Namibia (taught in schools up to Standard 4 only) and the South Western parts of Zimbabwe (where it is merely a means of communication and used sporadically). 


\section{Efforts at compiling Setswana dictionaries over the years}

The need to have a Setswana word-list and some sort of dictionary was felt very early in the contact situation between the Batswana and various groups such as missionaries, adventurers, colonists and later settlers and government and administrative officials in those areas inhabited by the Batswana.

In 1830 Robert Moffat published a Setswana version of the Gospel of St Luke, and at the back offered two pages of explanations of the more "difficult" words. These explanations can be regarded as the first small start of a Setswana dictionary. In the years following, Moffat, Edwards, Ashton, Hughes, Livingstone, Price and others produced word-lists as they worked on their translations and publications.

The first recorded published dictionary in Setswana, entitled Lokwalo loa Mahuku a Secwana le Seeneles, was compiled by Revd John Brown of the London Missionary Society in 1875-1876. This is a bilingual dictionary which consists of two sections, viz. a Setswana-English section (130 pages) and an EnglishSetswana section (145 pages). A second edition of this dictionary appeared in 1895 and was reprinted in 1914 and 1921 . The third edition was published in 1925 (in the orthography agreed upon in 1910) under the guidance of Revd J. Tom Brown and appeared under the title Setswana-English Dictionary. The third edition with a new preface appeared in 1965 and was reprinted in 1968, 1973, 1978, 1979, 1980, 1982 (twice), 1985, 1986 and 1987.

The fourth edition under the title Setswana-English-Setswana Dictionary was edited by Z.I. Matumo and was published by Macmillan Botswana in 1993. A Setswana orthography very close to the one current in the Republic of South Africa is used.

In 1976 Thanodi ya Setswana ya Dikole appeared under the editorship of Morulaganyi Kgasa, published by Longman Botswana. It was the first monolingual dictionary in Setswana prepared with schools as the target market. It consists of 125 pages.

J.W. Snyman, assisted by J.S. Shole and J.C. le Roux, edited the Dikisinare ya Setswana English Afrikaans Dictionary/Woordeboek published in 1990 by Via Afrika, the first trilingual dictionary in which Setswana featured. This dictionary prides itself on being rich in the vocabulary of Setswana "traditional life, botany, zoology, anthropology and ornithology".

Thanodi ya Setswana appeared in 1995 under the coeditorship of M.L.A. Kgasa and J. Tsonope, published by Longman Botswana. It can rightly be regarded as the successor of Morulaganyi Kgasa's Thanodi ya Setswana ya Dikole of 1976, and consists of 330 pages - the second monolingual dictionary in Setswana. This dictionary uses the present 1980 Botswana orthography, and also includes dialectal variants.

A Setswana monolingual dictionary project was started in 1984 at the Institute of African Studies, University of Bophuthatswana (now the University 
of North West), with J.M. Ntsime as editor up to 1987. From 1988 to 1995 D.M. Mothoagae was the editor, assisted by M.H. Zebediela, P.M. Rakgokong and T.J. Mabe. The first edition of this dictionary, to be entitled Thanodi ya Setswana, has been completed and is in the process of publication.

\section{The future}

These dictionaries are all useful in varying degrees to users of Setswana, depending on the individual's specific needs. However, they do not represent an exhaustive record and description of the Setswana vocabulary. A great deal of effort is still required to register the words that have appeared in various books and publications of Setswana, as well as words that are used in the context of various industrial activities such as mining and the manufacturing sectors. Setswana also needs a record and description of the Setswana vocabulary in the various fields of scientific study.

Efforts are afoot to establish a Setswana Language Body that will play a role in the process of establishing a Setswana Lexicographic Unit. So far, stakeholder organizations such as the Setswana Writers Association (Magopo), Setswana Association (representing teachers, lecturers, translators and the organised students in Setswana), the Setswana Bible Translators, the Bureau of Setswana Language and Culture and the Setswana Academic have expressed support for the establishment of a lexicographic unit for Setswana.

\section{The States of siSwati Lexicography}

\section{P.M. Lubisi, Department of African Languages, University of Zululand, KwaDlangezwa, Republic of South Africa}

\section{Introduction}

SiSwati belongs to the Nguni group of languages and is therefore closely related to Zulu. It is spoken and written in Swaziland and in the Republic of South Africa, especially in Mpumalanga. According to statistics, about $70 \%$ of the population of Mpumalanga is siSwati-speaking. In 1968 it became the national language of Swaziland, and in 1976 it was introduced as an official language in the former KaNgwane Swazi homeland. There has been close cooperation between the Swazis in the Republic of South Africa and those in Swaziland to develop siSwati as an official language. Before the South African Language Board for siSwati stopped functioning in 1996, joint meetings were regularly held with the Language Board of Swaziland. 


\section{Existing siSwati Dictionaries}

The first publication that can be called a dictionary is SiSwati Orthography, Terminology and Spelling Rules which appeared in 1980. This was followed in 1981 by the publication of D.K. Rycroft's Concise siSwati Dictionary (Pretoria, J.L. van Schaik). Research facilities for producing this dictionary were provided by the School of Oriental and African Studies at the University of London. The dictionary consists of two bilingual sections: the SiSwati-English part comprises 111 pages and the English-SiSwati part 73 pages. Because of its limited coverage and small size there are no illustrative examples, no special usage notes and no synonyms.

The first matriculation paper in siSwati was only dispensed in 1987. For years Swazis were compelled to study Zulu, which in practice hindered the progress and development of siSwati. Private schools situated in siSwatispeaking areas still prefer teaching Zulu instead of siSwati. Nevertheless, from 1976 onwards significant achievements were made in siSwati literature and textbooks, so that at the moment siSwati is offered as a degree subject by the University of South Africa and the University of Zululand.

SiSwati is still much neglected in the communication media. It does not appear in the SABC-TV news logo. Some of the announcers on the radio are not mother-tongue speakers of siSwati, which causes frustration among listeners of the siSwati radio Ligwalagwala. There is also little awareness of siSwati among the business community who prefer Zulu names for their businesses in spite of the fact that they are situated in siSwati-speaking areas.

\section{Conclusion}

SiSwati is in need of dictionaries of every kind: a monolingual dictionary, school and standard translation dictionaries, thesauri, idiom and proverb dictionaries, technical dictionaries, usage guides, etc. It is essential that siSwati lexicographic projects should be undertaken along with the development of the language itself. Dictionaries will certainly enhance pride and interest in the language. 


\title{
The State of Tshivenda Lexicography
}

\author{
A. Mawela, Northern Province Education, Arts, Culture and \\ Language Services, Pietersburg, Republic of South Africa
}

\section{Introduction}

The speakers of Venda are found mostly in Venda in the Northem Province, although some are found in other provinces, such as Gauteng, and a few in Mpumalanga, the Free State and North West Province, as well as in Zimbabwe.

\section{Existing lexicographic works in Venda}

Little has been done in the lexicographic field in Venda. At present there are only a few Venda dictionaries, all of them translating dictionaries, namely the Tshivenda-English Dictionary by N.J. van Warmelo published in 1937 by the Government Printer, Pretoria, and revised with the help of W.D.M. Phophi and published in 1989 as Venda Dictionary Tshivenda-English by J.L. van Schaik, Pretoria, the Trilingual Elementary Dictionary by P.J. Wentzel and T.W. Muloiwa, published in 1976 by the University of South Africa, Pretoria, and revised in 1982, and the Dictionary of Basic English: Venda by K.B. Hartshorne, published in 1984 by Educum, Johannesburg. The trilingual dictionary concentrates on words in common use in Venda, translating them into Afrikaans and English. In the foreword the authors comment on the lexicographic needs in Venda:

This work must be seen as a very modest attempt at complying with an urgent need ... It was found necessary to commence with compiling a preliminary work in the light of the fact that no Venda dictionary is available at present (Wentzel and Muloiwa 1976: xi).

There is another dictionary which has not been published yet, although it was completed several years ago. The title is Thalusa maipfi a Tshivenda (An Explanation of Tshivenda Words) by M.E.R. Mativha, N.A. Milubi and R.N. Madadzhe. The manuscript of this dictionary consists of three volumes: Two volumes contain Venda to English and one volume contains English to Venda concepts.

However, the printing of this massive work is long overdue. It would appear that publishers are not prepared to invest their money in publishing works which they believe will not generate any proceeds. Obviously it is presumed that very few people will be interested in buying a dictionary of this nature. This dictionary, however, is more up-to-date and treats a wide variety of concepts. Most of the terminology was collected from the Language Services Division. 


\section{Necessary lexicographic works}

\subsection{Subject (technical) dictionaries}

There is still a lot of work to be done in Venda in order to bring the language on par with other languages. Research work done so far has not resulted in different subject dictionaries such as medical, agricultural, economical, accounting, commercial and legal dictionaries.

In compiling subject dictionaries, researchers need to consider the figurative language used by traditionalists. Such special references are mostly found in medical or biological concepts. In most cases figurative concepts are utilised to avoid using the exact words which are regarded as taboo in Venda. A euphemism is for instance used if a woman fails to conceive. For example, "Musadzi uyu nowa yawe a i fari" which means, literally translated, "This woman, her snake does not hold or catch".

This way of expression is peculiar to Venda speakers, but it would not make sense to people who speak Venda as a foreign language. The figurative language which is commonly used in Venda has often resulted in people being treated or punished wrongly because of a lack of literature explaining such concepts. People have often been misdiagnosed in doctors' consulting rooms due to a lack of mother-tongue translators of Venda. For example, an old lady who says to the doctor "Ndi na mulenzhe", literally translated as "I have a leg", actually means "My leg is sore or painful". In courts people have been sent to jail for crimes they did not commit due to a misconception of words by interpreters who are foreign speakers of Venda. For example, an old lady was asked if she really did what she was accused of. She responded sarcastically saying "Nazwino", translated as "Of course". Yet the tone she used meant "No, I did not do it." Much as the concepts have to be taken into consideration, so also the tonal system existing in the language.

This shows the urgent need for idiomatic dictionaries in the language. This also indicates the need for research at grassroots level, where ordinary people have to be consulted.

\subsection{Dialectal (general) dictionaries}

Thorough research on different dialectal forms has to be undertaken, for there is a tendency among Venda speakers to reject certain words which they regard as borrowed. This retards the growth of the language. Venda speakers should stop looking upon the so-called standard dialect as the only correct dialect. All languages are at one stage or another influenced by languages with which they come in contact, for example the absorption of concepts such as "lobola" in English. 
In his book $A$ Linguistic Analysis of Venda (Pretoria, Via Afrika), George Paulos (1994: 8) echoes the notion that dialectal forms contribute to the growth of a language:

These speech differences that arise within a language may be due to various factors, for example, and this happens very often, the speech of a group is influenced by the language of an adjoining area, and as a result certain sounds or words of that language begin to creep in over a long period of time. These innovations then become established within that group and become part of their own language.

The standard dialect Tshiphani which the speakers of Venda recognise as the only correct dialect to be used, was first introduced by the missionaries in the area where the speakers of Tshiphani are concentrated. In his unpublished M.A. thesis The Toneme Patterns of the Venda Noun (Pretoria, University of South Africa), M.E.R. Mativha (1966:5) states:

This is the orthography in which the Bible and all Venda literary works are written. This orthography has remained stable for many years with only slight changes.

He also mentions that it was used by the Berlin Missionary Society in its church literature.

In addition to the dialectal variety in Venda, there is also the special way of speaking about royal families. For example: A chief does not drink from an ordinary calabash, called "khavho", but from a "ngwena", meaning "crocodile". A chief does not die like ordinary people for whom "u fa" is used, but he is compared to a lake which has gone dry: "mativha o xa".

When compilers take other dialects into consideration, monolingual dictionaries which define concepts of dialects in different areas will be made possible.

\section{Research work to be done}

Extensive research has to be done in different fields in order to keep pace with other advanced languages.

\subsection{Translation}

Translating dictionaries in other languages could be one way of meeting the lexicographic needs of Venda. New lexical items should be adopted as they are, with only a change in the spelling form which will follow the spelling rules of the translating language, in this case Venda. For example: tshitofu "stove", or vhurotho "bread". 


\subsection{Grassroots research}

Research has to be conducted at grassroots level, where researchers go out and actually mix with people from all ranks and walks of life to collect the latest concepts. For instance, researchers should go to sports fields, shebeens and different social gatherings where people use language in a relaxed and recreational atmosphere.

\subsection{Introduction of columns in newspapers}

A column in one of the national newspapers which introduces new concepts in different languages would help all South Africans to learn each other's languages and also to add to the growth of lexical items of the languages. This would familiarise speakers of other languages with Venda.

\section{Conclusion}

Stakeholders in the Venda language, who are probably not only Venda speakers, but hopefully all South Africans, should start researching to enable the growth of the language and close the wide gap which was created over a long period of slow development.

\section{The State of Xitsonga Lexicography,}

\section{D.I. Mathumba, Department of African Languages, University of South Africa, Pretoria, Republic of South Africa}

\section{Introduction}

It is possible to speak of lexicography only when a writing convention has been developed in a language. The Vatsonga are indebted to the missionaries of the Mission des Eglises Libres de la Suisse Romande, which later developed into the Mission Suisse dans l'Afrique du Sud, commonly known as the Swiss Mission in South Africa, for the conversion of Xitsonga into a written language. In July 1875 Revd Ernest Creux and Revd Paul Berthoud arrived in the then Northern Transvaal, which is today the northern part of the Northern Province, and settled at Valdezia. They immediately embarked on the immense task of committing Xitsonga to writing, but it was not until 1883 that the first publication, namely Buku ya TŠikwembo tŝin'we na Tisimo ta Hlengeletano, both Bible and hymns of the congregation, was published. 


\section{The emergence of Xitsonga dictionaries}

What could be regarded as the first dictionary in Xitsonga is a word list published by W.H.I. Bleek in 1856 under the heading "Lourenzo Marques" which was used because he was trying to give a word-list of the languages spoken around Lourenço Marques, the present Maputo in Mozambique. From this list one can extract those words which are Xitsonga. Among others there are tinyanyana "bird", fole "tobacco", dzana "hundred" and tandza "egg". A very interesting one is galloway for "pig". This was an attempt to put nguluve into writing.

The first Xitsonga dictionary was published in 1907. This was the pocket dictionary Tsonga / Shangaan / English - English / Tsonga / Shangaan, by the Revd C.H.W. Chatelain. Its second edition appeared in 1909. The current revised and enlarged sixth edition of the work is the English/Tsonga-Tsonga/English Pocket Dictionary, published in 1974 by Sasavona Publishers and Booksellers. The first product of creative writing to see the light was a novelette with the title Sasavona by D.C. Marivate, which was published in 1938. This booklet won him the prize of $€ 10$ in a competition of the International Institute of African Languages and Cultures in 1936.

An essential feature of the first edition of Chatelain's dictionary is that the first section contained an exposition of the grammar of the language, while the second section comprised the dictionary itself. An unfortunate omission in this dictionary is that the tone of the Xitsonga words was not marked. Although the marking of tone cannot be a hundred percent accurate, it is essential to indicate this feature because Xitsonga is a tone language. Only the basic tone should be marked and in the introduction a brief note on Xitsonga tone assimilation should be included.

The next dictionary to be published was by Revd R. Cuénod, Tsonga/ English Dictionary, which appeared in 1967. As the name indicates, the entries are Xitsonga words followed by their English equivalents. There are no reversed entries in English with equivalents in Xitsonga. This is a much larger work than Chatelain's dictionary and has since been reprinted five times.

A good feature of this dictionary is the introduction in which the author gives a brief outline of the grammar of the Xitsonga language. The tone of the Xitsonga entries is also marked. Unfortunately, there are many instances where the copulative tone has been used and this does not reflect the tone of the word when it is in isolation. The author has also included an appendix of a selection of terms created by the Xitsonga Language Committee. This is a useful addition and forms the rudiments of a technical dictionary.

In 1983, K.B. Hartshorne published the Dictionary of Basic English, with an appendix containing the Xitsonga equivalents for all the English entries in the dictionary. This is a valuable dictionary which was compiled for pupils who studied English as a second or foreign language. 
Alongside these developments were the activities of the Education Department to develop the African languages to a higher level of expressiveness so that they can be used as media of instruction at school.

Language Committees and Language Boards were established to cater for the planned development. This resulted in terminology lists which were published and updated from time to time. The last of these for Xitsonga was the Tsonga Terminology and Orthography, published in 1980. In spite of some shortcomings, these terminology lists serve as useful reference sources for learners of the Xitsonga language.

Still in the pipeline are two Xitsonga dictionaries. Modern Xitsonga/English Dictionary compiled by E.J.M. Baumbach and D.I. Mathumba is currently at Pharos Dictionaries. The popular Xitsonga dictionary by Malungana, edited by D.I. Mathumba, is also to be published by Pharos Dictionaries.

A common denominator of these dictionaries is the fact that they are all bilingual dictionaries. Furthermore, they are all biased towards English, except the terminology list of the Department of Education, which is trilingual, Afrikaans occupying the middle column of the pages. This also points to a bias towards English, since no Afrikaans headwords feature. In spite of the strong inclination towards English, it is nevertheless not easy for an English-speaking person to use these dictionaries in learning the Xitsonga language, due to their one-sidedness. Only Chatelain's dictionary reverses the languages within one and the same dictionary.

\section{The needs}

From the foregoing exposition it is clear that the Xitsonga language still lacks many types of dictionaries that are necessary for its development and empowerment so that it may take its rightful place as an official language in South Africa.

Bilingual dictionaries such as those mentioned above, are mainly useful to English speakers who wish to learn Xitsonga, and vice versa. They do not contribute much to the development of the Xitsonga language.

Monolingual dictionaries, which Xitsonga lacks, have to fulfil this need. The expressive level of the language is greatly enhanced when concepts are explained in Xitsonga itself. Another area in which Xitsonga has lagged behind is that of bilingual dictionaries involving the Afrikaans language.

Since South Africa is a multilingual country and the people of the country opted for a policy of multilingualism, it is essential to have multilingual dictionaries. There are two such dictionaries but Xitsonga has not been included in them.

There is much talk today about the harmonisation of technical terms. This is a clear indication of the significance of a technical vocabulary. Xitsonga does not have any dictionaries in this area either. Closely related to this lack is the lack of dictionaries of literary and linguistic terms. If Xitsonga is to develop 
into an effective medium of instruction in the language itself, up to the highest level, dictionaries of linguistic and literary terms are indispensable. Such dictionaries will minimise or eliminate the use of different terms for the same concept, in the same country, in the same language, and will also enhance easy communication and exchange of information.

Lexicographers are not there to coin words. For this purpose terminographers are needed. When the terms have been developed, lexicographers systematise them into various types of dictionaries for different people to consult. To these dictionaries can be added thesauruses of synonyms, antonyms and so forth, as well as school and children's dictionaries. Spell checking programs for the computer are also needed.

Besides dictionaries themselves, there are other lexicographic needs experienced in Xitsonga. Xitsonga does not have specially trained people to be engaged in the production of Xitsonga dictionaries. At present this task is undertaken by personnel in tertiary institutions, especially universities. Understandably, these academics do not have enough time to devote to the compilation of dictionaries, with the result that there are considerable delays in the publication of these works.

To conclude, it can be said that although Xitsonga has dictionaries, they are all bilingual dictionaries which are heavily biased in favour of English. There is therefore a great need not only for new dictionaries, but also for expert lexicographers to produce them. 


\title{
Afrikaanse Spreekwoorde en Uitdrukkings: 'n makrostrukturele beskouing

\author{
Chrisna Beuke-Muir, Departement Germaanse en Romaanse Tale, \\ Universiteit van Namibië, Windhoek, Namibië
}

\begin{abstract}
Afrikaanse Spreekwoorde en Uitdrukkings: A Macrostructural Study. A restricted synchronic dictionary such as Afrikaanse Spreekwoorde en Uitdrukkings has an important role to play in modern lexicography where user-friendly reference sources facilitate communication. A considerable number of theoretical guidelines exist for the choice of lexicon items to be included in a dictionary, and this review article attempts to provide some pointers. The research also includes sociolinguistic implications which result from the compilation of the macrostructure of a particular dictionary. The focal points are firstly taboos to which lexicographers of Afrikaans dictionaries are subjected, and secondly establishing which expressions fall within the limits of idiomatic language usage. The treatment of idiom-like collocations particularly appears to be problematic. Another issue which will be considered briefly, is the morphological presentation of lemmas.
\end{abstract}

Keywords: PROVERBS, SET EXPRESSIONS, IDIOMS, COLLOCATIONS, KEYWORDS, TARGET USERS, POPULATION GROUPS, OTHER SOCIAL GROUPS, RACIST LANGUAGE, OFFENSIVE LANGUAGE, NEOLOGISMS, LEXICOGRAPHICAL LABELS, MORPHOLOGICAL PRESENTATION

Opsomming: 'n Beperkte sinchroniese woordeboek soos die Afrikaanse Spreekwoorde en Uitdrukkings het ' $n$ belangrike rol te vervul in die moderne leksikografie waar gebruikersvriendelike naslaanbronne kommunikasie vergemaklik. Heelwat teoretiese riglyne bestaan vir die keuse van taalvorme wat in die woordeboek ingesluit moet word, en hierdie resensieartikel probeer om 'n paar rigtingwysers te verskaf. Die ondersoek betrek ook sosiolinguistiese implikasies wat volg uit die samestelling van die makrostruktuur van 'n betrokke woordeboek. Die fokuspunte is eerstens die taboes waaraan leksikograwe van Afrikaanse woordeboeke onderwerp word, en tweedens die bepaling van watter uitdrukkings binne die grens van idiomatiese taalgebruik val. Veral die hantering van idioomagtige kollokasies blyk problematies te wees. 'n Ander kwessie wat kortliks aandag sal geniet, is die morfologiese aanbieding van trefwoorde.

Sleutelwoorde: SPREEKWOORDE, VASTE UITDRUKKINGS, IDIOME, KOLLOKASIES, TREFWOORDE, TEIKENGEBRUIKERS, BEVOLKINGSGROEPE, ANDER SOSIALE GROEPE, RASSISTIESE TAAL, KWETSENDE TAAL, NUUTSKEPPINGS, LEKSIKOGRAFIESE ETTKETTE, MORFOLOGIESE AANBIEDING 


\section{Inleiding: fokus en werkswyse}

Die Afrikaanse Spreekwoorde en Uitdrukkings (voortaan kortweg ASU) se makrostrukturele samestelling sal die fokuspunt in hierdie artikel wees. Dit sluit aspekte soos die volgende in: die afbakening van begrippe soos spreekwoorde, vaste uitdrukkings, e.s.m., die omvattendheid van 'n beperkte sinchroniese woordeboek soos die ASU en die opname van gemerkte taalvorme. Ook sal die morfologiese aanbieding van trefwoorde aandag geniet.

Die drie en twintigste uitgawe van die ASU kan o.a. beoordeel word op grond van die mate waarin die volgende belangrike tendense aan bod kom:

- die makrostrukturele samestelling n.a.v. die titel en die Toeligting,

- die opname van kollokasies,

- die beleid oor die opname van kwetsende taal,

- nuwe leksikale items,

- die ontsluiting van pragmatiese inligting m.b.v. etikette, en

- die morfologiese aanbieding van trefwoorde.

Die terme lemma en trefwoord moenie as sinonieme gebruik word nie (Gouws 1989: 36). Die onderskeid tussen hierdie twee terme is funksioneel omdat lemma volgens Gouws na daardie element verwys "wat in 'n woordeboek opgeneem word en volgens die betrokke woordeboek se ordeningsbeginsel ... geplaas word en van inligting voorsien word". Die term lemma verwys nie net na elemente wat woordstatus het nie, maar ook na elemente wat subleksikale of multileksikale eenhede is. Daarteenoor verwys trefwoord na 'n element wat woordstatus het. Vervolgens sal die term trefwoord gebruik word om na daardie element te verwys wat in die $A S U$ opgeneem word en alfabeties geplaas en van inligting voorsien word.

In die $A S U$ word die trefwoorde met 'n aanvangshoofletter geskryf. Hierdie praktyk wat nie in die $A S U$ se voorloper - voortaan kortweg ASU-1 gevolg is nie, bring verwarring mee omdat die onderskeid tussen eiename en ander woorde minder opvallend is. Slegs trefwoorde wat verband hou met eiename (bv. Simson in 'n Simson) behoort met ' $n$ hoofletter opgeneem te word. Sowel idiome, spreekwoorde, e.s.m. as die trefwoorde waaronder hulle opgeneem is, word in hierdie artikel vet gedruk.

\section{Die omvang van die makrostruktuur}

\subsection{Die keuse van die makrostruktuur n.a.v. die titel}

Beperkte sinchroniese woordeboeke se beperkheid is daarin geleë dat die leksikograaf 'n spesifieke doel met die bepaalde woordeboek het (Gouws 1989: 67). Uit die titel van die $A S U$ sou afgelei kon word dat die doel met hierdie woordeboek is om Afrikaanse spreekwoorde en uitdrukkings as 'n soort onderafde- 
ling van die leksikon van die Afrikaanse taal aan te bied. Indien hierdie onderafdeling van die Afrikaanse leksikon in 'n gespesialiseerde woordeboek opgeneem word, sal die gebruiker sekere verwagtings koester ten opsigte van die makrostruktuur. Die woordeboekgebruiker sou van so 'n gespesialiseerde woordeboek verwag dat dit vir die leksikograaf 'n besliste prioriteit sal wees om die leksikonitems van die spesifieke subtaal so volledig moontlik op te neem. In die Toeligting word die verwagting uitgespreek dat indien die gebruiker nie oor 'n omvattende woordeboek beskik nie, die $A S U$ geraadpleeg kan word. ' $n$ Omvattende Afrikaanse woordeboek is gerig op die Afrikaans in sy wydste omvang, en dus word die verwagting geskep dat nie net standaardtaal in die $A S U$ opgeneem sal word nie.

\subsection{Die begrippe spreekwoord, vaste uitdrukking, idioom en kollokasie}

Die afbakening van die begrippe spreekwoord, idioom, vaste uitdrukking en kollokasie is noodsaaklik omdat hulle ' $n$ rol speel in die keuse van die makrostruktuur van die $A S U$. finieer:

In die HAT word spreekwoord en idioom onderskeidelik soos volg gede-

spreekwoord Kort, kernagtige gesegde, gewoonlik welbekend en oud, waarin 'n algemene waarheid of wyse les uitgedruk is: Die môrestond het goud in die mond ...

idioom ... Vaste uitdrukking, segswyse wat eie is aan 'n bepaalde taal, bv. noustrop trek, in die broek sit.

Die WAT definieer idioom soos volg:

idioom ... Vaste uitdrukking, frase, gesegde van 'n taal, wat eienaardig is òf ten opsigte van grammatikale bou ò in sy betekenis wat gew. nie logies afgelei kan word van sy samestellende dele nie; eie manier van segging: Die segswyse wat eie is aan ' $n$ bepaalde taal, dikwels $i / d$ vorm van ' $n$ stukkie beeldspraak of vergelyking, word ' $n$ idioom genoem ...

Benson (1985: 68) se definisie van 'n idioom is die volgende: "an idiom is a relatively frozen expression whose meaning does not reflect the meaning of its component parts". Hy tref 'n onderskeid tussen idiome en spreekwoorde. Oor spreekwoorde laat Benson hom soos volg uit: "(they) convey folk wisdom or an alleged general truth" en gee dan as voorbeeld a bird in the hand is worth two in the bush. Hy voer die onderskeid verder op 'n sintaktiese vlak deur te sê dat spreekwoorde gewoonlik as volsinne voorkom, terwyl idiome normaalweg dele van sinne verteenwoordig.

Zgusta (1971: 152) se siening van spreekwoorde stem ooreen met dié van Benson. Hy (1971: 147) tref die volgende onderskeid tussen "real idiomatic expressions" en ander "multiword lexical units": terwyl meerwoordige leksi- 
kale eenhede direkte betekenisse het ("i.e. they simply designate a denotatum etc."), het ware idiomatiese uitdrukkings gewoonlik deurgaans figuurlike betekenisse. Hy stel dan ook die begrippe idiomatic expressions and set expressions gelyk aan mekaar.

Volgens Gouws (1989: 97) is ' $n$ kollokasie "'n kombinasie van verskillende leksikale items wat dikwels saam gebruik word", en die volgende voorbeelde word aangegee: 'n plegtige belofte, 'n beroep uitbring, in 'n stadium.

Hoewel Ponelis (1979: 352) nie die begrippe kollokasie of vaste uitdrukking eksplisiet definieer nie, kan uit die voorbeelde wat gegee word, sekere afleidings gemaak word. Onder die benaming vaste uitdrukkings word onder andere die volgende aangegee: spoorloos verdwyn, intiem ken, onwrikbaar glo, botweg weier, bloedig vererg, rot en kaal besteel, voor jou siel weet.

Uit die verskillende definisies hierbo kan die volgende afgelei word:

- Volgens die WAT en die HAT het idioom en vaste uitdrukking min of meer sinonieme betekenisse. Zgusta (1971: 147) verklaar dat "real idiomatic expressions" figuurlike betekenisse het. Die begrip spreekwoord (in teenstelling met idioom) blyk ' $n$ bykomende nuanse te hê deurdat dit meestal 'n geykte uitdrukking, en gewoonlik volsinne verteenwoordig. Kollokasies is uitgesluit by die begrippe spreekwoorde, idiome en vaste uitdrukkings deurdat hulle afsonderlike komponente se leksikale betekenis steeds gehandhaaf word (Gouws 1989: 227).

- Dit blyk dat die voorbeelde wat Ponelis (1979: 352) onder vaste uitdrukkings aangee (bv. spoorloos verdwyn, intiem ken, onwrikbaar glo e.s.m.) eerder kollokasies is volgens die betekenisse wat Gouws en Benson aan kollokasies toesê.

In hierdie artikel sal die term idiome vervolgens gebruik word as verwys word na idiome en vaste uitdrukkings soos wat die HAT, die WAT, Benson en Zgusta hierdie begrippe definieer. Die term sal ook spreekwoorde soos wat dit deur die $H A T$ en Benson verklaar word, insluit. Verder sal daar van die standpunt uitgegaan word dat 'n idioom wat die teikenmateriaal van die $A S U$ behoort te wees, oor die volgende eienskappe beskik: figuurlike betekenis (wat nie afleibaar is uit dié afsonderlike komponente nie) en grammatiese vastheid (wat betref sintaksis en morfologie).

\subsection{Kollokasies in die ASU}

Die belangrikste doel van ' $n$ beperkte idioomwoordeboek is om die totale betekenis van die komponente van die idioom weer te gee (Zgusta 1971: 209). Dit laat die vraag ontstaan of kollokasies tuishoort in die ASU as beperkte sinchroniese woordeboek waarin idiome en spreekwoorde verklaar word (vervolgens 
genoem idioomwoordeboek), aangesien kollokasies op 'n kontinuum vanaf heel deursigtig tot feitlik idiomaties aangedui kan word (Carstens 1992: 1).

Volgens Benson (1985: 62) is kollokasies nie idiome nie, aangesien hul betekenisse ongeveer afleibaar is van die betekenisse van hul komponente. Hierdie beskouing blyk te simplisties te wees, en hy laat hom ook nie uit oor die belangrike kwessie dat 'n kollokasie soms 'n idiomatiese karakter kan hê nie.

Volgens Carstens (1992: 2) lê die verskil tussen kollokasies en idiome hoofsaaklik op semantiese vlak. Ter illustrasie gebruik sy (1992: 4) o.a. die kollokasies vuil grappe en flou verskonings, en is van mening dat as een van die konstituente (vuil in eg. en flou in lg.) figuurlik geïnterpreteer kan word, sodanige kollokasies 'n "grenskategorie" vorm tussen kollokasies en idiome. Sy beskou hierdie tipe kollokasies as nieprototipiese idiome binne die kognitiewe benadering. In die $A S U$ is bogenoem de voorbeelde nie opgeneem nie, maar tereg word kollokasies soos 'n groot bek hê (grootpraat; windmakerig wees) en gebroke oë (sterwende oë) opgeneem.

Carstens (1992: 4) onderskei 'n verdere kategorie kollokasies waarin die werkwoorde 'n verswakte, gegrammatikaliseerde betekenis het (bv. ' $n$ besluit neem, 'n hoes gee, beswaar maak). Sy (1992: 5) is van mening dat hierdie tipe konstituente vir hul betekenisse hoofsaaklik afhanklik is van die betekenis van hul medekonstituente. Sodanige kollokasies waarin die werkwoord 'n verswakte, gegrammatikaliseerde betekenis het soos 'n kans gee, jou belofte hou, illusies $h \hat{e}$ en die voorneme $h \hat{e}$ wat almal in die $A S U$ opgeneem is, vertoon verder feitlik geen idioomkarakter nie, en hul opname sou bevraagteken kon word. 'n Kollokasie soos jou debuut maak sou kon tuishoort in hierdie kategorie. Maar die opname is in hierdie geval tog geregverdig: die letterlike betekenis van debuut wat volgens die $H A T$ as "eerste openbare optrede van 'n skrywer, kunstenaar, ens." aangegee word, het betekenisverruiming ondergaan sodat ' $n$ idiomatiese betekenis - volgens die $A S U$ "jou eerste verskyning maak; vir die eerste keer deelneem" - ontwikkel het. Dieselfde argument kan vir inskrywings soos amok maak, en 'n hoofrol speel aangevoer word. Sodanige kollokasies het wel 'n idioomkarakter, en is tereg in die ASU opgeneem.

\section{Kwetsende taalgebruik}

\subsection{Die Buro van die WAT se beleid t.o.v. kwetsende taalgebruik}

In die Toeligting tot die ASU word gemeld dat kwetsende segswyses met betrekking tot bevolkingsgroepe weggelaat is. Die WAT verklaar die term bevolking as die aantal persone wat op ' $n$ gegewe tydstip 'n bepaalde gebied bewoon. Hiervolgens sal die inwoners van Duitsland, Nederland, Suid-Afrika, e.s.m. as afsonderlike bevolkingsgroepe beskou kan word. By verdere navraag onder kollegas en medemoedertaalsprekers van Afrikaans, word bevolkings- 
groep ook geinterpreteer as "mense behorende tot dieselfde etniese groep". Laasgenoemde interpretasie sal in hierdie artikel geld.

In die beleid van die Buro van die WAT (voortaan kortweg Buro) oor die opname van kwetsende taalgebruik word gemeld dat die onophefbaarheid van eienskappe wat toegeken word aan sekere kwetsende taalvorme 'n essensiële kenmerk is wat bv. rassismes van ander vorme van kwetsende taalgebruik soos vloekwoorde onderskei. Van die drie kategorieë kwetsende taalvorme wat die Buro identifiseer (Harteveld en Van Niekerk 1995: 238-243), is dit veral twee wat vir hierdie artikel van belang is, nl. (i) rassismes bv. aia, Boesman, kaffer, Kleurling, hotnot, Kaaskop, witvel, en (ii) seksismes en sensitiewe leksikale items wat gestigmatiseerde seksuele verskynsels, praktyke en voorkeure aandui bv. oujongnooi, snol, kween, moffie.

Wat rassismes betref, maak die Buro ' $n$ onderskeid tussen volledig rassistiese en gedeeltelik rassistiese leksikale items. Gedeeltelik rassistiese taalvorme word meer volledig bewerk as volledig rassistiese taalvorme. Volgens die Buro se beleid word rassistiese uitdrukkings gelemmatiseer, geëtiketteer en uiters sensitief en neutraal bewerk (Harteveld en Van Niekerk 1995: 239, 240). Ook seksistiese taal word volledig bewerk, onderworpe aan 'n reeks voorwaardes (Harteveld en Van Niekerk 1995: 241-243).

Dit is dus verblydend dat dit nie die beleid van die Buro is om weg te skram van rassistiese en seksistiese taalvorme nie, hoewel dit met die nodige sensitiwiteit gehanteer word. Uiters noodsaaklik is die etikettering van sodanige taalvorme, met dié verstandhouding dat die etikette volledig in die Toeligting verklaar word, en die woordeboekgebruiker dus onomwonde bewus gemaak word van die negatiewe konnotasies van die betrokke taalvorme.

Daar bestaan uiteenlopende menings oor die hantering van rassismes en seksismes in woordeboeke. Die resensent glo persoonlik dat rassistiese en seksistiese taal nie uit ' $n$ woordeboek geweer mag word nie, aangesien woordeboeke alle manifestasies van taal in die samelewing behoort te weerspieël. Die gees van versoening wat toeneem onder sprekers van Afrikaans in SuiderAfrika skep 'n klimaat waarin die belewing van rassismes (en seksismes) minder fel is (Harteveld en Van Niekerk 1995: 238).

Dit blyk dat hierdie standpunt ook tot op regsvlak aangevoel word. Hauptfleisch $(1993: 114,115)$ maak melding van hofsake waarin uitgewers hulself moes verdedig oor rassistiese taal in woordeboeke. In die meeste gevalle het die uitgewers die saak gewen. Hauptfleisch glo dat die redakteurs van woordeboeke hulle nie onnodig moet laat terroriseer deur emosionele opwellinge van groepe nie, en dat weldeurdagte woordeboeke waarin omstrede taalvorme gehanteer word, die deurslag moet gee.

\subsection{Die hantering van kwetsende taal in die $A S U$}

Taalvorme soos ' $n$ Boesmantjie doodslaan, los hotnot, bleekvel, en iemand is skeef is nie opgeneem nie, terwyl Kaaskop, Woltoon en Vaalpens wel inge- 
sluit is. Hieruit sou afgelei kon word dat daar nie konsekwent te werk gegaan is met die opname van kwetsende taal in die ASU nie. Sosiologies kan dit wyer reperkussies hê deurdat dit 'n sekere stigma van oorsensitiwiteit aan die betrokke groep waarna die taalvorm verwys, laat kleef.

\subsection{Die teikengebruiker}

Die vraag ontstaan: in hoeverre mag die leksikograaf deur die sosiale samestelling van die samelewing beinvloed word in die bepaling van die makrostruktuur? Hauptfleisch (1993: 119) gee die volgende riglyn: hy gaan van die veronderstelling uit dat kwetsende taal veral uit skoolwoordeboeke geweer behoort te word.

Dit sou egter die nadeel inhou dat dit reeds op ' $n$ vroeë leeftyd by die leerling die wanbegrip kan laat posvat dat woordeboeke net "netjiese" taal akkommodeer (en dat taalvorme wat nie in die woordeboek opgeneem word nie, as 't ware nie gereken word as behorende tot die taal se woordeskat nie).

In die Toeligting van die $A S U$ word daar nie eksplisiet gemeld wie die teikengroep is nie. Die enigste leidraad wat hieroor onder die subopskrif "Hoe volledig is die versameling?" gegee word, is dat die behoeftes van die "gewone leser" as oorweging gebruik is vir die opname van sekere taalvorme. Dit versterk die idee dat die $A S U$ nie bedoel is om as 'n skoolwoordeboek te funksioneer nie. Dus sou die weglating van kwetsende taal nie op grond van hierdie argument geregverdig kon word nie.

Volgens Householder en Saporta (1962: 279) is een van die kriteria waarvolgens die teikengroep vir 'n woordeboek bepaal word, die vlak van taalkennis. Die teikengroep vir die $A S U$ is sowel moedertaalsprekers as niemoedertaalsprekers, en daarvan getuig die baie nuttige tweetalige indeks wat die woordeboek vir Engelssprekendes gebruikersvriendelik maak.

\section{Vernuwing}

In die Toeligting word gemeld dat die $A S U$ hersien is, en meer omvattend is as sy voorganger. Dit blyk dat ' $n$ groot aantal taalvorme wat in die ASU-1 verskyn het, in die nuutste weergawe weggelaat is terwyl slegs enkeles nuut bygekom het. Onder die letter A is 204 idiome (bv. onder die trefwoorde aalwynpil, aangeskole, e.s.m.) weggelaat terwyl twee onder die trefwoorde agterhoede en as (die agterhoede dek en iets is 'n groot "as") bygekom het. Verder is weggedoen met verskeie uitgediende betekenisonderskeidings wat in die ASU-1 vermeld is onder die lemmas wat ook in die $A S U$ verskyn. Daar is dus 'n daadwerklike poging aangewend om ou hout uit te sny.

In teenstelling met die wegdoen van verouderde idiome, is daar nie veel nuwes toegevoeg nie. Dit dui nie noodwendig op ' $n$ tekortkoming nie aangesien nuutskeppings (en dan spesifiek nog idiomatiese nuutskeppings) nie som- 
mer oornag ontstaan nie. Tog ontbreek dit nie aan nuutskeppings nie, veral ten opsigte van relatief nuwe werklikhede soos die televisie (kassie, vierkantige oë), die rekenaar (blikbrein) en veral die nuwe politieke Suid-Afrikaanse bestel (reënboognasie, soustrein).

\section{Etikette}

\subsection{Die Toeligting}

Leksikografiese etikette word gebruik om pragmatiese inligting in woordeboeke te ontsluit, en meer spesifiek gee dit inligting oor die beperking in die gebruik van die lemma (Gouws 1989: 4). Etiketwaardes behoort in die Toeligting verklaar te word. Die enigste etikette wat in die $A S U$ voorkom, is verouderd en plat, maar slegs verouderd word verklaar as verwysend na items wat "dikwels nog in ouer geskrifte opduik". Die etiket plat is egter nie verklaar nie. Veral ten opsigte van stilistiese etikette is 'n uitleg van etiketwaardes onontbeerlik.

\section{$5.2 \quad$ Nuutskeppings}

'n Nuutskepping sou in die $A S U$ as sodanig gemerk kon word met dien verstande dat dit verkry word uit 'n gerekenariseerde databasis waarin die data gekoppel word aan 'n vasgestelde tydperk. In die Toeligting sou die tydperk deur middel van ' $n$ jaartal aangedui kon word. So sou byvoorbeeld taalvorme wat sedert die televisie-era ontstaan het, met nuut geëtiketteer kon word, en in die Toeligting sou nuutskepping bv. verklaar kon word as "taalvorme wat na 1970 ontstaan het".

\subsection{Kwetsende taalgebruik}

Kwessies rondom die opname van kwetsende taal in die $A S U$ is reeds breedvoerig in afdeling 3 van hierdie artikel bespreek. Kwetsende taalvorme behoort opgeneem te word met die nodige etikette om hul beperking in gebruik aan te dui. In die $A S U$ sou meer as een etiket (bv. rassisties en seksisties) gebruik kon word om die betrokke kwetsende taalvorme te merk. Selfs verskillende grade van rassisties sou deur middel van etikette aangedui kon word. So sou die etiket rassisties volledig rassistiese taalgebruik (volgens die Buro se beleid) kon uitwys, terwyl gedeeltelik rassistiese taalvorme geëtiketteer kon word met die etiket gedeeltelik rassisties. Die etiketwaardes moet dan duidelik in die Toeligting verklaar word. 


\section{Trefwoorde}

\subsection{Morfologiese vorm}

Die $A S U$ het verbeter op sy voorganger deurdat 'n snaakse entjie mens onder die trefwoord entjie opgeneem is, en nie meer onder ent nie. So ook is loop voor die pad vol duwweltjies is opgeneem onder duwweltjies en nie onder duwwels soos in die $A S U-1$ nie. Hierdie praktyk is egter nie konsekwent toegepas nie, want flikkers gooi, fonteintjie, ek sal nooit weer van jou drink nie en jou kaiings sal braai is onder flikker, fontein en kaiing onderskeidelik geplaas. Aldrie hierdie gevalle is in die ASU-1 korrek onder flikkers, fonteintjie en kaiings gehanteer. Die gevalle kapriolle mak en kluitjies bak is weer, soos in die ASU-1, onder kapriol en kluitjie onderskeidelik behou.

Indien ' $n$ trefwoord net in die verlede tyd in die idioom funksioneer, behoort die trefwoord in sy verledetydsvorm te verskyn. So moes iemand geweeg en te lig bevind eerder onder geweeg verskyn het en nie onder weeg nie.

Dieselfde argument geld as 'n verlede deelwoord in die idioom voorkom en as trefwoord funksioneer. So moes op jouself aangewys wees eerder onder aangewys as trefwoord verskyn het, en nie onder aanwys nie, en iets op sy elfen-dertigste doen eerder onder elf-en-dertigste geplaas gewees het as onder elf-en-dertig soos dit in die ASU die geval is.

Indien idiome twee verskillende gebruikswyses het deurdat hulle in die onverboë en in die verboë vorm as verskillende idiome gebruik word (bv. eend in dis maklik gesê, maar die eend lê die eier, en eendjie in 'n lelike eendjie) sou dit die woordeboek gebruikersvriendelik maak om beide die trefwoorde op te neem.

Indien 'n skeibare werkwoord in 'n idioom soos hef aan lê nog voor slegs in sy geskeide vorm voorkom, behoort die idioom onder hef opgeneem te word, en nie onder aanhef soos in die $A S U$ nie.

In die $A S U$ word nie eksplisiet voorbeeldmateriaal aangegee nie. Dat die idioom in die meeste gevalle ook 'n gebruikspatroon aangee, het tot gevolg dat voorbeeldmateriaal nie so noodsaaklik is in 'n idioomwoordeboek nie. Voorbeeldmateriaal sou egter nuttig wees om die verskillende gebruike van die trefwoord uit te wys indien die trefwoord in sowel sy onverboë as verboë vorm in dieselfde idioom gebruik kan word.

In algemene woordeboeke verskyn lemmas gewoonlik in hul onverboë vorme. By ' $n$ idioomwoordeboek sou 'n ander kriterium kon geld. As 'n trefwoord in die idioom slegs in die verboë vorm voorkom en nooit in die onverboë nie, behoort die trefwoord in die betrokke verboë vorm opgeneem te word. Watter redaksionele beleid ook al geld, behoort duidelik in die Toeligting uitgespel te word. 


\subsection{Homonimie}

Verblydend is dat aan die hantering van homonieme aandag gegee is. Die soms foutiewe hantering daarvan in die $A S U-1$ (haai $^{1}$ en haai ${ }^{2}$, en kaatjie ${ }^{1}$ en kaatjie ${ }^{2}$ is byvoorbeeld as homonieme aangegee) is in die nuutste uitgawe reggestel. Problematies is egter die feit dat $\mathbf{k o l}^{\mathbf{2}}$ en $\mathbf{~ k o l}^{2}$ in die $A S U$ as homonieme opgeneem is. Homonimie het te make met "the relationship between words whose forms are the same but whose meanings are different and cannot be connected" (Matthews 1997: 164). Volgens hierdie definisie is kol' ${ }^{1}$ en kol $^{2}$ eerder poliseme, "with two or more related senses" (Matthews 1997: 285). Poliseme behoort onder een trefwoord in woordeboeke geakkommodeer te word (Gouws 1989: 123).

\section{Etimologie}

Vir die woordeboekgebruiker sou dit interessant wees om meer te wete te kom oor die oorsprong van idiome soos iemand van babo na bibo stuur en na Canossa gaan. Etimologiese gegewens is nie net interessant nie, maar in die geval van idiome waarvan die oorsprong nie afleibaar is van die betekenisse van die afsonderlike komponente nie, is die aangee daarvan waarskynlik noodsaaklik.

\section{Gevolgtrekking}

Besware wat in hierdie artikel teen die $A S U$ geopper word, is:

- dat kwetsende taalvorme inkonsekwent gehanteer word: dit het nie alleen leksikografiese nie, maar ook sosiolinguistiese implikasies;

- dat te min nuwe idiome opgeneem is;

- dat etimologiese gegewens nie vermeld word nie;

- dat etikette nie genoegsaam gebruik word nie; en

- dat die Toeligting nie voldoende inligting gee oor beleidsake, etikette, e.s.m. nie.

Ten spyte van die enkele punte van kritiek wat in hierdie artikel uitgespreek is, is die ASU 'n naslaanbron van onskatbare waarde vir die woordeboekgebruiker op soek na ' $n$ idioom of sy betekenis. Soos Van Niekerk (1998: 34) opmerk, sal dit veral vir vertalers en tolke 'n kosbare naslaanbron wees vanweë die Engelse indeks. 


\section{Verwysings}

\section{Woordeboeke}

Matthews, P.H. 1997. Oxford Concise Dictionary of Linguistics. New York: Oxford University Press.

Odendal, F.F. et al. (Reds.). 1994. Verklarende Handwoordeboek van die Afrikaanse Taal. Midrand: Perskor.

Prinsloo, A.F. 1997. Afrikaanse Spreekwoorde en Uitdrukkings. Pretoria: J.L. van Schaik.

Schoonees, P.C. et al. (Reds.). 1970-1995. Woordeboek van die Afrikaanse Taal. Pretoria: Staatsdrukker.

\section{Ander bronne}

Benson, Morton. 1985. Collocations and Idioms. Ilson, Robert (Red.). 1985: 61-68.

Carstens, Adelia. 1992: Kollokasies: vrye verbindings of lekseme? Suid-Afrikaanse Tydskrif vir Taalkunde 10(1): 1-11.

Gouws, R.H. 1989. Leksikografie. Pretoria: Academica.

Harteveld, P. en A. van Niekerk. 1995. Beleid vir die hantering van beledigende en sensitiewe leksikale items in die Woordeboek van die Afrikaanse Taal. Lexikos 5B: 232-248.

Hauptfleisch, D.C. 1993. Racist Language in Society and in Dictionaries: A Pragmatic Perspective. Lexikos 3: 83-139.

Householder, F.W. en S. Saporta (Reds.). Problems in Lexicography. Bloomington: Indiana University.

Ilson, Robert (Red.). 1985. Dictionaries, Lexicography and Language Leaming. Oxford: Pergamon Press.

Ponelis, F.A. 1979. Afrikaanse Sintaksis. Pretoria: Van Schaik.

Van Niekerk. A. 1998. Afrikaanse spreekwoorde en uitdrukkings. Suid-Afrikaanse Tydskrif vir Taalkunde 16(1): 34 .

Zgusta, L. 1971. Manual of Lexicography. Den Haag: Mouton. 


\title{
Situating A Dictionary of South Afri- can English on Historical Principles within a More Comprehensive Lexicographic Process
}

Rufus H. Gouws, Department of Afrikaans and Dutch, University of Stellenbosch, Stellenbosch, Republic of South Africa

\begin{abstract}
South African English can be regarded as a fully-fledged variety of English which qualifies for comprehensive lexicographic treatment. This paper focuses on the presentation and treatment of South African English in A Dictionary of South African English on Historical Principles. The structure of this dictionary as a carrier of texts and the way in which the editors adhere to current metalexicographic guidelines are discussed. This paper also situates the dictionary and its contribution within the broader South African lexicographic endeavour. Reference is made to other South African dictionaries in order to identify the position of this dictionary within the South African dictionary family.
\end{abstract}

Keywords: BACK MATTER, CARRIER OF TEXTS, CENTRAL LIST, FRAME STRUCTURE, FRONT MATTER, HISTORICAL DICTIONARY, LEXICOGRAPHY, SOUTH AFRICAN ENGLISH, STRUCTURAL COMPONENTS

Opsomming: Die situering van A Dictionary of South African English on Historical Principles binne 'n omvattender leksikografiese proses. Suid-Afrikaanse Engels kan beskou word as ' $n$ volwaardige variëteit van Engels wat kwalifiseer vir ' $n$ uitvoerige leksikografiese behandeling. Hierdie artikel fokus op die aanbieding en bewerking van Suid-Afrikaanse Engels in A Dictionary of South African English on Historical Principles. Die struktuur van hierdie woordeboek as ' $n$ draer van tekssoorte en die manier waarop die redaksie bestaande metaleksikografiese riglyne nagevolg het, word bespreek. Dié artikel plaas die woordeboek asook sy bydrae binne die breër Suid-Afrikaanse leksikografiese bestel. Daar word na ander Suid-Afrikaanse woordeboeke verwys ten einde die posisie van hierdie woordeboek binne die Suid-Afrikaanse woordeboekfamilie te bepaal.

Sleutelwoorde: AGTERWERK, HISTORIESE WOORDEBOEK, LEKSIKOGRAFIE, RAAMSTRUKTUUR, SENTRALE TEKS, STRUKTUURKOMPONENTE, SUID-AFRIKAANSE ENGELS, TEKSSOORTDRAER, VOORWERK

\section{South African English: a general background}

The history of lexicographic reference works in South Africa emphasises the dominating role of Afrikaans descriptive and translation dictionaries. How- 
ever, the position of English, and more specifically South African English, in the development of South African dictionaries may never be underestimated. Changuion (1844) and Mansvelt (1884) compiled two of the most important forerunners in the domain of descriptive dictionaries focusing on Afrikaans. Although both these dictionaries played a key role in establishing Afrikaans lexicography, the respective lexicographers had opposing objectives. Changuion's dictionary was an attempt to impede the development of Afrikaans and to maintain the continued use of Dutch in the Cape. Contrary to this approach Mansvelt focused on the uniqueness of the developing Afrikaans lexicon by including those words and expressions not known in standard Dutch. Although the macrostructure of his dictionary has to be seen as one of the first lexicographic accounts of Afrikaans, it included many items commonly known and used in the South African English of that time. In this regard the Mansvelt dictionary should also be seen as an asset to the development of South African lexicography in general as well as the lexicography of South African English. The lemma selection did not only represent the lexicon of Afrikaans but also focused on numerous lexical items coined in South Africa and used in different South African languages. Many of these lexical items can rightly be classified as being South African.

In 1902/1904, shortly after the Anglo-Boer War (1899-1902), the bilingual Patriot Woordeboek/Patriot Dictionary was published. The primary objective of this dictionary was not to be a linguistic instrument but rather to fulfil a sociopolitical function. In the preface the anonymous editor (S.J. du Toit) stated it quite emphatically that the principal aim of this dictionary was to promote cooperation between the English and the Dutch in South Africa, for which purpose it was indispensable that they should mutually know each other's language in so far that they could understand each other. The first part of this dictionary (Afrikaans-English) was published in 1902 and the second part (English-"Cape Dutch") in 1904. The macrostructure of the first part consisted of approximately 16500 lemmata which included about 1100 words which were, according to the editor, pure Cape Dutch, in so far that they were not found in Dutch dictionaries or had a different meaning in Dutch. These forms were presented in italics to differentiate them from the other lemmata.

From a linguistic point of view it is noteworthy that the treatment of these pure Cape Dutch items does not reflect the dynamics of language contact and the consequential and frequent occurrence of borrowings in South African English. One of the objectives of a translation dictionary should be to achieve communicative equivalence. This can only be done if the co-ordination of source and target language items is dominated by a functional approach. Rather than to list translation equivalents with the same meaning as the lemmata, the lexicographer should attempt to present target language items representing the same style and register of the source language items. In general the lexicographic procedures applied in the Patriot Woordeboek/Patriot Dictionary creates a low density of information because the treatment is usually restricted to the pres- 
entation of translation equivalents. In the Afrikaans-English section the existence of a relation of zero equivalence, due to the lack of an established English equivalent, leads to the inclusion of surrogate equivalents. However, these surrogate equivalents do not reflect the real linguistic situation regarding the lexicon of South African English. Instead of co-ordinating unique South African English equivalents with the Afrikaans lemmata, the lexicographer opted for the use of brief meaning descriptions. This has resulted in Patriot Woordeboek/Patriot Dictionary being a translation dictionary with the focus primarily on the lexicon of Afrikaans and not on the lexicon of South African English. Many of the pure Cape Dutch items included as lemmata in the Patriot Woordeboek/Patriot Dictionary could just as well have been co-ordinated with the same item as a target language form because of the occurrence of these forms in both languages. This would have established Patriot Woordeboek/Patriot Dictionary as an innovative instrument in the recording of South African English.

In spite of the fact that Patriot Woordeboek/Patriot Dictionary did not give a true account of the development of English in South Africa, it has to be regarded as an important contribution to the development of South African lexicography because of the co-ordination of languages which were destined to become two official languages of South Africa, as well as the fact that this was one of the first efforts to establish lexicographic links between these two languages.

A second contribution to and probably the most important breakthrough in the early development of the lexicography of South African English (henceforth abbreviated as SAE) was the publication in 1913 of Charles Pettman's Africanderisms. In this "glossary of South African colloquial words and phrases", the compiler reflects on the lexical expansion in South Africa. Although he does not refer to South African English but rather to South African, it is quite apparent that he is dealing with the lexicon of SAE. In the preface of this dictionary Pettman says: "When, by some strange oversight, the great 'Oxford Dictionary' not only omits to notice such recognised English words as African and Africanism ..., to say nothing of such well-known South African words as Africander, Africanderism, and Africanderdom, there does appear to be an excuse, if not a reason, for the publication of a Glossary of South African Words and Phrases." The macrostructure of this dictionary deals extensively with typical "South African" words, and the treatment usually includes an explanation of the meaning of the lemma. It is interesting to note how many of these "South African" lexical items also occur as Afrikaans lemmata in the dictionary of Mansvelt and in the Patriot Woordeboek/Patriot Dictionary.

From an historical perspective the importance of Pettman's work is the emphasis it places on SAE as a new and developing variety of English. This dictionary should not only be regarded as a direct forerunner of Penny Silva's A Dictionary of South African English on Historical Principles, but it also has to be seen as one of the most important cornerstones of the lexicographic representation of South African English and the relevant lexicographic process. This is 
acknowledged in the front matter of A Dictionary of South African English on Historical Principles, where the editors express with gratitude "the considerable debt owed to this dictionary's predecessors, particularly Africanderisms".

\section{A Dictionary of South African English on Historical Principles and the Dictionary Unit for South African English}

When attempting to situate $A$ Dictionary of South African English on Historical Principles (henceforth abbreviated as DSAE) within a more comprehensive South African lexicographic process one also has to focus on the institution responsible for this publication. This is necessary to evaluate the status of DSAE within the broader South African lexicographic family. In this regard DSAE offers enough assistance. The front matter of this dictionary contains a variety of texts, among others a short report on the Dictionary Unit of South African English. What was later to be established as the Dictionary Unit of South African English was started in 1968 as a pilot project on South African English. In an early report of the project (Towards a Dictionary of South African English, September 1971), Prof. William Branford, who was to be the first editor-in-chief, described the aim of the project as being "to provide an historical record of the South African element in the English vocabulary from its first appearances in the language down to the present day". In a later text (1976) Branford described the aims of the Unit as being first the production of a dictionary containing South Africanisms in English (once again the Pettman influence can be detected). This was to be an independent project. The second aim was the publication of a dictionary of South African English on historical principles, which was to be a much more comprehensive project.

Both these aims have been realised. The first aim resulted in the publication A Dictionary of South African English (1978). The fourth edition of this dictionary was published in 1991. The front matter of DSAE contains the following comment on this dictionary: "This general readers' dictionary, which, in addition to the standard vocabulary, includes colourful colloquial and slang expressions, and often quirky or humorous illustrative citations, is, in the compiler's own words in the preface, 'intended to be useful; but ... intended also to give pleasure and amusement'." Although this dictionary focuses on South African English, it also compares the use and meaning of words in SAE with other varieties of English. Extremely helpful in this dictionary is the inclusion of notes on the usage of SAE. The first aim was not only realised by the publication of this dictionary, but also by the South African Pocket Oxford Dictionary (1987).

A Dictionary of South African English on Historical Principles represents the realisation of the second but main aim of the Dictionary Unit for South African English. The Dictionary Unit was formally established in 1991. In the front matter of DSAE the initial task of the Unit is described as: "the continuous and comprehensive collecting, arranging and storing in a lexicographically workable form of the vocabulary of the English language as used in Southern Africa 
and the editing and publication of the collected materials in the form of a Dictionary of South African English on Historical Principles, as well as periodical revision and updating of the text thereof and other research and publications associated therewith". The publication of DSAE is the fulfilment of the first phase of this task.

\section{The need for a dictionary of South African English}

Since 1994 South Africa has eleven official languages. Although the constitution guarantees the official status of all these languages, practical demands play an important role in determining the choice of languages in communication situations. In spite of the fact that the number of native speakers of English in South Africa is smaller than that of e.g. Zulu, Xhosa and Afrikaans as well as some of the other indigenous languages, English has a dominating position as language of documentation and as a general lingua franca. For too long South Africans had to rely exclusively on English dictionaries from British and American publishers to solve problems they experience in South African English (cf. Gouws 1995). The traditional link between South African and British English has been advantageous for British dictionaries and this has resulted in South Africa being a good dictionary market for British publishers. The increasing influence of American English, mainly due to television and film productions, has resulted in a more productive use of American dictionaries. As part of their endeavour to achieve an international character some of these dictionaries have included a limited number of lemmata to represent SAE as one of the varieties of English. These attempts also indicate that SAE has made a certain contribution to international English. Due to the growing need for a well-documented account of SAE the publication of a dictionary like the DSAE as part of the South African lexicographic process has been long overdue.

Within the South African language situation SAE has a central position. $\mathrm{SAE}$ has a standard form but also numerous varieties. Language dynamics and the daily contact with the other official South African languages have a constant influence on an ever-changing SAE. No dictionary not primarily aimed at $\mathrm{SAE}$, can give a valid account of these changes and of all the registers of this variety of English. Local lexicographers who are able to make a valid and representative selection and a sound lexicographic treatment of items from the lexicon of SAE can achieve this ideal. DSAE does this in an exemplary way. The objectives of the editors to achieve this are signalled by the following remark in the preface: "the editors have made a conscious attempt to give voice not only to the documented utterances of powerful men, but also to the daily speech of ordinary people". Another remark in the preface which gives a good perspective on the function and the assignment of this dictionary is a reference to the fact that SAE is not only the property of South Africa's relatively small number of English-speakers (about 10\% of the population), but it is also the property of those people, a much greater number, who use English as a second or third language. 


\section{The structure of the DSAE}

\subsection{Taking cognisance of advances in metalexicography}

Linguists and lexicographers hold different views regarding the status of lexicography. Whether it is a science, a craft, a special technique or an art is not clear. According to Wiegand (1989: 248) lexicography is not a science but a scientific practice. Where scientific activities are aimed at producing theories, this is not true of lexicographic activities. The one common feature of all lexicographic activities is their aim to produce dictionaries that can be used as practical instruments. Lexicography is a practice aimed at the production of dictionaries. This forms the basis of another practice, i.e. the cultural practice of dictionary use. Although linguistic theories influence the lexicographic practice, these theories are not primarily aimed at lexicography. For decades lexicographers had to analyse and interpret existing linguistic theories in order to find something applicable to lexicography. This situation has emphasised the need for a general theory of lexicography that can assist lexicographers with the necessary theoretical input. One of the exciting developments of the last two decades has been the establishment of metalexicography as a fully-fledged discipline, and the inclusion of a general theory of lexicography as one of the important components of metalexicography. This has had numerous implications for the lexicographic practice.

Innovative and profound developments in metalexicography have compelled lexicographers not only to take cognisance of the relevant theoretical issues but also of the practical implications thereof. Today there is no reason why any practising lexicographer should fail to comply with the criteria laid down by a general theory of lexicography for the specific dictionary being compiled. In this regard lexicographers should not only adhere to the demands directed at the nature, extent and presentation of information categories in the microstructure, but also to the selection of a representative macrostructure. This is important, but the user-perspective, so prevalent in modern-day metalexicography, which compels the lexicographer to identify the target user of the dictionary and to compile the dictionary with the needs and reference skills of that target user in mind, has to dominate lexicographic procedures. Likewise lexicographers have to take cognisance of the emphasis on the structure of dictionaries and the different structural components identified in the textual approach to dictionaries.

\subsection{Structural components}

\subsubsection{The front matter}

Within the metalexicography dictionaries are regarded as carriers of texts. Provision is made for a three-way structural division in a dictionary, i.e. the front 
matter, the back matter and the central list. The back matter is an optional component where texts dealing with issues like units of measure, country names, capitals, encyclopaedic information, etc. can be accommodated. The front matter contains a variety of optional texts like the title page, the table of contents, etc. There is one obligatory text to be included in the front matter, i.e. the user's guide. The central list contains the dictionary proper. It is a functional component of the dictionary and is constituted by a collection of subtexts: the articles. Each article contains a lemma, the element from the lexicon to be treated which functions as the guiding element of the article, and a lexicographic treatment of the lemma (cf. Hausmann and Wiegand 1989: 330-333).

As an obligatory text the user's guide explains the system adhered to in the dictionary. Any good dictionary is characterised by the consistent application of a well-developed system, and this system has to be explained in the front matter. One of the components of metalexicography, viz. the organisation theory, makes provision for various aspects of the planning of dictionary projects. The planning of the compilation of a dictionary starts with the planning of the system to be utilised in the specific dictionary as well as the data distribution structure which determines the position and presentation of the different data categories (cf. Bergenholtz, Tarp and Wiegand 1999). Before putting one word onto paper in the compilation process, the lexicographer has to be well aware of the precise structure each article should display so that the system can be applied with meticulous care from aardvark to zebra.

Only a quick glance at DSAE is needed to convince one that the editors have made an effort to compile a well-structured dictionary, displaying a typical frame structure (cf. Kammerer and Wiegand 1998), which assists the user not only by means of the central list but also by including a selection of texts in the front and back matter. The front matter of a dictionary is not as a whole a functional part because it contains an arbitrary set of functional text parts. The central list of DSAE is preceded by a front matter which consists of a variety of functional text parts. These front matter texts include the title page, a text containing various acknowledgements, a preface, table of contents, a brief history of the Dictionary Unit for South African English, a text with the title "English in South Africa", and two maps (South Africa 1910-March 1994 and South Africa April 1994-). These texts are followed by further texts focusing on linguistic and lexicographic information and conventions, i.e. a discussion of the pronunciation of South African English, a key to the pronunciation given as part of the treatment in DSAE and the styling conventions as well as a list of the abbreviations used in this dictionary.

The functional value of the front matter texts in DSAE may never be underestimated. By mearss of the information displayed in several unintegrated outer texts (cf. Bergenholtz, Tarp and Wiegand 1999), the user is orientated with regard to the institution responsible for the compilation of this dictionary as well as the target language of the dictionary, viz. South African English. These front matter texts assist the user in situating this dictionary within the 
general South African lexicographic process. The question may be put why it has been deemed necessary to compile a dictionary of SAE. People asking such a question will most probably not use this dictionary. However, the front matter texts provide the intended target user of this dictionary with enough answers to this question. In this regard the text "English in South Africa" offers a brief but intriguing account of SAE. In this text the focus is on topics such as The coming of the English; Language status; The influence of English; Varieties of English; Influences on English and The future of English. This text also includes a list of references on the relevant topics. The inclusion of a text like this increases the added value of the DSAE because it offers the target user bonus information. The lexicographers have to be commended on the aptness of this text in a dictionary based on historical principles. For the non-South African who might be interested in SAE, this text enhances the access to SAE as a variety of English.

The uniqueness of SAE is not restricted to those lexical items used exclusively in this variety of English. In the front matter texts it is also emphasised that many words from the standard variety of SAE are used in senses which are perplexing to English-speakers elsewhere. In this regard the contribution of Afrikaans and Dutch is discussed. Attention is also drawn to the SAE borrowings from the indigenous languages. In addition to this information transfer, the text on the pronunciation of SAE gives evidence of one of the most salient differences between South African English and other varieties of English. The key to the pronunciation offered in the articles as well as the text on the styling conventions applied in DSAE are texts which assist the user in his endeavour to achieve an optimal retrieval of information.

From a user's perspective, however, one has to argue that the front matter of DSAE contains too little help for the user. Although this dictionary is aimed at a sophisticated user group, no lexicographer may rely on the intuition of the intended target users of the dictionary. A dictionary is a system and the way in which the various components fit into the pattern needs to be explained in order to enhance the retrieval of information. When consulting a dictionary the average user seldom utilises the information given in the front matter. This lack of a dictionary culture on the part of the user may not seduce the lexicographer to abstain from including sufficient guidelines for the target user in the front matter texts. It is important that the front matter should include a text focusing on user's guidelines in which an analysis of a typical article is presented. This will give the user an opportunity to become familiar with the search zones of the articles and with the specific article slot allocated to each information category. The user of DSAE has to guess that the front matter text "Styling conventions" contains the user's guidelines. In this text the different elements of an article (DSAE does not refer to "article" but rather to "entry") are discussed in the order in which they appear in the articles. The user would have had a clearer and more direct and immediate understanding of the article structure if DSAE could have included an example of an article in this text. This would 
have been in line with a well-established pattern which has been applied in many dictionaries.

Typical users of dictionaries are not aware of the typological criteria of a dictionary based on historical principles and the way in which such a dictionary fits into the broader typological frame. It is the responsibility of the lexicographer to explain this to the target users and to give an explicit account of the way in which an historical approach influences the structure of articles as well as the collection of macrostructural and microstructural entries. The text on styling conventions includes a paragraph on the ordering of senses. In this paragraph the editors do refer to the fact that each "entry" is chronologically arranged. In the paragraph on citations it is also mentioned that for each sense the citations are arranged in chronological order. It would, however, have been better to make an explicit statement on the microstructural implications of the typological category of DSAE. This would have enhanced the user-friendliness of this dictionary and would also have increased the ease of information retrieval.

\subsubsection{The back matter}

The back matter is an optional component of a dictionary and each text presented in this component can be regarded as a bonus. DSAE has one text included in the back matter, i.e. a select bibliography. This text contains a list of those works most commonly used in compiling the dictionary. The short preface to the bibliography, acting as a secondary level front matter text (cf. Gouws forthcoming), states it clearly that the list also includes works "about which it may be difficult to find information elsewhere". This functional value of the bibliography as an unintegrated outer text becomes apparent if one takes a look at the diverse nature of the cited texts and other sources. It gives access to old documents, unpublished titles as well as many other books and articles. From the perspective of a user consulting DSAE on account of its historical approach, this bibliography offers an added value. The preface of the back matter text explicates this added value by stating: "It is hoped that the bibliography will prove a useful tool for readers interested in South African texts." This is truly the case, and the bibliography can rightfully be regarded as an important collection of sources for researchers focusing on texts which are relevant to a study of the development of South African English.

\subsubsection{The central list}

For the average dictionary user the term "dictionary" refers primarily to the central list of this carrier of texts. Although the structure of the central list in DSAE is not explained sufficiently in the front matter texts, this component of DSAE has to be regarded as one of the most important texts in the collection of 
South African lexicographic works. This can be motivated on various grounds of which the most significant is the fact that DSAE reflects the reality, extent and use of SAE like no other lexicographic, reference or research source has done.

The central list does not only offer a macrostructural selection representing SAE as a well-defined variety of English, but the microstructural treatment contextualises these lexical items in their respective historical, stylistic, linguistic and pragmatic environment.

\subsubsection{The macrostructure}

Dictionaries are more often than not judged by the contents of their macrostructure. Typical remarks often made in this regard refer to the number of (new) words in a dictionary or the representativeness of the selection of words included in the macrostructure. Although being a single volume dictionary, DSAE presents a quite comprehensive selection of items from the lexicon of SAE. However, this dictionary is not directed at an account of that very large segment of SAE, which overlaps with other varieties of English. Therefore DSAE is not a dictionary presenting the full lexicon of SAE but primarily those words which are particular to South Africans. This includes, as is stated in the preface, "words borrowed from the many languages of South Africa, English words that have required particular senses here, and words coined for local phenomena". Some of the words in DSAE are not South African in origin, but have a particular significance for South Africans. This feature gives an added value to DSAE. It is not a dictionary to consult if you are looking for the ordinary lexical items of English. It is a dictionary aimed at the unique character of SAE. This implies that DSAE cannot be utilised as the only English lexicographic source for the average South African dictionary user. This user will still need a dictionary focusing on "general" English. However, for those persons interested in the differences between SAE and other varieties of English, DSAE is a source well worth obtaining.

Language borrowing is a universal phenomenon and owing to the status of English as an international language, the lexicon of English has to be regarded as one of the prime targets for language borrowing. The influence of borrowing on English, however, is not always realised by the average language user. The macrostructure of DSAE not only gives evidence of the massive influence borrowings have had on SAE, but it once again emphasises the aptness of Pettman's reference to South African words. DSAE makes pleasant and familiar reading for South Africans of different speech communities. This is due to the fact that SAE accommodates so many items from the lexicons of the other South African languages. One of he most significant features of the DSAE, is the lack of a purist bias. The consistent endeavour of the editors to present the full spectrum of the lexicon of SAE enhances the credibility of this dictionary. This endeavour is often in opposition to the prescriptive nature 
users attribute to dictionaries. Fortunately the editors of DSAE did not allow this prescriptive tradition to impede their selection of lexical items for lemmatisation. The following remark in the preface indicates their attitude to include both standard and non-standard forms: "Time and time again the Dictionary Unit has been accused of 'writing a dictionary of slang'. This dictionary does, of course, include colloquialisms, slang, and vulgarisms; however, it is hoped that readers will be presently surprised by the age, creativity, and variety of the standard variety recorded here."

From a thematic point of view the macrostructure, although alphabetically ordered, offers an interesting perspective on the lexicon of SAE as well as on that of the languages from which SAE has borrowed. So many borrowed SAE lexical items are informal names. In this regard the names can be directed to a wide variety of subfields, e.g. the names of animals, trees and plants, food and drinks, etc. These thematic borrowings give a clear indication of, besides the role of other indigenous languages, the extent of the influence of Afrikaans on $\mathrm{SAE}$. The Afrikaans linguist, student and researcher will benefit from the inclusion and treatment of numerous items from the Afrikaans lexicon in DSAE.

Given the political history of South Africa it is not surprising to find numerous political terms included in DSAE's macrostructure. Also in this regard the emphasis is not only on unique words but also on words with a unique South African meaning. Examples are:

comrades (usually in the plural as a collective term) Young, usually leftwing activists, particularly militant supporters of the African National Congress.

necklace A method of lynching or unofficial execution by placing a tyre doused or filled with petrol round a person's shoulders or neck and setting it alight.

One of the words omitted in DSAE is the lexical item struggle, which has been central in the political jargon of the past decade or two in referring to the fight against the previous political system.

As a container of linguistic information DSAE confronts the user already on the macrostructural level with the fact that word-formation processes of $\mathrm{SAE}$ also reflect the ongoing language contact in South Africa. Items like nownow ("in a moment/a moment ago") and play-play ("with ease/while playing") are typical results of the influence of reduplication which plays an active role in Afrikaans word-formation. The item yes-no (from the Afrikaans ja-nee; "sure/that's a fact"), used to qualify a response, is a typical example of two English items combined according to a non-English pattern, but interpreted and used without any problems in SAE.

The macrostructural selection in DSAE has to be regarded as the most comprehensive representation of SAE. Although this collection of items is of 
interest to lexicographers and linguists from the other South African languages as well as scholars from other varieties of English, English teachers and the teaching staff in English departments at South African universities should focus their attention on this work. These scholars have not always acknowledged the reality of SAE and its unique composition. Too often students get a distorted picture of the language, which is used as lingua franca in South Africa. It is important to become familiar with an international standard variety of English. However, from a communicative perspective it is just as important to master the variety, register and style of the majority of the local speech community. DSAE assists its users in achieving this goal.

\subsubsection{The microstructure}

The major difference between a word list and a more comprehensive dictionary is the fact that lemmata are presented in the latter source as treatment units, and this treatment implies the inclusion of a variety of comments on the macrostructural item. The typological classification of a dictionary should always play a decisive role in determining the nature, extent and presentation of the microstructure. Therefore it is so important for a lexicographer to utilise one of the front matter texts to give the target users guidance regarding the contents and ordering of the microstructure. In the front matter texts the information on SAE provides users with an indication of the macrostructural selection with which they will be confronted. The text on styling conventions helps the user to recognise the different types of microstructural categories presented in DSAE. This text gives a clear understanding of the density of information presented in the treatment of lemmata. Microstructural entries include pronunciation, part of speech, labels, variant spellings, morphological information, etymology, combinations and collocations, encyclopaedic notes and citations. Lemmata receive a comprehensive treatment and each information category is dealt with in exemplary fashion.

From the perspective of the dictionary user, it is significant to find such a variety of information categories in the articles. Since many of the lexical items included as lemmata will not be found in any other dictionary, it is important that DSAE should offer a comprehensive treatment, especially with regard to pronunciations, meaning and usage, because these are the unique features of this subsection from the lexicon of SAE.

The microstructural treatment presented in DSAE has to be regarded as an extremely valuable contribution to South African lexicography in general. This can be motivated on various grounds. Firstly, as a dictionary of SAE, DSAE fills a gap in the dictionary family and in the scientific account of SAE. Due to the "South African" rather than a restricted SAE approach, the presentation of lemmata is a clear exhibit of the linguistic interaction in a multilingual South Africa. In this regard it is good to know that an international language like English can also be on the receiving end in the process of language borrowing. 
The macrostructural selection in DSAE makes it easy for speakers of the other South African languages to identify with this dictionary. DSAE serves more than just a lexicographic, linguistic or communicative function. It also enhances a South African nationalism. A second point in question when evaluating the contribution of DSAE is the historical approach applied in this dictionary. In spite of all the other lexicographic endeavours in South Africa, there has been no successful attempt to publish a dictionary on historical principles. DSAE sets an example from which lexicographers from all the other languages will benefit greatly.

A third reason for a positive evaluation of DSAE's contribution to the South African lexicography can be found in the treatment of items with an Afrikaans origin. An investigation of the South African languages clearly shows that the Afrikaans lexicography is the most sophisticated. This applies to the nature and extent of the dictionary collection, especially the typological variety, as well as the lexicographic treatment. The most impressive Afrikaans lexicographic project is the comprehensive multi-volume Woordeboek van die Afrikaanse Taal (Dictionary of the Afrikaans Language). For Afrikaans linguists this dictionary, commonly referred to as the WAT, is a valuable source of information. Although it may sound contradictory, the WAT, in spite of being a comprehensive dictionary, is also a synchronic dictionary. Older words are included in the macrostructure and many citations come from older sources. The approach, however, is not historical and the WAT fails to assist the Afrikaans linguist or researcher who is looking for historical information (cf. Gouws and Ponelis 1992). In this regard DSAE fills a noticeable gap in Afrikaans lexicography. The record of so many older lexical items, their diachronic treatment and the accompanying etymological information already serve as a valuable contribution to the study of Afrikaans. DSAE's historical approach in the ordering of senses and especially in the presentation and chronological ordering of citations, gives the Afrikaans linguist a systematic access to information previously restricted to a random collection of sources.

\section{In conclusion}

DSAE is a dictionary, but it is also more than a dictionary. It contains a lexicographic treatment which is exemplary both on macrostructural and microstructural level. It contributes both to the English and the general South African lexicography and offers valuable information to researchers and linguists of all the South African languages. The historical approach and the comprehensive treatment of lexical items from different varieties of SAE make this dictionary a document worth the attention of scholars interested in historical linguistics, language contact, sociolinguistics and the dynamics of language change.

DSAE is both compact and comprehensive. It focuses exclusively on that subsection of the lexicon of $S A E$, which represents the uniqueness of this variety of English. It is compact in its treatment of items although the density of 
information is high due to a good variety of information categories presented in each article. This is a highly successful lexicographic endeavour which fills a very specific niche in the South African lexicographic process.

\section{Bibliography}

Anonymous (S.J. du Toit). 1902/1904. Patriot Woordeboek/Patriot Dictionary. Paarl: D.F. du Toit.

Bergenholtz, H., S. Tarp and H.E. Wiegand. 1999. Datendistributionsstrukturen, Makro- und Mikrostrukturen in neueren Fachwörterbüchern. Fachsprachen. Languages for Special Purposes. An International Handbook of Special-Language and Terminology Research. Berlin: De Gruyter: 1762-1832.

Branford, J. and Branford, W. 19914. A Dictionary of South African English. Cape Town: Oxford University Press.

Branford, W. 1987. The South African Pocket Oxford Dictionary. Cape Town: Oxford University Press.

Changuion, A.N.E. 1844. Proeve van Kaapsch Taaleigen. Changuion, A.N.E. 1844. De Nederduitsche Taal in Zuid-Afrika Hersteld. Cape Town: J.H. Collard.

Gouws, R.H. and F.A. Ponelis. 1992. The Development of Afrikaans and the Lexicographical Tradition. Zgusta, L. (Ed.). 1992. History, Languages and Lexicographers: 77-104. Tübingen: Max Niemeyer.

Gouws, R. H. 1995. Dictionaries and the Dynamics of Language Change. Kachru, B. B. and H. Kahane (Eds.). 1995. Cultures, Ideologies, and the Dictionary: 297-313. Tübingen: Max Niemeyer.

Gouws, R.H. Forthcoming. Mediostructural Representation, Textual Condensation and User-Orientation in the WAT X. Lexicographica 15.

Hausmann, F.J. and H.E. Wiegand. 1989. Component Parts and Structures of General Monolingual Dictionaries. Hausmann, F.J. et al. (Eds.). 1989-1991. Wörterbücher/Dictionaries/Dictionnaires: 329-360. Berlin: Walter de Gruyter.

Kammerer, M. and Wiegand, H.E. 1998. Über die textuelle Rahmenstruktur von Wörterbüchern. Präzisierungen und weiterführende Überlegungen. Lexicographica 14: 224-238.

Mansvelt, N. 1884. Proeve van een Kaapsch-Hollandsch Idioticon met Toelichtingen en Opmerkingen betreffend Land, Volk en Taal. Cape Town: Van de Sandt de Villiers.

Pettman, C. 1913. Africanderisms. London: Longmans, Green \& Company.

Van Schalkwyk, D.J. et al. (Eds.). Woordeboek van die Afrikaanse Taal. Stellenbosch: Bureau of the WAT.

Wiegand, H.E. 1989. Der gegenwärtige Status der Lexikographie und ihr Verhältnis zu anderen Disziplinen. Hausmann, F.J. et al. (Eds.). 1989-1991. Wörterbücher/Dictionaries/Dictionnaires: 246-280. Berlin: Walter de Gruyter. 


\title{
Portals to Knowledge: CD-ROM Encyclopaedias, with Specific Reference to Microsoft Encarta 99 Encyclopedia
}

Phillip Adriaan Louw, Department of Afrikaans and Dutch, University of Stellenbosch, Stellenbosch, Republic of South Africa

\begin{abstract}
The close interaction between linguistics and lexicography over the last few decades has had many good effects, not least of which has been the development of a theoretical framework or metalexicography. However, this close link has had an unfortunate result: the marginalisation in the theoretical debate of nonlinguistic dictionaries and especially of the encyclopaedia.

In this article, semantic, lexicographical and pragmatic motivations will be given for a renewed interest in encyclopaedias. The revolution caused by CD-ROM encyclopaedias and the benefits they hold for a large spectrum of users, will be the most important pragmatic motivations addressed. Microsoft Encarta 99 Encyclopedia will act as a guide for the exploration of the impact this revolution has had on the ideas of user-friendliness and dictionary accessibility. Finally, a future is envisioned in which the Internet will be the logical culmination of the ultimate potential of computers as accessible, user-friendly reference tools.
\end{abstract}

Keywords: ACCESS STRUCTURE, ACTIVE CROSS-REFERENCES, CD-ROM ENCYCLOPAEDIA, DICTIONARY ACCESSIBILITY, ENCYCLOPAEDIA, GUIDE STRUCTURES, INNER ACCESS STRUCTURE, INNER SEARCH PATH, INTERNET, LINGUISTIC DICTIONARY, MEDIOSTRUCTURE, MULTIMEDIA, NONLINGUISTIC DICTIONARY, OUTER ACCESS STRUCTURE, OUTER SEARCH PATH, PASSIVE CROSS-REFERENCING, USER-FRIENDLINESS

Opsomming: Poorte na kennis: CD-ROM-ensiklopedieë met spesifieke verwysing na Microsoft Encarta 99 Encyclopedia. Die noue interaksie tussen die linguistiek en die leksikografie het in die laaste paar dekades reeds baie goeie gevolge gehad, met die totstandkoming van ' $n$ teoretiese raamwerk of metaleksikografie as seker die prominentste uitvloeisel. Hierdie wisselwerking het egter tot 'n ongelukkige gevolg gelei: die marginalisasie van nielinguistiese woordeboeke en veral ensiklopedieë binne die teoretiese debat.

In hierdie artikel sal semantiese, leksikografiese en pragmatiese motiverings aangebied word vir ' $n$ hernieude fokus op ensiklopedieë. Die revolusie wat deur die CD-ROM-ensiklopedieë veroorsaak is en die voordele wat hulle vir 'n wye spektrum gebruikers inhou, is die belangrikste pragmatiese motiverings wat bespreek sal word. Microsoft Encarta 99 Encyclopedia sal optree as gids by die ondersoek na die impak wat hierdie revolusie op die beginsels van gebruikersvriendelikheid en woordeboektoeganklikheid het. Laastens word 'n blik op die toekoms gebied waarin die Inter- 
net as die logiese bereiking van die potensiaal van rekenaars as toeganklike, gebruikersvriendelike naslaanbronne in die vooruitsig gestel word.

Sleutelwoorde: AKTIEWE KRUISVERWYSINGS, CD-ROM-ENSIKLOPEDIE, EKSTERNE SOEKROETE, EKSTERNE TOEGANGSTRUKTUUR, ENSIKLOPEDIE, GEBRUIKERSVRIENDELIKHEID, GIDSSTRUKTURE, INTERNE SOEKROETE, INTERNE TOEGANGSTRUKTUUR, INTERNET, LINGUISTIESE WOORDEBOEK, MEDIOSTRUKTUUR, MULTIMEDIA, NIELINGUISTIESE WOORDEBOEK, PASSIEWE KRUISVERWYSINGS, TOEGANGSTRUKTUUR, WOORDEBOEKTOEGANKLIKHEID

\section{Introduction}

The interaction between linguistics and lexicography has been fruitful through the years. This partnership has led to the birth of a theoretical framework or "metalexicography" (Wiegand 1984: 15) within which it is possible to survey "the history of lexicography" and learn from it, establish "a general theory of lexicography", do "research on dictionary use" and critically evaluate dictionaries. In Wiegand's general theory of lexicography, dictionary typology is viewed as "a major component ... since many of the statements in this theory have to be formulated relative to the typology" (Wiegand 1984: 17). This claim is supported by the current emphasis in meta- and practical lexicography on the needs of the dictionary user.

The guiding principle of user-friendliness dictates that a lexicographer should have a set group of target users in mind before working out the theory of organisation and accompanying typological profile of a dictionary. According to Al-Kasimi (1977: 18) dictionary typology is inseparable from the purpose of a dictionary which in turn is determined by "the needs of the target user" (Gouws 1989: 66). Sadly, the very close relationship between linguistics and lexicography has had a negative, user-unfriendly effect in the current metalexicography. The nonlinguistic dictionary and especially the encyclopaedia a valuable, widely-used reference work - has been marginalised as a result of the linguistic bias. This article aims to partially correct this imbalance.

There has, however, been a call for a more representative typology from many sources. Even though the nonlinguistic dictionary has not received much metalexicographical attention, it has been included in dictionary typologies as an opposite to linguistic dictionaries. The encyclopaedia is seen as the prototypical nonlinguistic dictionary; in fact various metalexicographers view the distinction between the encyclopaedia and the linguistic dictionary as one of the most elementary typological distinctions (see Gouws 1989: 60, Landau 1984: 5 and Zgusta 1971: 198). Svensén (1993: 2) locates the difference between these types as inherent in the nature of the information they present: "an encyclopaedia communicates knowledge about the world, whereas the (linguistic) dic- 
tionary gives information about the individual units in the communication system (i.e. the language)". Gouws (1989: 60) describes the difference in terms of the motivation for the compilation of the reference tool. The encyclopaedia must serve broader cultural needs, whereas a linguistic dictionary is constructed with linguistic purposes in mind.

There are not necessarily fixed boundaries between these two. Encyclopaedic information is for example often found in general monolingual dictionaries. The cognitive school's emphasis on the role of pragmatic information in the construction of meaning indicates a further bond between what is traditionally seen as linguistic information and encyclopaedic information. Contextual information that does not form part of a strictly semantic analysis of a given lexical item, does however have semantic value within the broader framework of meaning a speaker constructs for him-/herself. The encyclopaedia and the linguistic dictionary should then be seen as two points on a scale with nondiscrete boundaries. Much more effort should also be made to explore the lexicographical relevance and value of the encyclopaedia.

\section{Encyclopaedias}

Besides this view on the construction of meaning there are also other reasons why more attention should be paid to encyclopaedias in metalexicographical circles. Gouws (1989: 61) states: "The accommodation of encyclopaedias in the dictionary family follows from the principles of arrangement (of entries etc.) that are employed in encyclopaedias and that are motivated by lexicographic criteria" (my translation). More will be made of this in the discussion of guide structures in Microsoft Encarta 99 Encyclopedia (henceforth Encarta 99).

Encyclopaedias also warrant more attention for a pragmatic reason. Next to general dictionaries, general family reference encyclopaedias are probably the most widely-used, influential reference sources, particularly for younger users. Technological advances have made encyclopaedias even more prominent reference sources. With the advent of the computer age, encyclopaedias are no longer solely available as overpriced, oversized, cumbersome multivolume books. CD-ROM encyclopaedias are generally not larger than $C D$ ROM dictionaries and are not more expensive. For those who can afford a computer, these encyclopaedias can be powerful resources of valuable information. A school pupil, for example, will not have to go through the torturous experience of library visits, difficult search routes through several volumes and often more than one copying and/or photocopying session. All the information he/she requires (including pictures) is available at home on computer. These developments do not however render their predecessors obsolete, and there will probably still be a market for printed dictionaries and encyclopaedias for a very long time. 


\section{General family reference encyclopaedias on CD-ROM}

The commercial sector has long since seen the potential of computerised innovation. Several encyclopaedias are currently competing on the computer market, including products made by Grolier and Compton from the United States of America and encyclopaedias by Hutchinson and Oxford in Great Britain. Yet one of the most successful family reference works is brought to the market by Microsoft, the creators of the Windows interface and operating system.

Most of these encyclopaedias, including Microsoft Encarta, have been available for some time, and with a new, updated version appearing every year the compilers have taken care to maintain the pace and gain any possible advantage over competitors. The result is that Encarta 99 is a formidable opponent combining the latest technology with a solid, well-researched informative text as part of the microstructure.

\section{The microstructure}

In this article the central focus is on the ways in which Encarta 99 guides the user to the required information and not on the information itself. The microstructure does however reveal a relevant aspect of this encyclopaedia: who its target users are. This task should be performed by the introduction in the help (or overview) files and/or by an opening statement in the additional instruction booklet, but sadly it is not done. Should one then not assume that a general family reference encyclopaedia should meet the needs of the whole family? This is certainly the ideal, but does not reflect reality. The possible age span of a family and the specific requirements of each family member make it virtually impossible to meet the needs of for example the preschool, primary school, secondary school, tertiary student and professional adult member of the family in one CD-ROM encyclopaedia.

Encyclopaedias do tend to focus on specific target groups. The complexity and information density of the microstructure of for example Compton's New Century Referenice II (henceforth abbreviated as Compton's) seem to suggest tertiary students as its focus group, whereas the 1997 Grolier Multimedia Encyclopedia (henceforth Grolier) probably aims primarily at secondary school pupils. Encarta 99's text is the most versatile of the three, making it accessible to target groups from late primary school level up. PC Pro (1997: 215) comments on this element in Encarta 98:

Many articles have been restructured and rewritten to make them more appropriate to either primary or secondary school use. Look up "castle", for example, and you'll find an article written in relatively straightforward language, appropriate to a typical primary school project. Go for something more complex like "quantum theory", and all the terminology 
and ideas are presented using advanced language appropriate to secondary school or college users.

Encarta also employs an easily accessible and understandable dictionary that can help to explain difficult words in the microstructure. One might then expect the same versatility to be employed in the "guide structures" (see Louw 1998: 97) of this encyclopaedia. Generally this is so, but it is not always the case.

\section{Guide structures in Encarta 99}

In keeping with the broad theme of user-friendliness it is apt that a discussion of a computerised nonlinguistic dictionary should focus on those elements that have revolutionised the way lexicographers think about dictionary accessibility. In a written dictionary or encyclopaedia the search paths users follow to the information they require are almost always relatively slow. Louw (1998: 97144) shows that lexicographers' creative use of guide structures such as the access, addressing and mediostructures, and functional help texts such as indexes, user's guides, abbreviation lists, etc., can speed up the searches. Yet the restrictions of the book format limits the ingenuity of the lexicographer much more than the freer approach allowed by the computer.

Two of the guide structures mentioned above, the access structure and mediostructure (the structure encompassing all lexicographic cross-references), will be used in the rest of this article to illustrate the tremendous potential of the CD-ROM encyclopaedia and the successes and shortcomings of Encarta 99.

CD-ROM encyclopaedias seem to be the state of the art in accessibility and linking of material. This is probably the result of the urge to continuously improve the product and to keep one step ahead of the competition. Therefore the scope of the terminology used for printed dictionaries will have to be broadened considerably. For example, the mediostructure has to accommodate the hyperlinks between CD-ROM and the Internet facilitated by the hard drive. This development has significantly altered the concepts of intertextuality and cross-referencing (more about this later). Yet the existing terminology still provides a valuable framework within which to discuss Encarta 99. Consider for example the theory of the access structure.

\section{Access structures in Encarta 99}

The route to the information desired can still be subdivided into an outer search path and an inner search path. The former takes the user to the desired article while the latter refers to the search conducted in the microstructure to find relevant pieces of information. The structures that are set up to guide the users on these paths by simplifying access to the necessary information are the outer and inner access structures. 


\section{The outer access structure}

It is the outer access structure that provides the first proof of the CD-ROM encyclopaedia's potential. The rapid outer access structure which encompasses those elements that guides one up to the lemma, needs to be very well constructed. Successful, easy access is imperative in this very early part of the user's search for the required information. The opening screen of Encarta 99 already provides the user with immediate access to the encyclopaedia articles as main macrostructure or direct links to the accompanying dictionary, on-line updating facilities, help (or overview) files or to the inserted media texts (which can be accessed either as inserted inner texts in the encyclopaedia articles or in this case as independent lists organized into different categories). Encarta 99's opening screen is an attractive, well-designed first stop on the rapid outer search path.

If one chooses to go directly to the encyclopaedia articles there is yet another excellent element of the rapid outer access structure to guide one, viz. the pinpointer. This floating help text acts as an index in which all the encyclopaedia articles are presented. One can simply browse through the list using one's mouse and click on the relevant article to display it on the main part of the screen, or even easier, type in the required article name and press the enter key to automatically display the article. If the topic one is searching for is not worded as in the entries in the alphabetical list, there is also a word search feature in the pinpointer. The results of simple word searches are however often haphazardly arranged and one might have to wade through irrelevant material before arriving at the required article. The help files in Encarta does, however, give the user a detailed account on how to use the different and sometimes complicated search methods. To some extent this makes up for the lack of organization in the results of simple searches, because guidelines are given to help the user refine the search and go directly to the relevant information. With the current emphasis on an immediate transfer of information, the question remains whether a family research encyclopaedia should assume that its users will study the user's guide or help files before starting their searches. The creators of Encarta can learn much from the organized, efficient searches allowed in Compton's idea search subsection.

The two encyclopaedias mentioned above and Grolier might differ on the format of especially the rapid outer access structure, but with the standard outer access structure (which corresponds to the main macrostructure in each encyclopaedia) the procedures followed are very similar. They all, for example, employ an initial alphabetical listing of articles rather than a thematic listing as is used by the creators of the electronic version of the American Concise Encyclopaedia. For the more crafty researchers Encarta 99 offers a secondary thematically structured search path. One can enter this search path by clicking on the button marked categories on the right hand side of the pinpointer. A list of broad thematic groupings will appear to the right, which can be refined yet again 
before a final list of results is given in the main window of the pinpointer in alphabetical order. This versatility in its outer access structure shows Encarta 99's commitment to meeting the needs of its broad group of target users. Yet it is the preference for an initial alphabetic listing as the first step in searches using the pinpointer, that proves this commitment to the needs of target users, as an alphabetical listing would probably be preferred by families within the current dictionary culture. The adherence here to lexicographic criteria corresponds with Gouws's $(1989: 61)$ motivation for including encyclopaedias in the dictionary family.

\section{The inner access structure}

The principle of user-friendliness also guided the compilers in their creation of the inner access structure. The most innovative part of Encarta 99's inner access structure is the outline given with subdivided articles. If one looks up "dictionary" one would find an outline containing a general introduction and four subheadings "Encyclopedic Dictionaries", "Earliest Dictionaries", "Major Dictionaries of Continental Europe" and "Dictionaries in the English Language". By engaging the outline + text option at the view function the user can ensure that the outline will be present at the left side of the screen for as long as he/she wants it there. In articles that are not subdivided that portion of the screen will remain empty. A most welcome addition is that a click on the desired subsection in the outline will move the main text to that point as well. This is useful in very long articles such as the one on World War II.

Another view option is to have the relevant media elements in smaller size on the screen at the same time as the outline and the main text. This may however lead to a very crowded display that defies the principle of user-friendliness. The outline can therefore be removed, leaving only the media element and main text. One can of course exercise the option of having only the main text or the media element on screen, if so desired.

Another important aspect of the inner access structure, is the easy access to the media elements either from the main text (where they operate as hidden inserted inner texts easily accessible by means of a double click on a relevant icon), or from the outline. The availability of media features in the outline can save a prolonged search through the main text and is one of Encarta 99's unique features.

Yet it is this same interaction between media elements, outline and main text that leads to one of the user's greatest frustrations. The inner search path is often rudely interrupted when one is calling up media elements by a prompt to change the CDs. Owing to Encarta's size it had to be accommodated on two CD-ROMs. The Deluxe edition adds a third with an enhanced search engine called a research organiser which is "great for school projects" (Hardaker 1997: 23) and teaches students the research skills they need to deal with vast amounts of information. The changing is inevitable, but a more systematic approach as 
to which media elements are on which $C D$ would be welcome. At the moment certain media elements (even of the same type) in a given article are on one $C D$ and the rest on the other. The confusion is compounded by the fact that no explanation or policy statement regarding the distribution of material on each $\mathrm{CD}$ is given in the help files. This situation should be remedied before new editions of Encarta appear.

\section{The mediostructure}

Innovation in lexicographic practice is not limited to the outer and inner access structures. Encarta 99 also takes the art of lexicographical cross-referencing to new heights. Certain words in the main text are displayed in red and a click on one of these transports the user to another related article. In the article with "dictionary" as lemma, one would find in the subsection "Dictionaries in the English Language" the name "Noah Webster" in red. A click on these words takes the reader to an article on his life's work. A click on the icon denoting back then guides the user back to the previous article "dictionary", if he/she wishes to go there. Encarta 99's cross-references are not only clearer than e.g. Compton's or Grolier, but "compared with the other two it also has more hypertext links within articles which take you to other, relevant articles" (Hardaker 1996: 46).

Unlike passive cross-referencing in printed dictionaries these active crossreferences provide the user with direct access to the required information. This increases the speed of the search, saving the user time and effort. The innovation does not stop with these cross-references to extemal articles though. Encarta 99 expands the bounds of intertextuality by employing active textexternal cross-references which would have been impossible in books. Firstly, one can click on almost any word in the main text of an article that is not a name and be greeted by a concise definition courtesy of Encarta's borrowed, integrated dictionary (in this World English Edition of Encarta 99 the 9th edition of the Concise Oxford Dictionary).

Secondly, several articles (see for example "World War I") include an icon that if clicked on calls up a relevant segment of text in the broader text called the timelines. These segments are not inserted texts, because the whole timelines text is active at the time it is displayed on screen (which is not necessarily the case when a map is inserted from the atlas). The timelines link is therefore an effective active article-extemal text-extemal cross-reference.

As active encyclopaedia-extemal cross-references, Encarta 99 offers (as does most of its competitors) links to the Intemet. Hardaker (1996: 42) states about these encyclopaedias: "In their latest incamations they connect to on-line services and thus automatically update themselves". Laborious supplements are replaced by swift, monthly updates to ensure that the user stays in touch with the ever-changing reality. 
The more internal references (especially the article-internal references) are not to be outdone, however, by those covering greater distances in the search path. As has already been shown, the active cross-references in the outline can save the users time in their inner search path and are mostly direct and relevant. The exception is once again active cross-references (especially to multimedia inserted texts) that lead to a prompt for a change of CDs, but even with this minor delay the user still gets to the required information faster than with any printed encyclopaedia.

Active cross-references, as employed in Encarta 99, should also form part of a discussion of the future of linguistic dictionaries. It is one of many new ideas that make general linguistic dictionaries on CD-ROM or the Internet exciting new tools especially for those who work with a word processor. Whereas monolingual descriptive English dictionaries are already well represented on CD-ROM (with the first Afrikaans standard descriptive CD-ROM dictionary recently having appeared), translation dictionaries are not readily available yet. There is for example a dire need for such a dictionary with Afrikaans and English as treated language pair, which can be consulted when using a word processor.

\section{Other helpful additions}

In addition to the revolution in guide structures such as the access and mediostructure, CD-ROM encyclopaedias have also brought a new dimension to the main text, either to help the user to understand the program or decode the main text or to help the user by providing additional information to the main text. Multimedia has provided these texts with the benefit of sound and in some cases video. Probably the best illustration of the added value is provided by those media elements acting as inserted inner texts.

\section{Inserted inner texts}

These easily accessible texts come complete with captions that often summarize relevant parts of the main text article. The inserted texts can act independently, but are at best employed in co-operation with the main text. If one goes to the article on World War II one finds a vast array of media elements, including several photographs, audio texts (e.g. on the signing of the Munich Pact), tables, etc. The Deluxe edition even includes sidebars, inserted texts that are easily accessible from both the main text and the outline and "include personal essays, topical news stories, case histories, or other interesting and unique viewpoints on the topic you're exploring" (Encarta 99 Deluxe User's Guide, 17). In the above-mentioned article one finds several of these texts that provide a unique, undiluted view of the war. A student can for example access King 
George VI's broadcast on the eve of war, Roosevelt's Pearl Harbour speech or the English text of the German surrender at Reims.

In some cases these inserted media elements form part of other texts. If one calls up "South Africa" in a separate search for example, a map of South Africa is available as an inserted text. This map is part of a complete atlas which is included on the CD and can be accessed as a whole from the media gallery. These inserted texts together with the integration of other texts such as the dictionary, interactivities and timelines, as well as the virtual tours of the Deluxe edition, prove that the encyclopaedia is not a text, but a complex text type carrier which allows free movement between its constituent texts. Though this is often also the goal of the printed (linguistic or nonlinguistic) dictionary the freedom of access granted by the computerized format means that a CDROM encyclopaedia such as Encarta 99 comes much closer to reaching this goal.

\section{Towards the future}

From this article the tremendous advantages offered by CD-ROM encyclopaedias should be apparent and yet they are already under threat of being surpassed by the Internet. At the moment computer users in search of nonlinguistic dictionaries make do with CD-ROM encyclopaedias or encyclopaedia downloads from the World Wide Web. With the improvements being made on the search engines of the Internet to make search paths faster, together with the availability of books, audio and video texts on the Internet, it is conceivable that the Internet can function as an almost limitless encyclopaedia. With its tremendous speed and information storage capacity, this "encyclopaedia" can dwarf printed and CD-ROM versions and redefine our concept of traditional lexicography. It also offers practical lexicography and metalexicographers a world of new opportunities if they can detach themselves from a linguistic bias as well as conquer the technology of the computer.

\section{Bibliography}

\section{Encyclopaedias}

American Concise Encyclopedia on Power CD. 1995. ZCI Publishing Inc.

Compton's New Century Encyclopedia and Reference Collection II. 1995. Compton's New Media Inc.

1997 Grolier Multimedia Encyclopedia. 1997. Grolier Interactive Inc.

Microsoft Encarta 99 Encyclopedia. 1998. Microsoft Corporation. 


\section{Other sources}

Al-Kasimi, A.-M. 1977. Linguistics and Bilingual Dictionaries. Leyden: E.J. Brill.

Gouws, R.H. 1989. Leksikografie. Cape Town: Academica.

Hardaker, M. 1996. CD-ROM Encyclopaedias. S.A. Conputer Magazine, September 1996: 40-48.

Hardaker, M. 1997. Encarta 98. @ home, November 1997: 23.

Hartmann, R.R.K. (Ed.). 1984. LEXeter '83 Proceedings. Tübingen: Max Niemeyer.

Landau, S. 1989. Dictionaries: The Art and Craft of Lexicography. Cambridge: Cambridge University Press.

Louw, P.A. 1998. Kriteria vir 'n standaard vertalende woordeboek. Unpublished M.A. thesis. Stellenbosch: University of Stellenbosch.

PC Pro, Issue 38, December 1997: 215.

Svensén, B. 1993. Practical Lexicography. Oxford: Oxford University Press.

Wiegand, Herbert E. 1984. On the Structure and Contents of a General Theory of Lexicography. Hartmann, R.R.K. (Ed.). 1984: 13-30.

Zgusta, L. 1971. Manual of Lexicography. The Hague: Mouton. 
Joyce M. Hawkins (Compiler). The South African Oxford School Dictionary, 1996, xxi + 551 pp. ISBN 019571414 8. Cape Town: Oxford University Press. E-mail: oxford@oup.co.za. Price R44,95.

Preparing a dictionary for school children confronts the compiler with at least two problems. The first is how to simplify complex definitions, using a limited vocabulary; the second is what words to put in, and what to leave out. Indeed, how does one begin to assess what words South African school children currently live with? Cyberspace? No, apparently not; ecstasy as drug? No; rave as party? No again; gothic as a fashion statement? The only reference to gothic refers to a style of architecture "with pointed arches and much carving".

It is, of course, very easy to list words that do not appear in dictionaries, especially ones written for children. On the other hand, unless the compiler of such a dictionary has a very clear idea of what children think about, what they do, and how they react to the world around them, it is possible that the resultant dictionary may appear out of touch and out of date.

The South African Oxford School Dictionary has a sense of out-datedness about it. While it would be absurd to demand that a dictionary for schools should be up to date when new words are pouring into English all the time, one would hope that the world of the nineties was somehow reflected in its pages, rather than, perhaps, the world of a previous decade. The Preface delights in announcing that words like glasnost, greenhouse effect, and ghetto-blaster are included, describing them as "words and phrases that are considered new". Not any more, they aren't; not even when this dictionary was first published. There is no entry under Internet, website, and interactive, all words that have been heard in primary school halls (though there is CD-ROM, mouse and icon).

Then, too, there is always the question of whether to include the "rude" words of the language in a dictionary for children. Words related to matters of sex do appear, and their definitions are here as objective as such definitions can be. Masturbate is no longer defined with tones of judgement ("self-abuse" as my school dictionary had it); homosexual is defined quite simply as "attracted to people of the same sex", but lesbian is defined as "a homosexual woman", a definition lesbians are likely to take exception to. There are no swear words. Their inclusion is a matter for serious debate, it is true, but there is nevertheless an element of prissiness about their complete absence. Children today are so familiar with so-called swear words (like shit and arse and cock) that not to include them, even with a slang annotation, seems like censorship. Bum "a person's bottom" is annotated slang, which is laughable. The dictionary is a sanitised affair in this respect, and as such, it fails to capture fully the English South African school children are in daily contact with.

As regards the "South African" claim, there is a good spread of words of local provenance. Missing, though are Coloured, Kaffir, Black and White (the last two when used to describe race groups). Their absence again raises the question of the extent to which dictionaries for children only describe word usage - as one would hope a dictionary for adults does - or whether pre- 
scription begins to play a part, together with all the attendant moral and ideological undertones. Of course such words are offensive; of course one does not want children using them. But neither of those issues should affect a dictionary compiler. And since this dictionary has little "usage" paragraphs after potentially contentious entries, like the excellent little one after he that clarifies the need for non-sexist language, similar usage paragraphs dealing with racism after racist terms would have been educationally sounder than merely omitting the offensive terms. There is a strong whiff of more sanitising here.

The problem of defining words with a somewhat limited vocabulary at one's disposal has been handled here with skill. The definitions in this dictionary are, for the most part, precise, accurate and clear. Eschewing complexity, though, sometimes produces definitions that are not entirely helpful. Under Marxism we read "the Communist theories of the German writer Karl Marx ...". This necessitates looking up Communist, for without understanding that word, the definition is entirely useless. The word, of course, appears under the entry for Communism, and so, often missed by young users of dictionaries: "a political system where the State controls property, production, trade, etc.". Naturally, such a generalisation does not give a clear enough picture of the concept, nor, indeed, does it help in further understanding the difference between Marxism and Communism. The user will be left with the assumption that they are the same. On the other hand, ecology is defined with simplicity and precision.

You really cannot win in compiling a school dictionary: put in certain words, and there is criticism; leave them out, and there is criticism. As a onetime teacher, my feeling about such dictionaries was, simply, not to use them. Too much is lost of the complexity and the richness of the language in the necessary compromise with simplification and appropriateness. There are no etymologies, and yet some etymologies fascinate children. There are no illustrations, and, given the massive influx of CD-ROM encyclopaedias and reference collections, dictionaries of this kind should be doing something to make themselves a little more attractive to the young mind, bombarded as it is by visuals, colour, sound and movement.

The South African Oxford School Dictionary is one of the better dictionaries in this category. But it needs to rethink its sanitised content, its lacklustre look, and its feel of not really being in touch with its proposed readers. Much of this is due, no doubt, to the pursuit of producing the book as cheaply as possible (no illustrations, cheap paper, no colour, space saving by omitting etymologies). But I remain uncertain as to whether there is any sound reason for its being so conservative in its content.

Nigel Bakker

Senior Lecturer

School of Education

University of Cape Town

Rondebosch

Republic of South Africa 
Nasionale Terminologiediens van die Departement van Kuns, Kultuur, Wetenskap en Tegnologie. Drukkerswoordeboek / Printing Dictionary, Afrikaans-English / English-Afrikaans, hersiene uitgawe, 1995, xviii + 309 pp. ISBN 0-621-17323-1. E-pos: asteyn@print.pwv.gov.za. Pretoria: Staatsdrukker. Prys R20,20.

Aangesien die resensent nie ' $n$ taalkundige is nie, word die volgende resensie gelewer slegs uit die oogpunt van 'n kundige op die gebied van die drukkersbedryf.

In 'n poging om perspektief te kry op wie hierdie publikasie gerig is, behoort ' $n$ mens jou die volgende vrae af te vra alvorens ' $n$ kritiese oorsig werklik moontlik is: Wie is die gebruiker van die woordeboek - is dit student, vakleerling, dosent of is dit aldrie? Wie is die spesifieke teikenmark? Die beantwoording van hierdie vrae sou sekerlik die hele aanslag, styl en uitleg van die werk beinvloed. So mag dit eintlik vir die leek, wanneer dit by vertaling kom, taamlik verwarrend voorkom wanneer slegs die Afrikaanse ekwivalent van woorde gegee word, ofskoon rededele wel in sommige gevalle aangedui word.

Die uitleg van die bladsye maak dit maklik leesbaar, so ook die gebruik van die spesifieke lettertipe. Engels en Afrikaans kan maklik van mekaar onderskei word. Die gebruik van vet en kursiewe letters word op standaardleksikografiese wyse aangewend.

Die uiteensetting oor die gebruik van die woordeboek soos vervat in die "Verduidelikende Aantekeninge" voor in die boek vergemaklik die hantering daarvan vir die gebruiker. Ten opsigte van die inhoud is daar heelwat verbetering op die vorige publikasie - Drukkersterme (1971).

Dit is wel so dat trefwoorde met verskillende betekenisse onder mekaar geplaas word, soos vermeld onder punt $8, \mathrm{bl}$. $\mathrm{x}$ van die "Verduidelikende Aantekeninge". Vollediger aantekeninge in die teks sou egter van groter waarde wees. Verduidelikende frases kon in sulke gevalle gebruik gewees het.

Bondige definisies in die geval van moeilike of verwarrende terme sou nuttig te pas kom, bv.

duotone: Colour reproduction from monochrome original produced by making two halftone negatives for opposite ends of grey scale at proper screen angles, and plates etched to present proper tone and colour values. Keyplate usually printed in dark colour for detail while second plate is printed in light flat tints.

gutter: Space between pages in the printing forme of a book, etc., for folding and binding, i.e., the inside margin towards the back or binding edge.

French fold: Folder with an advertising message or announcement, printed on one side of a sheet folded once horizontally and once vertically. Thus, while there are eight pages in the folder, only the four outside ones $(1,4,5,8)$ are printed. 
galley: Flat oblong tray into which composed matter is put and kept until made up into pages in the forme.

progressive proof: Set of colour proofs consisting of proofs of each plate, single and in combination with other colours as the job will be printed.

Bogenoemde definisies word slegs as enkele voorbeelde gebruik en is ontleen aan Elsevier's Dictionary of the Printing and Allied Industries.

Daar bestaan geen twyfel oor die vakkundige korrektheid van die vertalings nie, daar dit deur die Nasionale Terminologiediens saamgestel is. Alhoewel die resensent besef dat hierdie slegs 'n tweetalige en nié 'n verklarende woordeboek is nie, word die volgende tog gestel:

Die gebruik van verbandswoorde in kursief aan die doeltaalkant van sekere woorde, soos verduidelik in punt $7, \mathrm{bl} . \mathrm{x}$, word verwelkom aangesien dit die konteks van die woord maklik identifiseer. Die vraag ontstaan egter of dit nie van meer waarde sou wees indien die vak-, ambag- of spesialiteitsrigting aangedui kon word nie.

Wat gebruikersvriendelikheid betref, sou 'n afsonderlike lys afkortings nie nuttiger en geriefliker wees in plaas daarvan dat hulle alfabeties tussen die ander terme ingesluit is nie? Afkortings wat alledaags in die bedryf gebruik word, maar nie in die woordeboek opgeneem is nie, is bv.

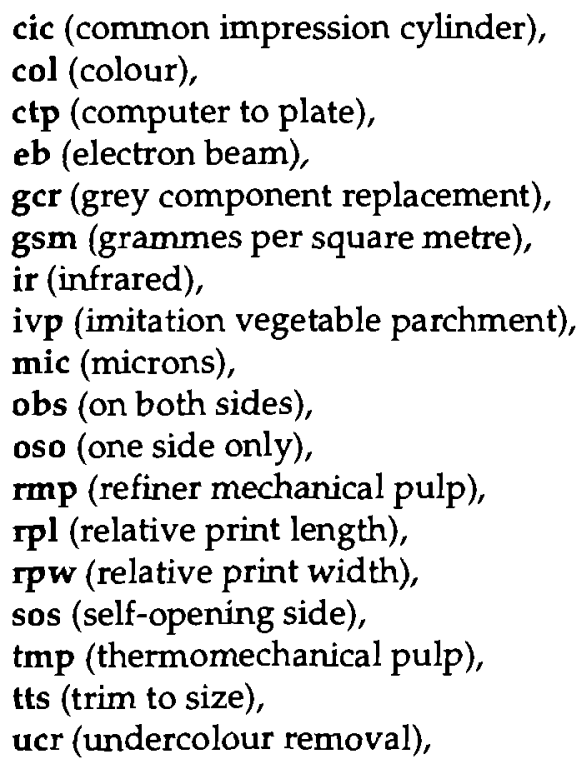

Daar word terdeë besef dat alle nuwe terme wat gedurende die afgelope paar jaar in gebruik gekom het, nie ingesluit kon word nie. Die vraag ontstaan 
egter nou: Wat word gedoen in 'n geval waar daar nog nie ' $n$ Afrikaanse ekwivalent bestaan nie? Word die gebruik van neologismes aangemoedig?

Dit is voor die hand liggend dat die metode wat gebruik is om die boek te bind, bedoel is om koste te besnoei. Na die eerste paar keer van gebruik is egter gevind dat die bladsye uitmekaar val. Gevolglik is die boek nie baie duursaam nie. Wat wél belangrik is, is dat dit 'n baie negatiewe indruk skep van die spesifieke vakgebied.

Drie ooglopende foute word in hierdie verband bespeur:

- Skutblaaie is afwesig. Skutblaaie sou ten minste verhoed het dat die omslag van die teks sou wegskeur.

- Die verdiepwerk op die boekrug is nie diep genoeg nie. Dit verhoed dat die kleefmiddel 'n goeie greep op die boekrug kry.

- Die grein van die papier loop in die verkeerde rigting (dwarsvesel in plaas van langsvesel). Dit is ' $n$ absolute voorvereiste vir enige lymgebinde boek. Indien hierdie gebruik nie geïmplementeer word nie, veroorsaak dit dat die omslag en die teks van mekaar af wegtrek by die lymgebinde boekrug.

' $n$ Beter kwaliteit produk sou die inhoud van die boek véél meer aansien besorg het. Omdat die gehalte swak is, negeer dit tot 'n mate die moeite en inspanning wat met die opstel daarvan gepaard gegaan het.

Alhoewel daar vir alle Engelse terme Afrikaanse ekwivalente voorsien is, is daar wel terme gevind wat nie in die publikasie verskyn nie. Weereens is die volgende lys geensins volledig nie, maar dit is wel Engelse terme waarvoor al in die verlede Afrikaanse ekwivalente gesoek is:

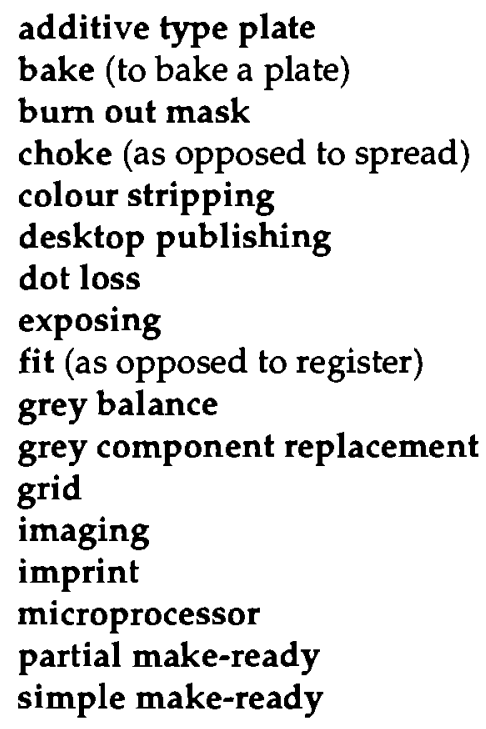


spread (as opposed to choke)

subtractive type plate

trapping

up (as in 8 up, 16 up, etc.)

Die vertaling van die volgende terme skep ook verwarring en daar behoort uitsluitsel hieroor gekry te word:

hue: tint, skakering

shade: skakering

tint: tint

In die breë gesien, is hierdie publikasie 'n baie nuttige stuk werk wat ' $n$ definitiewe leemte in die bedryf vervul. Dit is belangrik dat die teks op datum gehou word om erkenning te gee aan die betekenisvolle bydrae wat die outeurs op hierdie vakgebied gelewer het.

\title{
Bibliografie
}

Odendal, F.F. (Hoofred.). 1994. HAT: Verklarende Handwoordeboek van die Afrikaanse Taal. Midrand: Perskor.

Wijnekus, F.J.M. (Red.). 1983. Elsevier's Dictionary of the Printing and Allied Industries. Amsterdam: Elsevier.

Terblanche, H.J. 1985. Engels-Afrikaanse Tegniese Woordeboek. Goodwood: Nasou.

\author{
Nolan N. Kearns \\ Protea Kollege \\ Bellville \\ Republiek van Suid-Afrika
}


P.R. Subramanian (Chief Editor). Kriyāoin Tarkālat Tamil Akarāti (TamilTamil-Ankilam) (Dictionary of Contemporary Tamil (Tamil-Tamil-English)), 1992, reprint 1997, xxxvi +980 pp. ISBN 81-85602-57-3. Chennai: Cre-A Publishers. E-mail: crea@vsnl. com. Price Rs. 270,00.

In the informative introduction the compilers highlight the reasons for compiling a dictionary of present-day Tamil. Over the years changes have taken place in the Tamil language (words and meanings). These changes, occurring speedily and constantly, have caused a difference between the spoken and written languages, necessitating such a dictionary. Hindu, Islamic and Christian traditional usage of Tamil words has been considered, taking into account that grammatical rules were not ignored.

\section{Structure}

This dictionary is well structured:

- The headword is in bold print and this is followed by the part of speech e.g. noun, verb, adverb or adjective.

- Words are numbered to bring out different senses.

- Information about form change e.g. with regard to verbs, besides the root verbs, verbal participles, are also given.

- Two words that are commonly used with slight changes in form and meaning are only given once and for the second word the user is referred to the meaning given for the first word.

- Immediately after the required Tamil word the meaning or definition of this word is given in Tamil before the English meaning is given.

- With abstract nouns the termination particles for the formation of adverbs and adjectives are given.

- Words commonly used in Sri Lankan Tamil are stipulated.

- Words are used in sentences for greater clarity.

An adequate list of abbreviations used in the dictionary is included.

\section{Explanatory Notes}

Useful explanatory notes are given to assist the user. These include the explanation of grammatical information or terms given with the headwords.

Other explanatory notes include those on:

- the reason for numbering certain words,

- word changes, 
- the variety of word usage e.g. honorific and ordinary forms, words unique to particular communities, to particular regions or countries, or to particular religions,

- the different ways in which meanings may be given in Tamil including the numbering of the different meanings of one word,

- the English meaning,

- the pronunciation of the initial letters of certain Tamilisised Sanskrit words (given in English within brackets), and

- the purpose of sentence examples and pictures.

\section{Unique Features}

This is the first Tamil dictionary to give sentences and/or phrases to assist the user to understand the words better. Obsolete words and many words from ancient Tamil literature are omitted.

This is also the first dictionary giving modern changes in the Tamil language with regard to new words and meanings are concerned. According to Tamil grammar, all the letters of the Tamil alphabet cannot be used as initial letters in words, i.e. certain phonemes will never appear at the beginning of words. However, since this dictionary caters for words used in modern Tamil, foreign words now commonly used in speech and writing have been included. This has resulted in the occurrence of initial sounds or letters beyond the normally accepted usage.

According to the authors this is the first Indian language dictionary to be compiled using a computer.

\section{Assessment}

This is a comprehensive dictionary which contains 15875 words and 23883 sentences or phrases. It deals with both simple and compound words. This being a contemporary dictionary, the authors have concentrated on words that are commonly used in present-day Tamil, i.e. words used by present-day speakers and by modern writers in novels, readers, magazines etc. Foreign words and newly "coined" words that form part of the present-day vocabulary are included. However, the spelling of foreign words creates slight distortions in pronunciation. Rare words or many words from ancient Tamil literature that are no longer in use and that are included in all other dictionaries, have been removed from this dictionary.

Among the foreign words in this dictionary are a large number of English words that form part of the vocabulary of the present-day Tamils in India. A few examples of words that use sounds or letters that are not used as initial letters according to Tamil grammar are: tumblex, dozen, doctor, dollar, tin, tea, teacher, dupe, rail, rickshaw, ration, rubber, rowdy, levy, crop, club, carrier 
and gorilla. Other words include amen, hurricane, hotel, sir, chill, cell, scent, cycle (bicycle), soda, soap, note, pen and pyjamas. It is important to note that the pronunciation of these words differs slightly from the English pronunciation. This is due to the lack of correlation between the phonic sounds of Tamil and English. Another factor is the absence of certain English phonic sounds in Tamil. These English words are spelt as they are pronounced by the Tamils in India. An example is the pronunciation of dozen. Since the phonic sound $[z]$ is not found in Tamil, this word is actually spelt and pronounced in Tamil as dojen.

From an early period in the history of Tamil many Sanskrit words crept into the language. These words contain five phonic sounds that do not belong to the Tamil language. From that early period Tamil grammar allowed for substitution of these sounds. While language purists may use the grammatically converted form, many speakers in India still use these words in their original form. A large number of these original words containing these five pure Sanskrit sounds are given in this dictionary.

Words are used in lucid sentences and phrases as examples to assist the user with a clear understanding of the meaning. These sentences and phrases are fairly simple. The dictionary also contains 209 clear pictures illustrating special words. This will definitely assist the user, especially the foreign user, to gain a clearer understanding of nouns encountered for the first time. While Tamil words can convey several meanings, the compilers of this dictionary have chosen the most commonly used meanings.

This is a bilingual dictionary, and will only be useful to bilingual speakers who can read the Tamil script. As transliterations are not given, it will serve no purpose to people wishing to learn Tamil without learning the Tamil script. However, besides in India, this dictionary is invaluable in countries such as South Africa where Tamil is used in speaking, reading and writing.

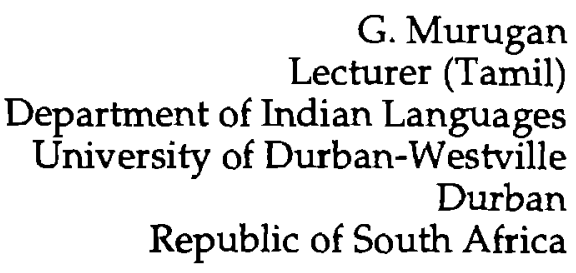


P.R. Subramanian (Chief Editor). Tarkālat Tamil Maraputtotar Akarāti (Tamil-Tamil-Ankilam) (Dictionary of Idioms and Phrases in Contemporary Tamil (Tamil-Tamil-English)), 1997, xliii + 404 pp. ISBN 81-900694-0-3. Chennai: Mozhi. E-mail: mohzi@ md3.vsnl.net.in. Price Rs. 200,00.

This is a publication on Tamil idioms and phrases compiled to assist Tamils to make spoken and written language interesting. Contained in this dictionary are both traditional and contemporary idioms and phrases. This dictionary is essential for all researchers, Tamil lovers, scholars in linguistics and students.

\section{Main Components}

\section{Introduction}

A good introduction forms part of this dictionary. This introduction

- explains the need for such a publication,

- gives the construction pattern of idioms and phrases and their limits,

- explains various types of idioms and phrases,

- explains the relationship between proverbs and idioms and phrases, and how some proverbs became idioms and phrases,

- gives the relationship between the Dictionary of Idioms and Phrases in Contemporary Tamil and the Dictionary of Contemporary Tamil, and

- gives a detailed explanation of some structural aspects of this dictionary.

\section{List of Abbreviations}

A short list of abbreviations to assist the user is included. This list is adequate for this dictionary.

\section{Structure}

The structure or arrangement of the dictionary with the key words, symbols and grammatical abbreviations applied in the dictionary is well set out to assist the user. Some aspects highlighted in the structure include:

- obvious words that may be omitted from the head idiom or phrase, given in brackets,

- the use of asterisks next to words that may be substituted, with the suitable word given in the right-hand column of the page,

- the numbering of idioms and phrases with similar meanings, 
- other forms of the head phrase given in the right-hand column of the page,

- the general rule for classifying grammatical changes in head idioms and phrases,

- the change of the grammatical form of a single word,

- the use of arrows to show the grammatical form from which the spoken form of a used word is derived,

- other phrases that may be formed from the head phrase,

- the numbering of the various meanings,

- the explanation of head idioms and phrases in Tamil within their context and the advanced meanings of head idioms and phrases,

- the explanation of the head idioms and phrases in English, the English equivalent appearing in bold print, and

the use of the symbol \# to show the use of the singular instead of the plural form, absence or inclusion of particles and the change of the form of a verb.

\section{Explanatory Notes}

Useful explanatory notes are given to assist the user. The explanatory notes are mostly a detailed explanation of the structural aspects.

\section{Assessment}

The authors have made an important contribution in preparing this outstanding collection of idioms and phrases. This is the first dictionary of contemporary Tamil idioms and phrases. The authors have analysed the characteristics of traditional and customary idioms and phrases in detail and their variation in expression and meaning. The head phrases are printed in bold type. This is followed by a Tamil explanation of the head phrase. The equivalent in English is given next to it and if the equivalent English idiom or phrase is an accepted one in the English language then it is shown in bold print.

Explanations of head idioms and phrases in English and Tamil are lucid. Popular English idioms and phrases which were at one time part of the syllabus in schools make this publication very interesting, especially to bilingual speakers. They should derive pleasure in using these during conversations with other bilingual speakers. These are given in bold print.

This publication consists of 1930 head idioms and phrases. These idioms and phrases have been used in suitable sentences to assist the user to understand them. The over 5000 sentences used as examples have been carefully chosen. The various examples given are very suitable and excite the interest in the users. Further explanations of head phrases are given within brackets. 
The absence of grammar with regard to traditional idioms and phrases will greatly interest common readers. It is important to note, however, that grammar is not totally ignored.

New idioms and phrases which are not traditional or customary are also included and well explained. Furthermore the choice of idioms and phrases seems to be from different regions or areas of South India. The authors have taken great pains in giving detailed explanations. In their explanations they have brought out the intricacies of idioms and phrases with meanings based on area or, region.

The equivalent English idioms and phrases will also benefit non-Tamils. It is important to note that all idioms and phrases given in English are not wordfor-word translations of the Tamil head phrases. Instead the authors have chosen to translate the phrase or idiom as a whole. A word-for-word translation could distort the meaning. The following are a few examples of popular English idioms and phrases included in this dictionary:

bite off more than one can chew, dog tired, once in a blue moon, old wives' tale, build castles in the air, God knows, have a foot in both camps, the grass is greener on the other side of the hill, give someone an inch and he will take a mile, go in one ear and out the other, kick up a dust, with open arms, twiddle one's thumb, bite the hand that feeds one, keep up with the Joneses, add fuel to the flames, like water off a duck's back, like cat and dog, I will eat my hat, by hook or by crook, kill two birds with one stone, put the squeeze on, a drop in the ocean.

The layout of this publication is very good. This is a result of the fact that it was prepared on computer. Furthermore, it is stated that the compilers spent six years in preparing this dictionary of idioms and phrases.

This publication will mainly benefit people who can read the Tamil script because the authors have chosen not to give transliterations. This dictionary will be appreciated in all countries where Tamil is taught in schools and universities. Traditional and customary idioms or phrases are from the different regions or areas within India. It is possible that Tamils who have settled in South Africa, Fiji, Réunion, Ceylon, Australia and other countries may have idioms or phrases unique to their countries. Perhaps these could also be included in the next edition. 
Frans van Niekerk, Joey Basson en Kobus Grobler (Samestellers). Wilde Woordeboek. 1997. 55 pp. ISBN 079932356 X. Pretoria: J.P. van der Walt. E-pos: jpvdwalt@iafrica.com. Prys R19,95.

Om die Wilde Woordeboek van die Hoërskool Richardsbaai aan leksikografiese beginsels te wil toets, sou (ten onregte) wees soos om 'n kaskar met 'n Formule 1 te vergelyk. Soos die opstellers dit immers self stel: "Die ... nuutskeppinge is nie eintlik bedoel om getoets te word ... deur ... ernstige woordeboekmakers nie."

Die vraag ontstaan onmiddellik of die nuutskeppinge wel bestaanbare nuutskeppinge kan wees as hulle in die meeste gevalle buite konteks ondeursigtig is tot op die punt van onverstaanbaarheid. Byvoorbeeld: Wie sou raai dat 'n uitskietpinkie die ekwivalent is van die Engelse "dandy" in 'n sin soos: $\mathrm{Hy}$ is ' $n$ uitskietpinkie? Of: Piet is ' $n$ kers by Eskom (' $n$ "outsider")? Desnieteenstaande beskaam die hoop nie die opstellers dat die soms vindingryke, soms "slim" skeppings so gebruiklik sal word dat hulle aan die gebruiksbeginsel van woordeboeke sal voldoen nie.

Sonder om die eerste paragraaf van hierdie bespreking geweld aan te doen, 'n enkele opmerking oor iets wat nie net woordeboeke nie, maar ook ander woordversamelings raak waar alfabetisering ' $n$ sleutelrol by ontsluiting speel: Die Wilde Woordeboek het klaarblyklik nie onder die waaksame oog van groter woordeboekbroers deurgeloop nie. Die volgende inskrywings is alfabeties op die verkeerde plek: draw, hangover, rondshunt (onder S opgeneem), skip (behoort voor ski pants te kom), treat, trim, toyi-toyi, werkskepper. Verder is inwoner van Gauteng en inwoner van KwaZulu-Natal onder $G$ en $K$ onderskeidelik opgeneem (verstrooi soos in die diaspora?).

Die Wilde Woordeboek bied 'n uurtiie se aangename vermaak as ' $n$ mens na vondste soek. Die inskrywings se reikwydte en trefkrag is waarskynlik beperk tot hoogstens groeptaalsprekers - miskien op hoërskoolvlak.

\author{
A.F. Prinsloo \\ Taaladviseur \\ Radiosondergrense \\ Aucklandpark \\ Johannesburg \\ Republiek van Suid-Afrika
}


Dictionary of Grammar, 1994, reprint 1995, 256 pp. ISBN 1854717022. London: Claremont Books. Price 99p.

This dictionary, like the other volumes in the Pocket Reference Library series, has a wide target audience in mind. The blurb on the back cover immodestly describes it as "invaluable for all writers of English". The other claim is more realistic: the dictionary is indeed, as the cover suggests, "simple and easy to use". Its format allows it to deal with specific aspects of grammar as well as broad categories in alphabetical arrangement, and there is generally good cross-referencing. For instance, one can start at noun and find references to sub-categories, or at a sub-category such as mass noun, where one will be referred to uncountable noun, the alternative term. On the whole the entries are succinct and in plain English.

In what follows, a few entries are used to comment in more detail on the merits (as well as weak points) of the dictionary. The first entry to be discussed is the one on abbreviations. It reads as follows:

abbreviations are shortened forms of words usually used as a space-saving technique and becomingly increasingly common in modern usage. They cause problems with regard to punctuation. The common question asked is whether the letters of an abbreviation should be separated by full stops. In modern usage the tendency is to omit full stops from abbreviations. This is most true of abbreviations involving initial capital letters, as in TUC, BBC, EEC and USA. In such cases full stops should definitely not be used if one or some of the initial letters do not belong to a full word. Thus television is abbreviated to TV and educationally subnormal to ESN.

There are usually no full stops in abbreviations involving the first and last letters of a word (contractions) $\mathrm{Dr}, \mathrm{Mr}, \mathrm{Rd}, \mathrm{St}$, but this is a matter of taste.

Abbreviations involving the first few letters of a word, as in 'Prof' (Professor) are the most likely to have full stops, as in 'Feb.' (February) but again this is now a matter of taste.

These are mostly formed by adding lower-case s, as in Drs, JPs, TVs. Note the absence of apostrophes. See also ACRONYMS.

As can be seen, simple, clear guidelines are given. But the approach is not prescriptive: words like "tendency" and the reference to "a matter of taste" in discussing whether contractions should have a full stop or not, acknowledge that there are different practices.

Another aspect which makes it easy to use, is that the entries are discursive. The style adopted is interactive taking account of the readers' likely needs. As we can see illustrated in this entry, questions which are likely to come from users and/or necessary explanations sought by them are skilfully 
woven into the text. In this entry, assumed questions seem to be why abbreviations are increasingly being used and how abbreviations should be punctuated. Advice is economically offered.

The fact that the abbreviations given are mainly drawn from Europe should not present a problem: the principles emerge clearly.

Another aspect which is helpful to the user is that a distinctive category, such as short forms, is dealt with in a separate paragraph. A later entry acronyms defines the differences between acronyms and abbreviations as the crossreferencing usefully points out.

One deficiency is that certain aspects, such as how to write and punctuate the abbreviations of university degrees and initials of personal names, are not addressed in the entry. There is also a serious printing error that the proofreader did not detect. In the final paragraph, "These" should be replaced by "Plurals" for the sentence to make sense.

We turn to another entry. to explore the usefulness of the definitions of grammatical terms that are offered. Most of the items are effectively described and are well-illustrated by means of examples. However, some crucial entries are not very valuable. Let us consider the case of number agreement or concord:

number agreement or concord refers to the fact that grammatical units should agree in terms of number. Thus a singular subject is followed by a singular verb, as in 'The girl likes flowers', 'He hates work' and 'She was carrying a suitcase'. Similarly a plural subject should be followed by a plural verb, as in 'They have many problems', 'The men work hard' and 'The girls are training hard'.

This very basic discussion of an aspect which is notoriously problematic will not offer much help. It ignores common problems such as whether to use a singular or plural verb with a number (a number of people was/were there) or the considerations which determine whether collective (group) nouns like government should be followed by a singular or plural verb. The clearer and more usefully detailed accounts provided by Weiner (1983) and Leech and Svartvik (1994) give a more useful overview of this complex area.

By contrast, the entry on adverbs is rather detailed. It gives more categories than the comprehensive Communicative Grammar of English (Leech and Svartvik 1994), and seems to focus on information rather than matters of use or usage. Although the entry (if one includes that on adverbial clauses) stretches over 6 pages, it pays no attention to practical problems such as the order in which adverbs are used in sentences.

On occasion, the information given is inaccurate. Complement is described as being "the equivalent of an 'object' in a clause with a copula or linking verb". Here it would also have been useful to have a cross-reference to linking verb. Even if that had been done, however, the two paragraphs would 
still not provide a clear definition of complement. A further instance of ambiguity or confusion in the use of terms can be seen in the unmarked overlap between the entries for multi-sentence, complex sentence and compound sentence. This is another instance where cross-referencing would have been useful.

Another criticism is that examples are not always given to illustrate points made. The entry under split infinitive, for example, would have benefited greatly from an illustration of the kind of clumsy sentence that could result from "slavish adherence to the rule". Unlike Weiner (1983), this dictionary does not point out that an infinitive should be split on occasion to avoid ambiguity. It does, however, point out that split infinitives are increasingly a feature of modern usage.

One final carp: there are entries on rather obscure items such as meiosis and zeugma.

meiosis is a figure of speech using understatement to emphasize the size or importance of something, as in 'He's a decent enough bloke' and 'He's a rather decent tennis player'.

zeugma is a figure of speech which uses a single word to apply to two words which are not appropriate to each other, as in 'We collected our coats and our baby', 'She left the building and her job', and 'She left in a taxi and a fit of hysterics'. Zeugma is similar to BATHOS.

The better aspects of the dictionary deserve some attention. The sections on punctuation, for example, are generally good. The advice given is practical and relevant, reflecting a dynamic view of language use. The entry on the apostrophe can stand for the others.

apostrophe $\mathrm{e}^{2}$ is a form of punctuation that is mainly used to indicate possession. Many spelling errors centre on the position of the apostrophe in relation to s.

Possessive nouns are usually formed by adding 's to the singular noun, as in 'the girl's mother', and 'Peter's car'; by adding an apostrophe to plural nouns that end in $s$, as in 'all the teachers' cars'; by adding 's to irregular plural nouns that do not end in $s$, as in 'women's shoes'.

In the possessive form of a name or singular noun that ends in $s, x$ or $z$, the apostrophe may or may not be followed by s. In words of one syllable the final $s$ is usually added, as in 'James's house', 'the fox's lair', 'Roz's dress'. The final $s$ is most frequently omitted in names, particularly in names of three or more syllables, as in 'Euripides' plays'. In many cases the presence or absence of final $s$ is a matter of convention.

The apostrophe is also used to indicate omitted letters in contracted forms of words, as in 'can't' and 'you've'. They are sometimes used to 
indicate missing century numbers in dates, as in 'the ' $60 \mathrm{~s}$ and '70s', but are not used at the end of decades, etc, as in '1960s', not '1960's'.

Generally apostrophes are no longer used to indicate omitted letters in shortened forms that are in common use, as in 'phone' and 'flu'.

Apostrophes are often omitted wrongly in modern usage, particularly in the media and by advertisers, as in 'womens hairdressers', 'childrens helpings'. In addition, apostrophes are frequently added erroneously (as in 'Potato's for sale' and 'Beware of the dog's'). This is partly because people are unsure about when and when not to use them and partly because of a modern tendency to punctuate as little as possible.

Here the general tendency to use less punctuation is clearly explained, with useful insights into the way the media and the use of computers has affected usage.

The merits of the dictionary (given its purpose) far outweigh its deficiencies. However, some skilful editing and adaptation could bring it far closer to deserving the publisher's claim that it is "invaluable for all writers".

\title{
References
}

Leech, G. and J. Svartvik. 1994. A Communicative Grammar of English. London: Longman. Weiner, E.S.C. 1983. The Oxford Guide to English Usage. Oxford: Oxford University Press.

\author{
E. Ridge \\ Division of English \\ Department of Didactics \\ University of Stellenbosch \\ Stellenbosch \\ Republic of South Africa
}


T. McArthur and I. Kernerman (Editors). Lexicography in Asia. 1998, 190 pp. ISBN 965-90207-0-8. Tel Aviv: Password Publications. E-mail: pass@ password.co.il. Price US $\$ 29,50$.

\section{Introduction}

Reinhard Hartmann cautions in the Postscript against the incorrect notion "that lexicography is a uniform discipline with a Eurocentric base". He refers to the "venerable cultural traditions" of Asia, and draws attention to the vitality and diversity of lexicography in Asia. In view of this richness and diversity, coeditor Ilan Kernerman adds in the Preface that "the present selection is far from encompassing the vast potential implied by its name, and a great many related linguistic, geographical and historical aspects are not represented". The foregoing indicates the vast areas to be covered as well as the promising potential of developing Asian lexicography in all its facets, which in turn would enrich lexicography globally.

\section{The Contents of Lexicography in Asia}

This publication contains selected scholarly papers on Asian lexicography mostly presented at conferences and symposiums. Nine of the papers were read at the Dictionaries in Asia Conference, Hong Kong University of Science and Technology, 26-29 March 1997, and two papers were presented at the Language Study and the Thesaurus in the World Symposium, National Language Research Institute, Tokyo, 29 August 1997. One paper, by Shigeru Yamada and Yuri Komuro, was published in Kernerman Dictionary News (No. 6, July 1998, Tel Aviv: Password). Co-editor Tom McArthur wrote an illuminating Introduction.

In the Introduction "Asian Lexicography: Past, Present and Prospective" McArthur, who attended both the Hong Kong conference (alphabetic lexicography) and the Tokyo symposium (thematic lexicography), emphasises the value of these gatherings for successfully bringing together lexicographers from all parts of Asia, even though they may be few in number. He refers to the culture, history and geography of Asia, as well as the omnipresence of English, in order to decide on a name for the book. English flourishes in various capacities in Asia. Nevertheless, Bahasa Indonesia, Hindi, Sanskrit, Persian, Malay, Arabic, Classical Chinese and Mandarin Chinese do have their regional and national roles to play. While accepting the description Lexicography in Asia as the most useful, McArthur expresses the hope that lexicography would be embraced by all scholars as a global endeavour, placing it in a "geographically wider and chronologically deeper frame of reference".

In the first paper, "Traditionality and Creativity in Lexicography", Lu Gusun of the People's Republic of Chira characterises lexicography as hard, 
empirical work, very different from the theoretical nature of linguistics. He elaborates this view by referring to lexicography as "microcosmic drudgery", which is not conducive or receptive to "theorising". He further states that computers are not yet able to dispense with the human element in lexicography - editors who do the abstract work must still lead the project of dictionary making. Gusun furthermore reflects on occasions for creativity in the field of lexicography in a move away from the traditionally conservative nature of the art, particularly with the evolution of neologisms. He avers that these neologisms are often noticed by people from afar - via "alien sensitivity". He describes traditionality and creativity as complementary factors in the making of a lexicographer.

Sangsup Lee of Korea describes the Korean dictionary in the next paper, "Corpus Linguistics and Dictionary Making in Korea". The Yonsei Corpus of Contemporary Korean, a project for the development of a "usable" dictionary of Korean, was started by Lee at Yonsei University. A corpus of three million words was developed. A survey of the reading habits of Koreans and the frequency of a university library's lending of individual books was carried out. In this way the Yonsei Corpus was able to collect much new information on the Korean language. When the Yonsei Corpus reached 30 million words in 1993, a monolingual learner's dictionary of contemporary Korean was started. Whilst this is a long-term project, smaller dictionaries and other tools for language information have been produced. Bilingual dictionaries have long been known to Koreans. Monolingual dictionaries which would serve a purpose different from the "Linguistic matchmaking" of the bilingual versions, began to emerge in the 19th century. A learner's monolingual dictionary for learning a living language would assist 5 million Koreans living abroad as well as foreigners and 70 million in Korea.

In the next paper, Arvind Kumar of India expounds "The Societal Contexts of Sanskrit, English and Hindi Thesauruses, and the Multilingual Possibilities of the Computer Age". Kumar notes that the first thesaurus was the Vedic Nighantu - a glossary of Vedic Sanskrit words listed by subject. The much later (circa 6-7 century) Amar Kosh (8 000 words) achieved fame as a thesaurus soon after its composition. Roget (of Roget's Thesaurus) acknowledges it in his introduction. The Amar Kosh is organized according to subject. It consists of three cantos altogether. The title of the first chapter of each canto indicates the subject matter, e.g. in canto 1 Heaven is followed by Sky, Directions, Time, etc. When Kumar and his wife Kusum embarked on a Hindi thesaurus (the Samantar Kosh), following Roget's Thesaurus, they realised that differences in religio-cultural beliefs and concepts would create problems of classification. The Amar Kosh was outdated in the changed historical-social contexts. This necessitated the adoption of an original method whereby one idea would lead to the next by association or juxtaposition. Already having started on a bilingual Hindi-English thesaurus, Kumar proposes the exciting concept of a "world 
thesaurus". With the increasing capacity of computers, he sees infinite possibilities in this area.

Li Lan of the People's Republic of China analyses the results of a questionnaire and translation test at a science and technology university in his paper "Dictionaries and their Users at Chinese Universities: With Special Reference to ESP Learners". Users' opinions and their interactions with dictionaries are assessed in the scope of contrastive linguistics between English and Chinese. Lan reports that Chinese dictionary training is integrated into the learning process in China. However, the same is not true for English-Chinese bilingual dictionaries. Lan believes that it would be useful if the skills learned for the use of the monolingual Chinese dictionary could be applied to the use of monolingual and bilingual English dictionaries. Lan's research (questionnaire and test) showed high levels of dictionary ownership - English-Chinese bilingual dictionaries being in the lead with every student owning one. The survey showed that the 801 respondents used a dictionary 15,28 times on average per month. Students majoring in international business used the dictionary most frequently. Looking up meanings, spelling, pronunciation and etymology are the reasons for consulting a dictionary. Chinese students have no difficulty in locating the words in the dictionary: their problem is determining the correct meaning from the many meanings provided. Lan therefore proposes that dictionaries for ESP learners should be tools for language learning and language databases.

Jacqueline Lam Kam-mei of Hong Kong presented the next paper "A Corpus-Based Subject-Specific Glossary for Computer Science Related Texts". It deals with semi-technical vocabulary in Computer Science together with the problems this causes for ESP learners, concluding with the view that a glossary of semi-technical vocabulary is more effective for understanding Computer Science related literature than a conventional dictionary. Kam-mei uses the terminology "semi-technical" to characterise words that are sometimes general, sometimes technical in meaning, depending on the context. An experiment was carried out with 120 students of Hong Kong University of Science and Technology to determine whether the use of metaphor, linguistic variation in the form of lexical modification and the manipulation of verbal humour and informality affected the comprehension of Computer Science texts (in English amongst students of a predominantly Chinese-speaking background). The tests demonstrated that "semi-technical" vocabulary is semantically distinct from the same vocabulary when it appears in general texts. A shortcoming in this respect, with regard to a growing field, is the lack of English dictionaries designed for this purpose. She therefore advocates the compiling of glossaries to aid students.

In "Interacting with the Users: Research Findings in EFL Dictionary User Studies", Yukio Tono of Japan throws light on dictionary use, particularly in respect of L2 lexicography. With the spread of English learning and teaching, a much needed shift in approach on the part of dictionary publishers was per- 
ceived - from the publisher's to the user's perspective of dictionary use. There is much competition in the large Japanese market for EFL dictionaries. However, these dictionaries do not serve the purpose of the users and there is need to restructure dictionaries on the basis of empirical data elicited from users. Tono discusses the research in dictionary user studies, viz. needs and skills analysis, dictionary use and performance in speaking, listening, reading and writing, teaching dictionary skills, etc. Tono advises that more empirical studies of dictionary use is required. Sharing of information among researchers, through websites etc., is encouraged.

The next paper takes us to another globally important East Asian language - Malay. Noor Ida Ramli expresses her thoughts "Towards an Active Dictionary for Writing Academic Essays" (on Economics). Ramli is of the view that there is no "universal" dictionary, and that a dictionary for Malay students capable of assisting them with writing essays in economics is now necessary. Students' essays were examined to identify their difficulties in writing. Students revealed difficulties with linguistic aspects viz. grammar, vocabulary, spelling, idiomatic expressions, etc. Finally students were not satisfied with existing reference works, including guidelines and models indicating what is expected from students.

Soekemi, the writer of the next paper, "Indonesian Dictionaries and How Students Use Them", informs us that the Indonesian national language Bahasa Indonesia - is gradually taking the lead, displacing the first language of speakers of Javanese, Balinese, Ambonese, etc. (450 languages amongst 200 million Indonesians). English is a foreign language taught in most schools. Dictionaries written in Indonesia in the colonial period were bilingual or multilingual, compiled by foreigners. The tremendous activity in promoting the national Indonesian language after 1945 saw the emergence of dictionaries amongst other forms of literature. General monolingual and bilingual Indonesian dictionaries have been written, including some in the USA, Russia and China. The monolingual dictionary KBBI (Kamus Besar Bahasa Indonesia) with 62000 entries, was published in 1988. It is considered a standard dictionary in Indonesia. There is only one bilingualised dictionary in Indonesia, the Password English Dictionary for Speakers of Bahasa Indonesia (PEDSBI), which, published in 1993, has not yet reached the majority of students and teachers. He concludes that since a bilingualised dictionary is an effective means of vocabulary building, various types of bilingualised dictionaries should be published for English learners at different levels.

The next paper by Ahmad Taherian of Iran discusses "Lexicography and Lexicomputing in the Persian Language". Whilst lexicomputing and computational text processing has been in progress in the Persian (Farsi) language for 25 years, a plan for compiling a dictionary for the Persian language using the latest electronic methods is now being implemented. A database of Persian words is already available and is being used to create new words and equivalents for borrowed words. This is to be found in the Farsi Linguistic Database 
(FLDB). Another important resource is the Lexicon of Linguistics. The dictionary of the Persian language is an ambitious project, and will include Persian texts since the 7th century. The FLDB will be used for this process. All varieties of the language and all dictionaries written hitherto will be put into the database. A general dictionary of the Persian language would be produced, suitable for use by people with at least secondary education.

Shigeru Yamada and Yuri Komuro of Japan were responsible for the paper "English Lexicography in Japan: Its History, Innovations, and Impact". Japan is a leading country in the field of lexicography and has contributed to the world's output of bilingual lexicography. In 1862 the first English-Japanese dictionary saw light. Then in 1915 Saito's Idiomological English-Japanese Dictionary for Japanese students was published. It laid emphasis on idiomatic expressions and provided notes on difficult points. Many other major dictionaries were published in Japan. However, it was in 1942 that Kaitakusha published the Idiomatic and Syntactic English Dictionary, compiled by Hornby, Gatenby and Wakefield in Japan. The English-Japanese Learner's Dictionaries (EJLD) contain detailed information of use to Japanese learners. Some innovations such as the indication of frequent or important words, usage notes, verb patterns etc. enhance the value of the EJLDs.

Co-editor Ilan Kernerman's paper is titled "New Dictionary Needs of Young Learners of English in Asia". Previous papers have already given some indications of needs in Japan, Indonesia, and Malaysia. Kernerman's sights are on a printed dictionary suitable to our age and its target group of users. Dictionaries shall not remain passive reference books, but must become potentially active learning tools.

The last paper included in this publication, "A Radical Change of Direction: English Lexicography in the Fifteenth Century", was presented by Reiko Takeda of Japan. Apart from the fact that the early English dictionaries were valuable forerunners of the modern dictionaries, the paper does not add much to the theme of lexicography in Asia.

\section{Conclusion/Recommendation}

The learned, insightful and informative papers constituting this publication are of interest to any language teacher and lexicographer. The editors are language teachers and lexicographers of considerable experience and have rendered a service to their colleagues with their publication. Asia is a vast continent, even if one ignores the Russian part. Its varieties of languages, orthographies, cultures and socio-political life styles are reflected through their literary outputs in their own languages. Moreover, their interaction with the global community has to be through the medium of English. The papers in this compilation reflect some of their concerns and achievements, and point towards the greater tasks ahead. Much can be imbibed by other regions of the world from the Asian experiences. 
Whilst I am certain that this publication would appeal to any serious language teacher (at least at tertiary level), it is most certainly an invaluable addition to the lexicologist's or lexicographer's library.

Rambhajun Sitaram

Centre for Languages

University of Durban-Westville

Durban

Republic of South Africa 


\section{Publikasieaankondigings / Publication Announcements}

Dictionary of Grammar, 1994, reprint 1995, 256 pp. ISBN 185471702 2. London: Claremont Books. Price 99p. (Review in this issue)

Joyce M. Hawkins (Compiler). The South African Oxford School Dictionary, 1996, xxi + 551 pp. ISBN 019571414 8. Cape Town: Oxford University Press. Email: oxford@oup.co.za. Price R44,95. (Review in this issue)

T. McArthur and I. Kernerman (Editors). Lexicography in Asia. 1998, 190 pp. ISBN 965-90207-0-8. Tel Aviv: Password Publications. E-mail: pass@ password.co.il. Price US $\$ 29,50$. (Review in this issue)

Microsoft Encarta 99 Encyclopedia - World English Edition, 1998. Microsoft Corporation. URL: http://microsoft.com/southafrica/contact/email.asp. Price $\pm R 280$ (Standard edition) $/ \pm R 510$ (Deluxe edition) (Review article in this issue)

Nasionale Terminologiediens van die Departement van Kuns, Kultuur, Wetenskap en Tegnologie. Drukkerswoordeboek / Printing Dictionary, AfrikaansEnglish / English-Afrikaans, hersiene uitgawe, 1995, xviii + 309 pp. ISBN 0621-17323-1. E-pos: asteyn@print.pwv.gov.za. Pretoria: Staatsdrukker. Prys R20,20. (Resensie in dié uitgawe)

A.F. Prinsloo. Afrikaanse Spreekwoorde en Uitdrukkings met Engelse Ekwivalente en 'n Omvattende Tweetalige Indeks, 23ste uitgawe 1997, 358 pp. ISBN 0627 02229 4. E-pos: jlvschai@jlvanschaik.com. Pretoria: J.L. van Schaik. Prys R79,95. (Resensieartikel in dié uitgawe)

P.R. Subramanian (Chief Editor). Kriyāvin Tarkälat Tamil Akaräti (Tamil-TamilAnkilam) (Dictionary of Contemporary Tamil (Tamil-Tamil-English)), 1992, reprint 1997, xxxvi + 980 pp. ISBN 81-85602-57-3. Chennai: Cre-A Publishers. E-mail: crea@md3.vsnl.com. Price Rs. 270,00. (Review in this issue)

P.R. Subramanian (Chief Editor). Tarkalat Tamil Maraputtotar Akaräti (TamilTamil-Ankilam) (Dictionary of Idioms and Phrases in Contemporary Tamil (Tamil-Tamil-English)), 1997, xliii + 404 pp. ISBN 81-900694-0-3. Chennai: Mozhi. E-mail: mohzi@md3.vsnl.net.in. Price Rs. 200,00. (Review in this issue) 
K.H. van Dalen-Oskam, K.A.C. Depuydt, W.J.J. Pijnenburg and T.H. Schoonheim (Editors). Dictionaries of Medieval Germanic Languages: A Survey of Current Lexicographical Projects. Selected Proceedings of the International Medieval Congress, University of Leeds, 4-7 July 1994. 1997, viii + 197 pp. ISBN 2-503-50601-1. Turnhout: Brepols. E-mail: publishers@brepols.com. Price Belgian $f 1613$.

Frans van Niekerk, Joey Basson en Kobus Grobler (Samestellers). Wilde Woordeboek. 1997, 55 pp. ISBN 079932356 X. Pretoria: J.P. van der Walt. Epos: jpvdwalt@iafrica.com. Prys R19,95. (Resensie in dié uitgawe) 


\section{VOORSKRIFTE AAN SKRYWERS}

(Tree asseblief met die Buro van die WAT in verbinding vir 'n uitvoeriger weergawe van hierdie instruksies, of besoek ons webblad: http://www.sun.ac.za/wat/index.htm)

\section{A. REDAKSIONELE BELEID}

1. Aard en inhoud van artikels

Artikels kan handel oor die suiwer leksikografie of oor implikasies wat aanverwante terreine, bv. linguistiek, algemene talwetenskap, rekenaarwetenskap en bestuurskunde vir die leksikografie het.

Bydraes kan onder enigeen van die volgende rubrieke geklassifiseer word:

(1) Navorsingsartikels: Grondige oorspronklike wetensknplike navorsing wat gedoen en die resulcate wat verkry is.

(2) Beskouende artikels: Bestaande navorsingsresuleate en ander feite wat op 'n aarspronklike wyse oorsigtelik, interpreterend, vergelykend of krities evaluerend aangebied word.

(3) Resensieartikels: Navorsingsarikels wat in die vorm van 'n kritiese resensie van een of meer gepubliseerde wetenskaplike bronne aangebied word.

Bydraes in kategoriez (1)-(3) word aan streng anonieme keuring deur onathanklike akaderriese vakgenote onderwerp ten einde die intemasionale navorsingsgehalte daarvan te verseker.

(4) Resensies. 'n Ontleding en kritiese evaluering van gepubliseerde wetenskaplike bronne en produkte, soos boeke en rekenaarprogramme.

(5) Projekte. Besprekings van leksikografiese projekte.

(6) Leksikovaria. Enigeen van 'n groot verskeidenheid arikels, aankondigings, praktykgerigte inligting en nuusvrystellings van leksikografiese verenigings wat veral vir die praktiserende leksikograaf van waarde sal wees.

(7) Verslae. Verslae van konferensies en werksessies.

Bydraes in kategoried (4)-(7) mot almal aan die eise van akademiese geskrifte voldoen en word met die oog hierop deur die redaksie gekeur.

\section{Wetenskaplike standaard en keuringsprosedure}

Lexikos is deur die Departement van Onderwys van die Suid-Afrikaanse Regering as 'n gesubsidieerde d.w.s. inkomstegenererende navorsingstydskrif goedgekeur.

Artikels sal op grond van die volgende aspekte beoordeel word: taal en styl; saaklikheid en verstaanbaarheid; probleemstelling, beredenering en gevolgtrekking; verwysing na die belangrikste en jongste literatuur; wesenlike bydrae tot die spesifieke vakgebied.

\section{Taal van bydraes}

Afrikans, Duits, Engels, Frans of Nederlands.

\section{Kopiereg}

Nóg die Buro van die WAT nóg die African Association for Lexicography (AFRILEX) aanvaar enige aanspreeklikheid vir eise wat wt meewerkende skrywers se gebruik van materiaal uit ander bronne mag spruit.
Outeursreg op alle materiaal wat in Lexikos gepubliseer is, berus by die Beheerraad van die Woordeboek van die Afrikaanse Taal. Dit staan skrywers egter vry om hulle materiaal elders te gebruik mits Lexikos (AFRILEX-reeks) erken word as die oorspronklike publikasiebron.

\section{Oorspronklikheid}

Slegs oorspronklike werk sal vir opname oorweeg word. Skrywers dra die volle verantwoordelikheid vir die oorspronklikheid en feitelike inhoud van hulle publikasies.

\section{Gratis cordrukke en eksemplare}

Skrywers ontvang vyf gratis cordrukke van elke navorsings. beskouende of resensieartikel van hulle wat gepubliseer is asook een gratis eksemplaar van die uitgawe waarin sodanige arikel(s) verskyn het. Skrywers van suiwer evaluerende resensies en van bydraes tot die rubrieke Leksikovaria, Projekte en Verslae ontvang vyf gratis oordrukke van hulle bydraes. In laasgenoemde vier kategoried kan die redaksie egter, athangend van die aard en ormang van die bydraes, besluit om ook 'n eksemplar van die betrokke uitgawe aan in skrywer toe te ken.

\section{Uitnodiging en redaksionele adres}

Alle belangstellende skrywers is welkom om bydraes vir opname in Lexikos te lewer en aan die volgende adres te stuur:

\section{Die Redakteur}

LEXIKOS

Buro van die WAT

Posbus 245

7599 STELIENBOSCH

Republiek van Suid-Afrika

\section{B. VOORBEREIDING VAN MANUSKRIP}

Die manuskrip van arikels moet aan die volgende redaksionele vereistes voldoen:

\section{Lengte en formant van artikels}

Bydraes moet verkjeslik nie 20 getikte A4-bladsye met teks in dubbelspasièring en ruim kantlyne (ongeveer $2.5 \mathrm{~cm}$ ) oorskry nie. Manuskrip moet verkieslik in elektroniese formaat as ASCll-teks, as volledig geformateerde Microsoft Word (DOS of Windows) leers of as WordPerfect (DOS of Windows) leers op rekenaarskyf ( $360 \mathrm{~KB}$ tot $1.44 \mathrm{MB}$ ) voorgelê word. 'n Rekenaardrukstuk van die artikel moet die skyf vergesel. Elke arikel moet voorsien wees van 'n Engelse opsomming van tussen 150 en 250 woorde, sowel as tussen 10 en 30 Engelse sleutelwoorde.

\section{Grafika}

Een stel duidelike corspronklike illustrasies, tabelle, grafieke, diagramme, of kwaliteitsafdrukke daarvan, moet voorgele word. Die plasing van grafika binne die teks moet dujdelik aangedui word

3. Bibliografiese gegewens en verwysings binne die teks Kyk na onlangse nommers van Lexikos vir meer inligting. 


\section{INSTRUCTIONS TO AUTHORS}

\section{(For a more detailed version of these instructions, please contact the Bureau of the WAT or refer to our web} page: http://www.sun.ac.zatwat/index.htm)

\section{A. EDITORIAL POLICY}

\section{Type and content of articles}

Articles may deal with pure lexicography or with the implications that related fields such as linguistics, general linguistics, computer science and management have for lexicography.

Contributions may be classified in any one of the following categories:

(1) Research articles: Fundamentally original scientific research that has been done and the results that have been obtained

(2) Contemplative articles: Reflecting existing research results and other facts in an original, synoptic, interpretative, comparative or critically evaluative manner.

(3) Review articles: Research articles presented in the form of a critical review of one or more published scientific sources.

Contributions in categories (1)-(3) are subjected to strict anonymous evaluation by independent academic peers in order to ensure the international research quality thereof.

(4) Reviews: An analysis and critical evaluation of published scientific sources and products, such as books and computer software.

(5) Projects: Discussions of lexicographical projects.

(6) Lexicovaria: Any of a large variety of articles, announcements, practice-oriented information and press releases by lexicographic societies which are of particular value to the practising lexicographer.

(7) Reports: Reports on conferences and workshops.

Contributions in categories (4)-(7) must all meet the requirements of academic writing and are evaluated by the editors with this in mind.

\section{Academic standard and evaluation procedure}

The Department of Education of the South African Go vernment has approved Lexikos as a subsidized, i.e. incomegenerating research joumal.

Articles will be evaluated on the following aspects: lang uage and style; conciseness and comprehensibility; problem formulation, reasoning and conclusion; references to the most important and most recent literature; substantial contribution to the specific discipline

\section{Language of contributions}

Afrikaans, Dutch, English, French or German.

\section{Copyright}

Neither the Bureau of the WAT nor the African Association for Lexicography (AFRILEX) accepts any responsibility for claims which may arise from contributing authors' use of material from other sources.
Copyright of all material published in Lexikos will be vested in the Board of Control of the Woordeboek van die Afrikaanse Taal. Authors are free however to use their material elsewhere provided that Lexikos (AFRILEX Series) is acknowledged as the original publication source.

\section{Originality}

Only original contributions will be considered for publication. Authors bear full responsibility for the originality and factual content of their contributions.

\section{Free offprints and copies}

Authors will receive five free offprints of each of their research, contemplative or review articles published, as well as one complimentary copy of the issue containing such article(s). Authors of purely evaluative reviews and of contributions to the categories Lexicovaria, Projects, and Reports receive five free offprints of their contributions. In the case of the latter four categories, the editors may, however, depending on the nature and scope of the contributions, decide to grant the author a copy of the issue concerned.

\section{Invitation and editorial address}

All interested authors are invited to submit contributions for publication in Lexikos to:

\section{The Editor}

LEXIKOS

Bureau of the WAT

P.O. Box 245

7599 STELLENBOSCH

Republic of South Africa

\section{B. PREPARATION OF MANUSCRIPTS}

Manuscripts of articles must meet the following editorial requirements:

\section{Length and format}

Contributions should not exceed more than 20 typewritten A4 pages with double spacing and ample margins (about $2,5 \mathrm{cms}$ ). Manuscript should preferably be in electronic form on a (360 KB to 1.44 MB) floppy disk as either ASCII text, fully-formatted Microsoft Word (DOS or Windows) or WordPerfect (DOS or Windows) files. A computer printout of the article should accompany the disk. Each anicle must be accompanied by an English abstract of 150 to 250 words, and between 10 and 30 English keywords

\section{Graphics}

One set of clear original drawings, tables, graphs, diagrams or quality prints thereof must be submitted. The locations of graphics must be clearly indicated in the text.

3. Bibliographical details and references in the text Examine recent issues of Lexikos for detaiłs. 


\title{
HINWEISE UND RICHTLINIEN FÜR AUTOREN
}

\author{
(Nehmen Sie bitte mit dem Büro des WAT Kontakt auf für eine ausführlichere Wiedergabe dieser Hinweise, \\ oder besuchen Sie unsere Webseite: http:/hwww.sun.ac.zatwavindex.htm)
}

\section{A. REDAKTIONELLE ZIELSETZUNGEN}

\section{Art und Inhalt der Artikel}

Es können Artikel aufgenommen werden, die sich mit Themen der Lexikographie befassen oder mit Zusammenhängen, die zwischen der Lexikographie und benachbarten Fachgebieten wie z.B. Linguistik, allgemeiner Sprachwissenschaft, Lexikologie, Computerwissenschaft und Management bestehen.

Die Beiträge sollten einer der folgenden Kategorien entsprechen:

(1) Forschungsartikel, die grundlegend über neue Forschungsansätze und deren Ergebnisse berichten

(2) Kontemplative Artikel, die bestehende Forschungsergebnisse und andere Informationen selbstindig, interpretativ, vergleichend oder kritisch bewertend wiedergeben.

(3) Rezensionsartikel, die in der Form eines Forschungsartikels eine oder mehrere veröffentlichten wissenschaftlichen Quellen kritisch rezenzieren.

Beiträge in Kategorien (1)-(3) werden streng anonym von unabhängigen wissenschaftlichen Experten begutachtet, um ein internationales fachliches Niveau in Lexikos zu gewährleisten.

(4) Rezensionen, die veröffentlichte wissenschaftliche Quellen und Produkte, wie z.B. Bücher und Software, analysieren und kritisch bewerten.

(5) Lexikographische Projekte, die vorgestellt werden

(6) Lexkovaria, die unterschiedliche Beiträge, Ankündigungen, praxisbezogene Informationen und Presseminteilungen lexikographischer Vereinigungen, die dem praktischen Lexikographen wichtig sein können, einschlieBen.

(7) Berichte über Konferenzen und Workshops.

Beiträge in Kategorien (4)-(7) müssen im akadernischen Stil abgefaßt werden. Sie werden von der Redaktion unter diesem Gesichtspunkt beurteilt.

\section{Wissenschaftliche Standards und das Beurtellungsver- Fahren}

Das Erziehungsministerium der südafrikanischen Regierung hat Lexikos als eine subventionierte, d.h. einkommenerzeugende Forschungszeitschift anerkannt.

Artikel werdes auf Grund der folgenden Gesichtspunkte bewertet: Sprache und Stil: Sachlichkeit und Verständlichkeit; Problembeschreibung. Argumentation und Schlußfolgerung; Hinweise auf die neueste und wichtigste Literatur; wesentlicher Beitrag zum besonderen Fachgebiet.

3. Sprache der Beiträge

Afrikaans, Deutsch, Englisch, Französisch oder Niederländisch.

\section{Das Urheberrecht}

Weder das Büro des WAT noch die African Association for Lexicography (AFRILEX) libernehmen Verantwortung für Anspriche, die daraus entstehen könnten, daß Autoren Material aus anderen Quellen benutzt haben.
Das Utheberrecht aller in Lexikos publizienen Artike! wird dem Aufsichtsrat unseres Büros übertragen. Es steht Autoren jedoch frei, ihren Beitrag anderweitig zu verwenden, vorausgesetzi, Lexikos (AFRILEX-Serie) wird ats Originalquelle genannt.

\section{Originalität}

Nur Originalbeiträge werden begutachtet. Autoren tragen die volle Verantwortung für die Originalität und den sachlichen Inhalt ihrer Beiträge.

\section{Sonderdrucke und Freiexemplare}

Autoren erhalten fünf Sonderdrucke ihrer veröffentlichten Forschungsartikel, kontemplativen Artikel oder Rezensions. artikel gratis sowie ein Freiexemplar der betreffenden Ausgabe. Rezensenten und Autoren von Beiträgen zu den Kategorien Lexikovaria, Projekte und Berichte erhalten fünf Sonderdrucke ihrer Beitráge gratis. Die Redaktion kann sich jedoch, abhängig von der Art und dem Umfang der Beiträge der letztgenannten vier Kategorien, vorbehalten, dem Autor ein Frejexemplar der Ausgabe zu überlassen.

\section{Einladung und redaktionelle Adresse}

Alle Autoren, die interessier sind, Beiträge filr Lexikos zu liefern, sind herzlich willkommen. Sie werden gebeten, ihre Artikel an die folgende Adresse zu schicken:

Der Redakteur

LEXIKOS

Buro van die WAT

Postfach 245

7599 STELLENBOSCH

Republik Suldafrika

\section{B. VORBEREITUNG DES MANUSKRIPTS}

Ein Arikelmanuskript muB den folgenden redaktionellen Anforderungen entsprectien:

\section{Umfang und Format}

Beiträge sollen nicht länger als 20 getippte A4-Seiten in zweizeiligem Abstand und mit Randabständen von ca. 2,5 $\mathrm{cm}$ sein. Das Manuskript sollte moglichst als elektronischer Text auf einer ( $360 \mathrm{~KB}$ bis $1.44 \mathrm{MB}$ ) Diskette vorgelegt werden, entweder im ASCIl-Format, oder in formatiertem Microsoft Word (DOS oder Windows) bzw. WordPerfect (DOS oder Windows). Eìn Ausdruck des vollständig formatierten Artikels soll mit der Diskette eingereicht werden Jedem Artikel ist eine Zusammenfassung im Umfang von 150-250 Wortern beizufügen. Ferner sollen etwa 10-30 inhaltskennzeichnende Stichworrer $z u$ jedem Artikel angegeben werden.

\section{Abbildungen}

Ein reproduktionsfähiger Satz der originalen Abbildungen, Illustrationen. Tabellen, Graphiken und Diagramme oder Qualitatsabdrucke muß vorgelegt werden. Der Text selber sollte klare Hinweise auf die Position der Abbildungen enthalten.

3. Bibliographische Einzelheiten und Hinweise im Text Zu Einzelheiten des bibliographischen Systems sind neuere Ausgaben von Lexikos einzusehen. 
http://lexikos.journals.ac.za/ 